\title{
NIST NCSTAR 1-3
}

Federal Building and Fire Safety Investigation of the World Trade Center Disaster

\section{Mechanical and Metallurgical Analysis of Structural Steel}

Frank W. Gayle

Richard J. Fields

William E. Luecke

Stephen W. Banovic

Timothy Foecke

Christopher N. McCowan

Thomas A. Siewert

J. David McColskey 


\section{Federal Building and Fire Safety Investigation of the World Trade Center Disaster}

\section{Mechanical and Metallurgical Analysis of Structural Steel}

Frank W. Gayle

Richard J. Fields

William E. Luecke

Stephen W. Banovic

Timothy Foecke

Christopher N. McCowan

Thomas A. Siewert

J. David McColskey

Materials Science and Engineering Laboratory

National Institute of Standards and Technology

September 2005

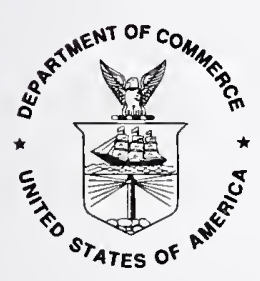

U.S. Department of Commerce

Carlos M. Gutierrez, Secretary

Technology Administration

Michelle O'Neill, Acting Under Secretary for Technology

National Institute of Standards and Technology

William Jeffrey, Director 


\section{Disclaimer No. 1}

Certain commercial entities, equipment, products, or materials are identified in this document in order to describe a procedure or concept adequately or to trace the history of the procedures and practices used. Such identification is not intended to imply recommendation, endorsement, or implication that the entities, products, materials, or equipment are necessarily the best available for the purpose. Nor does such identification imply a finding of fault or negligence by the National Institute of Standards and Technology.

\section{Disclaimer No. 2}

The policy of NIST is to use the International System of Units (metric units) in all publications. In this document, however, units are presented in metric units or the inch-pound system, whichever is prevalent in the discipline.

\section{Disclaimer No. 3}

Pursuant to section 7 of the National Construction Safety Team Act, the NIST Director has determined that certain evidence received by NIST in the course of this Investigation is "voluntarily provided safety-related information" that is "not directly related to the building failure being investigated" and that "disclosure of that information would inhibit the voluntary provision of that type of information" (15 USC 7306c).

In addition, a substantial portion of the evidence collected by NIST in the course of the Investigation has been provided to NIST under nondisclosure agreements.

\section{Disclaimer No. 4}

NIST takes no position as to whether the design or construction of a WTC building was compliant with any code since, due to the destruction of the WTC buildings, NIST could not verify the actual (or as-built) construction, the properties and condition of the materials used, or changes to the original construction made over the life of the buildings. In addition, NIST could not verify the interpretations of codes used by applicable authorities in determining compliance when implementing building codes. Where an Investigation report states whether a system was designed or installed as required by a code provision, NIST has documentary or anecdotal evidence indicating whether the requirement was met, or NIST has independently conducted tests or analyses indicating whether the requirement was met.

\section{Use in Legal Proceedings}

No part of any report resulting from a NIST investigation into a structural failure or from an investigation under the National Construction Safety Team Act may be used in any suit or action for damages arising out of any matter mentioned in such report (15 USC 281a; as amended by P.L. 107-231).

National Institute of Standards and Technology National Construction Safety Team Act Report 1-3 Natl. Inst. Stand. Technol. Natl. Constr. Sfty. Tm. Act Rpt. 1-3, 184 pages (September 2005) CODEN: NSPUE2

\section{U.S. GOVERNMENT PRINTING OFFICE WASHINGTON: 2005}

For sale by the Superintendent of Documents, U.S. Government Printing Office Internet: bookstore.gpo.gov — Phone: (202) 512-1800 - Fax: (202) 512-2250 Mail: Stop SSOP, Washington, DC 20402-0001 


\section{ABSTRACT}

This report is an overview of the results of the mechanical and metallurgical analysis of structural stecl from the World Trade Center (WTC), part of the National Institute of Standards and Technology Investigation of the WTC disaster of September 11, 2001.

The goal of the study was threefold:

Determine mechanical properties of WTC structural steel,

Determine the quality of the steel and if design requirements were met, and

Analyze the recovered steel to provide insight into failurc mechanisms to guide and/or validate models of building performance.

Structural steel recovered from the WTC site was analyzed for composition, microstructure, and mechanical properties, including room temperature properties (for modeling baseline building performance), high temperature properties (for modeling structural response of the building to fire), and behavior at high strain rates (for modeling airplane impact). Failure analysis of the recovered steel, complemented by pre-collapse photographs of the damaged building, was used to establish failure modes and temperature excursions experienced by the steel. In addition, documents from the construction era covering issues ranging from steel specifications to engineering design drawings were used to help interpret the results and supplement models of mechanical properties used in the models of building performance.

The analysis focused on the WTC 1 and WTC 2. Although no steel was recovered from WTC 7, a 47-story building that also collapsed on September 11, properties for steel used in its construction were estimated based on literature and contemporaneous documents.

Keywords: Failure analysis, mechanical properties, specifications, structural steel, World Trade Center. 
This page intentionally left blank. 


\section{TABLE OF CONTENTS}

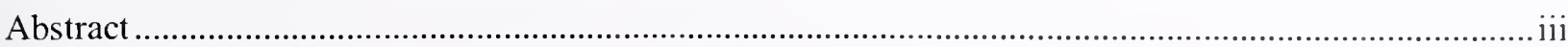

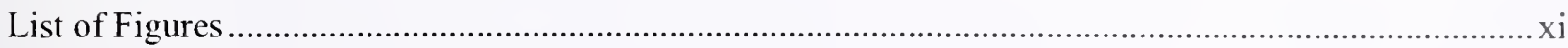

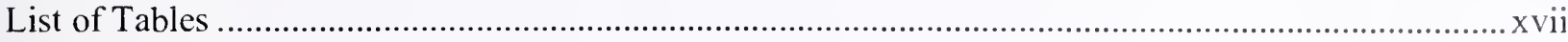

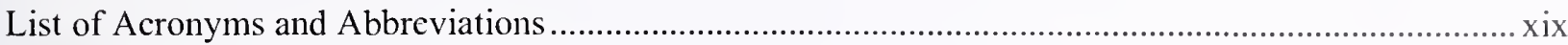

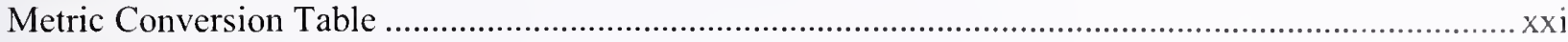

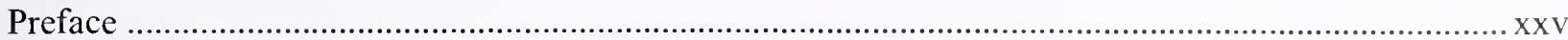

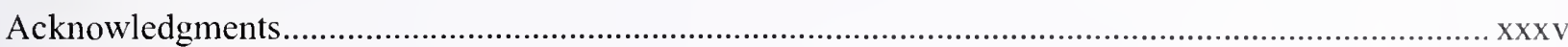

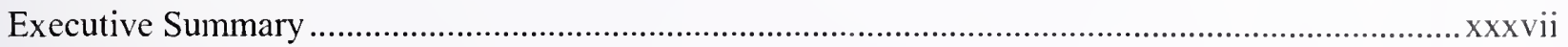

Chapter 1

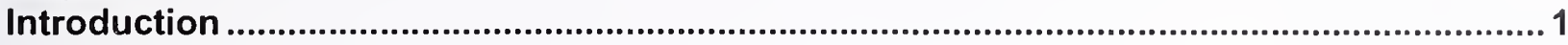

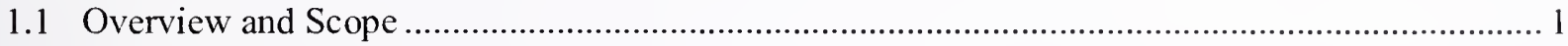

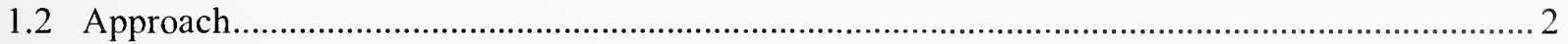

\section{Chapter 2}

Tower Design - Structural Steel Documents .............................................................................5

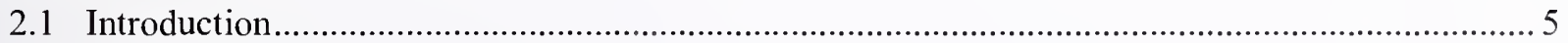

2.2 Specification of Steel Grades (Minimum Yield Strength) .................................................. 5

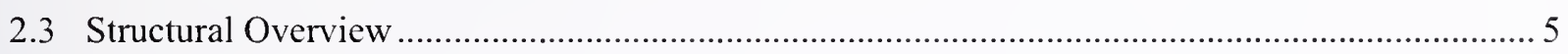

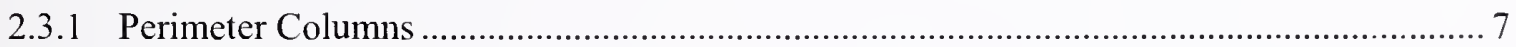

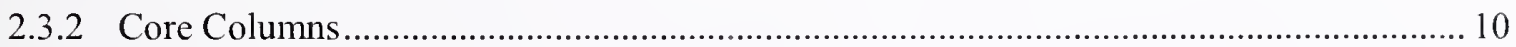

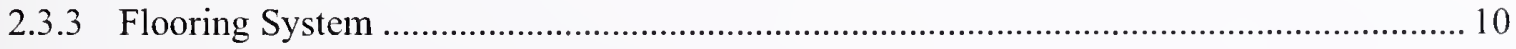

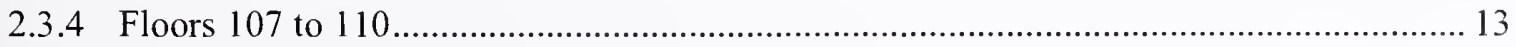

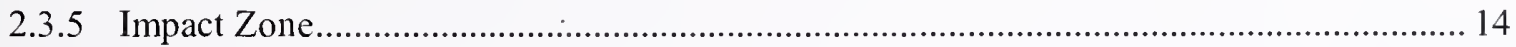

2.3.6 Floors Involved in Post-Impact Fires …..................................................................... 14

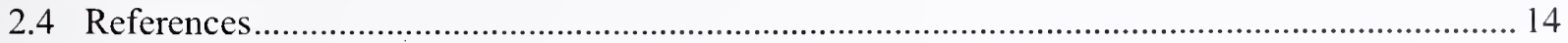

\section{Chapter 3}

Contemporaneous Steel Specifications ................................................................................ 15

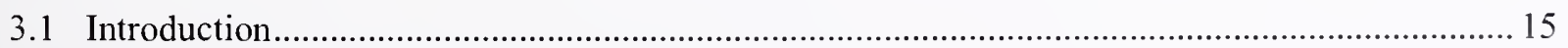

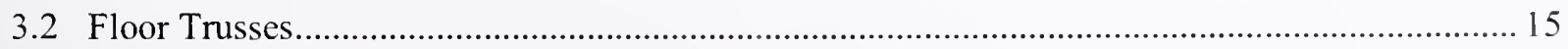

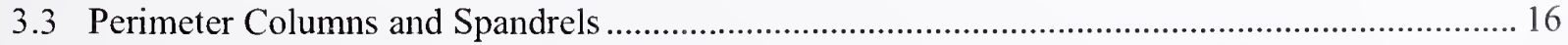

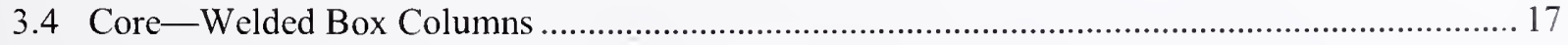




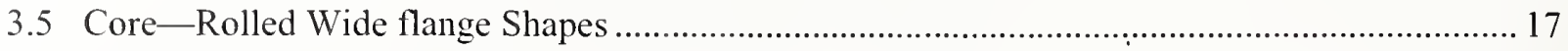

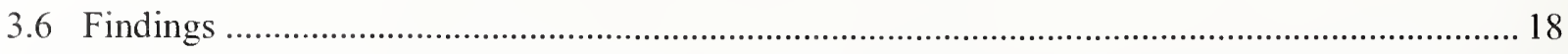

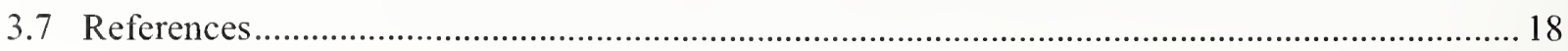

\section{Chapter 4}

Contemporaneous Construction Specifications

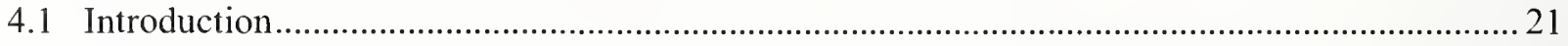

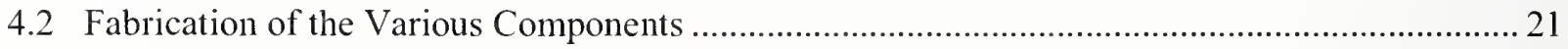

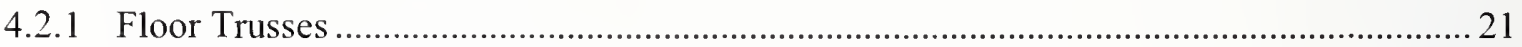

4.2.2 Exterior Wall Columns and Spandrels .................................................................. 21

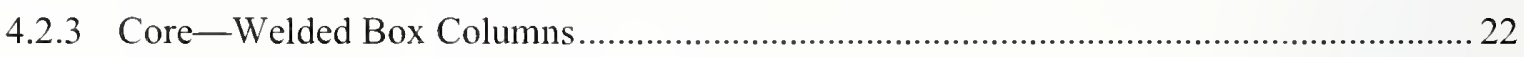

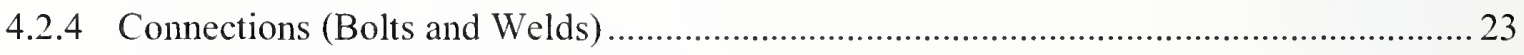

4.2.5 Construction (On-Site Assembly) ................................................................. 23

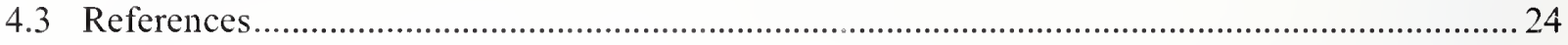

\section{Chapter 5}

Steel Inventory and Identification ..................................................................... 27

5.1 The Recovery of World Trade Center Structural Steel ........................................................ 27

5.2 Structural Elements Recovered from WTC Buildings........................................................ 28

5.2.1 Location and Labeling of Structural Steel Elements .................................................. 28

5.2.2 Identification Methods of WTC Structural Steel Elements ........................................... 29

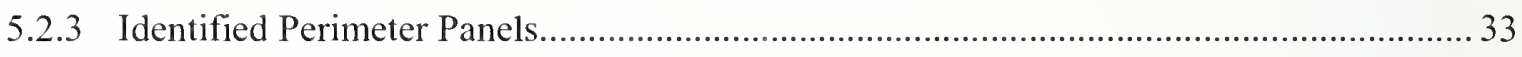

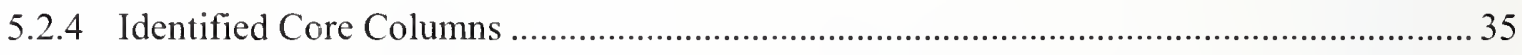

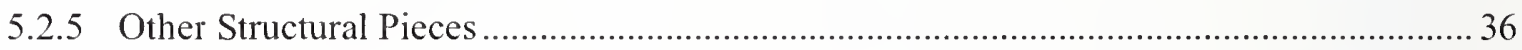

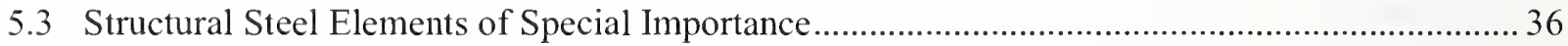

5.3.1 Samples Located in or around the Floors of the Airplane Impact ................................... 36

5.3.2 Samples Representing the Various Types of Steel Specified in the Design Drawings ...... 38

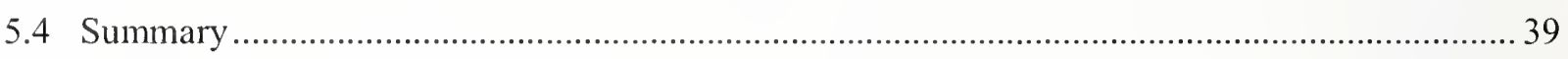

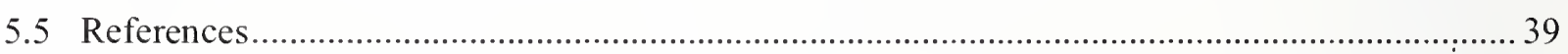

\section{Chapter 6}

Damage and Failure Analysis of Structural Steel

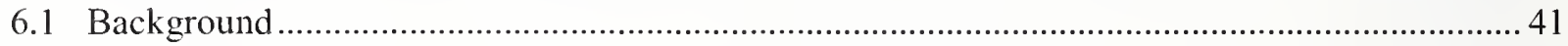

6.2 Observable Pre-Collapse Damage of Exterior Column Panels ............................................... 42

6.2.1 Photographic Analysis of Pre-Collapse Damage to Exterior Panels ............................... 42

6.2.2 Photographic Evidence of Damage to the Flooring System of WTC 2 .......................... 45

6.2.3 Damage to Sprayed Fire Resistive Material in WTC 1 ............................................ 45 
6.2.4 Damage to Spraycd Fire-Resistive Matcrial in WTC 2

6.2.5 Photographic Analysis of Prc-Collapse Firc Exposurc to Extcrior Panels

6.2.6 Photographic Evidence of Pre-Collapsc Distortion of Exterior Wall: South Facc of WTC 1

6.2.7 Photographic Evidence of Pre-Collapsc Distortion of Exterior Walls: East Face of WTC 2

6.2.8 Photographic Evidence of Details of the Collapse of WTC 2 .................................. 63

6.3 Physical Damage of Recovered Exterior Wall Panels

6.3.1 Overall Damage Patterns of Exterior Wall Panel Sections .......................................... 70

6.3.2 Damage and Failure Modes of Exterior Wall Columns ........................................... 70

6.3.3 Exterior Wall Spandrel Connections ....................................................................... 74

6.3.4 Exterior Wall Column Splices (End Plate/Butt Plate Connections) .............................. 74

6.3.5 Exterior Wall Seats or Floor Truss Conncctors...................................................... 80

6.4 Physical Damage of Core Elcments (Columns and Channels) .............................................. 80

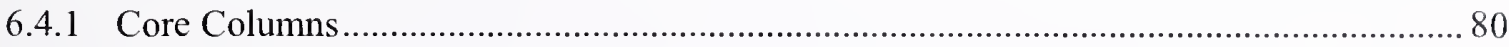

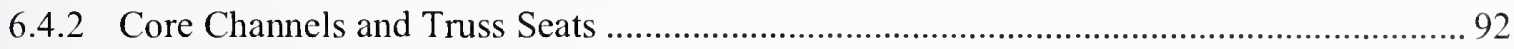

6.5 Physical Damage of Floor Truss Material ........................................................................ 93

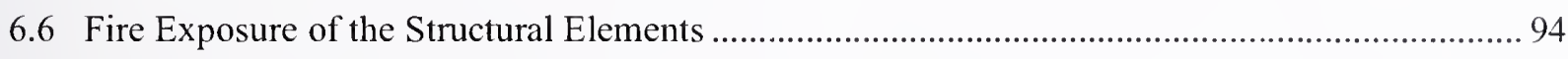

6.6.1 Visual Inspection of Recovered Structural Components............................................ 94

6.6.2 Core Columns Exposed to Fire ............................................................................. 95

6.6.3 Metallographic Analysis of Elements Exposed to Fire .................................................. 95

6.7 Comments Concerning Contract to Wiss, Janney, Elstner .................................................... 99

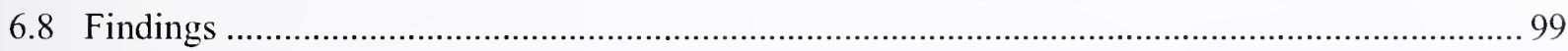

6.8.1 Structural Damage of Exterior Panel Sections ....................................................... 99

6.8.2 Structural Damage of Core Columns .................................................................. 100

6.8.3 Structural Damage of Floor Trusses and Seats........................................................... 100

6.8.4 Damage to Sprayed Fire-Resistive Material.............................................................. 100

6.8.5 Fire Exposure of Exterior Panel Sections................................................................ 101

6.8.6 Fire Exposure of Core Columns .......................................................................... 101

6.8.7 Time-Dependent Deformation of Perimeter Walls due to Fire and Load Redistribution .......................................................................................... 101

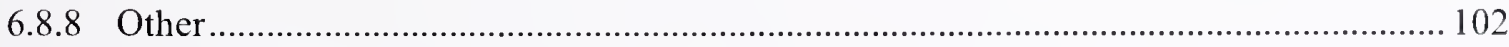

\section{Chapter 7}

Mechanical Properties of Structural Steels ............................................................... 103

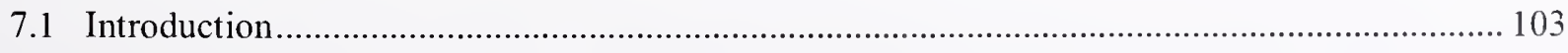




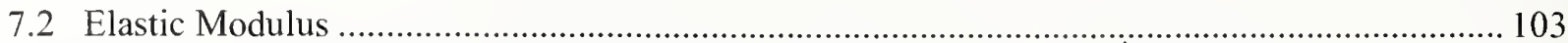

7.3 Room Temperature Tensile Properties ............................................................................. 104

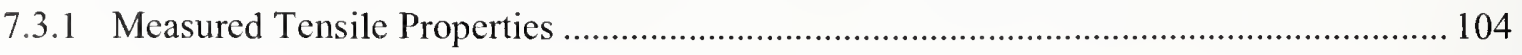

7.3.2 Measured Properties and Specifications ................................................................... 104

7.3.3 Representative Steel Stress-Strain Curves............................................................ 107

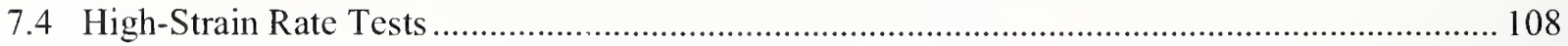

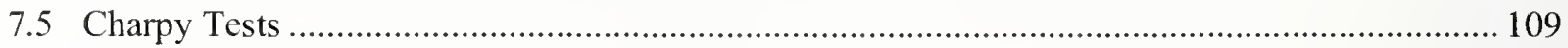

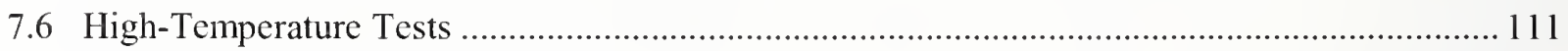

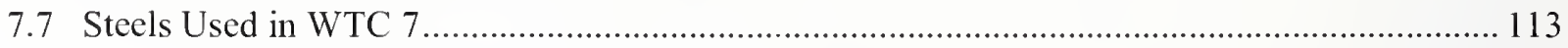

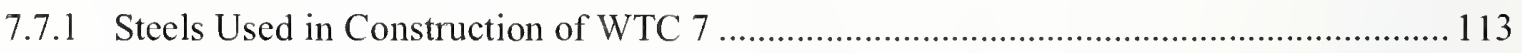

7.7.2 Mechanical Properties of WTC 7 Steel ................................................................. 114

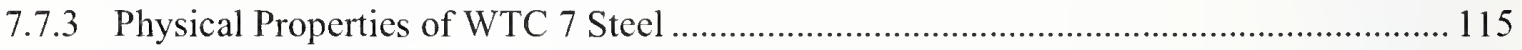

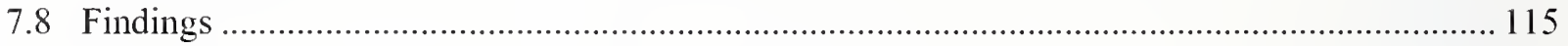

7.8.1 Room Temperature Tensile Properties ............................................................... 115

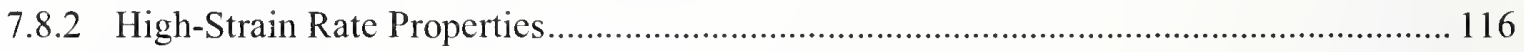

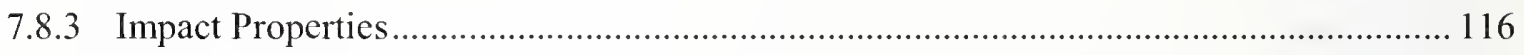

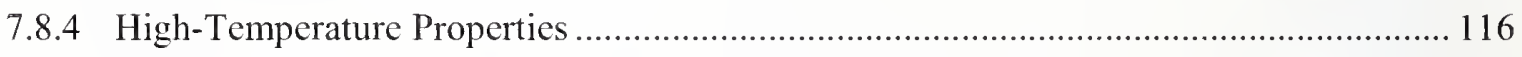

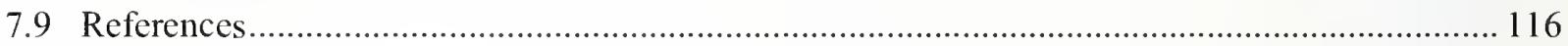

\section{Chapter 8}

Physical Properties of Structural Steels..................................................................... 119

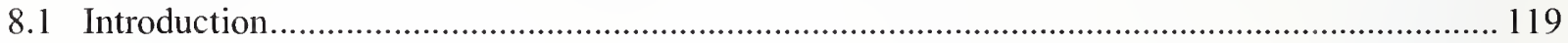

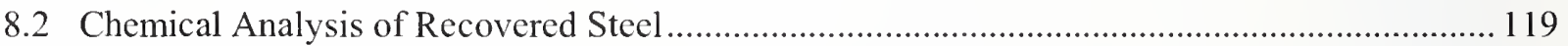

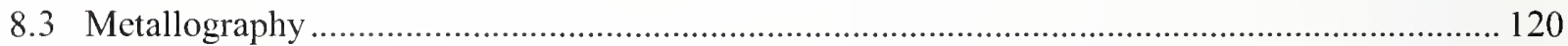

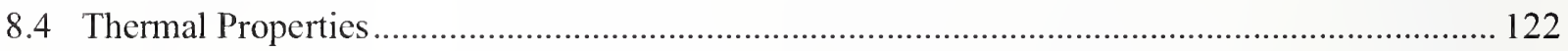

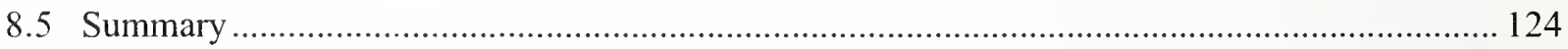

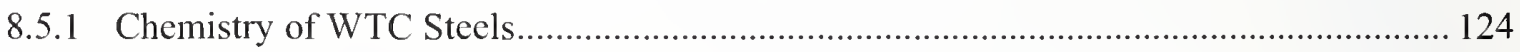

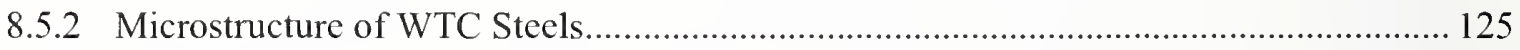

8.5.3 Thermal Property Values of WTC Steels .............................................................. 126

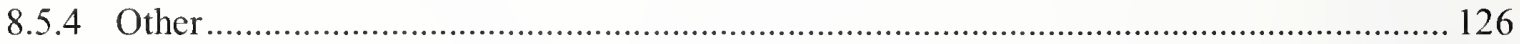

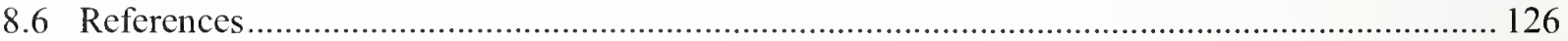

\section{Chapter 9}

Findings and Issues

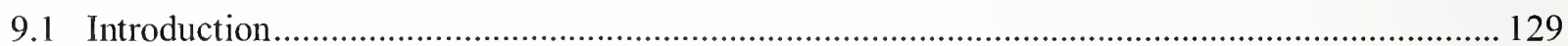

9.2 Findings - Steel Specifications, Standards, and Sources ................................................... 129 


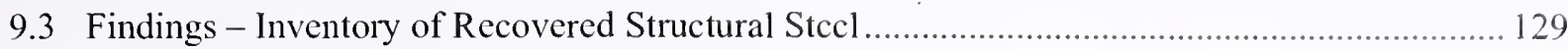

9.4 Findings - Damage and Failure Analysis ................................................................... 130

9.4.1 Structural Impact Damagc - Perimetcr Panels ......................................................... 130

9.4.2 Structural Impact Damage - Corc Columns ....................................................... 131

9.4.3 Impact Damagc to Sprayed Fire-Resistive Matcrial............................................... 131

9.4.4 Structural Damage - Floor Trusses and Seats …................................................ 131

9.4.5 Fire Exposure and Tcmperatures Reached by the Steel ......................................... 132

9.4.6 Time-Dependent Deformation of Perimetcr Walls Due to Fire and Load Redistribution

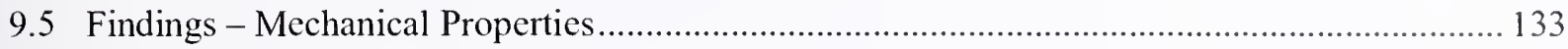

9.5.1 Room Temperature Tensile Properties .................................................................... 133

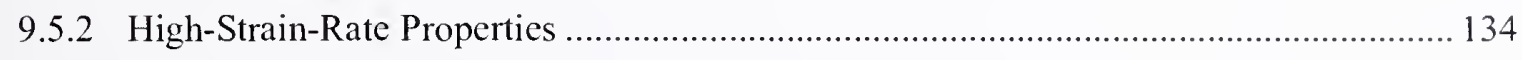

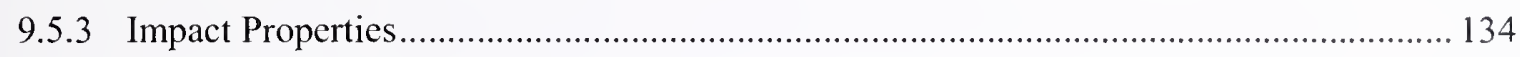

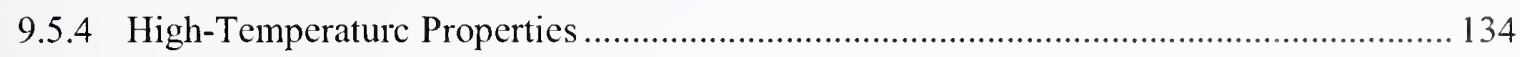

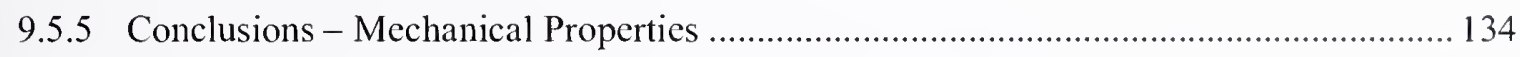

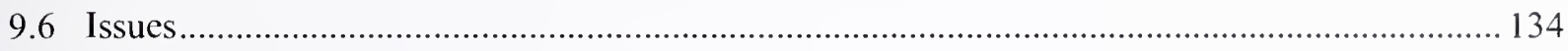


This page intentionally left blank. 


\section{LIST OF FIGURES}

Figure $\mathrm{P}-1$. The eight projects in the federal building and fire safety investigation of the WTC disaster.

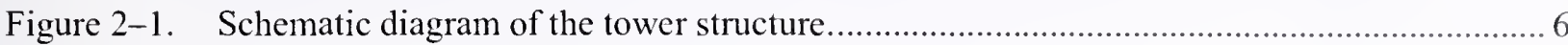

Figure 2-2. WTC 1 tower floor plan and column numbers........................................................... 7

Figure 2-3. Cross-section of perimeter columns; sections with and without spandrels........................ 8

Figure 2-4. Characteristic perimeter column panel consisting of three full columns connected by three spandrels.

Figure 2-5. Partial elevation of exterior bearing-wall frame showing exterior wall module construction. Highlighted panel is three stories tall (36 ft) and spans four floors.

Distance between panels has been exaggerated.

Figure 2-6. Core column layout in WTC towers.

Figure 2-7. Typical welded box members and rolled wide flange shapes used for core columns between floors 83 and 86 .

Figure 2-8. Schematic diagram of a floor truss.

Figure 2-9. Hat truss in upper floors.

Figure 5-1. Example of stampings on the interior base of the middle column for each panel. Shown here on panel M-10b are the stampings "B206 8683 ," indicating that it from WTC 2, column number 206, spanning floors 83 to 86 .

Figure 5-2. Example of stampings placed on one end of a core column. Shown here on sample C-90 are the stampings " 18 TON, $701 \mathrm{~B} 12-16,549$ WEST," indicating that it from WTC 2, core column number 701, and spans floors 12 to 16 . Also indicated are the approximate weight of the piece ( 18 tons) and the derrick division $<549>$ that was to lift it into place.

Figure 5-3. a) and b) Characteristic stenciling found on the lower portions of the exterior column panels for sample M-27. Markings indicate this piece was in WTC 1, column number 130, spanning floors 93 to 96 . Also seen are two other indicators, "5T" and " $<63>$," indicating the estimated piece weight in tons and erector's derrick division number, respectively. c) Characteristic stenciling found on core column for sample B-6152-1. Markings indicate this piece was in WTC 1, column number 803, spanning floors 15 to 18 with a derrick division number of $\langle 52\rangle$.

Figure 5-4. Location of the exterior panels recovered from the top third of the WTC towers. Recovered WTC 1 panels are shown in light shading/green and WTC 2 panels are in dark shading/blue. 
Figure 5-5a. Interpreted column damage, from photographic evidence, to north face of WTC 1, with overlay of recovered steel identified by NIST. Colored regions represent recovered portions. Both core columns ( $\# 603$ and $\# 605$ ) are in the second row from the north face of WTC 1.

Figure 5-5b. Interpreted column damage, from photographic evidence, to south face of WTC 2, with overlay of recovered steel identified by NIST. Samples shown represent recovered portions. Core column line 801 is in the row closest to the south face of WTC 2 .

Figure 6-1. (top) Enhanced image showing the impact hole in the north face of WTC 1, and (bottom) overlay of an outline of a Boeing 767 that has been distorted to get a best approximate fit with damage to WTC 1 . The location and type of localized damage has been indicated.

Figure 6-2. (top) Enhanced image showing the impact hole in the south face of WTC 2 and (bottom) overlay of the location and type of localized damage.

Figure 6-3. Damage to northeast corner of WTC 2 at 81 st floor. The red arrow indicates an intact column 300 at the $82 \mathrm{nd}$ floor. Other photographs confirm that the spandrel connecting column 300 to columns 259 and 301 is also intact (location indicated by green arrows).

Figure 6-4. Damage to columns on north face of WTC 2 near northeast corner due to internal impact by debris. Broken vertical column bolted connections (grcen arrows) are visible, along with an intact outer web on column 254 (red arrows) and missing column sections (blue arrows).

Figure 6-5. Dropped floors on north face of WTC 2.

Figure 6-6. Diagrams showing how the fireproofing was to be applied to the exterior columns, and the exterior aluminum panels were attached to the window frames.

Figure 6-7. Fireproofing that had been applied to the exterior columns. The depression formed by the outer web and the flange tips are completely filled in with fireproofing at the arrow. North face of WTC 2 .

Figure 6-8. Port side of impact hole in north face of WTC 1 showing missing fireproofing. The red arrows indicate a few of the many instances of missing fireproofing around the impact hole. The region roughly approximated as the area where the aluminum panels were dislodge has been digitally enhanced for clarity.

Figure 6-9. Missing fireproofing on floor trusses that fell into impact hole on north face of WTC 1. The arrows labeled "l" are three trusses where the lower or upper chords can be seen, and can distinguish the line that separates the two angle iron components. The arrows labeled " 2 " lie at either end of a lower chord of a truss that fell farther inside the building, and is made up of four angle irons (a double truss). The red paint color being visible and the fact that the line between the angle iron can be seen indicated that the fireproofing was displaced. 
Figure 6-10. Missing façade and fireproofing on north face of WTC 2. Two regions have had contrast and gamma adjusted to enhance visibility of the features. Red arrows indicate columns with missing or damaged fireproofing. Missing or damaged fireproofing determinations were made from this and several other photos taken at different times and angles. Blue arrows indicate white features where some sort of coating has preserved the fireproofing in place.

Figure 6-11. Missing fireproofing on flanges of exterior columns of north face of WTC 2.

Fireproofing has come off, revealing red Tnemec paint of the column (red arrows). This image also shows how the outer web regions have been partially or completely denuded of fireproofing. Damage is evidenced by shading by sunlight - compare green (undamaged fireproofing) and white (damaged fireproofing) arows. Blue arrow indicates same type of white coated area of fireproofing as previous figure that adhered when material above and below was dislodged.

Figure 6-12. Damage to fireproofing on east face of WTC 2 due to internal impact. Red arrows highlight areas where fireproofing has been damaged. The blowup to the right shows a column where the red Tnemec paint of the column is visible.

Figure 6-13. Time-fire exposure map for panel K-2 (A236: 92-95). Fire can be observed on the 92 nd and 94 th floors of the panel.

Figure 6-14. Inward bowing of south face (at right, with dark lines overdrawn) of WTC 1. Taken at 10:23 a.m. from an NYPD helicopter.

Figure 6-15. Pull in of south face of WTC 1 at 10:23 a.m. showing considerable displacements of outer columns into the building. Faint white vertical features are the aluminum façade of the exterior. Maximum visible inward displacement of the columns is 55 in. $+/-6$ in. Poor resolution leads to large uncertainties in measurements; a large fraction of the south face of the building is obscured by smoke.

Figure 6-16. East face of WTC 2 at 9:53:04 a.m. showing a larger amount of pull in. The vertical black lines were drawn to establish the original line of the exterior wall columns, and the shorter line segments are drawn at the same angle as the nearest observable joint in the exterior aluminum panels to establish the inward bowing distance. For actual column numbers, add a " 3 " to the front of the two-digit designations in the image.

Figure 6-17. Map of inward displacements of the east outer face of WTC 2 inward at 9:21:29 a.m. Each measurement refers to the upper left corner of the window within which the number resides. Measurements were in inches. The colors refer to groups of 5 in. displacements (0-5: black, 6-10: blue) for easier visualization.

Figure 6-18. Map of pull in displacements of the east outer face of WTC 2 inward shortly before collapse. Each measurement refers to the upper left corner of the window within which the number resides. Measurements were in inches. The colors refer to groups of 5 in. displacements (0-5: black, 6-10: blue, 11-15: orange, 16-20: red) for easier visualization. This data was combined from two images taken by the same photographer at nearly the same location $10 \mathrm{~s}$ apart, and it is assumed that the inward deflection did not change appreciably during this time.

Figure 6-19. Initial seconds of collapse of WTC 2 viewed from the east-northeast, and kink in the southeast edge of the building near the 106th floor (arrow). 
Figure 6-20. A close-up of the kink area in the previous figure (southeast corner, WTC 2), with overlaid lines to highlight the details of the kink geometry. The edge of the building (1) bends an angle to another direction (2), then bends back somewhat toward the original direction (3).

Figure 6-21. Northeast corner of WTC 2, several seconds before collapse. The corner shows no distortion of the type in the previous figure, implying that the distortion accompanied the collapse and did not precede it. The region in the upper right is enhanced for visibility.

Figure 6-22. a) Overall view of panel M-2 (A130: 94-97). Bottom of panel is on the left-hand side of the picture and the outside of the panel is facing down, b) major bend in panel located at the 97th floor level, and c) splayed bottoms of columns 129 and 130.

Figure 6-23. Thinning of outer web from column 130 of panel M-2 (A130: 96-99). a) Photograph showing thinning, b) graph indicating plate thinning near fracture surface.

Figure 6-24. Damage images from sample M-2 (A130: 96-99). a) Large buckles observed on the flange plates of column 130 , b) cracking of the flange plates on column 130 ,

c) cracking of spandrel at 97 th floor level, and d) no cracking of the welds in this area on column 130 .

Figure 6-25. Photographs of recovered spandrel connections from sample M-2 (A130: 96-99).

Figure 6-26. Photographs of recovered end plate connections from sample M-2 (A127: 97-100).

Both ends of column 131 had bolt failure that resulted in deformation of the bolt holes in the end plates.

Figure 6-27. Floor truss connectors for panel M-2 (A130: 96-99).

Figure 6-28a. Damage diagram overlaid with recovered samples and damage of connectors.....

Figure 6-28b. Damage of connectors. At or below the 95th floor, all connectors are either bent down or missing.

Figure 6-29a. Positioning of the recovered core columns with the core area for WTC 1. 86

Figure 6-29b. Positioning of the recovered core columns with the core area for WTC 2.

Figure 6-30. Core column C-80 (603A: 92-95). a) Overall view of recovered column, b) view of connection in the 92 nd floor region, failure as a result of bolt fracture, and c) torn end of column near the 94th floor region.

Figure 6-31. Overall view of recovered core columns C-88a (801B: 80-83) and C-88b (801B: 77-80).

Figure 6-32. Damage associated with core column C-88b (801B: 77-80). a) Overall view of failed end, b) bottoms of "south" flange and both webs bent towards the east just below the 80th floor level, ends were flame cut, and c) "north" flange bent towards the north, majority of plate was fractured with some flame cutting.....

Figure 6-33. Core column HH (605A: 98-101). a) Fracture at both ends and b) separation between flange and web in the 99 th floor region.

Figure 6-34. Failure modes of core channels. a) Fracture through channel as indicated by arrows, b) failure associated with end connector, and c) seat ripped off at welded connection to channel.

Figure 6-35. Examples of recovered floor truss material. a) Small sections of rod and chord (sample C-53) and b) "balled-up" sections of rod and chord (C-137f). 
Figure 6-36. Crushed portion of column 210 in the area of the 98 th floor (from sample K-1, A209: 97-100). Paint had mud cracking charactcristic in this region.

Figure 6-37. Spandrel at the 93rd floor of column 236 from samplc K-2 (A236: 92-95). Paint mud cracking was found below the 93rd floor line, no evidence of paint mud cracking was found above floor line.

Figure 6-38. Truss seat of the 99th floor on column 143 of samplc N-8 (A142: 97-100). a) Top view showing the re-solidified black plastic with cmbedded papers, most likely a binder of somc type and b) bottom view showing the drip pattern. It was unknown when the high-temperature excursion may have occurrcd.

Figure 7-1. Elastic modulus as a function of temperature determined by NIST compared with literature data for structural steel.

Figure 7-2. Examples of longitudinal (11, 12, and 13) and transverse (t1) room-temperaturc, strcssstrain curves for a $F_{y}=46 \mathrm{ksi}$ pcrimetcr column spandrel platc.

Figure 7-3. Ratio of measured yield strength or yield point to specified minimum yield point for WTC perimeter column steels.

Figure 7-4. Ratio of measured yield strength or yield point to specified minimum yield point for WTC core column steels.

Figure 7-5. Examples of representative true-stress true-strain curves for perimcter column steels. .... 108

Figure 7-6. Strain rate sensitivity as a function of specified minimum yield strength for WTC steels.

Figure 7-7. Summary data for Charpy tcsts. Lower figure: perimeter column steels; upper figure: core column steels.

Figure 7-8. Normalized yield strength as a function of temperature for WTC steels, the recommended function to describe behavior (solid line), and the literature data used to develop that relation.

Figure 7-9. Normalized tensile strength as a function of temperature for WTC stecls, the recommended function to describe behavior (solid line), and the literature data used to develop that relation.

Figure 7-10. Typical high-temperature stress-strain curves for specimen $\mathrm{HH}$, a $F_{y}=42 \mathrm{ksi}$ wideflange shape from near the fire and impact zone of WTC 1.

Figure 7-11. Typical creep curves for different stresses at $600{ }^{\circ} \mathrm{C}$ from truss steels specified as A 242, from specimen C132-TA.

Figure 8-1. Microstructure of ferritic-pearlitic WTC perimeter column flange plate steels. a) $F_{y}=$ $45 \mathrm{ksi}$ (unidentified perimeter column with " 45 " flange stamping) and b) $F_{y}=60 \mathrm{ksi}$ (WTC 1 , column 126, 97th floor).

Figurc 8-2. Examples of "quenched and tempered" WTC perimeter column flange steel. a) $F_{y}=$ $70 \mathrm{ksi}$ (WTC 1, column 224, 94th floor) and b) $F_{y}=80 \mathrm{ksi}$ (WTC 1, column 207, 89th floor).

Figure 8-3. Thermal conductivity as a function of temperature for twelve low-alloy steels 
This page left intentionally blank. 


\section{LIST OF TABLES}

Table P-1. Federal building and fire safety investigation of the WTC disaster............................. Xxvi

Table P-2. Public meetings and briefings of the WTC Investigation.

Table 3-1. Steel companies involved in WTC construction and their contracts. 16

Table 5-1. Identified perimeter column panel pieces from WTC 1 and WTC 2 33

Table 5-2. Identified pieces of core column material from WTC 1 and WTC 2 35

Table 6-1. Recovered exterior panel sections with known as-built locations, separated by precollapse location and environmental conditions.

Table 6-2. Recovered core columns with known as-built locations, separated by pre-collapse conditions. 
This page intentionally left blank. 


\section{LIST OF ACRONYMS AND ABBREVIATIONS}

\section{Acronyms}

AISC American Institute of Steel Construction

ASCE American Society of Civil Engineers

ASTM ASTM International

AWS American Welding Society

CTE coefficient of thermal expansion

DTAP dissemination and technical assistance program

FEMA Federal Emergency Management Agency

GMS Gilsanz Murray Steficek, LLP

HAZ heat affected zone

HSLA high-strength, low-alloy

JFK John F. Kennedy International Airport

LERA Leslie E. Robertson Associates

NCST National Construction Safety Team

NIST National Institute of Standards and Technology

NYPD New York City Police Department

PANYNJ Port Authority of New York and New Jersey

PC\&F Pacific Car and Foundry

PONYA Port of New York Authority

R\&D research and development

SEAoNY Structural Engineers Association of New York

SFRM sprayed fire-resistive materials

SHCR Skilling, Helle, Christiansen, \& Robertson

SMA shielded metal arc

USC United States Code

WJE Wiss, Janney, Elstner Associates, Inc.

WTC World Trade Center

WTC $1 \quad$ World Trade Center 1 (North Tower) 
$\begin{array}{ll}\text { WTC } 2 & \text { World Trade Center } 2 \text { (South Tower) } \\ \text { WTC } 7 & \text { World Trade Center } 7\end{array}$

\section{Abbreviations}

$\begin{array}{ll} \pm & \text { plus or minus } \\ { }^{\circ} \mathrm{C} & \text { degrees Celsius } \\ { }^{\circ} \mathrm{F} & \text { dcgrees Fahrenheit } \\ \mu \mathrm{m} & \text { micrometer } \\ \mathrm{cm} & \text { centimeter } \\ \mathrm{Cr} & \text { chromium } \\ \mathrm{ft} & \text { foot } \\ F_{y} & \text { yield strength (AISC usage) } \\ \mathrm{h} & \text { hour } \\ \mathrm{in} . & \text { inch } \\ \mathrm{kg} & \text { kilogram } \\ \mathrm{kip} & \text { a force equal to 1,000 pounds } \\ \mathrm{ksi} & 1,000 \text { pounds per square inch } \\ \mathrm{L} & \text { liter } \\ \mathrm{Ib} & \text { pound } \\ \mathrm{m} & \text { meter } \\ \mathrm{m}{ }^{2} & \text { square meter } \\ \mathrm{mm} & \text { millimeter } \\ \mathrm{min} & \text { minute } \\ \mathrm{s} & \text { second } \\ & \end{array}$


To convert from

to

AREA AND SECOND MOMENT OF AREA

square foot $\left(\mathrm{ft}^{2}\right)$

square inch $\left(\mathrm{in.}^{2}\right)$

square inch $\left(\right.$ in. $\left.^{2}\right)$

\section{FORCE}

kilogram-force (kgf)

kilopond (kilogram-force) (kp)

kip (1 kip=1.000 lbf)

kip ( $1 \mathrm{kip}=1.000 \mathrm{lbf})$

pound-force (lbf)

\section{FORCE DIVIDED BY LENGTH}

pound-force per foot (lbf/ft)

pound-force per inch (lbf/in.)

\section{LENGTH}

foot $(\mathrm{ft})$

inch (in)

inch (in.)

micron $(\mathrm{m})$

\section{MASS and MOMENT OF INERTIA}

kilogram-force second squared per meter $\left(\mathrm{kgf} \cdot \mathrm{s}^{2} / \mathrm{m}\right)$

pound foot squared $\left(\mathrm{lb} \cdot \mathrm{ft}^{2}\right)$

pound inch squared $\left(\mathrm{lb} \cdot\right.$ in. $\left.^{2}\right)$

ton, metric $(\mathrm{t})$

ton, short $(2,000 \mathrm{lb})$

\section{MASS DIVIDED BY AREA}

pound per square foot $\left(\mathrm{lb} / \mathrm{ft}^{2}\right)$

pound per square inch

(not pound force) $\left(\mathrm{lb} / \mathrm{in} .{ }^{2}\right.$ )

\author{
square meter $\left(\mathrm{m}^{2}\right)$ \\ square meter $\left(\mathrm{m}^{2}\right)$ \\ square centimeter $\left(\mathrm{cm}^{2}\right)$
}

\author{
9.290304 E-02 \\ 6.4516 E-04 \\ $6.4516 \mathrm{E}+00$
}

$\begin{array}{ll}\text { newton }(\mathrm{N}) & 9.80665 \mathrm{E}+00 \\ \text { newton }(\mathrm{N}) & 9.80665 \mathrm{E}+00 \\ \text { newton }(\mathrm{N}) & 4.448222 \mathrm{E}+03 \\ \text { kilonewton }(\mathrm{kN}) & 4.448222 \mathrm{E}+00 \\ \text { newton }(\mathrm{N}) & 4.448222 \mathrm{E}+00\end{array}$

newton per meter $(\mathrm{N} / \mathrm{m})$

$1.459390 \mathrm{E}+01$

newton per meter $(\mathrm{N} / \mathrm{m})$

$1.751268 \mathrm{E}+02$

$3.048 \mathrm{E}-01$

$2.54 \mathrm{E}-02$

$2.54 \mathrm{E}+00$

$1.0 \mathrm{E}-06$

$\begin{array}{ll}\text { kilogram }(\mathrm{kg}) & 9.80665 \mathrm{E}+00 \\ \text { kilogram meter squared }\left(\mathrm{kg} \cdot \mathrm{m}^{2}\right) & 4.214011 \mathrm{E}-02 \\ \text { kilogram meter squared }\left(\mathrm{kg} \cdot \mathrm{m}^{2}\right) & 2.926397 \mathrm{E}-04 \\ \text { kilogram }(\mathrm{kg}) & 1.0 \mathrm{E}+03 \\ \text { kilogram }(\mathrm{kg}) & 9.071847 \mathrm{E}+02\end{array}$

kilogram per square meter $\left(\mathrm{kg} / \mathrm{m}^{2}\right) \quad 4.882428 \mathrm{E}+00$

kilogram per square meter $\left(\mathrm{kg} / \mathrm{m}^{2}\right) \quad 7.030696 \mathrm{E}+02$ 


\section{To convert from}

\section{MASS DIVIDED BY LENGTH}

pound per foot $(\mathrm{lb} / \mathrm{ft})$

pound per inch (lb/in.)

pound per yard (lb/yd) to

Multiply by

kilogram per meter $(\mathrm{kg} / \mathrm{m})$

$1.488164 \mathrm{E}+00$

kilogram per meter $(\mathrm{kg} / \mathrm{m})$

$1.785797 \mathrm{E}+01$

kilogram per meter $(\mathrm{kg} / \mathrm{m})$

\section{PRESSURE or STRESS (FORCE DIVIDED BY AREA)}

kilogram-force per square centimeter $\left(\mathrm{kgf} / \mathrm{cm}^{2}\right)$ pascal $(\mathrm{Pa})$

kilogram-force per square meter $\left(\mathrm{kgf} / \mathrm{m}^{2}\right)$

pascal $(\mathrm{Pa})$

kilogram-force per square millimeter $\left(\mathrm{kgf} / \mathrm{mm}^{2}\right)$ pascal $(\mathrm{Pa})$

kip per square inch (ksi) (kip/in. $\left.{ }^{2}\right)$

kip per square inch (ksi) (kip/in. $\left.{ }^{2}\right)$

pascal $(\mathrm{Pa})$

kilopascal $(\mathrm{kPa})$

pound-force per square foot $\left(\mathrm{lbf} / \mathrm{ft}^{2}\right)$

pound-force per square inch (psi) (lbf/in. ${ }^{2}$ )

pound-force per square inch (psi) $\left(\mathrm{lbf} / \mathrm{in} .^{2}\right)$

psi (pound-force per square inch) $\left(\mathrm{lbf} / \mathrm{in} .^{2}\right)$

psi (pound-force per square inch) (lbf/in. $\left.{ }^{2}\right)$

\section{TEMPERATURE}

degree Celsius $\left({ }^{\circ} \mathrm{C}\right)$

degree centigrade

degree Fahrenheit $\left({ }^{\circ} \mathrm{F}\right)$

degree Fahrenheit $\left({ }^{\circ} \mathrm{F}\right)$

kelvin $(\mathrm{K})$

\section{TEMPERATURE INTERVAL}

degree Celsius $\left({ }^{\circ} \mathrm{C}\right)$

degree centigrade

degree Fahrenheit $\left({ }^{\circ} \mathrm{F}\right)$

degree Fahrenheit $\left({ }^{\circ} \mathrm{F}\right)$

degree Rankine $\left({ }^{\circ} \mathrm{R}\right)$ kelvin $(\mathrm{K})$

degree Celsius $\left({ }^{\circ} \mathrm{C}\right)$

degree Celsius $\left({ }^{\circ} \mathrm{C}\right)$

kelvin $(\mathrm{K})$

degree Celsius $\left({ }^{\circ} \mathrm{C}\right)$
$9.80665 \mathrm{E}+04$

$9.80665 \mathrm{E}+00$

$9.80665 \mathrm{E}+06$

$6.894757 \mathrm{E}+06$

$6.894757 \mathrm{E}+03$

$4.788026 \mathrm{E}+01$

$6.894757 \mathrm{E}+03$

$6.894757 \mathrm{E}+00$

$6.894757 \mathrm{E}+03$

$6.894757 \mathrm{E}+00$
$\mathrm{T} / \mathrm{K}=\mathrm{t} /{ }^{\circ} \mathrm{C}+273.15$

$\mathrm{t}^{\circ} \mathrm{C} \approx \mathrm{t} /$ deg. cent.

$\mathrm{t} /{ }^{\circ} \mathrm{C}=\left(\mathrm{t} /{ }^{\circ} \mathrm{F}-32\right) / 1.8$

$\mathrm{T} / \mathrm{K}=\left(\mathrm{t} /{ }^{\circ} \mathrm{F}+459.67\right) / 1.8$

$\mathrm{t}^{\circ} \mathrm{C}=\mathrm{T} / \mathrm{K} 2273.15$

1.0

1.0

$5.555556 \mathrm{E}-01$

$5.555556 \mathrm{E}-01$

$5.555556 \mathrm{E}-01$ 


\section{To convert from}

\section{VELOCITY (includes SPEED)}

foot per second ( $\mathrm{ft} / \mathrm{s}$ )

inch per second (in./s)

kilometer per hour $(\mathrm{km} / \mathrm{h})$

mile per hour $(\mathrm{mi} / \mathrm{h})$

mile per minute $(\mathrm{mi} / \mathrm{min})$

\section{VOLUME (includes CAPACITY)}

\author{
cubic foot $\left(\mathrm{ft}^{3}\right)$ \\ cubic inch $\left(\right.$ in. $\left.^{3}\right)$ \\ cubic yard $\left(\mathrm{yd}^{3}\right)$ \\ gallon (U.S.) (gal) \\ gallon (U.S.) (gal) \\ liter (L) \\ ounce (U.S. fluid) (fl oz) \\ ounce (U.S. fluid) (fl oz)
}

to

Multiply by

$\begin{array}{ll}\text { meter per second }(\mathrm{m} / \mathrm{s}) & 3.048 \mathrm{E}-01 \\ \text { meter per second }(\mathrm{m} / \mathrm{s}) & 2.54 \mathrm{E}-02 \\ \text { meter per second }(\mathrm{m} / \mathrm{s}) & 2.777778 \mathrm{E}-01 \\ \text { kilometer per hour }(\mathrm{km} / \mathrm{h}) & 1.609344 \mathrm{E}+00 \\ \text { meter per second }(\mathrm{m} / \mathrm{s}) & 2.68224 \mathrm{E}+01\end{array}$

cubic meter $\left(\mathrm{m}^{3}\right)$

2.831685 E-02

cubic meter $\left(\mathrm{m}^{3}\right)$

$1.638706 \mathrm{E}-05$

cubic meter $\left(\mathrm{m}^{3}\right)$

cubic meter $\left(\mathrm{m}^{3}\right)$

7.645549 E-01

3.785412 E-03

liter (L)

cubic meter $\left(\mathrm{m}^{3}\right)$

$3.785412 \mathrm{E}+00$

$1.0 \mathrm{E}-03$

cubic meter $\left(\mathrm{m}^{3}\right)$

milliliter $(\mathrm{mL})$
2.957353 E-05

$2.957353 \mathrm{E}+01$ 
This page intentionally left blank. 


\section{Preface}

\section{Genesis of This Investigation}

Immediately following the terrorist attack on the World Trade Center (WTC) on Scptcmber 11, 2001, the Federal Emergency Management Agcncy (FEMA) and the American Society of Civil Enginecrs began planning a building performance study of the disaster. The week of October 7, as soon as the rescue and scarch efforts ceascd, the Building Performance Study Team went to the sitc and began its assessment. This was to be a brief effort, as the study team consistcd of experts who largcly volunteercd their time away from their other professional commitments. The Building Performance Study Team issued its report in May 2002, fulfilling its goal "to determine probable failure mechanisms and to identify areas of future investigation that could lead to practical measures for improving the damage resistance of buildings against such unforeseen events."

On August 21, 2002, with funding from the U.S. Congress through FEMA, the National Institute of Standards and Technology (NIST) announced its building and fire safety investigation of the WTC disaster. On October 1, 2002, the National Construction Safety Team Act (Public Law 107-231), was signed into law. The NIST WTC Investigation was conducted under the authority of the National Construction Safety Team Act.

The goals of the investigation of the WTC disaster were:

- To investigate the building construction, the materials used, and the technical conditions that contributed to the outcome of the WTC disaster.

- To serve as the basis for:

- Improvements in the way buildings are designed, constructed, maintained, and used;

- Improved tools and guidance for industry and safety officials;

- Recommended revisions to current codes, standards, and practices; and

- Improved public safety.

The specific objectives were:

1. Determine why and how WTC 1 and WTC 2 collapsed following the initial impacts of the aircraft and why and how WTC 7 collapsed;

2. Determine why the injuries and fatalities were so high or low depending on location, including all technical aspects of fire protection, occupant behavior, evacuation, and emergency response;

3. Determine what procedures and practices were used in the design, construction, operation, and maintenance of WTC 1, 2, and 7; and

4. Identify, as specifically as possible, areas in current building and fire codes, standards, and practices that warrant revision. 
NIST is a nonregulatory agency of the U.S. Department of Commerce's Technology Administration. The purpose of NIST investigations is to improve the safety and structural integrity of buildings in the United States, and the focus is on fact finding. NIST investigative teams are authorized to assess building performance and emergency response and evacuation procedures in the wake of any building failure that has resulted in substantial loss of life or that posed significant potential of substantial loss of life. NIST does not have the statutory authority to make findings of fault nor negligence by individuals or organizations. Further, no part of any report resulting from a NIST investigation into a building failure or from an investigation under the National Construction Safety Team Act may be used in any suit or action for damages arising out of any matter mentioned in such report (15 USC 281a, as amended by Public Law 107-231).

\section{Organization of the Investigation}

The National Construction Safety Team for this Investigation, appointed by the then NIST Director, Dr. Arden L. Bement, Jr., was led by Dr. S. Shyam Sunder. Dr. William L. Grosshandler served as Associate Lead Investigator, Mr. Stephen A. Cauffman served as Program Manager for Administration, and Mr. Harold E. Nelson served on the team as a private sector expert. The Investigation included eight interdependent projects whose leaders comprised the remainder of the team. A detailed description of each of these eight projects is available at http:/wtc.nist.gov. The purpose of each project is summarized in Table $\mathrm{P}-1$, and the key interdependencies among the projects are illustrated in Fig. $\mathrm{P}-1$.

\section{Table P-1. Federal building and fire safety investigation of the WTC disaster.}

\section{Technical Area and Project Leader}

Analysis of Building and Fire Codes and Practices; Project Leaders: Dr. H. S. Lew and Mr. Richard W. Bukowski

Baseline Structural Performance and Aircraft Impact Damage Analysis; Project Leader: Dr. Fahim H. Sadek

Mechanical and Metallurgical Analysis of

Structural Steel; Project Leader: Dr. Frank W. Gayle

Investigation of Active Fire Protection

Systems; Project Leader: Dr. David D. Evans; Dr. William Grosshandler

Reconstruction of Thermal and Tenability Environment; Project Leader: Dr. Richard G. Gann

Structural Fire Response and Collapse Analysis; Project Leaders: Dr. John

L. Gross and Dr. Therese P. McAllister

Occupant Behavior, Egress, and Emergency

Communications; Project Leader: Mr. Jason D. Averill

Emergency Response Technologies and Guidelines; Project Leader: Mr. J. Randall Lawson

\section{Project Purpose}

Document and analyze the code provisions, procedures, and practices used in the design, construction, operation, and maintenance of the structural, passive fire protection, and emergency access and evacuation systems of WTC 1,2, and 7. Analyze the baseline performance of WTC 1 and WTC 2 under design, service, and abnormal loads, and aircraft impact damage on the structural, fire protection, and egress systems.

Determine and analyze the mechanical and metallurgical properties and quality of steel, weldments, and connections from steel recovered from WTC 1,2 , and 7 .

Investigate the performance of the active fire protection systems in WTC 1, 2, and 7 and their role in fire control, emergency response, and fate of occupants and responders.

Reconstruct the time-evolving temperature, thermal environment, and smoke movement in WTC 1,2, and 7 for use in evaluating the structural performance of the buildings and behavior and fate of occupants and responders.

Analyze the response of the WTC towers to fires with and without aircraft damage, the response of WTC 7 in fires, the performance of composite steel-trussed floor systems, and determine the most probable structural collapse sequence for WTC 1,2, and 7.

Analyze the behavior and fate of occupants and responders, both those who survived and those who did not, and the performance of the evacuation system.

Document the activities of the emergency responders from the time of the terrorist attacks on WTC 1 and WTC 2 until the collapse of WTC 7, including practices followed and technologies used. 


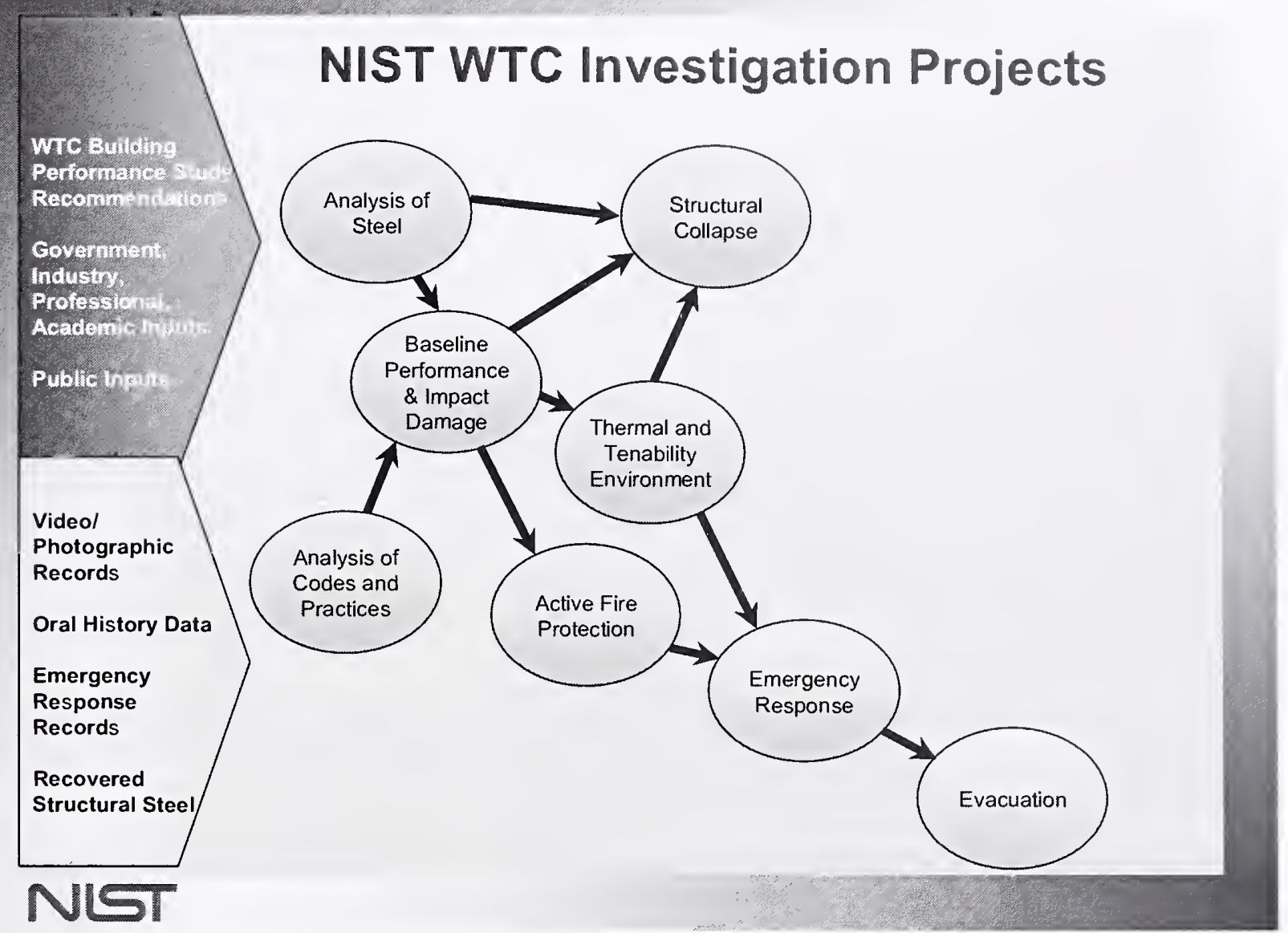

Figure P-1. The eight projects in the federal building and fire safety investigation of the WTC disaster.

\section{National Construction Safety Team Advisory Committee}

The NIST Director also established an advisory committee as mandated under the National Construction Safety Team Act. The initial members of the committee were appointed following a public solicitation. These were:

- Paul Fitzgerald, Executive Vice President (retired) FM Global, National Construction Safety Team Advisory Committee Chair

- John Barsom, President, Barsom Consulting, Ltd.

- John Bryan, Professor Emeritus, University of Maryland

- David Collins, President, The Preview Group, Inc.

- Glenn Corbett, Professor, John Jay College of Criminal Justice

- Philip DiNenno, President, Hughes Associates, Inc. 
- Robert Hanson, Professor Emeritus, University of Michigan

- Charles Thornton, Co-Chairman and Managing Principal, The Thornton-Tomasetti Group, Inc.

- Kathleen Tierney, Director, Natural Hazards Research and Applications Information Center, University of Colorado at Boulder

- Forman Williams, Director, Center for Energy Research, University of California at San Diego

This National Construction Safety Team Advisory Committee provided technical advice during the Investigation and commentary on drafts of the Investigation reports prior to their public release. NIST has benefited from the work of many people in the preparation of these reports, including the National Construction Safety Team Advisory Committee. The content of the reports and recommendations, however, are solely the responsibility of NIST.

\section{Public Outreach}

During the course of this Investigation, NIST held public briefings and meetings (listed in Table P-2) to solicit input from the public, present preliminary findings, and obtain comments on the direction and progress of the Investigation from the public and the Advisory Committee.

NIST maintained a publicly accessible Web site during this Investigation at http://wtc.nist.gov. The site contained extensive information on the background and progress of the Investigation.

\section{NIST's WTC Public-Private Response Plan}

The collapse of the WTC buildings has led to broad reexamination of how tall buildings are designed, constructed, maintained, and used, especially with regard to major events such as fires, natural disasters, and terrorist attacks. Reflecting the enhanced interest in effecting necessary change, NIST, with support from Congress and the Administration, has put in place a program, the goal of which is to develop and implement the standards, technology, and practices needed for cost-effective improvements to the safety and security of buildings and building occupants, including evacuation. emergency response procedures, and threat mitigation.

The strategy to meet this goal is a three-part NIST-led public-private response program that includes:

- A federal building and fire safety investigation to study the most probable factors that contributed to post-aircraft impact collapse of the WTC towers and the 47-story WTC 7 building, and the associated evacuation and emergency response experience.

- A research and development (R\&D) program to (a) facilitate the implementation of recommendations resulting from the WTC Investigation, and (b) provide the technical basis for cost-effective improvements to national building and fire codes, standards, and practices that enhance the safety of buildings, their occupants, and emergency responders. 
Table P-2. Public meetings and briefings of the WTC Investigation.

\begin{tabular}{|c|c|c|}
\hline Date & Location & Principal Agenda \\
\hline June 24,2002 & New York City, NY & $\begin{array}{l}\text { Public meeting: Public comments on the Drafi Plan for the } \\
\text { pending WTC Investigation. }\end{array}$ \\
\hline August 21,2002 & Gaithersburg, MD & Media briefing announcing the formal start of the Investigation. \\
\hline December 9,2002 & Washington, DC & $\begin{array}{l}\text { Media briefing on release of the Public Update and NIST request } \\
\text { for photographs and videos. }\end{array}$ \\
\hline April 8, 2003 & New York City, NY & $\begin{array}{l}\text { Joint public forum with Columbia University on first-person } \\
\text { interviews. }\end{array}$ \\
\hline April 29-30, 2003 & Gaithersburg, MD & $\begin{array}{l}\text { NCST Advisory Committee meeting on plan for and progress on } \\
\text { WTC Investigation with a public comment session. }\end{array}$ \\
\hline May 7,2003 & New York City, NY & Media briefing on release of May 2003 Progress Report. \\
\hline August 26-27, 2003 & Gaithersburg, MD & $\begin{array}{l}\text { NCST Advisory Committee meeting on status of the WTC } \\
\text { investigation with a public comment session. }\end{array}$ \\
\hline September 17,2003 & New York City, NY & $\begin{array}{l}\text { Media and public briefing on initiation of first-person data } \\
\text { collection projects. }\end{array}$ \\
\hline December 2-3, 2003 & Gaithersburg, MD & $\begin{array}{l}\text { NCST Advisory Committee meeting on status and initial results } \\
\text { and release of the Public Update with a public comment session. }\end{array}$ \\
\hline February 12, 2004 & New York City, NY & $\begin{array}{l}\text { Public meeting on progress and preliminary findings with public } \\
\text { comments on issues to be considered in formulating final } \\
\text { recommendations. }\end{array}$ \\
\hline June 18,2004 & New York City, NY & Media/public briefing on release of June 2004 Progress Report. \\
\hline June 22-23, 2004 & Gaithersburg, MD & $\begin{array}{l}\text { NCST Advisory Committee meeting on the status of and } \\
\text { preliminary findings from the WTC Investigation with a public } \\
\text { comment session. }\end{array}$ \\
\hline August 24,2004 & Northbrook, IL & $\begin{array}{l}\text { Public viewing of standard fire resistance test of WTC floor } \\
\text { system at Underwriters Laboratories, Inc. }\end{array}$ \\
\hline October 19-20,2004 & Gaithersburg, MD & $\begin{array}{l}\text { NCST Advisory Committee meeting on status and near complete } \\
\text { set of preliminary findings with a public comment session. }\end{array}$ \\
\hline November 22,2004 & Gaithersburg, MD & $\begin{array}{l}\text { NCST Advisory Committee discussion on draft annual report to } \\
\text { Congress, a public comment session, and a closed session to } \\
\text { discuss pre-draft recommendations for WTC Investigation. }\end{array}$ \\
\hline April 5, 2005 & New York City, NY & $\begin{array}{l}\text { Media and public briefing on release of the probable collapse } \\
\text { sequence for the WTC towers and draft reports for the projects on } \\
\text { codes and practices, evacuation, and emergency response. }\end{array}$ \\
\hline June 23,2005 & New York City, NY & $\begin{array}{l}\text { Media and public briefing on release of all draft reports for the } \\
\text { WTC towers and draft recommendations for public comment. }\end{array}$ \\
\hline $\begin{array}{l}\text { September 12-13, } \\
2005\end{array}$ & Gaithersburg, MD & $\begin{array}{l}\text { NCST Advisory Committee meeting on disposition of public } \\
\text { comments and update to draft reports for the WTC towers. }\end{array}$ \\
\hline $\begin{array}{l}\text { September 13-15, } \\
2005\end{array}$ & Gaithersburg, MD & $\begin{array}{l}\text { WTC Technical Conference for stakeholders and technical } \\
\text { community for dissemination of findings and recommendations } \\
\text { and opportunity for public to make technical comments. }\end{array}$ \\
\hline
\end{tabular}

- A dissemination and technical assistance program (DTAP) to (a) engage leaders of the construction and building community in ensuring timely adoption and widespread use of proposed changes to practices, standards, and codes resulting from the WTC Investigation and the R\&D program, and (b) provide practical guidance and tools to better prepare facility owners, contractors, architects, engineers, emergency responders, and regulatory authorities to respond to future disasters.

The desired outcomes are to make buildings, occupants, and first responders safer in future disaster events. 


\section{National Construction Safety Team Reports on the WTC Investigation}

A final report on the collapse of the WTC towers is being issued as NIST NCSTAR 1. A companion report on the collapse of WTC 7 is being issued as NIST NCSTAR 1A. The present report is one of a set that provides more detailed documentation of the Investigation findings and the means by which these technical results were achieved. As such, it is part of the archival record of this Investigation. The titles of the full set of Investigation publications are:

NIST (National Institute of Standards and Technology). 2005. Federal Building and Fire Safety Investigation of the World Trade Center Disaster: Final Report on the Collapse of the World Trade Center Towers. NIST NCSTAR 1. Gaithersburg, MD, September.

NIST (National Institute of Standards and Technology). 2006. Federal Brilding and Fire Safety Investigation of the World Trade Center Disaster: Final Report on the Collapse of World Trade Center 7. NIST NCSTAR 1A. Gaithersburg, MD.

Lew, H. S., R. W. Bukowski, and N. J. Carino. 2005. Federal Bnilding and Fire Safety Investigation of the World Trade Center Disaster: Design, Constrnction, and Maintenance of Structural and Life Safety Systems. NIST NCSTAR 1-1. National Institute of Standards and Technology. Gaithersburg, MD, September.

Fanella, D. A., A. T. Derecho, and S. K. Ghosh. 2005. Federal Building and Fire Safety Investigation of the World Trade Center Disaster: Design and Construction of Structural Systems. NIST NCSTAR 1-1A. National Institute of Standards and Technology. Gaithersburg, MD, September.

Ghosh, S. K., and X. Liang. 2005. Federal Building and Fire Safety Investigation of the World Trade Center Disaster: Comparison of Building Code Strnctural Requirements. NIST NCSTAR 1-1B. National Institute of Standards and Technology. Gaithersburg, MD, September.

Fanella, D. A., A. T. Derecho, and S. K. Ghosh. 2005. Federal Building and Fire Safety Investigation of the World Trade Center Disaster: Maintenance and Modifications to Structural Systems. NIST NCSTAR 1-1C. National Institute of Standards and Technology. Gaithersburg, MD, September.

Grill, R. A., and D. A. Johnson. 2005. Federal Building and Fire Safety Investigation of the World Trade Center Disaster: Fire Protection and Life Safety Provisions Applied to the Design and Construction of World Trade Center 1, 2, and 7 and Post-Constrnction Provisions Applied after Occupancy. NIST NCSTAR 1-1D. National Institute of Standards and Technology. Gaithersburg, MD, September.

Razza, J. C., and R. A. Grill. 2005. Federal Building and Fire Safety Investigation of the World Trade Center Disaster: Comparison of Codes, Standards, and Practices in Use at the Time of the Design and Construction of World Trade Center 1, 2, and 7. NIST NCSTAR 1-1E. National Institute of Standards and Technology. Gaithersburg, MD, September.

Grill, R. A., D. A. Johnson, and D. A. Fanella. 2005. Federal Building and Fire Safety Investigation of the World Trade Center Disaster: Comparison of the 1968 and Current (2003) New 
York City Bwilding Code Provisions. NIST NCSTAR 1-1F. National Institute of Standards and Technology. Gaithersburg, MD, Scptember.

Grill, R. A., and D. A. Johnson. 2005. Federal Building and Fire Safety Investigation of the World Trade Center Disaster: Amendments to the Fire Protection and Life Safety Provisions of the New York City Building Code by Local Laws Adopted While World Trade Center 1, 2, and 7 Were in Use. NIST NCSTAR 1-1G. National Institute of Standards and Technology. Gaithersburg, MD, September.

Grill, R. A., and D. A. Johnson. 2005. Federal Building and Fire Safety Investigation of the World Trade Center Disaster: Post-Construction Modifications to Fire Protection and Life Safety Systems of World Trade Center 1 and 2. NIST NCSTAR 1-1H. National Institute of Standards and Technology. Gaithersburg, MD, September.

Grill, R. A., D. A. Johnson, and D. A. Fanella. 2005. Federal Building and Fire Safety Investigation of the World Trade Center Disaster: Post-Constriction Modifications to Fire Protection, Life Safety, and Strictural Systems of World Trade Center 7. NIST NCSTAR 1-11. National Institute of Standards and Technology. Gaithersburg, MD, Scptember.

Grill, R. A., and D. A. Johnson. 2005. Federal Building and Fire Safety Investigation of the World Trade Center Disaster: Design, Installation, and Operation of Finel System for Energency Power in World Trade Center 7. NIST NCSTAR 1-1J. National Institute of Standards and Technology. Gaithersburg, MD, September.

Sadek, F. 2005. Federal Brilding and Fire Safety Investigation of the World Trade Center Disaster: Baseline Structural Performance and Aircraft Impact Dantage Analysis of the World Trade Center Towers. NIST NCSTAR 1-2. National Institute of Standards and Technology. Gaithersburg, MD, September.

Faschan, W. J., and R. B. Garlock. 2005. Federal Building and Fire Safety Investigation of the World Trade Center Disaster: Reference Structural Models and Baseline Performance Analysis of the World Trade Center Towers. NIST NCSTAR 1-2A. National Institute of Standards and Technology. Gaithersburg, MD, September.

Kirkpatrick, S. W., R. T. Bocchieri, F. Sadek, R. A. MacNeill, S. Holmes, B. D. Peterson, R. W. Cilke, C. Navarro. 2005. Federal Building and Fire Safety Investigation of the World Trade Center Disaster: Analysis of Aircraft Impacts into the World Trade Center Towers, NIST NCSTAR 1-2B. National Institute of Standards and Technology. Gaithersburg, MD, September.

Gayle, F. W., R. J. Fields, W. E. Luecke, S. W. Banovic, T. Foecke, C. N. McCowan, T. A. Siewert, and J. D. McColskey. 2005. Federal Building and Fire Safety Investigation of the World Trade Center Disaster: Mechanical and Metallirgical Analysis of Strnctmal Steel. NIST NCSTAR 1-3. National Institute of Standards and Technology. Gaithersburg, MD, September.

Luecke, W. E., T. A. Siewert, and F. W. Gayle. 2005. Federal Brilding and Fire Safety Investigation of the World Trade Center Disaster: Contemporaneons Structural Steel Specifications. NIST Special Publication 1-3A. National Institute of Standards and Technology. Gaithersburg, MD, September. 
Banovic, S. W. 2005. Federal Building and Fire Safety Investigation of the World Trade Center Disaster: Steel Inventory and Identification. NIST NCSTAR 1-3B. National Institute of Standards and Technology. Gaithersburg, MD, September.

Banovic, S. W., and T. Foecke. 2005. Federal Building and Fire Safety Investigation of the World Trade Center Disaster: Damage and Failure Modes of Structural Steel Components. NIST NCSTAR 1-3C. National Institute of Standards and Technology. Gaithersburg, MD, September.

Luecke, W. E., J. D. McColskey, C. N. McCowan, S. W. Banovic, R. J. Fields, T. Foecke, T. A. Siewert, and F. W. Gayle. 2005. Federal Building and Fire Safety Investigation of the World Trade Center Disaster: Mechanical Properties of Structural Steels. NIST NCSTAR 1-3D. National Institute of Standards and Technology. Gaithersburg, MD, September.

Banovic, S. W., C. N. McCowan, and W. E. Luecke. 2005. Federal Building and Fire Safety Investigation of the World Trade Center Disaster: Physical Properties of Structural Steels. NIST NCSTAR 1-3E. National Institute of Standards and Technology. Gaithersburg, MD, September.

Evans, D. D., R. D. Peacock, E. D. Kuligowski, W. S. Dols, and W. L. Grosshandler. 2005. Federal Building and Fire Safety Investigation of the World Trade Center Disaster: Active Fire Protection Systems. NIST NCSTAR 1-4. National Institute of Standards and Technology. Gaithersburg, MD, September.

Kuligowski, E. D., D. D. Evans, and R. D. Peacock. 2005. Federal Building and Fire Safety Investigation of the World Trade Center Disaster: Post-Construction Fires Prior to September 11, 2001. NIST NCSTAR 1-4A. National Institute of Standards and Teclnology. Gaithersburg, MD, September.

Hopkins, M., J. Schoenrock, and E. Budnick. 2005. Federal Building and Fire Safety Investigation of the World Trade Center Disaster: Fire Suppression Systems. NIST NCSTAR 1-4B. National Institute of Standards and Technology. Gaithersburg, MD, September.

Keough, R. J., and R. A. Grill. 2005. Federal Building and Fire Safety Investigation of the World Trade Center Disaster: Fire Alarm Systems. NIST NCSTAR 1-4C. National Institute of Standards and Technology. Gaithersburg, MD, September.

Ferreira, M. J., and S. M. Strege. 2005. Federal Building and Fire Safety Investigation of the World Trade Center Disaster: Smoke Management Systems. NIST NCSTAR 1-4D. National Institute of Standards and Technology. Gaithersburg, MD, September.

Gann, R. G., A. Hamins, K. B. McGrattan, G. W. Mulholland, H. E. Nelson, T. J. Ohlemiller, W. M. Pitts, and K. R. Prasad. 2005. Federal Building and Fire Safety Investigation of the World Trade Center Disaster: Reconstruction of the Fires in the World Trade Center Towers. NIST NCSTAR 1-5. National Institute of Standards and Technology. Gaithersburg, MD, September.

Pitts, W. M., K. M. Butler, and V. Junker. 2005. Federal Building and Fire Safety Investigation of the World Trade Center Disaster: Visual Evidence, Damage Estimates, and Timeline Analysis. NIST NCSTAR 1-5A. National Institute of Standards and Technology. Gaithersburg, MD, September. 
Hamins, A., A. Maranghides, K. B. McGrattan, E. Johnsson, T. J. Ohlemiller, M. Donnclly, J. Yang, G. Mulholland, K. R. Prasad, S. Kukuck, R. Anleitner and T. McAllister. 2005. Federal Building and Fire Safety Investigation of the World Trade Center Disaster: Experiments and Modeling of Structural Steel Elements Exposed to Fire. NIST NCSTAR 1-5B. National Institute of Standards and Technology. Gaithcrsburg, MD, Scptcmber.

Ohlemiller, T. J., G. W. Mulholland, A. Maranghides, J. J. Filliben, and R. G. Gann. 2005. Federal Building and Fire Safety Investigation of the World Trade Center Disaster: Fire Tests of Single Office Workstations. NIST NCSTAR 1-5C. National Institute of Standards and Tcchnology. Gaithersburg, MD, Septcmber.

Gann, R. G., M. A. Riley, J. M. Repp, A. S. Whittaker, A. M. Reinhorn, and P. A. Hough. 2005. Federal Building and Fire Safety Investigation of the World Trade Center Disaster: Reaction of Ceiling Tile Systems to Shocks. NIST NCSTAR 1-5D. National Institute of Standards and Technology. Gaithcrsburg, MD, September.

Hamins, A., A. Maranghides, K. B. McGrattan, T. J. Ohlemiller, and R. Anleitner. 2005. Federal Building and Fire Safety Investigation of the World Trade Center Disaster: Experiments and Modeling of Multiple Workstations Burning in a Compartment. NIST NCSTAR 1-5E. National Institute of Standards and Technology. Gaithersburg, MD, September.

McGrattan, K. B., C. Bouldin, and G. Forney. 2005. Federal Building and Fire Safety Investigation of the World Trade Center Disaster: Computer Simulation of the Fires in the World Trade Center Towers. NIST NCSTAR 1-5F. National Institute of Standards and Technology. Gaithersburg, MD, September.

Prasad, K. R., and H. R. Baum. 2005. Federal Building and Fire Safety Investigation of the World Trade Center Disaster: Fire Structure Interface and Thermal Response of the World Trade Center Towers. NIST NCSTAR 1-5G. National Institute of Standards and Technology. Gaithersburg, $\mathrm{MD}$, September.

Gross, J. L., and T. McAllistcr. 2005. Federal Building and Fire Safety Investigation of the World Trade Center Disaster: Structural Fire Response and Probable Collapse Sequence of the World Trade Center Towers. NIST NCSTAR 1-6. National Institute of Standards and Technology. Gaithersburg, MD, September.

Carino, N. J., M. A. Starnes, J. L. Gross, J. C. Yang, S. Kukuck, K. R. Prasad, and R. W. Bukowski. 2005. Federal Building and Fire Safety Investigation of the World Trade Center Disaster: Passive Fire Protection. NIST NCSTAR 1-6A. National Institute of Standards and Technology. Gaithersburg, MD, September.

Gross, J., F. Hervey, M. Izydorek. J. Mammoser, and J. Treadway. 2005. Federal Building aud Fire Safety Investigation of the World Trade Center Disaster: Fire Resistance Tests of Floor Truss Systems. NIST NCSTAR 1-6B. National Institute of Standards and Technology. Gaithersburg, MD, September.

Zarghamee, M. S., S. Bolourchi, D. W. Eggers, Ö. O. Erbay, F. W. Kan, Y. Kitane, A. A. Liepins, M. Mudlock, W. I. Naguib, R. P. Ojdrovic, A. T. Sarawit, P. R Barrett, J. L. Gross, and 
T. P. McAllister. 2005. Federal Building and Fire Safety Investigation of the World Trade Center Disaster: Conponent, Connection, and Subsystem Structural Analysis. NIST NCSTAR 1-6C. National Institute of Standards and Technology. Gaithersburg, MD, September.

Zarghamee, M. S., Y. Kitane, Ö. O. Erbay, T. P. McAllister, and J. L. Gross. 2005. Federal Building and Fire Safety Investigation of the World Trade Center Disaster: Global Structural Analysis of the Response of the World Trade Center Towers to Impact Damage and Fire. NIST NCSTAR 1-6D. National Institute of Standards and Technology. Gaithersburg, MD, September.

McAllister, T., R. W. Bukowski, R. G. Gann, J. L. Gross, K. B. McGrattan, H. E. Nelson, L. Phan, W. M. Pitts, K. R. Prasad, F. Sadek. 2006. Federal Building and Fire Safety Investigation of tlie World Trade Center Disaster: Structural Fire Response and Probable Collapse Sequence of World Trade Center 7. (Provisional). NIST NCSTAR 1-6E. National Institute of Standards and Technology. Gaithersburg, MD.

Gilsanz, R., V. Arbitrio, C. Anders, D. Chlebus, K. Ezzeldin, W. Guo, P. Moloney, A. Montalva, J. Oh, K. Rubenacker. 2006. Federal Building and Fire Safety Investigation of the World Trade Center Disaster: Structural Analysis of the Response of World Trade Center 7 to Debris Damage and Fire. (Provisional). NIST NCSTAR 1-6F. National Institute of Standards and Technology. Gaithersburg, MD.

Kim, W. 2006. Federal Building and Fire Safety Investigation of the World Trade Center Disaster: Analysis of Septenber 11, 2001, Seismogram Data. (Provisional). NIST NCSTAR 1-6G. National Institute of Standards and Technology. Gaithersburg, MD.

Nelson, K. 2006. Federal Building and Fire Safety Investigation of the World Trade Center Disaster: The Con Ed Substation in World Trade Center 7. (Provisional). NIST NCSTAR 1-6H. National Institute of Standards and Technology. Gaithersburg, MD.

Averill, J. D., D. S. Mileti, R. D. Peacock, E. D. Kuligowski, N. Groner, G. Proulx, P. A. Reneke, and H. E. Nelson. 2005. Federal Building and Fire Safety Investigation of the World Trade Center Disaster: Occupant Behavior, Egress, and Emergency Communication. NIST NCSTAR 1-7. National Institute of Standards and Technology. Gaithersburg, MD, September.

Fahy, R., and G. Proulx. 2005. Federal Building and Fire Safety Investigation of the World Trade Center Disaster: Analysis of Published Accounts of the World Trade Center Evacuation. NIST NCSTAR 1-7A. National Institute of Standards and Technology. Gaithersburg, MD, September.

Zmud, J. 2005. Federal Building and Fire Safety Investigation of the World Trade Center . Disaster: Technical Documentation for Survey Administration. NIST NCSTAR 1-7B. National Institute of Standards and Technology. Gaithersburg, MD, September.

Lawson, J. R., and R. L. Vettori. 2005. Federal Building and Fire Safety Investigation of the World Trade Center Disaster: The Emergency Response Operations. NIST NCSTAR 1-8. National Institute of Standards and Technology. Gaithersburg, MD, September. 


\section{ACKNOWLEDGMENTS}

The National Institute of Standards and Technology (NIST) thanks the many pcople who contributcd valuable skills, facilities, and information that made this report possible, including the following.

Maureen Williams, Kil-Won Moon, Rodney Jiggetts, Michael Savage, Donald Kramer, David Kclley, Deb Basak, Tessa Dvorak, Brian Goudy, Raymond Santoyo, Mark Iadicola, Lonn Rodinc, Don Harne, Jim Fink, Sandy Claggett, Carelyn Campbell, Richard Ricker, David Dayan, Paul Brand, Mike Kcnncdy, Greg Turk, John Sieber, and Michael Winchester, all of NIST, are thanked for numerous technical contributions.

Volunteers of the Structural Engineers Association of New York are thanked for their efforts in the steel recovery: Amit Bandyopadhyay, Anamaria Bonilla, Peter Chipchase, Anthony Chuliver, Edward DePaola, Louis Errichiello, James Fahey, Jeffrey Hartman, David Hoy, Dean Koutsoubis, Andew McConnell, Rajani Nair, Alan Rosa, Gary Steficek, Kevin Terry. Countless hours were unselfishly spent searching for these invaluable pieces that are an integral component of this investigation. Further. the following people are recognized for outstanding leadership roles in the recovery effort:

- Ramon Gilsanz, primary leader of the recovery effort

- David Sharp, coordinated volunteer activities; authored guide selection of suitable pieces

- Audrey Massa of the Federal Emergency Management Agency (FEMA), documentation and cataloguing of efforts and pieces to be saved.

The FEMA/American Society of Civil Engineers Building Performance Study team, Professor A. Astaneh-Asl (University of California, Berkeley), and the National Science Foundation are recognized for their help in the recovery effort; Blanford Land Development Corporation, Hugo Neu Schnitzer, Inc., and Metal Management, Inc., for their assistance and patience during the review, abatement, and removal of pieces of interest from the salvage yards; and the Port Authority of New York and New Jersey for its assistance in surveying, sectioning, and transporting the technically significant steel collected and stored at John F. Kennedy International Airport.

Dr. George Krauss (University Emeritus Professor, Colorado School of Mines), Dr. Elliot Brown (EB Consulting, Golden, CO), and Mr. Arlan O. Benscoter and Dr. Arnold R. Marder (Lehigh University), are recognized for technical discussions regarding the metallurgy of the steels in the World Trade Center (WTC) towers.

Professor Hugh MacGillivray (Imperial College, London, UK) and Professor David Matlock (Colorado School of Mines) are recognized for technical discussions regarding high strain rate testing, and Professor Matlock for use of the high-rate tensile testing machine at the Colorado School of Mines.

Dr. Amelia Logan and Dr. Edward P. Vicenzi of the National Museum of Natural History, Smithsonian Institution, are thanked for analytical examination of the corrosion products observed on the recovered WTC steel. 
Dr. Kazushige Tokuno (Nippon Steel USA) is recognized for supplying historical information on Yawata steel.

Former employees of Laclede Steel (St. Louis, Missouri) are recognized, including David McGee and Larry Hutchison, for locating Laclede records for NIST investigators during a visit to the Laclede steel mill.

Professors John Fisher and Al Pense (Lehigh University), and Drs. Keith Taylor and Bruce Bramfitt (International Steel Group), are thanked for discussions of WTC era steels and properties. 


\section{EXECUTIVE SUMMARY}

\section{E.1 OVERVIEW}

The World Trade Center (WTC) towers eollapsed on September 1 1, 2001, as a result of damage inflieted by aireraft and the ensuing fires. The properties of the stecl played an important role in how the building performed, from the initial impaet to the final eollapse. Struetural steel reeovered from the site has been a valuable resouree in the investigation of the disaster, providing information ranging from details of struetural response to the aireraft impaet to data on steel properties for insertion into models of building performance.

This report is an overview of the meehanieal and metallurgieal analysis of struetural steel from the WTC, part of the National Institute of Standards and Teehnology (NIST) Investigation of the WTC disaster. The purpose was to analyze struetural steel available from WTC 1,2, and 7 to determine the metallurgieal and meehanieal properties and quality of the metal, weldments, and eonneetions, and provide these data to other parts of the NIST WTC Investigation for insertion into models of building performance. The analysis foeused on steel from the towers to provide data for modeling building performanee and eharaeterizing the steel quality. In addition, the steel used in the eonstruetion of WTC 7 is deseribed based solely on data from the literature, beeause no steel from the building was reeovered.

The three goals were to:

1. Determine meehanieal properties of WTC struetural steel,

2. Determine the quality of the steel and if it met its design requirements, and

3. Analyze and provide insight into failure meehanisms for guiding the development of models of building performanee and validating their output.

\section{E.1.1 Building Design and Steel Specifications}

Building plans and material speeifieations from the eonstruetion era provided a starting point for the study. Thousands of pages of design doeuments were reviewed. Most valuable were the struetural steel design drawings for the WTC towers provided by the Port Authority of New York and New Jersey. In addition, Laelede Steel Company, the fabrieator of the floor trusses, provided eonstruetion-era doeuments that showed, amongst other information, that steels with higher strength than speeified were used in the floor truss systems. Numerous other sourees, ineluding Yawata (now Nippon) Steel doeuments on perimeter eolumn steel, provided essential insights into the steel fabrieation and properties.

From the standpoint of building design, the towers were unique based on the number of different steels speeified for eonstruetion. Fourteen different strengths of steel were speeified in the design drawings, although only 12 were aetually used. Most modern buildings use no more than two or three different strengths of steel. 
Furthermore, more than a dozen suppliers and fabricators supplied steel for the buildings. As a result, even when the different steels met a single specification, their properties could be significantly different. These complications resulted in more than forty different steels being used in the tower structures, all of which are characterized to some extent in this study.

\section{E.2 INVENTORY OF RECOVERED STEEL}

A total of 236 recovered pieces of WTC steel were cataloged; the great majority belonging to the towers, WTC 1 and WTC 2. These samples represented a quarter to half a percent of the 200,000 tons of structural steel used in the construction of the two towers. The NIST inventory included pieces from the impact and fire regions, perimeter columns, core columns, floor trusses, and other pieces such as truss seats and wind dampers.

The original, as-built locations of 42 recovered perimeter panels and 12 recovered core columns were determined, based on markings and geometry of the columns. Samples were available of all 12 strength levels of perimeter panel steel, the two strength levels of the core column steel that represented 99 percent of the total number of columns, and both strength levels used in the floor trusses.

A number of structural pieces were recovered from locations in or near the impact- and fire-damaged regions of the towers, including four perimeter panels directly hit by the airplane and three core columns located within these areas. These pieces provided opportunity for failure and other forensic analyses.

The collection of stecl from the WTC towers was sufficient for determining the quality of the steel and, in combination with published literature, for determining mechanical properties as input to models of building performance.

\section{E.3 DAMAGE AND FAILURE MODES OF THE STRUCTURAL STEEL}

Extensive failure analysis of the recovered stcel was conducted to determine damage characteristics, failure modes, and fire-related degradation of the recovered structural components. In addition, precollapse photographic evidence of the impact damage and location and intensity of the fires was used to distinguish between pre- and post-collapse damage.

Two sets of observations were made:

1. Pre-collapse analysis concentrated on impact damage sustained by the perimeter panel sections. The analysis employed enhanced photographic and video images of the towers and was largely limited to the perimeter panels, because the core columns and most floor trusses are not visible in the images. The images were also used to determine the location of precollapse fires, damage to fire proofing, and possible fire-related damage to the panels. In addition, some details of pre-collapse, time-dependent deformation of the structure, including bowing of perimeter columns across wide areas of the perimeter walls, were characterized.

2. Post-collapse analysis concentrated on the damage characteristics of the recovered structural steel elements. The perimeter panels were again evaluated, as well as the core columns and the connectors or seat assemblies used to attach the floor trusses to the core columns and 
perimcter column pancls. Of particular importance were the samples located ncar the airplane impact regions and those where fires burned before the collapse of the buildings.

In addition to the NIST analysis, an outside contractor made an independent study of the recovered stecl elements. In general, the observations conccrning local failure mechanisms by the eontractor agrecd with those that NIST found.

The observations of fracture and failure behavior, described below, wcre uscd by the groups that modeled the building performance during impact and subsequent firc to guide the devclopment of their modcls and validate their results.

\section{E.3.1 Structural Impact Damage - Perimeter Panels}

Correlation between pre-collapsc photographs and the recovcred exterior panels from the impaet zonc indicated that two of the four recovered impact-damaged pancls were in a condition similar to that just prior to building collapse. Some damage can be attributcd to the events during and after collapsc, but the general shape and appearance of the recovered pieces match the damage photographs.

The fracture bchavior of the plates from the rccovered columns that wcre hit directly by the aircraft was of particular interest. Transverse fractures of these plates (e.g., fracture through the outer webs of two impacted panels that occurred pcrpendicular to the rolling dircction) cxhibit ductilc characteristics, including necking and thinning away from the fracture. These features indicate that the steel behaved in a ductile manner under very high strain rates.

Conversely, fractures that occurred parallel and directly adjacent to welded joints exhibited little or no ductile characteristics. Diminished properties of the heat-affected zone in the base plate, the geometry of the joint with respect to the direction of impact, stress concentrations duc to the gcometry, and the orientation of the crack propagation with respect to the rolling dircction of the plate contributed to the lack of ductility. There was no evidence to indicate that the joining method, materials, or welding procedures were inadequate. The welds appeared to perform as intended.

In general, perimeter columns severed by the aircraft wings fractured at the internal stiffener or diaphragm plate associated with the spandrel connection to column. Other perimeter columns hit by the plane tended to fracture along heat-affected zoncs adjacent to welds. Perimcter columns outside the impact zone did not exhibit this behavior.

The failure mode of spandrel connections on pcrimeter panels differed above and below the impact zone. At or above the impact zone, bolt hole tear-out was more common. Below the impact zone, it was more common for the spandrels to be ripped off from the panels. The change in mode may be due to shear failures as the weight of the building during collapse came down on these lower pancls. There was no evidence that fire exposure changed the failure mode for the spandrel connections

With the exception of the mechanical floors, the perimeter panel column splices failed by fracture of the bolts. At mechanical floors, where splices were welded in addition to being bolted, the majority of the splices in the several recovered columns did not fail. 


\section{E.3.2 Structural Impact Damage - Core Columns}

Failure was noted in a limited number of recovered core columns as a result of both splice connection failures and fracture of the columns themselves. One recovered core column (WTC 2, column line 801, floors 77-80) may have sustained damage as a direct result of the airplane impact; however, the welded splice to the column above survived intact.

\section{E.3.3 Structural Damage - Floor Trusses and Seats}

In both towers, most of the perimeter panel floor truss connectors (perimeter truss seats) below the impact floors were either missing or bent downward. Above this level, the failure modes were more randomly distributed. This behavior apparently resulted from the building collapse sequence.

Failure of the welds associated with the perimeter panel floor truss connectors (perimeter seats) typically occurred as a result of the weld geometry, where the fracture occurred at the smallest cross-sectional area. Typically, these were the standoff plates. However, there was no evidence to indicate that the type of joining method, materials, or welding procedures were inadequate.

Of the 31 core floor truss connectors (core seats) recovered, about 90 percent were still intact, although many were extensively damaged. Only two were completely torn from the channel. This distribution may have resulted from the process used to select recovered steel from at the salvage yards, however.

In the recovered floor trusses, a large majority of the electric resistance welds at the web-to-chord connections failed. Failure of the connection between the floor truss and the perimeter panel floor truss connectors was typically a result of tab plate weld and bolt failure.

\section{E.3.4 Damage to Fireproofing Due to Aircraft Impact}

Pre-collapse photographs indicated that, as expected, fire-proofing was removed from pieces struck by the incoming aircraft or debris exiting the far side of the buildings. In addition, the impact caused fireproofing and aluminum facade panels to spall off many perimeter columns which were not directly struck nor severed, but apparently suffered strong accelerations and forces transmitted through the structure. This indirect damage to the sprayed fire-resistive materials (SFRM) was observed on the north and east faces of WTC 2.

A coating on the SFRM prevented the loss of the SFRM in some locations on the perimeter columns. This coating appeared as a band of white features on the SFRM wherever two aluminum panels met on the exterior columns of the buildings, becoming visible when the panels were dislodged. This may be a coating applied to protect the SFRM from moisture infiltration at the aluminum panel joints, acting to preserve the SFRM even when the SFRM was knocked off both above and below those locations.

\section{E.3.5 Time-Dependent Deformation of Perimeter Walls Due to Fire and Load Redistribution}

Images of WTC 1 showed gross deformations of the south wall prior to final collapse. Images taken approximately 5 min prior to collapse showed inward bowing of the exterior columns, reaching an observable maximum of about 55 in. near column 316 on the 96th floor. The inward deflection extended 
over the entire south faec of the building at this time, and was visible between the 94th and 100th floors. Photographs taken approximately $35 \mathrm{~min}$ prior to collapsc did not show any inward bowing of the south face of WTC 1.

Approximatcly 18 min after the impaet of the aircraft, the east faee of WTC 2 exhibited inward bowing of up to $10 \mathrm{in}$. in the region of the 79th to 83 rd floors. This inward bowing inercased to $20 \mathrm{in}$. at $5 \mathrm{~min}$ before eollapse of the tower.

Sagging floor slabs at the 82nd and 83rd floors were visible in window openings on the east and north faces, respeetively, of WTC 2 and the positions of these slabs ehanged over time. This suggests a progression of failure of eertain parts of the flooring in this area of the towcr.

At the moment of collapse of WTC 2, the top portion of the building was found to have moved to the west as it tilted to the southeast. During this tilting, a eomplex kink developed at the southeast eorner of the top of the building, in the region of the 106th floor. In addition, the portion of the building above the aireraft impact site twisted slightly eloekwise (as viewed from above) as the collapse progressed.

\section{E.3.6 Fire Exposure and Temperatures Reached by the Steel}

The pre-collapse photographie analysis showed that 16 reeovered exterior panels were exposed to fire prior to eollapse of WTC 1. None of the nine reeovered panels from within the fire floors of WTC 2 were observed to have been direetly exposed to pre-eollapse fires.

NIST developed a method to eharaeterize maximum temperatures experieneed by steel members using observations of paint cracking due to thermal expansion. The method ean only probe the temperature reaehed and it eannot distinguish between pre- and post-collapse exposure. More than 170 areas were examined on the recovered perimeter column panels; however, these eolumns represented only 3 percent of the perimeter eolumns on the floors involved in fire and cannot be eonsidered representative of other eolumns on these floors. Only three loeations had evidenee that the steel reaehed temperatures above $250^{\circ} \mathrm{C}$. These areas were:

- WTC 1, east faee, floor 98, column 210, inner web,

- WTC 1, east faee, floor 92, eolumn 236, inner web,

- WTC 1, north face, floor 98, eolumn 143, floor truss eonnector

Other forensic evidence indicates that the last example probably oecurred in the debris pile after eollapse.

Annealing studies on recovered steels established the set of time and temperature eonditions neeessary to alter the steel mierostrueture. Based on the pre-collapse photographie evidenee, the mierostruetures of steels known to have been exposed to fire were charaeterized. These mierostruetures show no evidenee of exposure to temperatures above $600{ }^{\circ} \mathrm{C}$ for any significant time.

Similar results, i.e., limited exposure if any above $250^{\circ} \mathrm{C}$, were found for the two eore eolumns reeovered from the fire-affeeted floors of the towers, whieh had adequate paint for analysis. Note that the perimeter 
and core columns examined were very limited in number and cannot be considered representative of the majority of the columns exposed to fire in the towers.

Perimeter columns exposed to fire had a greater tendency for local buckling of the inner web than those known to have no exposure. A similar correlation did not exist for weld failure.

\section{E.4 MECHANICAL PROPERTIES}

Mechanical properties of the steel were determined using tests at room temperature (for modeling baseline performance), high temperature (for modeling structural response to fire), and at high strain rates (for modeling the airplane impact). In addition, the structural steel literature and producer documents were used to establish a statistical basis for the variability expected in steel properties and for modeling steel properties as a function of temperature and strain rate for insertion into building performance models. A total of 32 distinct steels (various strengths and suppliers) were modeled in this manner.

A comparison of mechanical properties with relevant specifications and properties required by the design documents is included. The stecl used in the construction of the WTC generally met the expectations of the designers and the specifications called for in the steel contracts. Approximately 87 percent of all tested steel exceeded the required minimum yield strengths specified in design documents, and approximately 13 percent of the damaged steel tested did not meet the required minimum yield strengths. The occurrence of test results below the specified minimum values is not unexpected because differences in test procedures from those in the qualifying mill tests could account for $2 \mathrm{ksi}$ to $3 \mathrm{ksi}$ lower values in the NIST tests, the loss of a yield point due to damage to the steel accounts for $2 \mathrm{ksi}$ to $4 \mathrm{ksi}$ lower values in the NIST tests in sevcral cases, and variability exists within a heat of steel relative to the ASTM specified test location.

The yield strengths of the perimeter column steels generally exceeded their specified minimums by 10 percent to 15 percent. The tensile properties of the perimeter columns are consistent with literature estimates for average properties of construction steel plate during the WTC construction era. The number of occurrences of plates with tensile properties at or slightly below the specified minimum is consistent with the historical variability of steel strength.

The yield strengths of steels in the core columns, with a few exceptions, exceeded the specified minimum. The yield strengths of some wide-flange shapes were lower than called for in the specifications but, as stated above, this probably arose from a combination of mechanical damage that removed the yield point, differences between the NIST and original mill test report testing protocols, and variability within a heat of steel relative to the ASTM International (ASTM) specified test location. Regardless of the source, the observed distributions are accounted for in the typical design factor of safety for allowable stress design. The yield strengths of undamaged steels in the rollcd core columns, however, were lower than the historical literature indicates as typical.

The strength of the steel in the floor trusses was higher than called for in the original specifications. Many of the truss steels that were specified as low strength A 36 were supplied as high-strength, low-alloy steels with much higher strengths. Laclede Steel Company's substitution of 50 ksi yield strength steel for A 36 in the lower chord of the trusses is expected to have provided significantly improved performance at high temperature. 
The limited tests on bolts indicated that their strengths wcre greater than the specificd minimums, and they were stronger than contcmporancous litcraturc suggcsts as typical.

Limited tests on recovercd welds and weld matcrial indicatcd that their mechanical propertics and chcmistry were consistent with thcir intended specifications.

The strain rate sensitivity and high-strain rate ductility of the perimeter and corc column stcels werc similar to other construction stcels of the WTC cra. The impact toughness of stecls from the perimeter and core columns, and floor trusses was consistcnt with literature valucs for the WTC construction cra.

The high-temperature yield and tensile strength bchavior of WTC steels was similar to bchavior of construction stcels from the WTC construction-cra literaturc. The crecp bchavior of WTC steels was found to be best modeled by scaling WTC-era literature data using room tempcrature tensilc strength ratios.

In summary, the steel used in the construction of the WTC towers met the expectations of the designers and the specifications called for in the steel contracts. Material substitutions of higher strength steels were common in the perimeter columns and floor trusses. The safety of the WTC towers on September 11, 2001, was most likely not affected by the fraction of steel that, according to NIST testing, did not meet the required minimum yield strength. The typical factors of safety in allowable strcss design can accommodate the measured property variations below the minimum.

\section{E.5 PHYSICAL PROPERTIES}

A number of physical properties of the structural steel from the towers were either measurcd or estimated. Of these, composition and microstructure were characterized for many of the recovered pieces in order to identify the specifications to which the steel was fabricated, enabling a better characterization of the mechanical properties of the steel. In addition, thermal properties were estimated as a function of temperature in order to provide input to models of the steel thermal response to the fires.

Chemical analyses of the flange, outer web, and spandrel plates of the exterior panel sections wcre found to be nearly identical for a given plate gauge and yield strength, as were inner web plates with yield strengths equal to $80 \mathrm{ksi}$ or $100 \mathrm{ksi}$. In contrast, inner web plates with yield strengths less than $80 \mathrm{ksi}$ were found to be chemically distinguishable from the other plates. These results support the contemporancous documents stating that Yawata Steel (now Nippon Steel) produced all flange, outer web, and spandrel plates, and that inner web plates were primarily supplied domestically. The alloying practices were typical for steels of this era.

Chemistry results for the core columns varied for any given strength and shape (built-up box, rolled wideflange). This result supports the contemporaneous documents that state numerous suppliers produccd the steel to be used for these structural components. All core columns tested met chemistry specifications for one of the numerous ASTM structural steel grades available during the construction era.

Floor truss rods and chords, manufactured by Laclede Steel Co., met chemistry specifications for ASTM A 242. Contemporaneous construction documents indicated that Laclede Steel Co. routinely upgraded A 36 components to A 242 steel. 
Two types of bolts were specified for construction of the towers, A 325 and A 490 bolts. Stampings on the bolt heads clearly indicated the bolt type. Chemical analysis indicates the A 325 bolts met the A 325 Type 1 chemistry specifications.

A majority of the other structural components (floor truss seats, diagonal bracing straps, gusset plates, core channels, etc.) met chemistry specifications for ASTM A 36 grade steel, which was the default steel when strengths were not specified on the design drawings.

\section{E.6 STRUCTURAL STEEL IN WTC 7}

No steel was recovered from WTC 7; however, construction-related documents describe the structural steel as conventional $36 \mathrm{ksi}, 42 \mathrm{ksi}$, and $50 \mathrm{ksi}$ steels. The building plans called for rolled column shapes conforming to two ASTM grades: A 36 and A 572 Grade 50. Cover plates for the heaviest plates were specified as A 588 Grades 42 and 50, and A 572 Grade 42. There is a substantial literature base on the properties of these steels.

The literature of the construction period was researched in order to estimate properties and provide models of room temperature mechanical properties of the various steels. Methods developed for the WTC tower steels were used to model the high temperature mechanical performance for the building performance models of WTC 7 response to the fires.

\section{E.7 ISSUES}

Based on the Investigation findings, NIST identified a detailed set of issues related to practice, standards, and codes that provided the basis for formulating the Investigation's draft recommendations. The Investigation team has studied practices ranging from those used during construction of the towers to newly available practices that could improve the safety and performance of high-rise buildings. The recent development and use of "fire-resistant" steel in Europe and Japan falls in the latter category.

Fire-resistant steels are reported to retain a higher fraction of their room temperature strength at temperatures expected in building fires, and are used either with or without fire protection depending on the application. If fire-resistant steels do indeed retain improved high temperature properties, then improved fire resistance would be expected even in cases where conventional fire protection has been damaged, whether during normal construction and modifications, or due to other damage as in the attack on the WTC towers.

Each issue identified by NIST was divided into three levels with between two and five categories each:

- Categories in Level 1: practices; standards, codes, and regulations; adoption and enforcement; research and development or requiring further study; and education and training.

- Categories in Level 2: all tall buildings (buildings over 10 stories in height); selected tall buildings (buildings over 10 stories in height that are at risk due to design, location, use, iconic status, contents, etc.); selectcd other buildings (buildings that are at risk due to design, location, use, historic/iconic status, contents, etc.). 
- Categories in Level 3: related to the outeome on September 11, 2001 (i.c., could have changed the outeome); or unrelated to the outcome on September 11, 2001 (i.c., would not have changed the outcome yet is an important building and fire safety issue that was identified during the course of the Investigation).

Under Level 1, the fire-resistant steel issue is considered to include practices and research and development or requiring further study. The fire-resistant steel issue under Level 2 applies to all tall buildings and selected other buildings. Under Level 3, the use of fire-resistant steel in the WTC towers may have increased the time to collapse or even prevented the collapse of the towers.

Discussion of this issue is not intended to suggest that fire-resistant steels should have been used in the construetion of the WTC towers, or even that fire-resistant stecls were available commercially at the time of their construction. 
This page intentionally left blank. 


\section{Chapter 1 \\ INTRODUCTION}

\section{$1.1 \quad$ OVERVIEW AND SCOPE}

The collapses of the World Trade Center (WTC) towers on September 11, 2001, werc a result of damage inflicted by the aircraft impact and the ensuing fires within the two buildings. The performance of the steel within the structures played a key role in how the buildings performed, from impact to final collapsc. Structural steel recovered from the site has been a valuable resource in the investigation of the disaster, providing information ranging from details of structural response to impact, to data on stcel properties for insertion into models of building performance.

This report provides an overview of the mechanical and metallurgical analysis of structural steel from the WTC, part of the National Institute of Standards and Technology (NIST) Investigation of the WTC disaster. The purpose was to analyze structural steel available from WTC 1, 2, and 7 to determine the metallurgical and mechanical properties and quality of the metal, weldments, and connections.

The analysis focused on steel from the towers to provide:

1. Mechanical properties of WTC structural steel for insertion into building performance models,

2. An assessment of the quality of the steel and design requirement compliance, and

3. Analysis and insight into failure mechanisms for guiding and validating models of building performance.

A total of 236 pieces was recovered and cataloged, and the original, as-built location for many of the pieces has been identified. These pieces include perimeter columns, core columns, trusses, and other pieces such as truss seats and wind dampers, including many pieces from the fire and impact regions. NIST has examples of the many grades of perimeter columns and spandrels, the two grades of wideflange and built-up box core columns (representing 99 percent of the core columns), the two grades of steel in the floor trusses, and samples of core and perimeter truss seats. The collection of steel from the WTC towers was sufficient for determining the quality of the steel and, in combination with published literature, for determining mechanical properties as input to models of building performance.

WTC 7 was constructed in 1986, using conventional $36 \mathrm{ksi}, 42 \mathrm{ksi}$, and $50 \mathrm{ksi}$ steel produced to ASTM International (ASTM) specifications. Since no steel from WTC 7 was recovered from the site, the steel used in the construction of this building is described based on data from the literature of the period.

From the standpoint of building design, the towers were unique based on the number of different steels specified for construction. Fourteen different strengths of steel were specified in the design drawings. compared with two or three different steels in most modern buildings. Furthermore, there were numerous suppliers and fabricators of the steel used in the buildings, sometimes with significantly different steel 
properties even when supplying to the same specification. These complications resulted in at least 32 different steels being used in the tower structures, all of which are characterized based on the approach described in the following section.

\section{$1.2 \quad$ APPROACH}

This Investigation analysis was divided into six tasks as follows:

- Task 1-Collect and catalog the pliysical evidence (structural steel components and connections) and other available data, such as specifications for the steel, the location of the steel pieces within the buildings, and the specified steel properties.

This task consisted of two major areas. The first was the collection and analysis of the enormous amount of contemporaneous (1960s era) documentation, ranging from design, specification and construction documents to data from the numerous structural steel fabricators. Results of the analysis are summarized in

Chapter 2 - Tower Design - Structural Steel Documents

Chapter 3 - Contemporaneous Steel Specifications

Chapter 4 - Contemporaneous Construction Specifications

The second major area under this task involved cataloging the structural steel recovered from the WTC site. The 236 recovered pieces included many examples of the structural elements of major importance, such as core columns, perimeter panels, floor trusses, and truss seats. These pieces, and in many cases the precise as-built location within the buildings, are described in

Chapter 5 - Steel Inventory and Identification

- Task 2-Document failure mechanisms and damage based on visual observations of recovered steel, especially for available columns, connectors, and floor trusses.

Extensive failure analysis of the recovered steel was conducted. In addition, pre-collapse photographic evidence of the impact damage and location and intensity of the fires was used to characterize damage to the buildings due to aircraft impact and details of damage to structural elements and fire-proofing. These images were also used to distinguish between pre- and postcollapse damage. The response of the building to the firc and redistribution of loads resulted in bowing of perimeter columns, which was characterized as a function of time. Details of fracture and failure behavior were supplied to the NIST staff who were modeling building performance during impact and subsequent fire to provide guidance and validation of model results. These failure studies are summarized in

Chapter 6 - Damage and Failure Analysis of Structural Steel

- Task 3-Determine the metallurgical and nechanical properties of the steel, weldments, and connections, including temperature dependence of properties. Identify the grades of steel in the columns, welds, spandrels, trusses, truss seats, and fasteners, based on composition, nicrostructure, and mechanical and impact properties. Provide steel property data, including models of elevated temperature behavior for relevant steels, to those Investigation efforts 
modeling damage to the structural steel members from aircraft impact, stmutural fire response, and initiation and propagation of structural collapse.

The mechanical test program included testing of representative samples of the numerous types of steel in the WTC towers. A variety of test methods were used to characterize room temperature properties. tensile properties at high-strain rates, and performance at high temperatures typical of building fires. In addition, the structural steel literature and producer documents were used to establish a basis for the statistical variability expected in steel properties and for modeling steel properties as a function of temperature and strain rate for insertion into building performance models. A total of 32 steels were modeled in this manner. A comparison of mechanical properties with relevant specifications and properties required by the design documents is included. These are reported in

Chapter 7 - Mechanical Properties of Structural Steels

Composition and microstructure were characterized in order to fully identify the various steels. Other physical properties, needed for the finite element models of the buildings. were determined from the literature, including specific heat. coefficient of thermal expansion, and thermal conductivity. all as a function of temperature. These analyses, including relationships suitable for insertion into the building models, are reported in

Chapter 8 - Physical Properties of Structural Steels

Analogous information on mechanical properties of the structural steels of WTC 7 , as derived from the literature, is also summarized in Chapter 8.

- Task 4-Correlate determined steel properties with the specified properties for construction of the buildings. The quality of the steel used in the buildings will be compared with that specified. This determination depended upon mechanical properties and, thus, is included in Chapter 7.

- Task 5-Analyze the steel metallographically to estimate maximum temperatures reached, recognizing that high-temperature exposure before the collapse may be difficult to distinguish from exposure during post-collapse fires.

This analysis was closely tied to failure analysis and, thus, is reported in Chapter 6.

- Task 6-Report preparation.

The present report summarizes the results of the investigation of the recovered steel. In addition. the following technical reports provide supporting technical details:

Contemporaneous Structural Steel Specifications (NIST NCSTAR 1-3 I $^{1}$ )

Steel Inventory and Identification (NIST NCSTAR 1-3B)

Damage and Failure Modes of Structural Steel Components (NIST NCSTAR 1-3C)

Mechanical Properties of Structural Steels (NIST NCSTAR 1-3D)

Physical Properties of Structural Steels (NIST NCSTAR 1-3E)

1 This reference is to one of the companion documents from this Investigation. A list of these documents appears in the Preface to this report. 
This page intentionally left blank. 


\section{Chapter 2 \\ TOWER DESIGN - STRUCTURAL STEEL DOCUMENTS}

\section{$2.1 \quad$ INTRODUCTION}

This chapter describes the World Trade Center (WTC) tower structure and critical structural clements relevant to the analysis of the structural stcel from the towers. The description includes the structural design and propertics specified by the structural enginecrs for columns, floor systems, and connections. A morc detailed description can be found in National Institute of Standards and Tcchnology (NIST) NCSTAR 1-3A.

Information needed for the metallurgical charactcrization was obtained from the structural stecl drawings provided by the Port Authority of New York and New Jerscy and the structural database asscmbled by Leslie E. Robertson Associates for the NIST Investigation (NIST NCSTAR 1-2A). The complexities introduced by the size of the structure and the specification of fourteen different strengths of stecl led the designers to a tracking system whereby the steel fabricators stamped and/or stencilcd each structural element with a unique identifying number (see Chapter 5). The structural enginecring drawings included these identifying numbers as well as the yield strength of the individual steel components. Thus, when NIST was able to find the identifying number on an element such as a perimctcr column panel, then the particular steel specified for each component of the clement was known.

\subsection{SPECIFICATION OF STEEL GRADES (MINIMUM YIELD STRENGTH)}

Specifications for structural steel (ASTM International [ASTM], American Iron and Stecl Institutc, etc.) typically place limits on chemical composition or mechanical properties or, most commonly, both. Various mechanical properties may be specified, such as tensile strength, minimum yield strength, ductility, and toughness. Other material properties may not appear in a specification, yet arc critical in building design; the most important such property is pcrhaps the elastic modulus, or stiffness, which does not appear in spccifications because there is little variability amongst various stecls.

In practice, the material property of greatest importance for characterizing a particular steel is the yield strength $\left(F_{y}\right)$. In the United States, steel is often referred to according to its yield strength; for example, a "50 ksi steel" is steel with a minimum yield strcngth of 50,000 pounds per square inch. Skilling, Helle, Christiansen, \& Robertson (SHCR), structural engineers for the WTC towers, followed this convention, and the design drawings were marked with the minimum yield strength for each piece of structural steel.

\subsection{STRUCTURAL OVERVIEW}

The WTC tower buildings had a frame-tube construction consisting of closely spaced perimeter columns coupled to a rectangular service core (Fig. 2-1). The buildings had a square footprint, $207 \mathrm{ft} 2 \mathrm{in}$. $(63.14 \mathrm{~m})$ on a side with chamfered corners. From the 9 th to 107 th floors, the perimeter columns consisted of closely spaced built-up box columns. The service core at each building's center was approximately $87 \mathrm{ft}$ by $137 \mathrm{ft}(26.5 \mathrm{~m}$ by $41.8 \mathrm{~m})$ and connected to the pcrimeter columns by a floor panel 
system that provided an essentially column-free office space, see Fig. 2-1. In addition to showing the location of perimeter and core columns, Fig. 2-2 describes the column numbering scheme used to identify each column on a given floor.
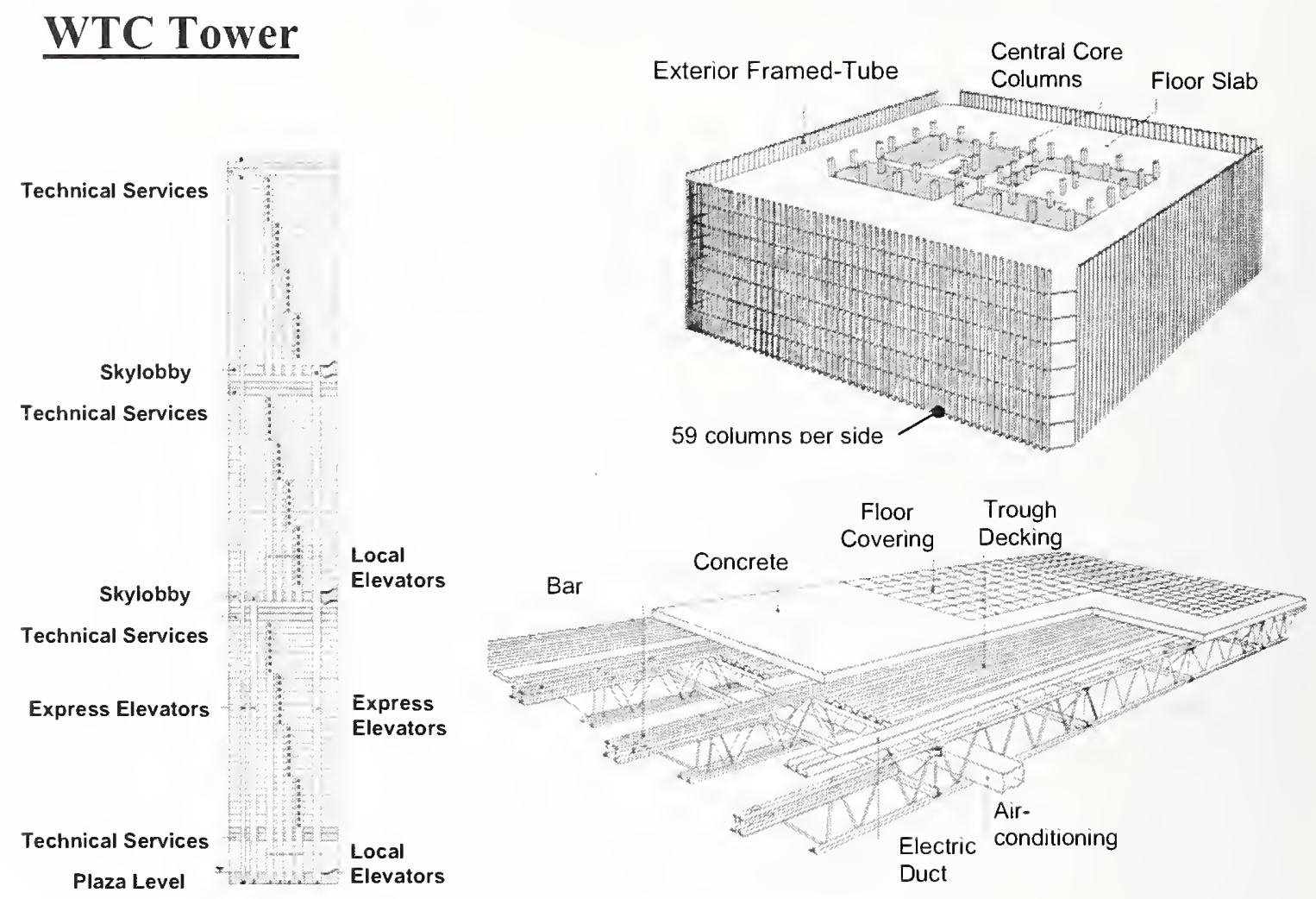

Figure 2-1. Schematic diagram of the tower structure.

The WTC tower structural steel plans (SHCR 1967) point out the major structural elements of interest. These features include the perimeter columns, the core columns and associated framing, the trusses that supported the floors, and the connections between and within these elements. In addition, a "hat truss" located within the 107th to 110 th floors tied the core to the perimeter columns and provided a base for the television mast atop WTC 1 and support for a proposed mast atop WTC 2.

The structural steel drawings provide the location, cross-sections, and grade of steel (i.e., required minimum yield strength) for each of the thousands of structural elements in the buildings. In all, 14 different grades of steel were specified, ranging in yield strength from $36 \mathrm{ksi}$ to $100 \mathrm{ksi}$. In addition to yield strength requirements, Port of New York Authority (PONYA) documents specified allowable steels, bolts and welds using ASTM or other standards. 


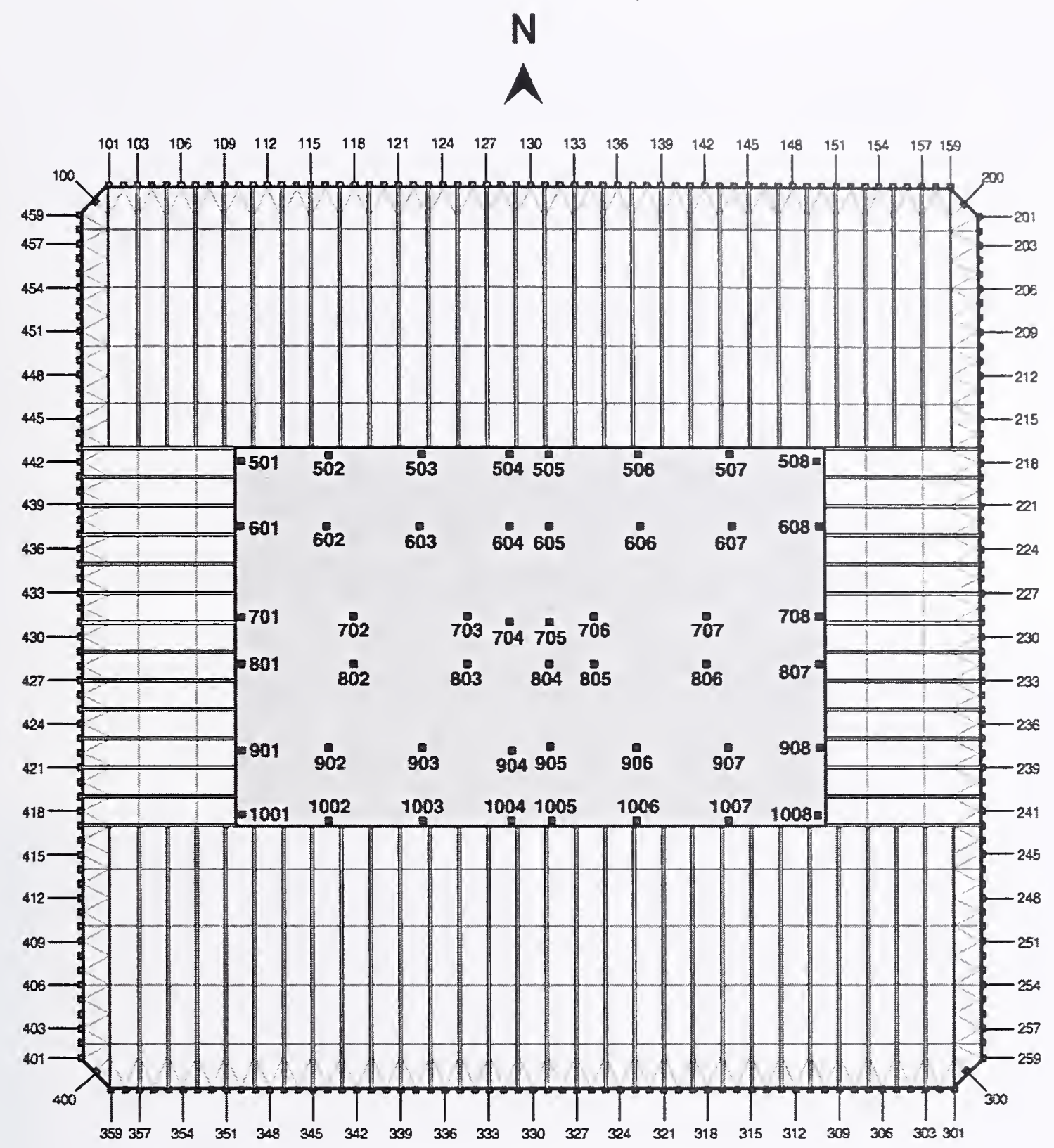

Figure 2-2. WTC 1 tower floor plan and column numbers.

\subsubsection{Perimeter Columns}

Between the 9th and 107th floors, the perimeter structure consisted of closely spaced, built-up box columns. Each building face consisted of 59 columns spaced at $40 \mathrm{in} .(1.02 \mathrm{~m})$. The columns were fabricated by welding plates of steel to form an approximately 14 in. $(0.36 \mathrm{~m})$ square section (Fig. 2-3). Adjacent columns were interconnected at each floor level by deep spandrel plates, typically $52 \mathrm{in}$. $(1.32 \mathrm{~m})$ deep (Fig. 2-4). The spandrels formed an integral part of the columns: there was no inner web plate at spandrel locations. Spandrels were generally specified with a yield strength lower than that of the column webs and flanges, as well as a heavier gauge than the adjacent inner webs. Spandrel thicknesses ranged from $0.375 \mathrm{in.}$ to $1.375 \mathrm{in}$. 


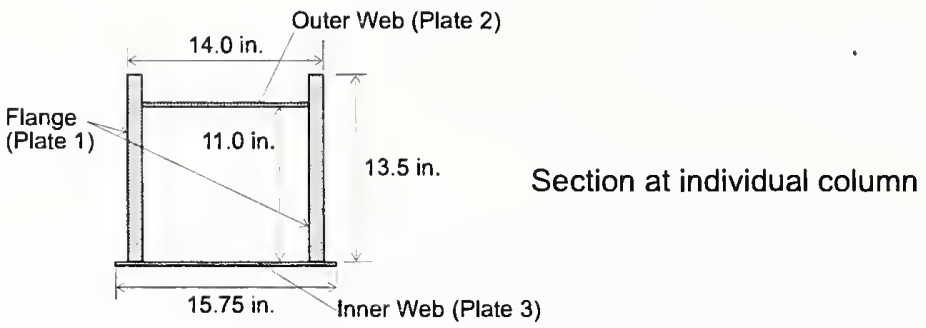

Outside of building

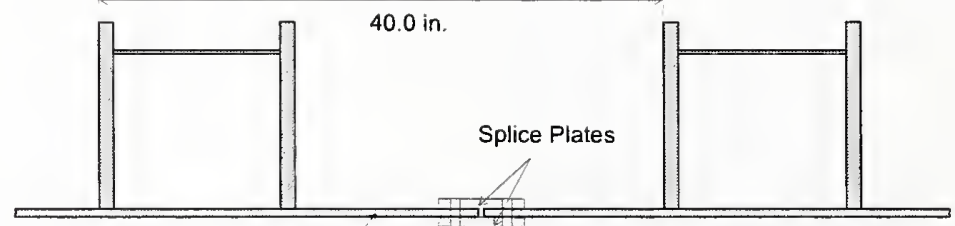

Spandrel Plate (Plate 4)

Inside of building

Section at spandrel

Figure 2-3. Cross-section of perimeter columns; sections with and without spandrels.
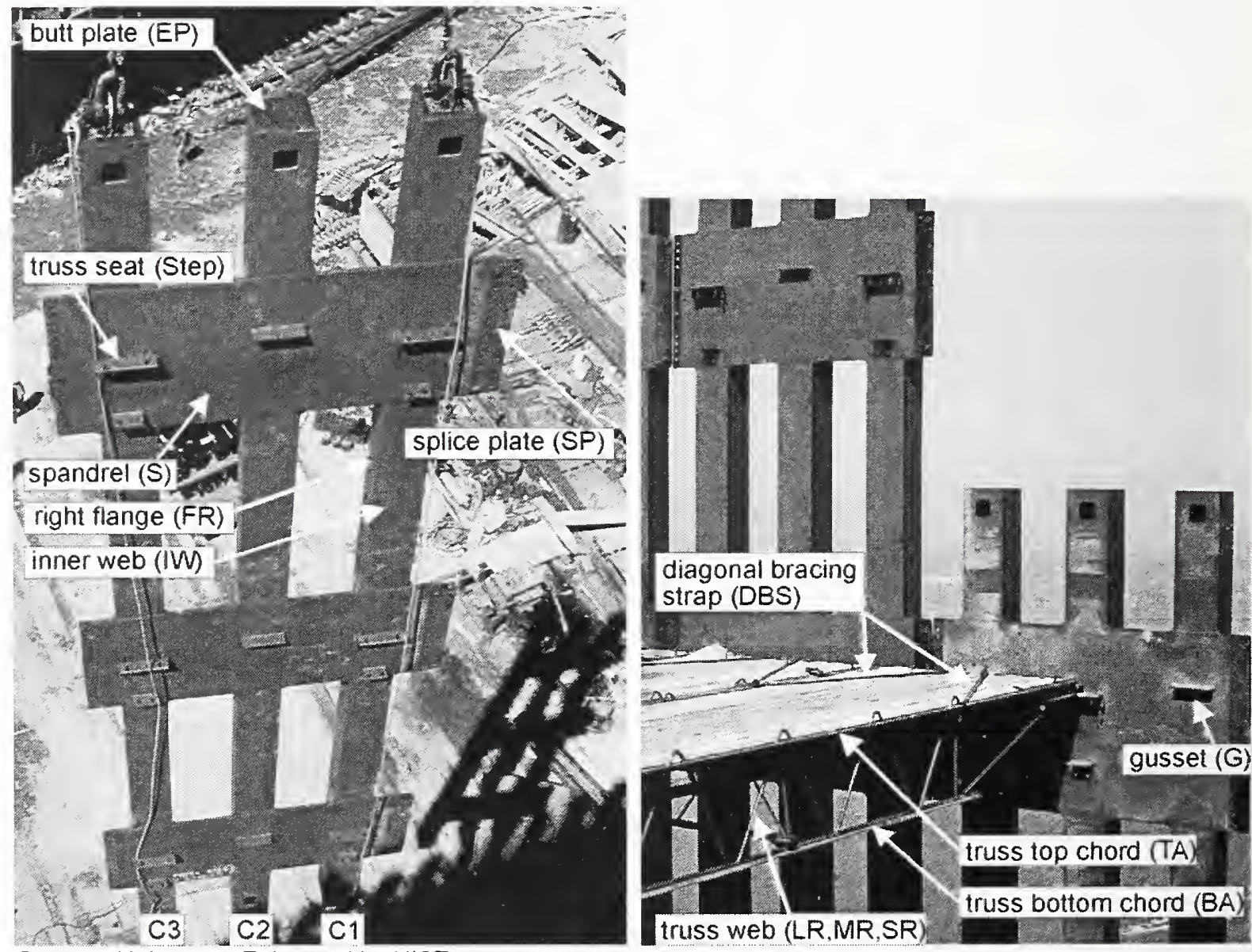

Source: Unknown. Enhanced by NIST.

Figure 2-4. Characteristic perimeter column panel consisting of three full columns connected by three spandrels. 
The perimeter columns were prefabricatcd into pancls, typically threc storics tall and threc columns widc (Fig. 2-4). Other than at the mechanical floors, pancls werc staggercd (Fig. 2-5) so that only onc-third of the units wcre spliced (i.c., connected) in any onc story. Hcavy cnd, or "butt" plates with $F_{y}=50 \mathrm{ksi}$ and $1.375 \mathrm{in}$. to $3 \mathrm{in}$. ( $3.5 \mathrm{~mm}$ to $7.6 \mathrm{~mm}$ ) thick wcrc weldcd to the top and bottom of cach column. Fillet welds were used inside the columns along threc edgcs, with a groove wcld on the fourth, outsidc cdgc. During erection, abutting spandrels were bolted together, and columns werc boltcd to the adjaccnt columns, all using ASTM A 325 bolts cxccpt for the heaviest butt plates, which uscd ASTM A 490 bolts.

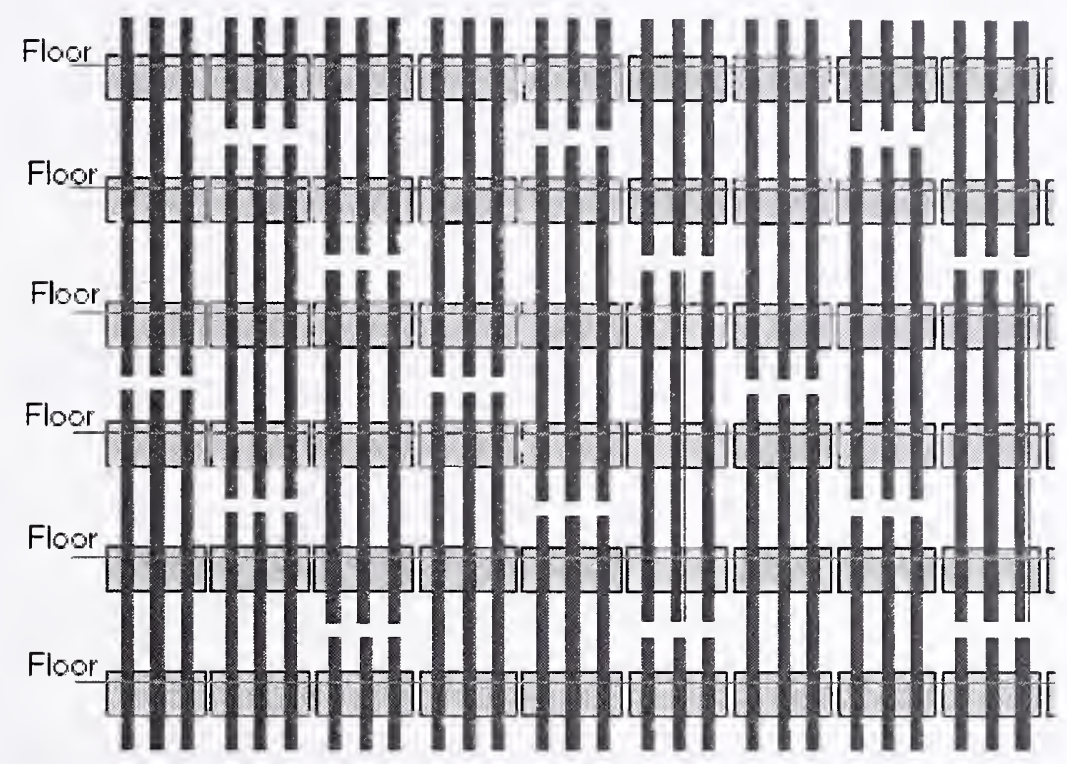

Figure 2-5. Partial elevation of exterior bearing-wall frame showing exterior wall module construction. Highlighted panel is three stories tall (36 ft) and spans four floors. Distance between panels has been exaggerated.

Fourteen grades of steel were specified in the design documents for the perimeter columns, with minimum yield strengths of $(36,42,45,46,50,55,60,65,70,75,80,85,90$, and 100) ksi. Twelve grades of steel were specified for the spandrels, with the same strength levels as the columns but without the two highest strength steels. The structural steel drawings indicate that the flanges and webs of a given column section consisted of a single grade (i.e., minimum yield strength) of steel, but each column and spandrel within a single pre-fabricated panel could be fabricated from different grades of steel.

Perimeter columns in the upper stories were typically fabricated of lighter gauge steel, most commonly $0.25 \mathrm{in} .(6.35 \mathrm{~mm})$, with the grade of steel presumably dictated by the stresscs induced by the calculated gravity and wind loads. In this manner, the weight on the lower stories would be minimized (reducing elastic distortion during construction), a design goal important in very tall buildings. A further consideration may have been to reduce the weight and thus the difficulty in raising heavy structural pieces as high as $1,300 \mathrm{ft}$ above ground level. In contrast to the upper stories, in the lower stories, the perimeter column flanges were as thick as $3 \mathrm{in}$. (76 mm) and typically made of the lower strength steels. The larger cross sections and lower applied stresses associated with the lower strength steels also served to decrease the elastic deflections in the building. 


\subsubsection{Core Columns}

Core columns were of two types: welded box columns and rolled wide flange shapes. The columns in the lower floors were primarily huge box columns as large as $12 \mathrm{in}$. by $52 \mathrm{in}$. ( $0.30 \mathrm{~m}$ by $1.32 \mathrm{~m})$ composed of welded plates up to $7 \mathrm{in}$. (178 mm) thick. In the upper floors, the box columns transitioned to the rolled wide flange shapes. Fig. 2-6 indicates the transition floors for each of the core columns, and Fig. 2-7 shows typical geometries of box columns and wide flange columns at the 84th floor. Core columns were typically spliced at three-story intervals. The splices in the impact and fire zones of both buildings were at floors $75,77,80,83,86,89,92,95,98$, and 101. Diagonal bracing was used at the mechanical floors and in the area of the hat truss. Core box columns were $36 \mathrm{ksi}$ or $42 \mathrm{ksi}$. Core wide flange columns were specified to be one of four grades, but were primarily $36 \mathrm{ksi}$ and $42 \mathrm{ksi}$ steel; only about 1 percent of all the core columns were made of $45 \mathrm{ksi}$ or $50 \mathrm{ksi}$ steel.

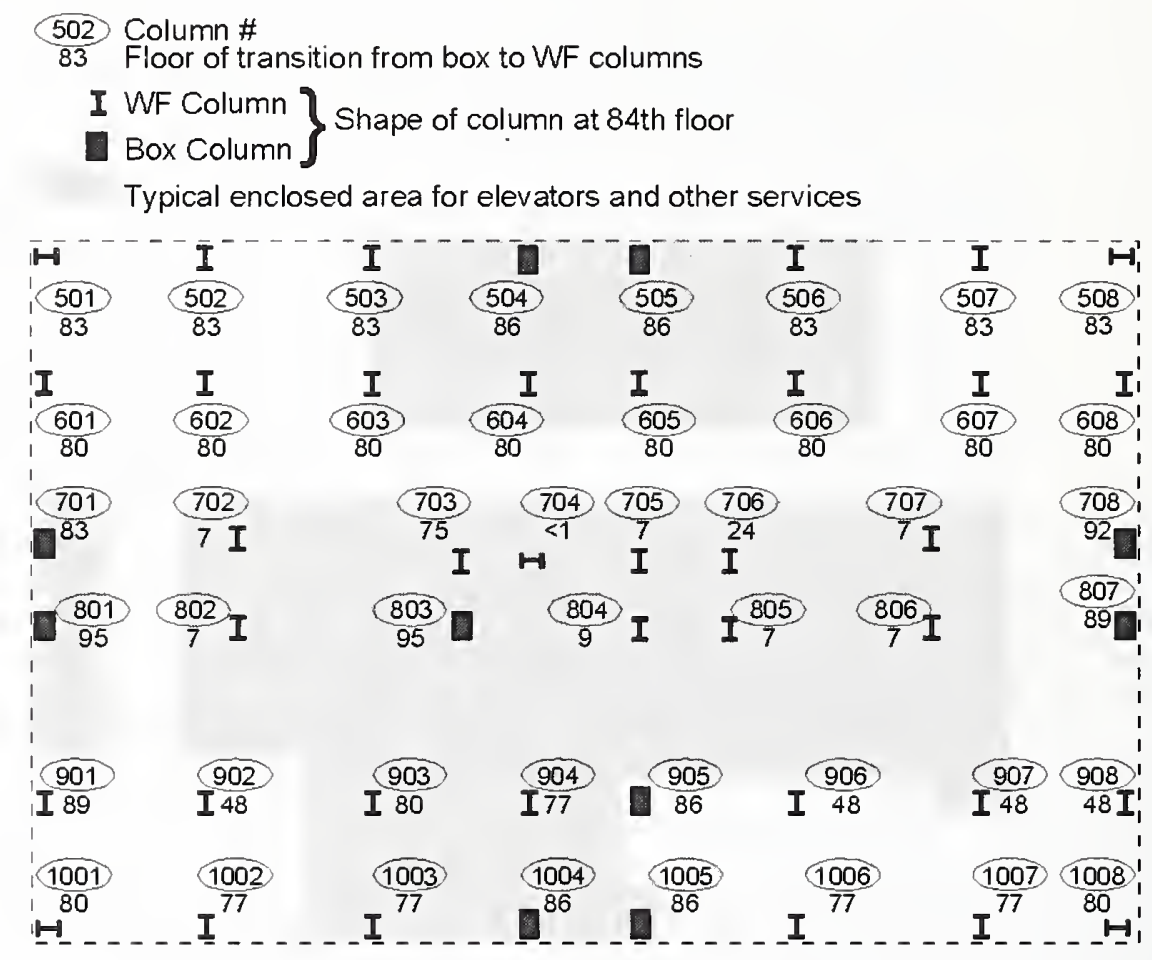

Figure 2-6. Core column layout in WTC towers.

The core area was framed conventionally with beams. There were numerous openings in the core area floor for elevators and stairwells. Since fewer elevators served the upper floors, part of the core area was not needed for services. In Fig. 2-6 the dashed line shows the perimeter of the core, and shaded areas indicate typical enclosed areas for elevators and other services.

\subsubsection{Flooring System}

In the great majority of floors, the floor area outside the central core was supported by a series of 29 in. $(0.74 \mathrm{~m})$ deep floor trusses that spanned between the core and perimeter wall, Fig. $2-8$. At the core, the floor trusses were bolted to seats welded to channels that ran continuously along the edge of the core. At the perimeter columns, the floor trusses were bolted and then welded to seats, mounted on spandrels at every other column. The floor trusses were approximately $60 \mathrm{ft}(18.3 \mathrm{~m})$ or $35 \mathrm{ft}(10.7 \mathrm{~m})$ long 
(depending upon the relative orientation of the building core), spaced at $6 \mathrm{ft} 8 \mathrm{in}$. $(2.0 \mathrm{~m})$. Therc werc dozens of variants, with differcnces in length, top and bottom chord size, bcaring angles at the truss cnds, gauge of web diagonals, and prescnce or absence of chord platcs.
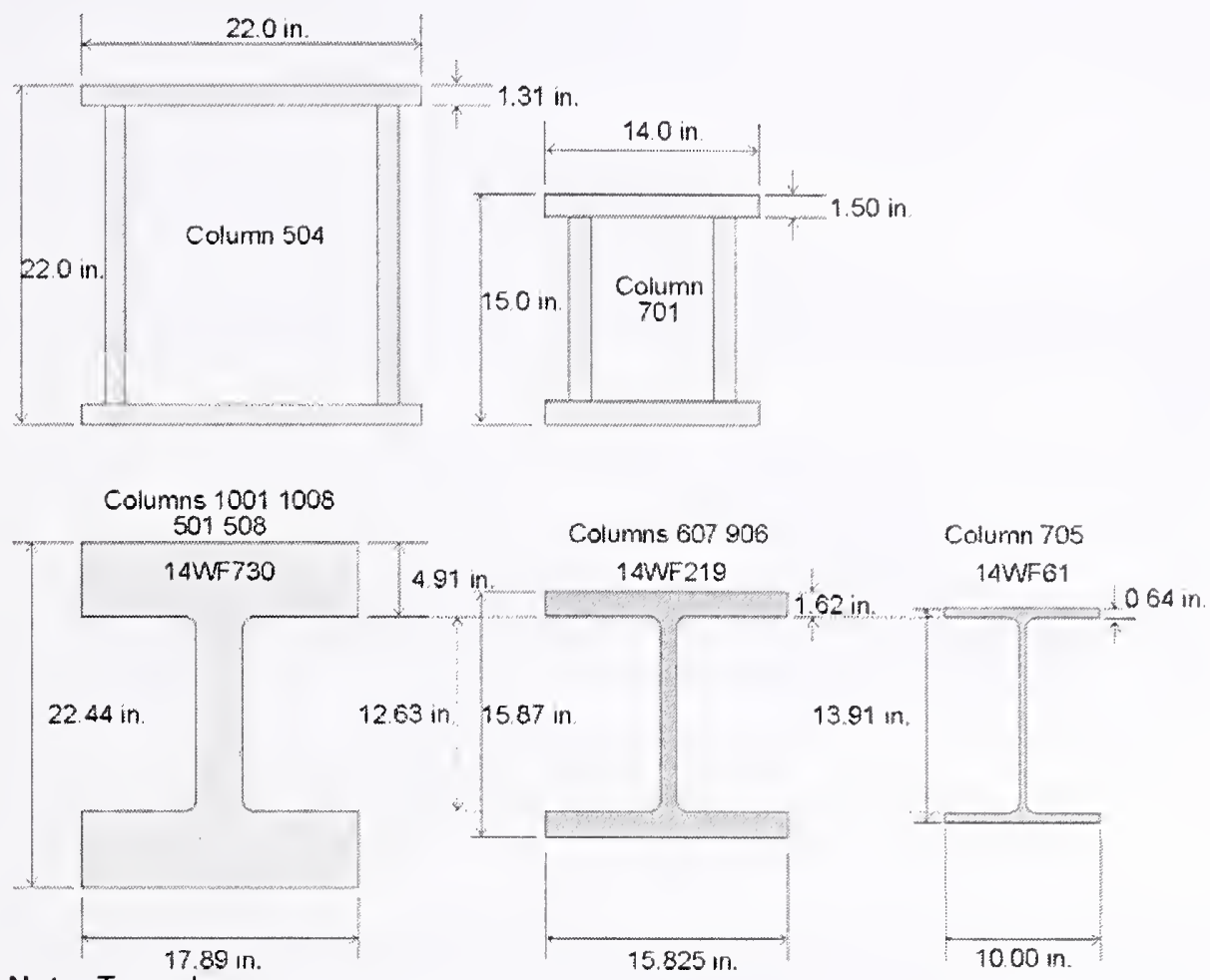

Note: To scale.

Figure 2-7. Typical welded box members and rolled wide flange shapes used for core columns between floors 83 and 86 .

The prefabricated floor modules were typically $20 \mathrm{ft}(6.1 \mathrm{~m})$ wide, containing two sets of doubled trusses in the interior and a single truss along each edge. Thus, each seat supported either a double truss within a floor panel, or two single trusses from adjacent floor panels. In addition, the bottom chord of each pair of trusses was attached to perimeter spandrels with visco-elastic dampers. Bridging trusses ran perpendicular to the main bar trusses and were spaced at $13 \mathrm{ft} 4 \mathrm{in} .(4.06 \mathrm{~m})$. The floor panels were covered with a corrugated steel floor deck that rested on the bridging trusses and deck support angles running intermediately between bridging trusses. Flutes in the deck ran parallel to the main trusses. Once in place, 4 in. ( $100 \mathrm{~mm}$ ) of lightweight concrete was poured for the floor. Figure 2-8 shows an assembled floor panel before the concrete floor was poured.

The minimum yield strength of the steel for the floor trusses was specified to be $50 \mathrm{ksi}$ "unless otherwise noted." In practice, several of the designs specified $36 \mathrm{ksi}$ steel as well as $50 \mathrm{ksi}$ steel (see Chapter 3 for details).

All seats were specified to be of $36 \mathrm{ksi}$ minimum yield strength. There were more than 30 varieties of perimeter seats, with various thicknesses from $3 / 8 \mathrm{in}$. to $7 / 8 \mathrm{in}$. in $1 / 8 \mathrm{in}$. increments $(9.5 \mathrm{~mm}$ to $22.2 \mathrm{~mm}$ in $3.2 \mathrm{~mm}$ increments). Core seats were $7 / 16 \mathrm{in}$., $1 / 2$ in., $5 / 8$ in., or $3 / 4 \mathrm{in}$. (11.1 mm, $12.7 \mathrm{~mm}, 15.9 \mathrm{~mm}$, or $19 \mathrm{~mm}$ ) thick. 


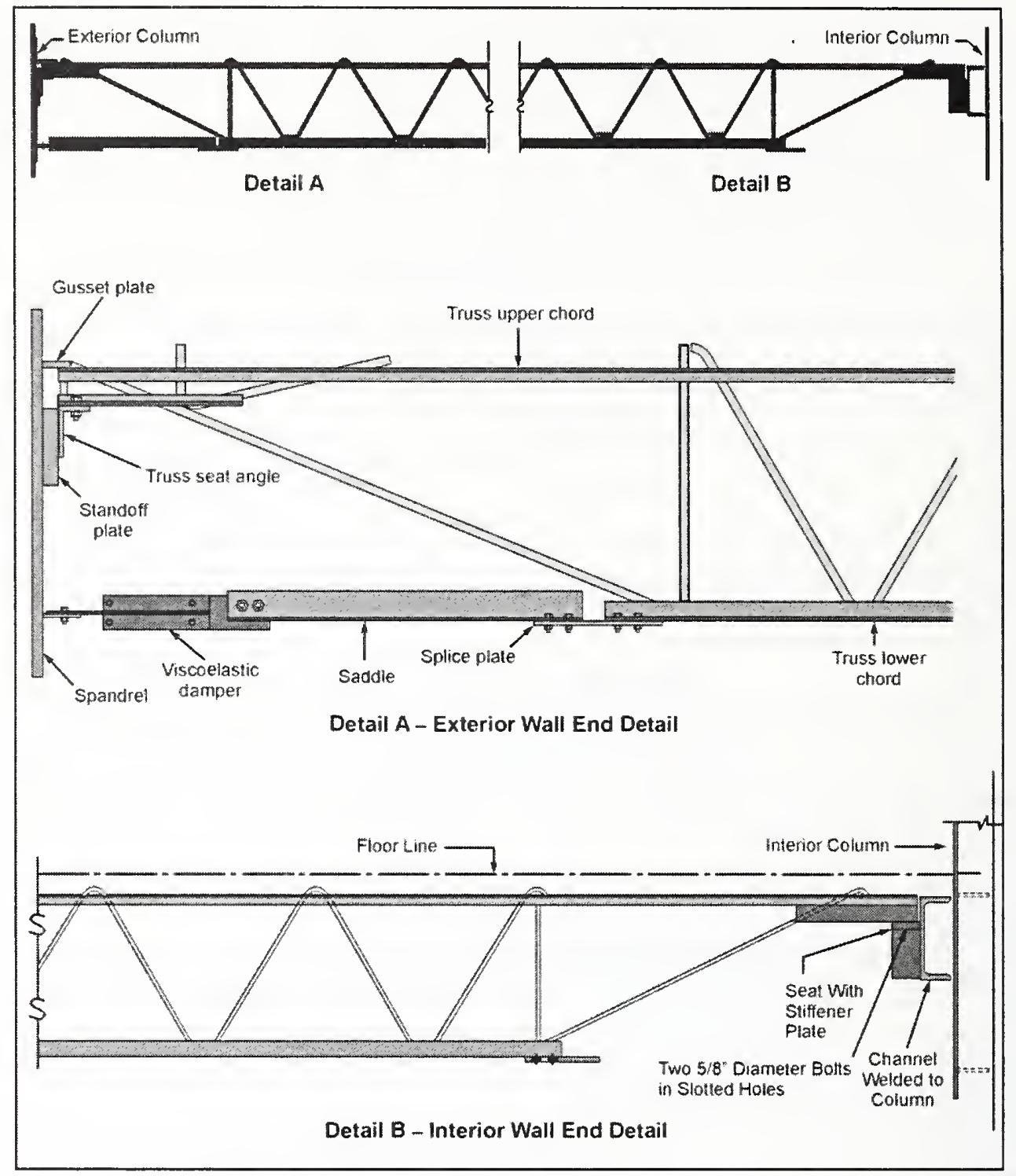

Figure 2-8. Schematic diagram of a floor truss.

Certain floors outside the core were supported by rolled structural steel shapes rather than trusses. These included the mechanical floors (e.g., floors 75 and 76) and the floors just above the mechanical floors (e.g., floor 77). Beam framing was typically W2 $7^{2}$ beams in the long span region and W16 beams in the short direction with beams spaced at $40 \mathrm{in}$. The floor was $5.75 \mathrm{in}$. thick, normal-weight concrete poured on a 1.5 in. fluted steel deck, acting compositely with the steel beams. The concrete on the beam-framed fleors above the mechanical floors was $8 \mathrm{in}$. thick, normal-weight concrete in the core area and $7.75 \mathrm{in}$. thick normal-weight concrete outside the core.

The areas inside the core for other floors were framed with rolled structural steel shapes with welded shear studs acting compositely with 5 in. normal-weight concrete slabs.

The "W" in W27 beam denotes the shape of the beam, which is like the letter "I". The number following the "W" is the nominal depth of the beam in inches. The second number denotes the weight of the beam in pounds per linear foot. A W27 by 114 beam is $27.28 \mathrm{in}$. high and weighs $114 \mathrm{lb} / \mathrm{ft}$. 


\subsubsection{Floors 107 to 110}

A.t the top of each tower (floors 107 to the roof), a "hat truss" interconnected the core columns (Fig. 2-9). Diagonals of the hat truss were typically W12 or W14 wide flange members. In addition, four diagonal braces ( $18 \mathrm{in}$. by $26 \mathrm{in}$. box beams spanning the $35 \mathrm{ft}$. gap, and $18 \mathrm{in}$. by $30 \mathrm{in}$. box beams spanning the $60 \mathrm{ft}$. gap) and four horizontal floor beams connected the hat truss to each perimeter wall at the 108th floor spandrel. The hat truss was designed to provide a base for antennae atop each tower, although only the North Tower (WTC 1) antenna was actually built.
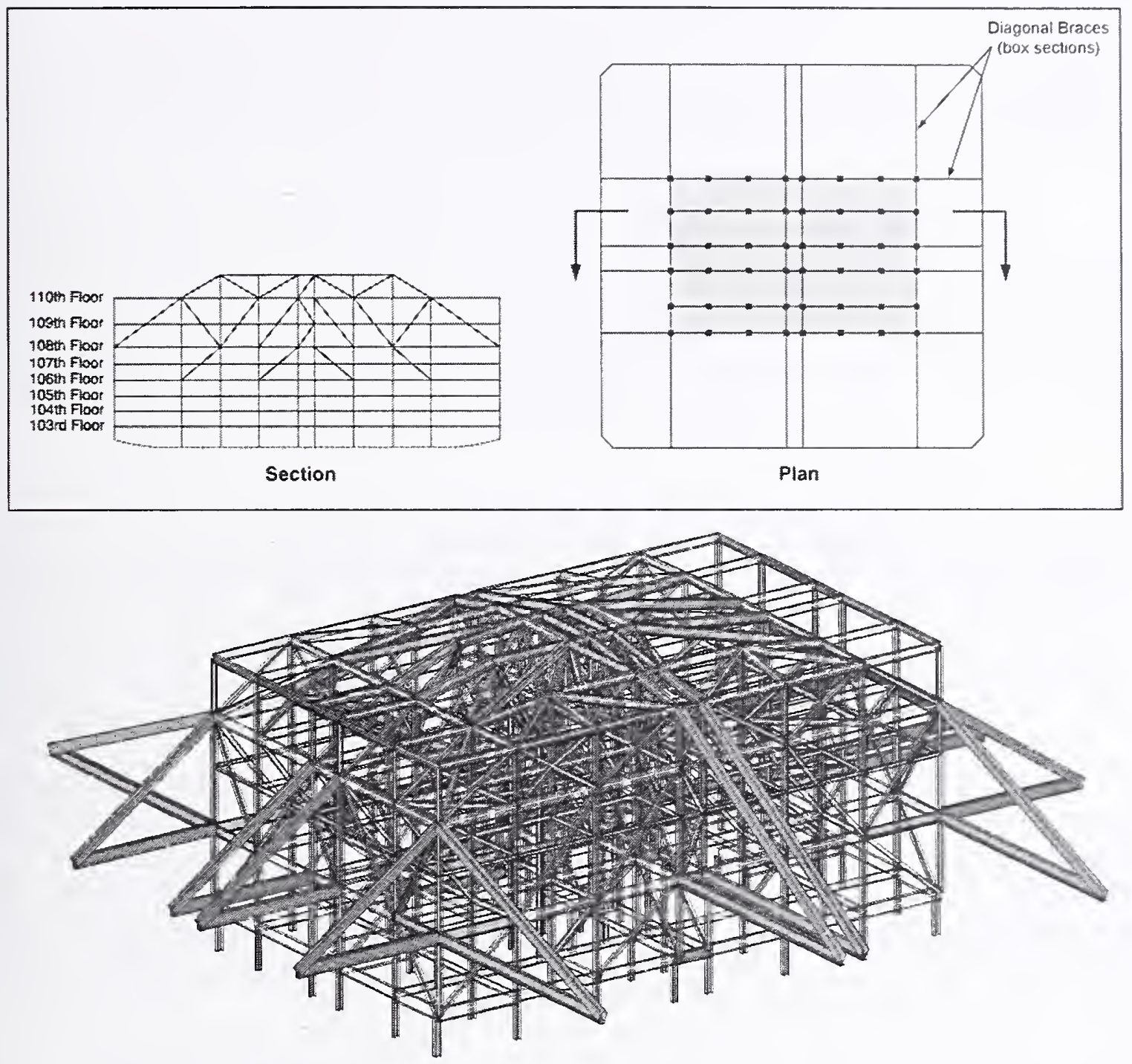

Figure 2-9. Hat truss in upper floors.

Perimeter columns for floors 107 to 110 also differed from the lower floors and were alternating small tube columns or wide flange columns, with the wide flange columns supporting the floor system. 


\subsubsection{Impact Zone}

The impact zones of the two towers were of particular interest, and special testing of the steels in this region was conducted. High-strain rate mechanical tests and high-temperature mechanical property tests focused on those steels most prominent in the impact zones, as indicated below.

In WTC 1, the perimeter columns torn out or otherwise damaged by the airplane impact (see Chapter 6) were predominantly specified as $55 \mathrm{ksi}$ and $60 \mathrm{ksi}$ steel. In WTC 2, the damaged columns ranged from $50 \mathrm{ksi}$ to $100 \mathrm{ksi}$, although most were specified in the $55 \mathrm{ksi}$ to $65 \mathrm{ksi}$ range. Core columns in the impact zonc of WTC 1 were almost entirely wide flange shapes. The core in the WTC 2 impact zone contained about equal numbers of box and wide flange columns, and 17 of the 49 core columns transitioned from box column to wide flange on these floors (Fig. 2-6). As is typical of all core columns, the steel was predominantly specified as $36 \mathrm{ksi}$ and $42 \mathrm{ksi}$ minimum yield strength.

\subsubsection{Floors Involved in Post-Impact Fires}

Special attention was given to characterizing the performance of the structural steel found in floors engaged in the post-impact fires. There were large fires on floors 92 through 100 and 104 in WTC 1 and floors 77 through 82 in WTC 2. In these floors, about 73 percent of the perimeter columns had strengths in the range $55 \mathrm{ksi}$ to $70 \mathrm{ksi}$, and most of the remainder from $75 \mathrm{ksi}$ to $100 \mathrm{ksi}$.

\section{$2.4 \quad$ REFERENCES}

SHCR (Skilling, Helle, Christiansen and Robertson). 1967. World Trade Center Structural Drawing Books. 


\section{Chapter 3 \\ CONTEMPORANEOUS STEEL SPECIFICATIONS}

\section{$3.1 \quad$ INTRODUCTION}

As is common practice, the structural engineering plans (obtained from the Port Authority of New York and New Jersey) only specify the minimum yield strengths and dimensions of the beams and columns. The steel contracts that the Port of New York Authority (PONYA or Port Authority) (PONYA 1967:Ch. 2) awarded for the fabrication provided specifications for the steels to meet those minimum yield strengths. Those contracts allowed the fabricators to use steels that conformed to certain ASTM International (ASTM) Standard Specifications including A 36, A 440, A 441 and A 514. Fabricators could also use certain proprietary steels from the major U.S. steel mills including the Bethlehem V-series and the United States Steel Ex-Ten series. These proprietary grades were required to conform to specific dated and published data sheets that the steel mills provided. Finally, the contracts also allowed other proprietary steels not listed in the contract, provided that the Port Authority chief engineer of the project reviewed and formally approved their specifications (PONYA 1967:

Section 203.100). It was by this third method that the Japanese steels were accepted for use. In all cases, extensive documentation was required for the steels to be acceptable.

This chapter focuses on the steels used in the area of the impact and fire: the floor trusses, the perimeter columns, the welded core box columns, and the rolled core columns, fabricated by Laclede, Pacific Car \& Foundry (PC\&F), Stanray Pacific, and Montague-Betts, respectively. It does not consider any of the sections of the buildings remote from the impact and fire sites, so fabricators of sections below the 9th floor (Mosher, Drier, Levinson, Pittsburgh-Des Moines. and Atlas) are not addressed. Table 3-1 summarizes some background information on the steel fabricators that worked on the upper stories of the towers. None of the four fabricating companies exist in the steel industry today.

In this document, "contemporaneous" refers to the standards in effect at the time of construction, in contrast to contemporary (or present-day) standards. ASTM standards are modified and renewed at regular intervals, so the current requirements of a standard may not have been in force during the World Trade Center (WTC) era. This distinction is also important because historical versions of standards can be difficult to locate. Although ASTM structural steel standards have evolved since the construction of the towers, the changes have been minor and do not represent changes to the basic mechanical properties of the steels.

\subsection{FLOOR TRUSSES}

Laclede Steel manufactured the trusses for the composite floor panels for both WTC 1 and WTC 2 from steel they made and rolled at their mill in Alton, Illinois. The chords were fabricated from hot-rolled angles, while the web was fabricated from hot-rolled round bar, Fig. 2-7. 
Table 3-1. Steel companies involved in WTC construction and their contracts.

\begin{tabular}{|l|l|l|c|}
\hline \multicolumn{1}{|c|}{ Fabricator } & \multicolumn{1}{|c|}{ Current Status } & \multicolumn{1}{c|}{ Component } & Tons \\
\hline Pacific Car \& Foundry Co. & Sold in 1974 & $\begin{array}{l}\text { Exterior columns and spandrels, } \\
\text { floors 9 to 107 }\end{array}$ & 55,800 \\
\hline Montague Betts Co., Inc & $\begin{array}{l}\text { No longer a steel } \\
\text { fabricator }\end{array}$ & $\begin{array}{l}\text { Rolled core columns and beams above } \\
\text { 9th floor }\end{array}$ & 25,900 \\
\hline $\begin{array}{l}\text { Pittsburgh-Des Moines Steel } \\
\text { Co. }\end{array}$ & $\begin{array}{l}\text { Bifurcation columns ("trees") 4th to } \\
\text { 9th floor }\end{array}$ & 6,800 \\
\hline Atlas Machine \& lron Works & No longer in business & $\begin{array}{l}\text { Box columns from 4th floor to the } \\
\text { bifurcation columns }\end{array}$ & 13,600 \\
\hline Mosher Steel Co. & Currently active & Core box columns below the 9th floor & 13,000 \\
\hline Stanray Pacific Corp. & Closed in 1971 & Core box columns above the 9th floor & 31,100 \\
\hline Levinson Steel Co. & $\begin{array}{l}\text { Sold in 1997, parent } \\
\text { company in bankruptcy }\end{array}$ & Supports for slabs below grade & 12,000 \\
\hline Laclede Steel Co. & $\begin{array}{l}\text { Bankrupt in 2001, new } \\
\text { owners of rolling mill }\end{array}$ & Floor trusses & Unknown \\
\hline Drier Structural Steel Co., Inc. & Unknown & Grillages & Unknown \\
\hline
\end{tabular}

Source: Feld 1971.

According to internal Laclede documents (Bay 1968), the top chord angles, as well as most round bars, were fabricated to meet ASTM A $242\left(F_{y}=50 \mathrm{ksi}\right)$. Only $1.09 \mathrm{in} .(27.7 \mathrm{~mm})$ and $113 / 16 \mathrm{in} .(46.0 \mathrm{~mm})$ round bars and the bottom chord angles were specified as ASTM A 36. Conversations with Laclede metallurgists (Brown 2002) active during the WTC construction revealed that for many components specified as ASTM A 36, Laclede supplied a higher-strength micro-alloyed steel with a typical $F_{y}=50 \mathrm{ksi}$, similar to a contemporary A 572 steel. National Institute of Standards and Technology (NIST) mechanical and chemical analyses (NIST NCSTAR 1-3D and 1-3E) have confirmed that this substitution was made in many cases.

\subsection{PERIMETER COLUMNS AND SPANDRELS}

PC\&F of Seattle, Washington, fabricated the perimeter wall panels. The perimeter panels were comprised of three important subassemblies: the columns, the spandrels, and the truss seats. The structural plans called for the columns to be fabricated from 14 grades of steel with $F_{y}=36,42,45,46$, $50,55,60,65,70,75,80,85,90$, and $100 \mathrm{ksi}$, although PC\&F received approval to upgrade all 85 and $90 \mathrm{ksi}$ steels to $100 \mathrm{ksi}$. Above the 75th floor, more than half of the columns had yield strengths between $55 \mathrm{ksi}$ and $70 \mathrm{ksi}$, inclusive. The spandrels were fabricated from twelve grades of steel with $F_{y}=36,42$, $45,46,50,55,60,65,70,75,80$, and $100 \mathrm{ksi}$ (again with all $85 \mathrm{ksi}$ steel upgraded to $100 \mathrm{ksi}$ ). The truss seats were specified to be fabricated from steel with $F_{y}=36 \mathrm{ksi}$ minimum.

Yawata Iron and Steel Co. (now part of Nippon Steel) supplied most of the steel to PC\&F for the perimeter columns and spandrels. In general, the exterior (or web) and side (or flange) plates of each column and the spandrels were fabricated from Japanese steel, and the interior web plate (plate 3) was fabricated from domestic steel (Symes 1969a; White 1969a). Searches of archival material yielded no information on the steels for the truss seats beyond the fact that they were specified as $F_{y}=36 \mathrm{ksi}$. 
During the 1960s, Yawata produced a number of named, proprietary grades (such as WEL-TEN and YAW-TEN series) of weldable steels with specified minimum properties. Several of these named grades supplied to PC\&F (WEL-TEN 60, WEL-TEN 62, WEL-TEN 80C) are eommon in the contemporaneous literature; open literature publications (Ito 1965a, 1965b; Goda et al. 1964) describe many of their physical and mechanical properties quite extensively. For two of the proprietary grades that Yawata supplied to PC\&F (WEL-TEN 60R and WEL-TEN 70), NIST has been unable to find eorroborating speeifieations or mechanical property data, even in eonsultation with Nippon Steel. It is possible that these names were assigned simply for convenience for the WTC construetion. Chemically, WEL-TEN 60, 60R and 62 are similar to eontemporary ASTM A 588, with their $\mathrm{Cr}$ additions and high silieon contents, though none would meet that speeification exaetly. WEL-TEN 60, 62, and 70 are heat-treated steels, while WEL-TEN 60R is a hot-rolled steel. WEL-TEN $80 \mathrm{C}$ is a steel eontaining chromium and molybdenum that is very similar to A 514 steels, and possibly eould have been manufactured to meet that speeifieation.

Contemporaneous documents indieate that PC\&F also purchased V-series (White 1968a, 2003) and modified V-series plate from Bethlehem Steel (Symes 1967a), EX-TEN and modified EX-TEN from U.S. Steel (Symes 1967a; White 2003; Barkshire 1968a), and various Kaisaloy grades (Barkshire 1968b) from Kaiser steel, for use in the interior plates. The interior plate (plate 3 - see Fig. 2-3) was usually half the thiekness of the flanges (when the flanges exceeded $0.5 \mathrm{in}$.), and never exceeded 15/16 in. thick, and so represents a small fraction (at most 5 pereent) of the mass of steel in the entire contraet. Status reports from mid-1968 indicate that PC\&F phased out U.S. Steel and Kaiser and replaeed them with Bethlehem as the only domestie supplier (Barkshire 1968e). Based on this information, it appears that most of the inner web plates in the columns near the impact floors were made from hot-rolled Bethlehem V-series steels.

\subsection{CORE-WELDED BOX COLUMNS}

Stanray Pacific Corp. fabricated the welded core columns above the 9th floor in both buildings. The plans called for two grades of steel with $36 \mathrm{ksi}$ and $42 \mathrm{ksi}$ minimum yield strengths. Contemporaneous documents (Morris 1967; Warner 1967) indicate that Stanray Paeific purchased at least 10,240 tons (of an estimated total eontract for 32,000 tons) of plate from Colvilles Ltd. (rolled in the Dalzell Works, Motherwell, Scotland). The rest of the plate (21,760 tons) came from Fuji Iron and Steel, Hirohata Works (Morris 1967; Warner 1967).

A mid 1967 doeument (Warner 1967) indicates that Fuji Steel supplied all plates thinner than 1.75 in. Both Fuji and Colvilles supplied plates 1.75 in and thieker, with Fuji supplying about 60 percent of the total mass of steel used. In the fire and impact floors of WTC 1 (94 to 98), only three of the columns are welded box columns, and all three were made from plate thinner than $1.75 \mathrm{in}$. In the fire and impact floors of WTC 2 (floors 78 to 84) only 9 of 52 welded box columns are made from plate 1.75 in or thieker. In terms of steel properties for modeling, the columns ean, therefore, be modeled with the properties of the Fuji-supplied plates alone.

\subsection{CORE-ROLLED WIDE FLANGE SHAPES}

Montague-Betts Steel fabricated all the rolled wide flange shapes for the core columns, as well as all the beams above the 9 th floor in both towers. These rolled shapes represent a significant fraction of the total 
core columns in the fire and impact zone. Above the 80th floor in WTC 2, more than half of the core columns were wide flange shapes, and above the 94th floor in WTC 1, 43 of the 46 columns were wide flange shapes. The plans called for steels with $36 \mathrm{ksi}, 42 \mathrm{ksi}, 45 \mathrm{ksi}$, and $50 \mathrm{ksi}$ minimum yield strengths, but very few of the rolled shapes used the $45 \mathrm{ksi}$ or the $50 \mathrm{ksi}$ material. Various sources (Davis 2002; Yawata 1969) confirm that Montague-Betts purchased about 12,000 tons (of a total contract of 25,900 tons) of A 36 and A 441 wide flange shapes from Yawata Iron and Steel, Sakai Works. An additional 1200 tons came from Dorman-Long, Lackenby Works, Middlesborough. England (Gallagher 1968; Goode 1967). Given the size of the Yawata contract, it is likely that it represents the majority, if not all, of the wide flange core columns. Montague-Betts CEO William Davis (2002), who worked on the project, confirmed that Montague-Betts also purchased steel from Bethlehem and U.S. Steel, the only two domestic mills that produced $14 \mathrm{~W}$ rolled sections heavier than $87 \mathrm{lb} / \mathrm{ft}$ (AISC 1973).

\subsection{FINDINGS}

Fourteen nominal strengths of steel were specified in the structural engineering plans, but only 12 strengths of steel (minimum yield strengths of $36,42,45,46,50,55,60,65,70,75,80$, and $100 \mathrm{ksi}$ ) were actually used in construction due to an upgrade of two steels ( 85 and 90 ksi steel upgraded to $100 \mathrm{ksi})$.

Ten different steel companies fabricated structural elements for the towers, using steel supplied from at least eight differcnt suppliers. Four fabricators supplied the major structural elements of the 9th to 107 th floors: Laclede Steel (floor trusses), PC\&F (perimeter column panels), Stanray Pacific (welded core box columns), and Montague-Betts (rolled core columns).

Although ASTM structural steel standards have evolved since the construction of the towers, the changes have been minor and do not represent changes to the basic mechanical properties of the steels.

\subsection{REFERENCES}

American Institute of Steel Construction (AISC). 1973. Manual of Steel Construction. New York: American Institute of Steel Construction.

Barkshire, A. 1968a. Internal SHCR report to J. White on fabrication at PC\&F. Contains five page attachment showing instances of U.S.S. steel used in columns mostly in floors 20 to 30 . Tower not specified. Seven pages. May 15.

Barkshire, A. 1968b. Internal SHCR to J. White showing spandrel plate of Kaisaloy 50-SG in panel 20316-19A. Six pages. December 4.

Barkshire. A. 1968c. Internal SHCR memo to J. White stating that USS and Kaiser are being phased out as suppliers with Bethlehem (Seattle) and Japanese mills furnishing all steel. Two pages with five pages attached. June 5.

Bay, R. D. 1968. Memorandum No. 11, Laclede internal memorandum showing grades of steel for bar joists, February 28. 
Brown. D. 2002. Telephone interview with Richard Fields. Brown, the Laclede mctallurgist during the WTC construction, confirmed that for ASTM A 36, Laclede would have specificd a microalloyed steel similar to current ASTM A 572. November 20.

Davis, W. 2002. Telephone interview with William Luecke. Montague Betts furnished rollcd bcams for the core of both towers as well as the antenna base for one tower. He remcmbered about 60 pcrcent of the steel was American. and the rest was Japanese or British. Confirmed that thcy did buy steel from Yawata, and that Yawata had better tolerances than the U.S. steel mills did. All records of the job were destroyed after 6 years. Montague Betts closed its steel operations in 1992. November 5.

Feld. L. S. 1971. Superstructure for the 1,350-ft World Trade Center. Civil Engineering-ASCE. 41:6670.

Gallagher, H. B. 1968. Internal PONYA memo W. Borland detailing inspection trip to Great Britain to visit Colvilles mills at Motherwell and Mossend, and Dorman-Long. May 15.

Goda, S., T. Ito, H. Gondo, I. Kimura, and J. Okamoto. 1964. Present status of weldable high strength steel, Yawata Technical Report (Yawata Seitetsu Kenkyu) 248:5086-5163.

Goode, B. 1967. Internal SHCR memo to Leslie Robertson on Worthington, Skilling, Helle, Jackson letterhead stating that Dorman-Long will produce 1,200 t of wide flange (W) sections for MontagueBetts. September 8.

Ito, T., K. Moriyama, and Y. Sogo. 1965a. Usability of WEL-TEN 80C welded joints of high-tension steel (in English). Yawata Technical Report (Yawata Seitetsu Kenkyu). 253:6307-6316.

Ito. T., K. Moriyama, and Y. Sogo, 1965b. Usability of WEL-TEN 80C Welded Joints of high-tension steel (In Japanese). Yawata Technical Report (Yawata Seitetsu Kenkıu). 253 6232-6244 (1965).

Morris, R. E. 1967. Letter from Stanray Pacific to R. M. Monti (PONYA) showing Colvilles (British Steel Export Assn.) and Fuji Steel as source of plate for contract. September 8.

Symes. R. C. 1967a. Memo from PC\&F to R. Monti (PONYA) requesting approval of Bethlehem $\mathrm{V}$-series steels outside of the published plate sizes. Two pages. Denied without full information on September 8, 1967, requested again with further documentation on November 2, 1967. Provisionally approved November 18, 1967 (no PCF letter \#). August 14.

Symes, R. C. 1969a. Memo from PC\&F to M Gerstman (Tishman) requesting adjustment to payment because of steel changes. States that plates 1,2, and 4 (flange, outside web, and spandrel) were made from imported steel (presumably Yawata) and plate 3 (inside web) was fabricated from domestic steel. Also contains a table showing tons of steel used by grade and thickness. 6 pages PCF\#T-40. February 5.

Warner. H. L. 1967. Memo from Stanray Pacific to Malcolm Levy (PONYA) detailing distribution of plate thicknesses between British and Japanese steels. Total is 32,000 tons. July 7.

White. James. 1968a. Memo from SHCR to RM Monti (Port Authority) approving PC\&F substitution of Fy $=100 \mathrm{ksi}$ steel for Fy $=90 \mathrm{ksi}$ steel in exterior columns. February 15. 
White, James. 1969a. Memo from SHCR to R. Monti (PONYA) documenting use of heat-treated steel above (PC\&F) and below (PDM) the 9th floor splice. Contains statement that plate 3 (inside web) was fabricated from domestic steel, while plates 1, 2, and 4 (flange, outside web, and spandrel) are imported steel. Also contains table that shows where ASTM 441-modified and WEL-TEN grades were used, by thickness and yield strength. 28 pages. July 28.

White, J. 2003. Telephone interview with William Luecke. PC\&F used (in addition to Yawata) U.S.S. and Bethlehem Steel for plates (probably for $F_{y}$ less than $60 \mathrm{ksi}$ ). February 11.

Yawata Iron and Steel Co. Ltd. 1969. New York World Trade Center Building. Internal Yawata document. 


\section{Chapter 4 \\ CONTEMPORANEOUS CONSTRUCTION SPECIFICATIONS}

\subsection{INTRODUCTION}

Chapter 3 traces the sources and grades of steel used to fabricate structural stcel componcnts for the World Trade Center (WTC) towers. This chapter extends further into the construction process, specifically adding information on the fabrication (wclding) of components and the erection of the buildings.

\subsection{FABRICATION OF THE VARIOUS COMPONENTS}

\subsubsection{Floor Trusses}

The web and the chord angles of the floor trusses (Fig. 2-8) were joined by resistance welding (Laclede 1969). Little information is available on the standards uscd for fabrication of the floor trusses; however, floor joist standards have existed since 1929. The American Institute of Steel Construction (AISC) Steel Construction Manual (1972) "Standard Spccifications for Open Web Steel Joists" specifies that $36 \mathrm{ksi}$ and $50 \mathrm{ksi}$ minimum yield strength steel are permitted in such bar joists and that "Joint connections and splices shall be made by attaching the members to one another by arc or resistance welding or other approved methods." A Technical Digest from the Steel Joist Institute (Somers 1980) also confirms the use of resistance welding.

\subsubsection{Exterior Wall Columns and Spandrels}

A Welding Design and Fabrication article (1970a) describes the fabrication sequence of the perimeter columns. The fabrication began with forming the inside wall of the modules using a butt joint to link the spandrel plates to the inner column webs, followed by the addition of the sides and outer face of the columns by six simultaneous submerged arc welds. Pacific Car and Foundry (PC\&F) constructed a 16-station automated production line to keep up with the schedule of 55,800 tons of perimeter column panels between November 1967 and August 1970, an average of 1,400 tons per month.

The construction contract states that the submerged arc electrodes used in the WTC were purchased to the requirements of ASTM Standard A 558 "Specification for Bare Mild Steel Electrodes and Fluxes for Submerged Arc Welding." This Standard was withdrawn in 1969, and was replaced by an equivalent American Welding Society (AWS) Standard A 5.17 "Bare Mild Steel Electrodes and Fluxes for Submerged Arc Welding." The period 1965 to 1969 was one of transition, during which AWS assumed the responsibility of maintaining the standards for welding filler materials. Because the contract was awarded in 1967, the fabrication was likely started with the requirements of the 1965 version of the ASTM International (ASTM) Standard (ASTM A 558-65T, jointly published by AWS as AWS A 5.17-65T), but later perimeter column panels may have included some minor changes associated with the conversion to the 1969 version of the AWS Standard (AWS A 5.17-69). 
Distorted columns were straightened in the conventional manner by heating just after column assembly. Such trcatment can result in minor changes in properties.

The inner wall assembly (the spandrels and inner plates of the perimeter column panels) was joined with full penetration welds according to the requirements of AWS D 2.0 "Specifications for Welded Highway and Railway Bridges." This probably refers to the 1966 version of AWS D 2.0. This standard may have been chosen over D 1.0 "Code for Welding in Building Construction" because, at the time, D 1.0 was limited to steel strengths under $60 \mathrm{ksi}$ (Fenton 1966). AWS D 2.0 specifies various dimension and strength requirements for the assemblies and their welds (e.g. paragraph 302 and 403). This standard, like most standards, lagged behind the steel technology of the time. Thus, it seems to be mostly designed around the application of fairly old stcels like A 7, A 36, and A 373.

Once the inner wall was ready, the columns were assembled from side platcs, butt plates, diaphragm plates, and flange plates (Welding Design 1970a). Once assembled and prehcated, the plates were joined in the main fillet weld gantry, a station that made six $0.75 \mathrm{in.}(19 \mathrm{~mm})$ fillet welds simultaneously along the length of the perimeter column panel. Then. the module was jacked 90 degrees, and the other six fillet welds were made along the length of the panel. At full production, this gantry laid down $2,900 \mathrm{lb}$ $(1,300 \mathrm{~kg})$ of weld metal a day. These large fillet welds started $6 \mathrm{in}$. $(150 \mathrm{~mm})$ from the ends of the columns, so manual welding was used to finish the welding of the ends as well as to make any repairs.

\subsubsection{Core-Welded Box Columns}

To fabricate the core box columns, Stanray Pacific, like PC\&F, used large assembly fixtures and triple submerged arc welding stations to achieve high production rates. Correspondence generated during the initial stages of the fabrication showed the level of attention to welding and inspection details needed to meet the requirements of Port of New York Authority (PONYA or Port Authority) and Skilling, Helle, Christianscn, \& Robertson (SHCR) as described below.

A September 1967 draft of the contract between PONYA and The United States Testing Laboratory (a third-party inspector) lists the documentation that would be required of the work at Stanray Pacific Corp (White 1967c). This contract prescribes daily and weekly written reports of components that were accepted, those that were rejected, and a summary of any problems, with copies going both to the construction manager and to SHCR. In addition, a weekly report was sent with all the chemical and physical (mechanical) tests performed. The inspectors checked the various steps from plate delivery (checking heat number, specification conformance, and condition), through fabrication (alignment, 100 percent visual inspection of the welds, and selection of regions for non-destructive testing), to final inspection (perpendicularity of milled ends, overall length, cleaning, and marking). PONYA also had a procedure to inspect the steel from all sources. The procedure included double-checking the mill certificates by performing a tensile test and a check analysis on one out of ten heats selected at random (Monti 1967b). The requirements were still higher for steel with strengths above $50 \mathrm{ksi}$ or from foreign sources. The welding procedures, welders, and welding operators were required to be qualified in accordance with requirements of Appendix D of AWS Codes D1.1-66 and D 2.0-66. The welding electrodes for manual metal arc welding conformed to ASTM A 233-64T, E60 and E70 series (also AWS A 5.1-64T). Mild steel electrodes and fluxes for submerged arc welding conformed to ASTM A 588-65T (also AWS A 5.17-65T) and to Sec. 1.17.3 of the AISC Specification for Structural Steel Buildings. 
By October 1967, welders were being qualified, magnetic particle inspector qualification was being discussed (bascd on a minimum of $40 \mathrm{~h}$ of training), and chemical analysis of the stcel was underway (Chauncr 1967a). The level of inspector oversight continued to increase until by November 10, 1967 "U.S. Testing inspectors are all over the place and recording a lot of information" (Chauner 1967b). The level of attention to detail increased even morc after a surprise visit to Stanray by Hugh Gallagher, a PONYA inspector, on November 20, 1967 (Gallagher 1967).

While rcading the correspondence, onc senses that toward the beginning of the contracts, the various fabricators faced major (and perhaps unexpected) challenges introduced by both the tight production schedule and PONYA and SHCR's strict quality requirements.

\subsubsection{Connections (Bolts and Welds)}

The Port Authority contract allowed the use of ASTM A 307, A 325, and A 490 fasteners. The WTC Design Standards book (p. DS1-6) calls for the use of ASTM A 325 bolts with no indication of type. According to the standard, they would have been supplied as Type 1. As in the contemporary version of ASTM A 325, Type 1 bolts in 1970 had $F_{y}=120 \mathrm{ksi}$ for diameters up to and including $1 \mathrm{in}$, and $F_{y}=105 \mathrm{ksi}$ for larger diameters. ASTM A 325-70 differs significantly from the current ASTM A 325-02 in several ways. In particular, the specification for Type 2 bolts was withdrawn in 1991. ASTM A 325-02 also admits three new chemistries for Type 1 bolts. In ASTM A 325-02, the specification for Type 1 Carbon Steel bolts most closely approximates the Type 1 bolts of A 325-70.

Spandrels of adjacent perimeter column panels were connected with high-strength bolted shear connections. Adjacent spandrels were butted to each other with splice plates on the inside and outside (Fig. 2-3). For floors 9 to 107, each spandrel was connected to the splice plates with anywhere from 6 to 32 bolts, depending on design load. Splice plates were all $36 \mathrm{ksi}$ steel regardless of spandrel grade. Bolts for all connections between spandrels conformed to ASTM A 325. Minutes of a May 1967 (Feld 1967a) meeting between PC\&F, PONYA, and Koch, state that no A 490 bolts were to be used for the spandrel splice plates, and that only A 325 bolts were to be used there.

Perimeter columns were bolted via the butt plates to those immediately above and below, with four bolts in the upper stories and six bolts in the lower stories. Other than at the mechanical floors, panels were staggered (Fig. 2-5) so that only one-third of the units were spliced in any one story. At the top and bottom of the mechanical floors, every column contained a splice, and columns were welded together as well as bolted.

Seats for the trusses that supported the floor were welded to spandrels in the perimeter column panels and to channels attached to core columns. At the core, trusses were bolted to the seats. At the perimeter, the trusses were positioned on the seats and held in place at the perimeter with construction bolts, and then welded to the seats. The construction bolts generally remained in place after welding.

\subsubsection{Construction (On-Site Assembly)}

During fabrication, Karl Koch Erecting Co. used a combination of bolting, shielded metal arc (SMA) welding (E7018), and gas metal arc welding (semiautomatic Fab Co 71 with $\mathrm{CO}_{2}$ shielding) to join the components (Welding Design 1970b). The E7018 low-hydrogen SMA electrode would likely have been 
produced to ASTM Standard A 233-64T (also published by AWS as A 5.1-64T), then AWS

Standard A 5.1-69 for the later parts of the fabrication. The 3/32 in. (2.4 mm) diameter Fab Co 71 (sic, probably should be FabCO 71, a trademark of Hobart Brothers Company) was an E70T-1 flux cored arc electrode and would likely have been produced according to ASTM A 559 (withdrawn in 1969), then AWS A5.20-69. Higher-strength SMA electrodes (ASTM A 316 until 1969, then AWS A 5.5-69) were also permitted by the contract. More than $48,000 \mathrm{lb}(22,000 \mathrm{~kg})$ of electrodes were used in each of the towers (Welding Design 1970b). Koch used a combination of visual and ultrasonic inspection on the joints. They estimated that rework would cost threc times as much as the original weld, so they inspected early and often to minimize any rework. One reason that rework was so expensive is that some welds took as many as 200 passes, so they wanted to catch any problems before the later passes made access more difficult.

Perhaps the most common construction standard for buildings of the period was AWS D 1.0 "Welding in Building Construction" (Fenton 1966). This document was subject to frequent revisions by the responsible committee. Some versions that may have been specified for parts of the WTC towers were the versions published in 1966, 1967, and 1968. The 1967 and 1968 revisions addressed issues such as the details on the use of multiple-electrode submerged arc welding, more requirements on qualification of the welders (especially tack wclders), and the addition of radiographic inspection. Many of these revisions may have been driven by the needs of the WTC design. Since the D2.0 code referenced in the discussion on fabrication of perimeter column panels above only covered the use of submerged arc and shielded metal arc welds (unless through special application of Sec. 5), usc of D1.0 (specifically through the use of Sec. 502) might have been the easiest way to cover the use of FabCO 71 electrode.

Examination of the perimeter columns shipped to National Institute of Standards and Technology revealed arc welds at the ends of the trusses, where they were attached to the columns during erection. These welds were probably produced by gas metal arc or shielded mctal arc electrodes.

\subsection{REFERENCES}

American Institute of Steel Construction (AISC). 1972. Standard specifications and load tables for open web steel joists, longspan steel joists, deep longspan steel joists. New York: American Institute of Steel Construction.

Chauner, R. 1967a. Internal SHCR memo to James White. October 27.

Chauner, R. 1967b. Internal SHCR memo to James White. November 10.

Feld, L. S. 1967. Internal PONYA memo to H. Tessler summarizing meeting between PC\&F, Koch, Tishman, SHCR, and PONYA to discuss engineering changes. Discusses spandrel plate splices, A 325 bolts, not using A 490 bolts for the spandrel splices, and a statement by N. Soldano (PC\&F) that Yawata would furnish imported steel with $F_{y}>36 \mathrm{ksi}$, and Kawasaki would furnish $36 \mathrm{ksi}$ steel. Five pages. May 9.

Fenton, E. A. 1966. Code for welding in building construction. New York: American Welding Society.

Gallagher, H. 1967. Internal PONYA memo to D. Brown. December 11. 
Laclede Steel. 1968. Standard Resistanee and Are Weld Conneetions used in Truss Manufaeture. February 28.

Monti, R. M. 1967b. Memo to R. Morris (Stanray Paeific). November 13.

PONYA (Port of New York Authority) 1967. "The World Trade Center Contract WTC-217.00 Fabricated Steel Box Core Columns and Built-up Beams from the 9th Story Splice to the Penthouse Roof, North and South Towers." Chapter 2 "Materials." Sections 201-203. Contract between Stanray Pacific Corp and PONYA. May 18.

Somers, R. E. and T. V. Galambos. 1980. Welding of Open Web Steel Joists. Technieal Digest No. 8. Steel Joist Institute Richmond, Va. Based on inclusion of statisties on U.S. joist produetion in 1979.

Welding Design and Fabrieation. 1970a. Welding and fabrieating 55,000 tons of steel for the World Trade Center, July:50-52.

Welding Design and Fabrication. 1970b. Welding and inspecting the World Trade Center-giant among giants, February:53-56.

White, J. 1967c. Memo to PONYA. September 1. 
This page intentionally left blank. 


\section{Chapter 5 \\ STEEL INVENTORY AND IDENTIFICATION}

\subsection{THE RECOVERY OF WORLD TRADE CENTER STRUCTURAL STEEL}

Beginning in October of 2001, nearly a year prior to the start of the National Institute of Standards and Technology (NIST) Investigation, members of the Federal Emergency Management Agency (FEMA) American Society of Civil Engineers (ASCE) Building Pcrformance Assessment Team (BPAT), members of the Structural Engineers Association of New York (SEAoNY), and Professor A. Astaneh-Asl of the University of California, Berkeley (with support from the National Science Foundation), began work to identify and collect World Trade Center (WTC) structural steel from the various recovery yards where debris, including the steel, was taken during the WTC site clean-up effort. Dr. J. Gross, a rescarch structural engineer at NIST and a member of the FEMA/ASCE Building Performance Study, was involved in these early efforts.

There were four major sites where debris from the WTC buildings was shipped during the clcan-up effort:

- Hugo Neu Schnitzer, Inc., Fresh Kills Landfill in Staten Island, New Jersey,

- Hugo Ncu Schnitzer East, Inc., Claremont Terminal in Jersey City, New Jersey,

- Metal Management, Inc., in Newark, New Jersey, and

- Blanford and Co. in Keasbey, New Jersey.

The volunteers searched through enormous unsorted piles of steel and other debris for pieces from the WTC buildings, specifically searching for (McAllister 2002):

- Exterior column panels and interior core columns from WTC 1 and WTC 2 that were exposed to fire and/or impacted by the aircraft,

- Exterior column panels and interior core columns from WTC 1 and WTC 2 directly above and below the impact zoncs,

- Badly burned pieces from WTC 7 ,

- Connections from WTC 1, 2, and 7 (e.g., seat conncctions, single shear plates, and column splices),

- Bolts in all conditions,

- Floor trusses including stiffeners, seats, and other components,

- Any pieces that in the engineers' professional opinion might be useful. 
Once selected for recovery, the samples were marked as "SAVE" and given an alphanumeric code that identified the recovery yard where they were located and an accession number. Some pieces were not saved in their entirety, but instead, small portions were removed, hereafter called coupons and held at Gilsanz Murray Steficek, LLP (GMS). Coupons were also removed in the field for WTC 5 and held at GMS (all coupons were later sent to NIST).

Facing concern that the selected steel may not be properly preserved in the recovery yards, NIST arranged for the steel to be shipped to its campus located in Gaithersburg, MD, starting in February of 2002, about six months before launching its investigation.

Before the samples were shipped to the NIST campus, environmental testing for asbestos and analysis of the paint for lead was conducted. SEAoNY volunteers and NIST personnel continued to select and ship steel specimens to NIST through October 2002. Mr. S. Cauffman of NIST coordinated all environmental testing, transportation, and delivery of the recovered steel to NIST. The recovered structural components constituted the material base for analysis in the NIST Investigation.

Structural steel elements were also collected and held by the Port Authority of New York and New Jersey (PANYNJ or Port Authority) in Hangar 17 of John F. Kennedy International Airport. The main goal of the Port Authority project was to decontaminate and preserve the steel, as well as other WTC artifacts, for future exhibits and memorials. A complete listing of the pieces held by PANYNJ can be found in the Preservation and Inventory Report prepared by Voorsanger and Associates Architects, PC (Voorsanger 2002). NIST personnel visited the hangar and identified 12 pieces considered important to the Investigation. Six whole pieces were moved to the NIST campus in Gaithersburg, Maryland, as well as portions of six additional pieces.

\section{$5.2 \quad$ STRUCTURAL ELEMENTS RECOVERED FROM WTC BUILDINGS}

\subsubsection{Location and Labeling of Structural Steel Elements}

NIST obtained 236 samples from the WTC buildings. The report Steel Inventory and Identification (NIST NCSTAR 1-3B) gives a complete list of each sample with a brief description and characteristic photographs. The samples ranged from full exterior column panels to pieces of bolts and bags of glass and other debris fragments. The pieces were classified into one of eight categories:

\section{$\underline{\text { Classification }}$}

Exterior column panel sections (flat wall or corner)

"Bow-tie" pieces

Rectangular built-up box column (not perimeter column)

Wide flange sections

Floor trusses

Channels

Coupons from WTC 5

Miscellaneous (isolated bolts, floor hanger components, other)

\section{\# of Pieces}

94

2

11

44

23

25

7

30 


\subsubsection{Identification Methods of WTC Structural Steel Elements}

Information from Leslie E. Roberts Associates (LERA) indicated that all structural steel picces in WTC 1 and WTC 2 were uniquely identificd by stampings (rccessed lettcrs and numbers) and/or painted stcncils (Faschan 2002). NIST was successful in finding thesc markings on many of the perimeter panel scctions, core columns, and other wide flange members, thercby identifying the original, as-built location of the pieces. (Based on identification of damaged panels in precollapse photographs, NIST belicvcs that the asbuilt locations were correctly identificd; for the majority of identified pieccs, however, it is the intended location within the building that was identified.)

The positive identification of the structural elements was made possiblc by deciphcring the stampings and/or stencils found on them. During fabrication, the exterior panel sections were stamped at the bottom of the center column on the inside face. These stampings indicated the building, center column linc number, and floors spanned by the columns. The core columns werc stamped at the lower end of the component. The building was typically represented as "A" for WTC 1 and "B" for WTC 2. An examplc of a stamping found on an exterior column is shown in Fig. 5-1, where the stamping indicates that the piece was from WTC 2 with center column line number of 206, spanning floors 83-86. Core columns were found to have similar markings as seen in Fig. 5-2. Other stampings found on the flanges of the perimeter columns indicated the column type (individual plate dimensions) as well as the specified minimum yield strength of the column. Additional stampings were sometimes located on the flanges, although NIST, PANYNJ, and LERA were unable to determine the significance of these codes. All stampings were typically located within one meter of the bottom of the column.

The perimeter panels and core columns were often additionally stenciled in white or yellow lettering with similar building information. For the exterior panel sections, the stenciling was located on or near the lowest spandrel on the interior face. Figure 5-3a shows typical stenciling found on a perimeter panel, indicating this piece was in WTC 1 with center column line number of 130 , spanning floors 93 to 96 . For the core columns, both stenciling and hand written codes were observed on the recovered pieces.

Figure 5-3b shows one of these stencilings from a core column located in WTC 1.

Also seen in Fig. 5-3a are two other markings, "5T" and " $<63>$ ", found on the exterior panel sections. These markings are the estimated piece tonnage ( 1 ton equals 2,000 lbs, or approximately $907 \mathrm{~kg}$ ) and erector's derrick division number, respectively. This information was also stamped on some of the core column pieces, see Fig. 5-2. The erector, Karl Koch Erecting Co., Inc., assigned derrick divisions 47 through 70 for WTC 1 and derrick divisions 547 through 570 for WTC 2 (PONYA 1967). Each division was assigned to a specific area of the building and shared one of four cranes with other nearby derrick divisions. For example, a single crane may have lifted pieces from derrick divisions 65,67 , and 69. Several derrick divisions that hoisted the specific columns for both buildings have been identified, based on derrick numbers found on structural elements with positive identification, providing additional information to help identify partially identified panels (NIST NCSTAR ]-3B). 

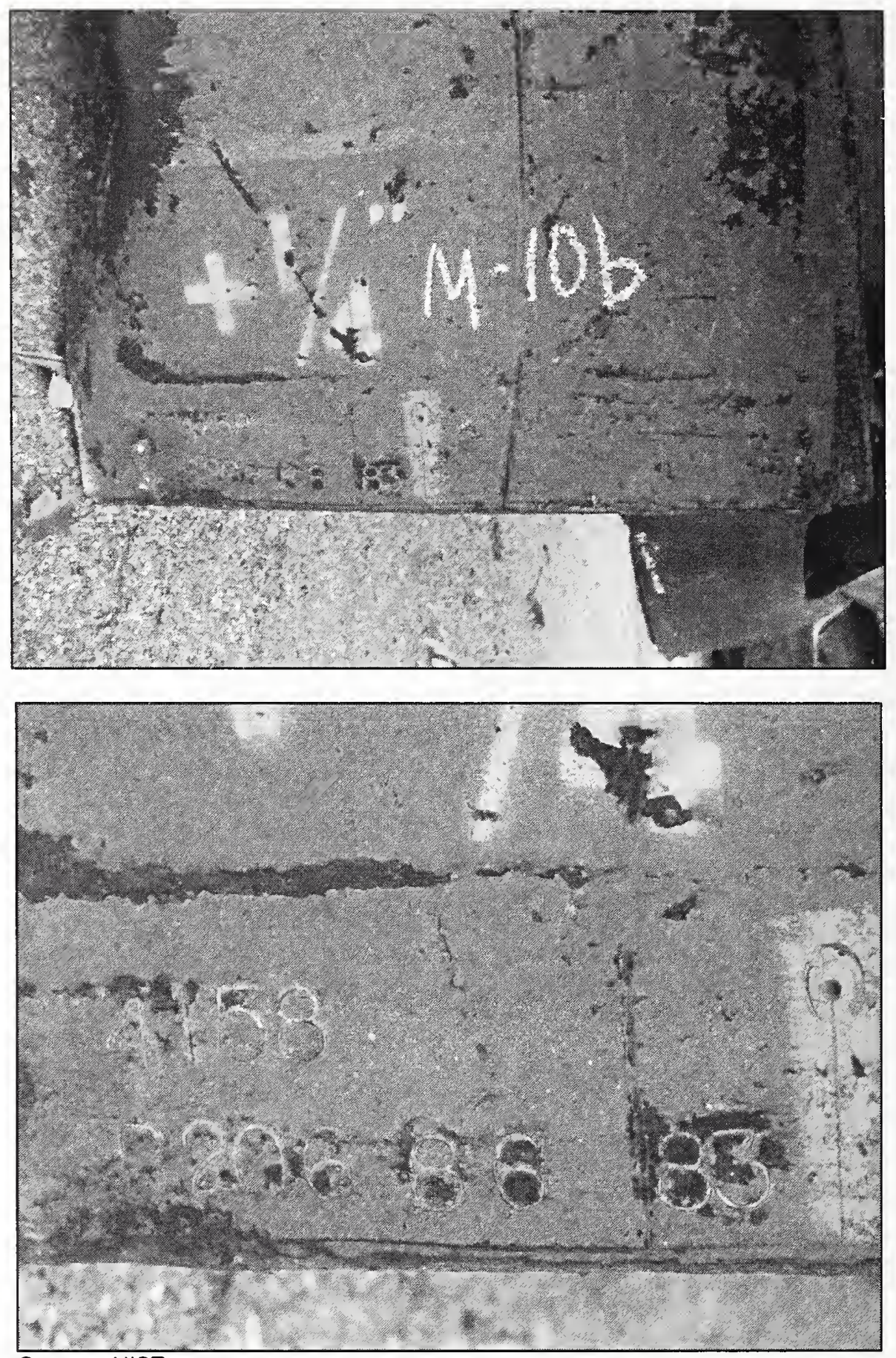

Source: NIST.

Figure 5-1. Example of stampings on the interior base of the middle column for each panel. Shown here on panel M-10b are the stampings "B206 8683 ," indicating that it is from WTC 2, column number 206, spanning floors 83 to 86 . 


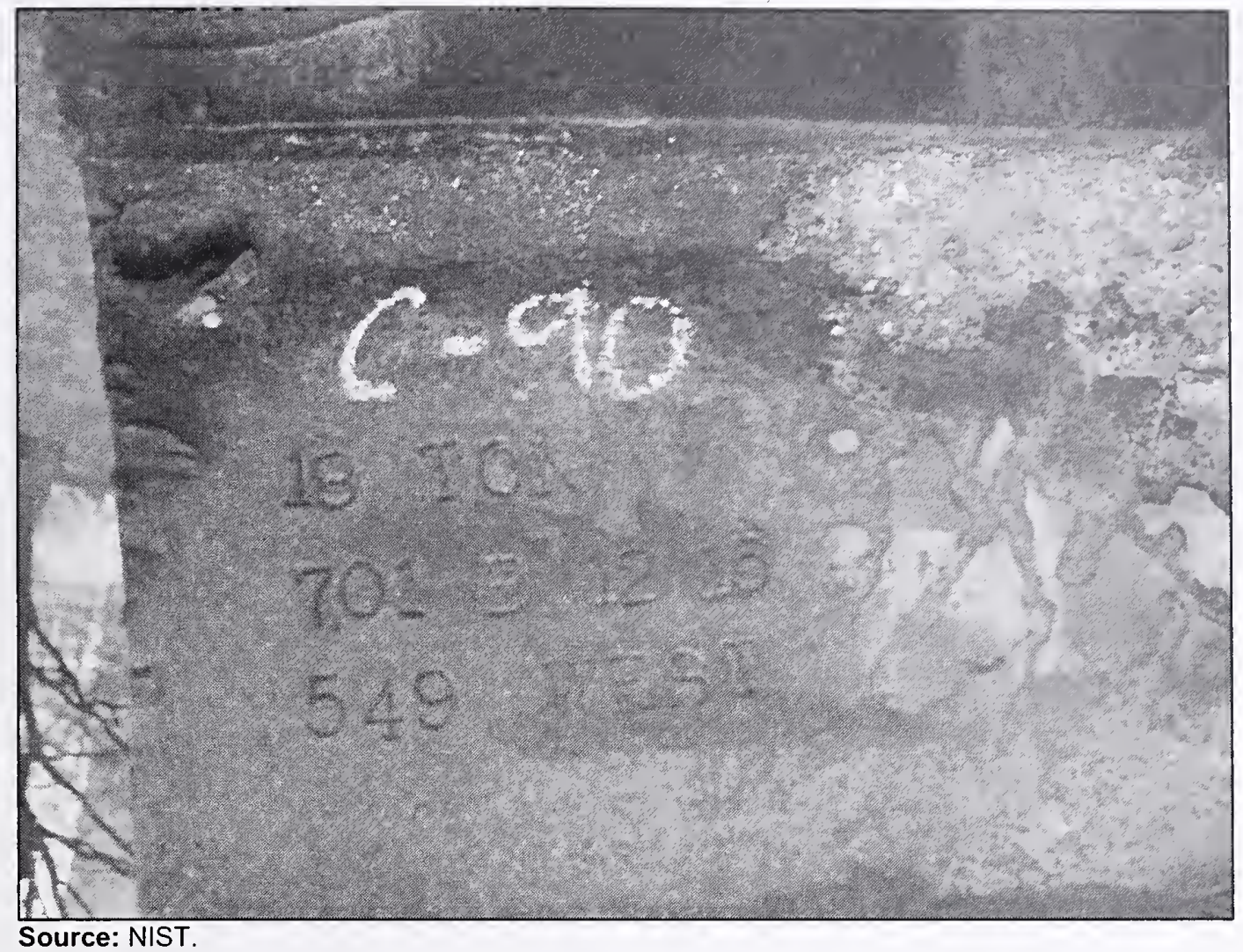

Figure 5-2. Example of stampings placed on one end of a core column. Shown here on sample C-90 are the stampings "18 TON, 701 B $12-16,549$ WEST," indicating that it is from WTC 2, core column number 701, and spans floors 12 to 16 . Also indicated are the approximate weight of the piece (18 tons) and the derrick division <549> that was to lift it into place. 

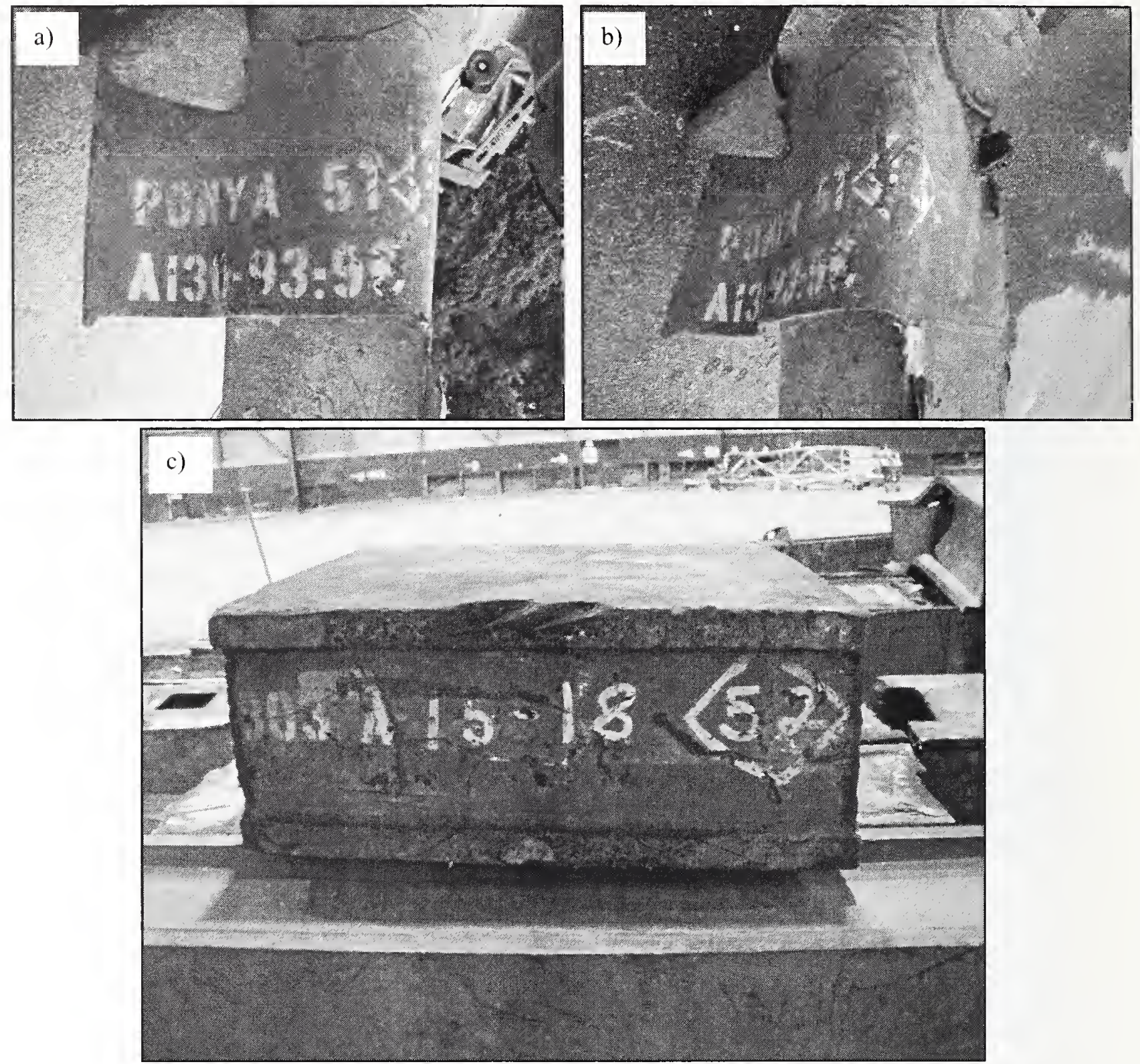

Source: NIST.

Figure 5-3. a) and b) Characteristic stenciling found on the lower portions of the exterior column panels for sample M-27. Markings indicate this piece was in WTC 1, column number 130 , spanning floors 93 to 96 . Also seen are two other indicators, "5T" and " $<63>$," indicating the estimated piece weight in tons and erector's derrick division number, respectively. c) Characteristic stenciling found on core column for sample B-6152-1. Markings indicate this piece was in WTC 1, column number 803, spanning floors 15 to 18 with a derrick division number of $<52>$. 


\subsubsection{Identified Perimeter Panels}

Of the 94 pieees of recovered perimeter panel, 90 panels are distinet. The other four pieces of perimeter column had become separated from their main panels during salvage and were subsequently labeled C-13a, C-16a, C-28b, and K-16a. Of the 90 panels, 42 distinet exterior eolumn panels have been unambiguously identified, and one has been partially identified. Table 5-1 lists the fully identified panels with Fig. 5-4 showing the relative loeation of those identified exterior panels within the top third of the buildings. Significantly more pieees were reeovered from WTC 1 than WTC 2.

Table 5-1. Identified perimeter column panel pieces from WTC 1 and WTC 2.

\begin{tabular}{|c|c|c|c|c|c|}
\hline $\begin{array}{l}\text { NiST } \\
\text { Name }\end{array}$ & Description & Bldg & Column & Floors & $\begin{array}{l}\text { Derrick } \\
\text { Division }\end{array}$ \\
\hline ASCE-2 & One full column & WTC 2 & 330 & $40-43$ & $\mathrm{NA}$ \\
\hline B-1024 & Full panel & WTC 2 & 154 & $21-24$ & NA \\
\hline B-1043 & Full panel & WTC 2 & 406 & $40-43$ & NA \\
\hline B-1044 & Full panel & WTC 2 & 409 & $40-43$ & NA \\
\hline $\mathrm{C}-10$ & Full panel & WTC 1 & 451 & $85-88$ & $5 \mathrm{x}$ \\
\hline $\mathrm{C}-13$ & Rectangular column with spandrel & WTC 2 & 200 & $90-92$ & 569 \\
\hline$C-13 a$ & Partial of single column & WTC 2 & 159 & $90-92$ & 569 \\
\hline $\mathrm{C}-14$ & 1 column, lower $1 / 3$ & WTC 2 & 300 & $85-87$ & 570 \\
\hline $\mathrm{C}-18$ & 3 columns, bottom $2 / 3$ & WTC 2 & 230 & $93-96$ & NA \\
\hline $\mathrm{C}-22$ & 3 columns, lower $1 / 2$ & WTC 1 & 157 & $93-96$ & 69 \\
\hline $\mathrm{C}-24$ & 3 columns, upper $1 / 3$ & WTC 2 & 203 & $74-77$ & NA \\
\hline $\mathrm{C}-25$ & 1 column, lower $1 / 2$ & WTC 1 & 206 & $89-92$ & 69 \\
\hline $\mathrm{C}-40$ & 2 columns, lower $2 / 3$ & WTC 1 & 136 & $98-101$ & $6 x$ \\
\hline $\mathrm{C}-46$ & Nearly full panel & WTC 2 & 157 & $68-71$ & 569 \\
\hline $\mathrm{C}-48$ & Nearly 2 full columns & WTC 2 & 442 & $91-94$ & NA \\
\hline $\mathrm{C}-55$ & 1 column, lower $1 / 3$ & WTC 1 & 209 & $94-97$ & NA \\
\hline $\mathrm{C}-89$ & 2 full columns & WTC 2 & 215 & $12-15$ & NA \\
\hline $\mathrm{C}-92$ & 1 column, lower $1 / 3$ & WTC 2 & 130 & $93-96$ & NA \\
\hline $\mathrm{C}-93$ & 1 column, lower $1 / 3$ & WTC 1 & 339 & 99-102 & NA \\
\hline $\mathrm{CC}$ & 2 full columns & WTC 1 & 124 & $70-73$ & NA \\
\hline $\mathrm{K}-1$ & 3 columns, lower $1 / 3$ & WTC 1 & 209 & $97-100$ & NA \\
\hline $\mathrm{K}-2$ & 1 column, lower $2 / 3$ & WTC 1 & 236 & $92-95$ & NA \\
\hline M-2 & Full panel & WTC 1 & 130 & $96-99$ & 63 \\
\hline M-10a & 3 columns, middle section $1 / 3$ & WTC 2 & 209 & $82-85$ & NA \\
\hline $\mathrm{M}-10 \mathrm{~b}$ & 3 columns, lower $1 / 2$ & WTC 2 & 206 & $83-86$ & 569 \\
\hline M-20 & 2 columns, lower $1 / 3$ & WTC 1 & 121 & $99-102$ & 63 \\
\hline M-26 & Full panel & WTC 1 & 130 & $90-93$ & $6 \mathrm{x}$ \\
\hline $\mathrm{M}-27$ & 2 columns, lower $3 / 4$ & WTC 1 & 130 & $93-96$ & 63 \\
\hline M-28 & 3 columns, lower $1 / 4$ & WTC 2 & 345 & $98-101$ & NA \\
\hline $\mathrm{M}-30$ & 2 columns, lower $1 / 3$ & WTC 1 & 133 & 94-97 & 65 \\
\hline
\end{tabular}




\begin{tabular}{|l|l|c|c|c|c|}
\hline $\begin{array}{c}\text { NIST } \\
\text { Name }\end{array}$ & \multicolumn{1}{|c|}{ Description } & Bldg & Column & Floors & $\begin{array}{c}\text { Derrick } \\
\text { Division }\end{array}$ \\
\hline N-1 & 2 full columns & WTC 1 & 218 & $82-85$ & NA \\
\hline N-7 & Full panel & WTC 1 & 127 & $97-100$ & NA \\
\hline N-8 & Full panel & WTC 1 & 142 & $97-100$ & 67 \\
\hline N-9 & Nearly full panel & WTC 1 & 154 & $101-104$ & 69 \\
\hline N-10 & 2 columns, lower 2/3 & WTC 1 & 115 & $89-92$ & 6 x \\
\hline N-12 & 2 full columns & WTC 1 & 206 & $92-95$ & 69 \\
\hline N-13 & 3 columns, lower 1/3 & WTC 1 & 130 & $99-102$ & 63 \\
\hline N-99 & Nearly full panel & WTC 1 & 148 & $99-102$ & 67 \\
\hline N-101 & Full panel & WTC 1 & 133 & $100-103$ & 65 \\
\hline S-1 & 2 columns, lower 1/3 & WTC 1 & 433 & $79-82$ & 47 \\
\hline S-9 & Full panel & WTC 1 & 133 & $97-100$ & NA \\
\hline S-10 & 2 columns, lower $1 / 2$ & WTC 1 & 224 & $92-95$ & NA \\
\hline S-14 & Full panel & WTC 2 & 218 & $91-94$ & 557 \\
\hline
\end{tabular}

Key: NA, information not available.

Note: " $\mathrm{x}$ " in the derrick division column indicates an unreadable number.

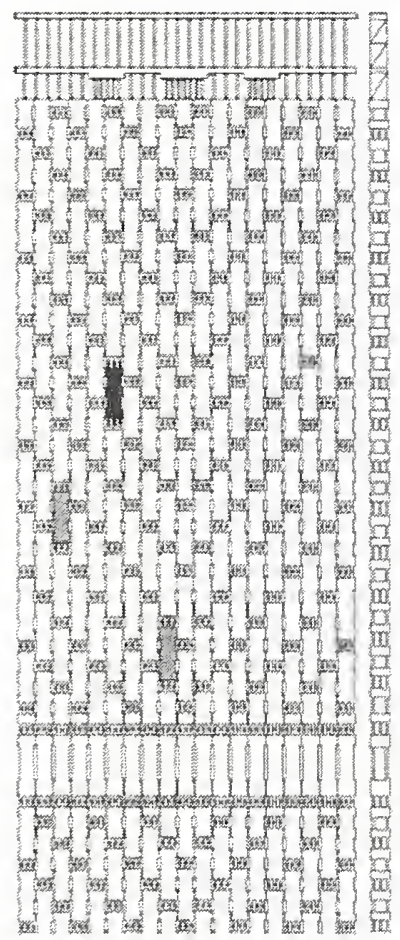

400 series

WTC 1 West face

WTC 2 South face

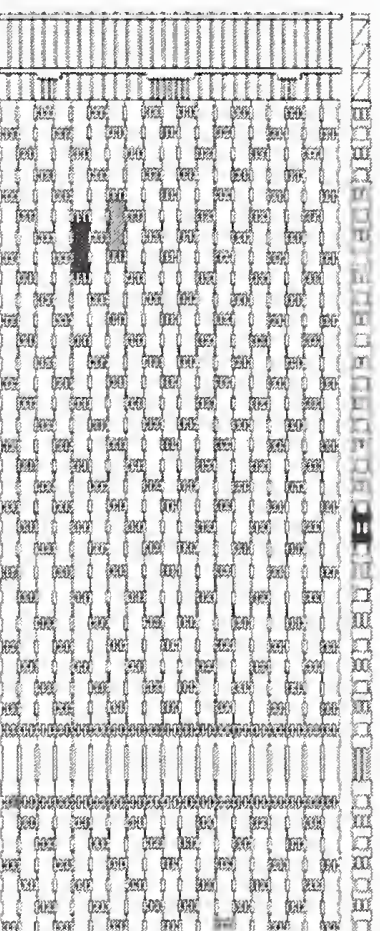

300 series

WTC 1 South face

WTC 2 East face

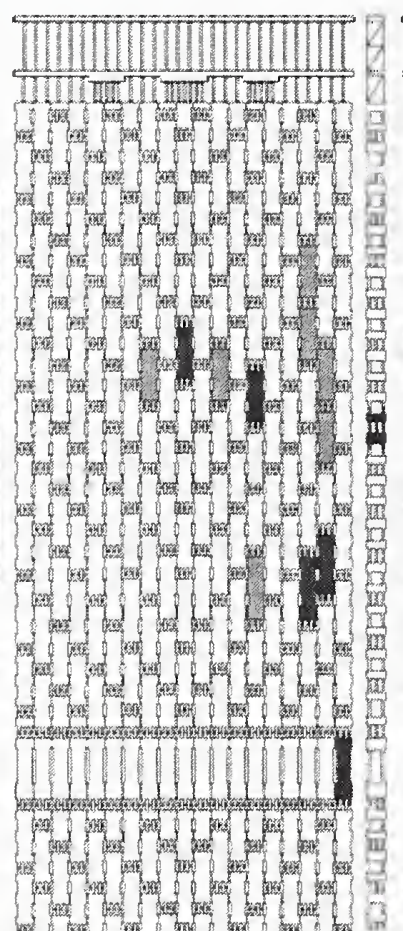

200 series

WTC 1 East face

WTC 2 North face

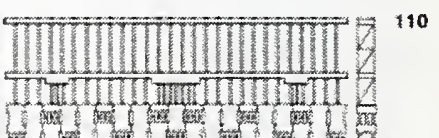

105

100

95 90
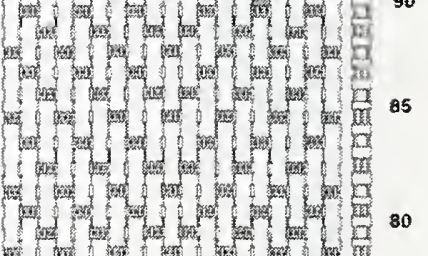

1.

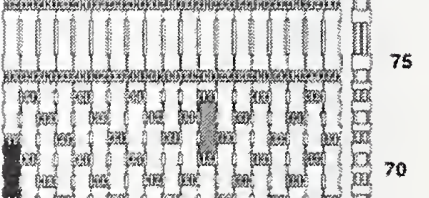

100 series

WTC 1 North face

WTC 2 West face

Figure 5-4. Location of the exterior panels recovered from the top third of the WTC towers. Recovered WTC 1 panels are shown in light shading/green and WTC 2 panels are in dark shading/blue. 
Of the 42 positively identificd cxterior panels, 25 had spccific markings giving all the information nccded (building, column, floors) to locate the structural clcment within the buildings from onc or both codes (i.e., stampings or stencils). The flangc stampings, which indicated the specificd yicld strength and column type, were used to confirm the findings (NIST NCSTAR 1-3B). The only deviation notcd was that $100 \mathrm{ksi}$ steel was substitutcd for grades that werc specificd as $85 \mathrm{ksi}$ and $90 \mathrm{ksi}$. This observed substitution is consistent with Port Authority documcnts from the construction period indicating that $100 \mathrm{ksi}$ steel was used for all stecl specificd as 85 or $90 \mathrm{ksi}$ (NIST NCSTAR 1-3A).

Sixteen other panels were identified through analysis of flange and web thickness and identifying marks in the partial stampings and stenciling lcgible on the panel. Thesc markings included various combinations of specified minimum yicld strength, column typc, and derrick division numbers.

The 42 identified pancls include thrce panels from the mechanical floors and two panels from the corners of the buildings. The idcntification process and complete documentation of all panels are detailed in NIST NCSTAR 1-3B.

\subsubsection{Identified Core Columns}

Table 5-2 lists the 12 core columns that have bccn positively identified. An additional sample, C-83, is also listed in this group. Though no markings were found on the piece, the shape and dimensions of this sample conform to the design drawings for core columns and have a similar appearance to core column C-90. In addition, there were 13 pieces of wide flange sections that have stampings or markings, although NIST, PANYNJ, and LERA were unable to determine the significance of these codes. These pieces are believed to be floor beams or other non-column pieces, which were not numbered in a systematic way; indeed, these pieces may not even be from the towers.

Table 5-2. Identified pieces of core column material from WTC 1 and WTC 2.

\begin{tabular}{|l|c|l|l|c|c|c|c|}
\hline NIST Name & Type $^{\mathbf{a}}$ & \multicolumn{1}{|c|}{ Description } & Bldg & Column & Floors & $\begin{array}{c}\text { Derrick } \\
\text { Division }\end{array}$ & $\begin{array}{c}F_{y^{\prime}} \\
\text { (ksi) }\end{array}$ \\
\hline B-1011 & RB & Heavy rectangular column & WTC 1 & 508 & $51-54$ & 55 & 36 \\
\hline B-6152-1 & RB & Heavy rectangular column & WTC 1 & 803 & $15-18$ & 52 & 36 \\
\hline B-6152-2 & RB & Heavy rectangular column & WTC 1 & 504 & $33-36$ & 51 & 36 \\
\hline C-83 & RB & Heavy rectangular column & NA & NA & NA & NA & NA \\
\hline C-88a & RB & Heavy rectangular column & WTC 2 & 801 & $80-83$ & 550 & 42 \\
\hline C-88b & RB & Heavy rectangular column & WTC 2 & 801 & $77-80$ & 550 & 42 \\
\hline C-90 & RB & Heavy rectangular column & WTC 2 & 701 & $12-15$ & 549 & 36 \\
\hline C-30 or S-12 & W & Wide flange section & WTC 2 & 1008 & $104-106$ & NA & 36 \\
\hline C-65 or S-8 & W & Wide flange section & WTC 1 & 904 & $86-89$ & 52 & 36 \\
\hline C-71 & W & Wide flange section & WTC 1 & 904 & $77-80$ & NA & 36 \\
\hline C-80 & W & Wide flange section & WTC 1 & 603 & $92-95$ & 51 & 36 \\
\hline C-155 & W & Wide flange section & WTC 1 & 904 & $83-86$ & 52 & 36 \\
\hline HH or S-2 & W & Wide flange section & WTC 1 & 605 & $98-101$ & 53 & 42 \\
\hline
\end{tabular}

a. $\mathrm{RB}$ is a rectangular box column consisting of four welded plates; $\mathrm{W}$ is a rolled wide flange shape.

b. C-83 was not positively identified, but due to similar size and shape was deemed a core column.

Key: NA, information not available. 
Of the 12 identified core columns, all but two were clearly marked. Sample C-30 had markings that clearly indicated the building and column, howevcr, the floors were partially obscured: "x04 - 10x." As the $24 \mathrm{ft}$ section had both connector ends, it spanned only two floors and fit with the floor levels of 104-106. The second incompletely marked sample was C-88b which did not have any stampings or markings, but was welded to C-88a (identified by stampings).

\subsubsection{Other Structural Pieces}

Floor trusscs were also recovered; however, attempts to identify their specific as-built locations within the buildings wcre not successful because no stampings were found. Of the 23 pieces held by NIST, eight were of significant size but were badly tangled and twisted as a result of the collapse and subsequent handling. The remaining pieces consisted of shorter sections of chord and rod material in addition to welded sections that connected the trusses to the floor seats.

Seven samples were recovered from WTC 5 (NIST NCSTAR 1-3B). These are coupons that were removed at the WTC site and held by GMS, LLP. They were subsequently sent to NIST once the Investigation officially began.

No structural elements have been positively identified from WTC 7. However, the columns were fabricated from conventional $36 \mathrm{ksi}, 42 \mathrm{ksi}$, and $50 \mathrm{ksi}$ steel produced to ASTM specifications.

\subsection{STRUCTURAL STEEL ELEMENTS OF SPECIAL IMPORTANCE}

Of the 42 exterior column panels and 12 core columns that were positively identified, many were considered especially important to the NIST Investigation. Two major categories of steel are considered to be of special value:

- Samples located in or around the floors impacted by the airplanes,

- Samples that represent one of 14 grades of steel specified for the exterior columns, one of four grades of steel specified for the core columns, or one of the two grades of steel for the floor trusses.

\subsubsection{Samples Located in or around the Floors of the Airplane Impact}

Photographic evidence indicated that damage to WTC 1 due to aircraft impact occurred from the 94th to 99th floors and was bounded by columns 111 through 152. For WTC 2, the impact arca was lower, with damage found from the 77 th to 85 th floors. While the damage appeared to be bounded by column lines 411 and 440, the starboard wing of the aircraft may have struck columns even closer to the southeast corncr of the building. This area was persistently obscured by smoke, however, and no clear images were available. From this information, NIST was able to determine which perimeter panels and core columns could be used to comment on damage (physical and fire) and possible failure mechanisms in this area. Fig. 5-5a shows an ovcrlay of the recovered exterior panels in and around the impact zone of WTC 1. Samples C-80 and $\mathrm{HH}$, both core columns, were also identified as residing near the impact zone. The recovered portion of each column is approximately represented in this image. No similar impacted exterior panels were recovered for WTC 2; however, two core columns were recovered, Fig. 5-5b. 


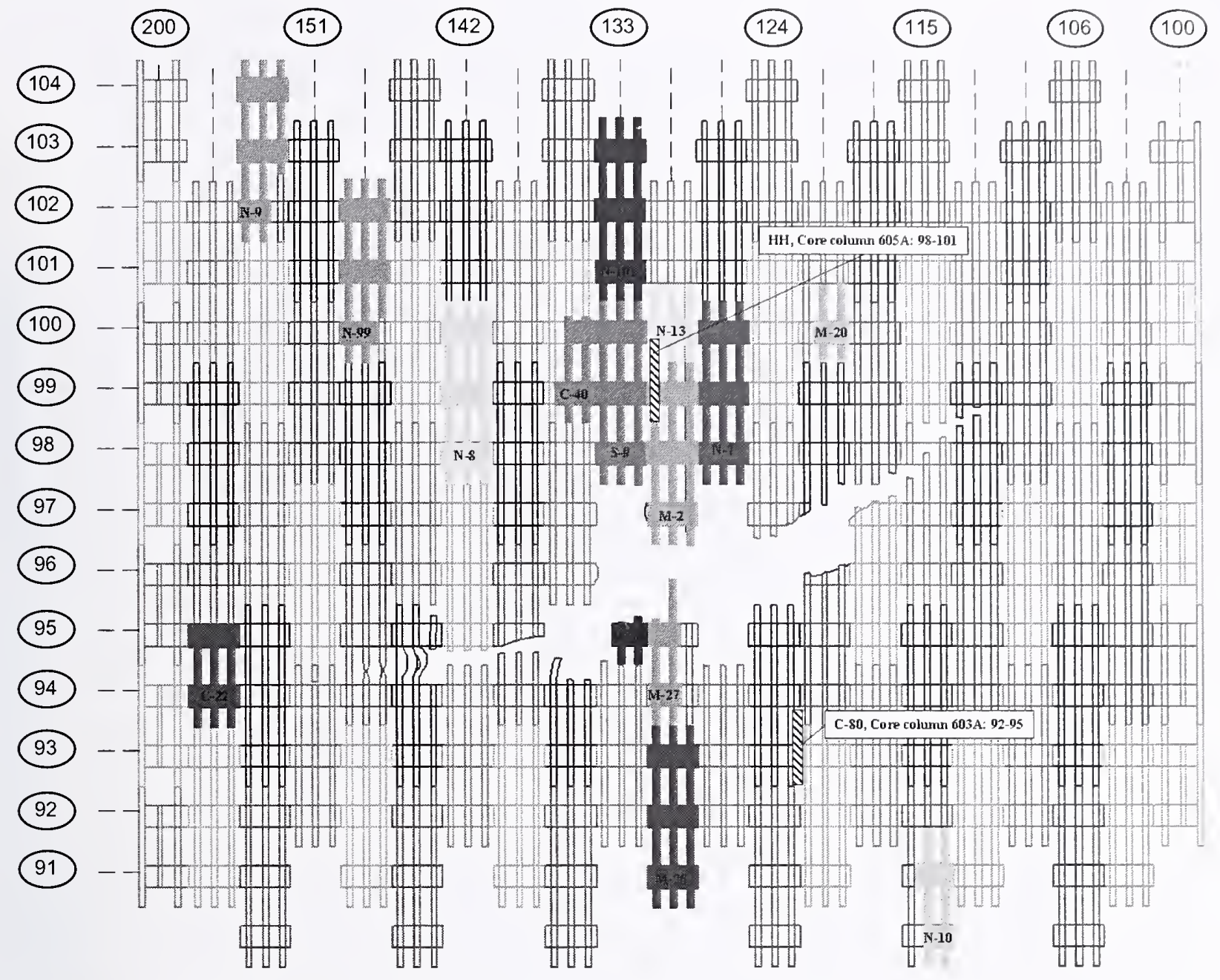

Figure 5-5a. Interpreted column damage, from photographic evidence, to north face of WTC 1, with overlay of recovered steel identified by NIST. Colored regions represent recovered portions. Both core columns (\#603 and \#605) are in the second row from the north face of WTC 1. 


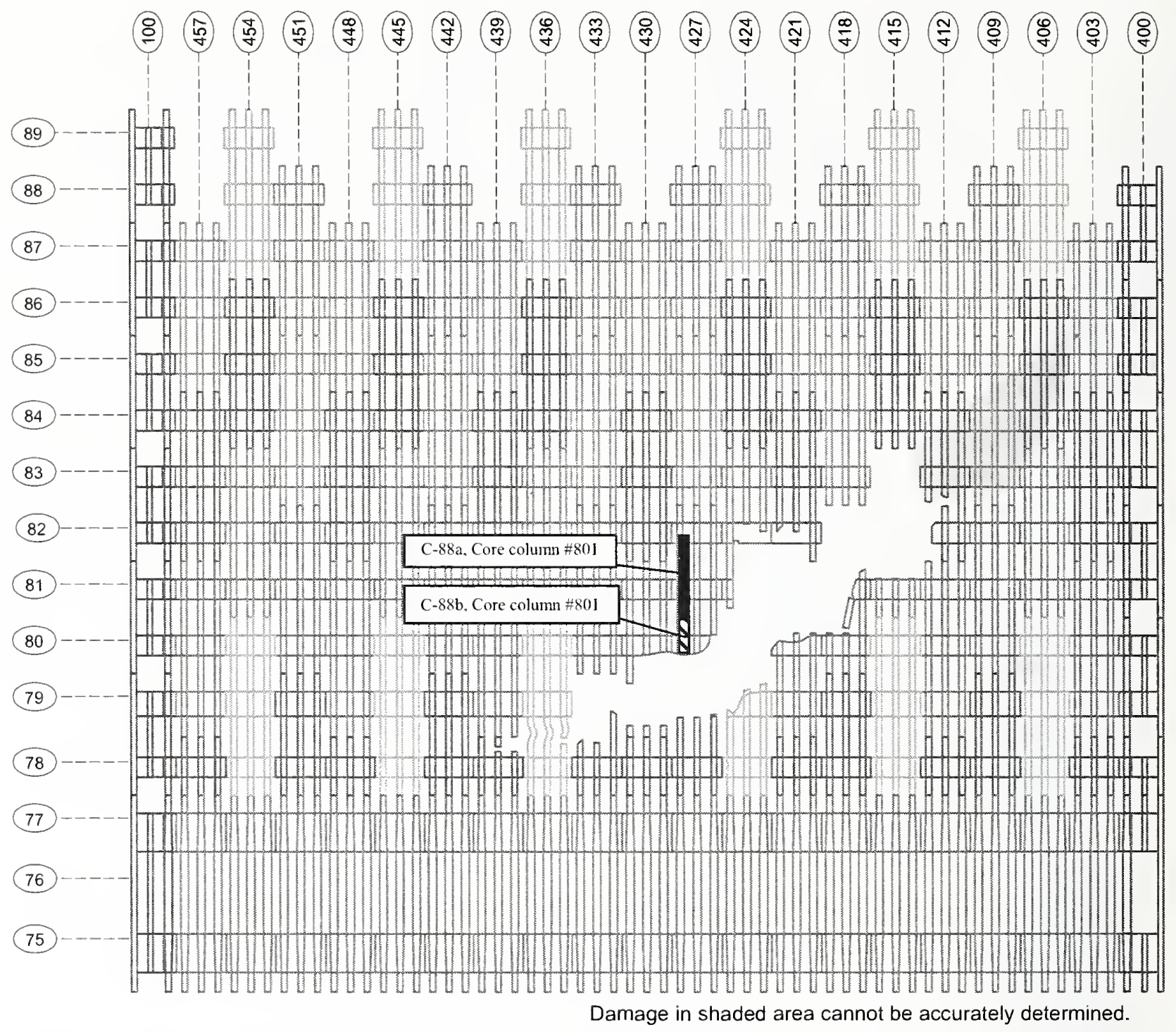

Figure 5-5b. Interpreted column damage, from photographic evidence, to south face of WTC 2, with overlay of recovered steel identified by NIST. Samples shown represent recovered portions. Core column line 801 is in the row closest to the south face of WTC 2.

\subsubsection{Samples Representing the Various Types of Steel Specified in the Design Drawings}

The other class of samples important to the investigation included representative samples of the different strengths of steel specified for the buildings. From the recovered steel, sufficient representative samples from each important class of steel were available for a full examination (i.e., chemical, metallurgical, and mechanical property analyses) to provide data for modeling the behavior of the towers during impact through collapse. Detailed information can be found in NIST NCSTAR 1-3B. Considering both column and spandrel material, samples of all strengths specified for the perimeter panels were available. While only two ( $36 \mathrm{ksi}$ and $42 \mathrm{ksi}$ ) of the four grades of steels were recovered for the core columns (Table 5-2), 
99 percent of core columns wcre fabricated from these two gradcs. Samples of floor truss could not bc identified as to their precise, as-built location within the buildings; however, chemical and mechanical property analyses showed that both specified grades of stcel wcre recovered.

\subsection{SUMMARY}

NIST has 236 samples from the WTC buildings, with the vast majority belonging to WTC 1 and WTC 2. These samples represent roughly 0.25 percent to 0.5 percent of the 200,000 tons of structural steel used in the two towers. The collection of steel from the WTC towers was sufficient for determining the quality of the steel and, in combination with published literature, for providing mechanical propertics as input to models of building performance. The original as-built location of 42 recovered perimeter pancls and 12 recovered core columns were determined. Representative samples exist for all 12 grades of perimeter panel material, two grades of the core column material (representing 99 percent of the total number of columns), and both grades of the floor truss matcrial. Furthermore, a number of structural pieces were recovered from locations in or near the impact and fire damaged regions of the towers, including four exterior panels directly hit by the airplane and three core columns located near these areas.

\subsection{REFERENCES}

Faschan, W. 2002. Leslic E. Robertson Associates, Ncw York City, NY, personal communication to F. Gayle, National Institute of Standards and Technology, Gaithersburg, MD, May 21.

McAllister, T., ed. 2002. World Trade Cemter Building Performance Study: Data Collection, Preliminary Observations, and Recommendations. FEMA Report 403. Federal Emergency Management Agency. Washington, DC, May.

Voorsanger and Associates Architects, PC. 2002. WTC Arclives Interim Storage Facility, JFK International Airport: Preservation and Inventory Report, Draft 2. New York City, NY, November. 
This page intentionally left blank. 


\section{Chapter 6 \\ DAMAGE AND FAILURE ANALYSIS OF STRUCTURAL STEEL}

\subsection{BACKGROUND}

Damage characteristics, failure modes, and fire-related degradation of the recovered structural stcel components from the World Trade Center (WTC) towers are important in:

1. Ascertaining the response of the structural steel of the towers to the impact of the plancs;

2. Providing information on pcrimeter column damage for correlation with impact damage modelcd in the aircraft impact damage analysis;

3. Providing information on thcrmal excursions experienced by the structural steel for use in the reconstruction of thermal and tenability environment. (The model of the fire was not intended to match the actual fire on a column by column basis, and thus the observations on thermal excursions of the steel are not cxpected to match the model in detail); and

4. Providing input to the National Institute of Standards and Technology (NIST) structural fire response and collapse analysis covering observations of missing fire proofing on the perimeter columns due to airplane impact. This information is vital as fire proofing was the primary factor determining whether fire exposed steel reached temperatures where there was significant strength loss. In addition, NIST used the detailed charactcrization of damage observations as a base for modeling the damaged towers and the subsequent collapse of the buildings.

To document the damage to the structural steel of the towers, two sets of observations were made:

1. Pre-collapse analysis concentrating on impact damage sustained by the exterior panel sections. This analysis was conducted using photographic and video images of the towers and was limited to the perimeter panels as the interior structural components (e.g., core columns, floor trusses) could not be clearly observed. The photographic and vidco images were also used to determine the location of pre-collapse fires and possible firc-related damage to the panels.

2. Damage characteristics of the recovered structural steel elements. The exterior panels were again evaluatcd, as wcll as the connectors or seat asscmblies used to attach the floor trusses to the exterior column panels, the inner core columns, and the seat assemblies attached to the channels of the core columns. Of particular importance were the samples from locations near the airplane impact region (north face of WTC 1 and south face of WTC 2) and those where fire was known to exist before the collapse of the buildings.

This information is summarized below, and the complete analysis is found in the report Damage and Failure Modes of Structmal Steel Components (NIST NCSTAR 1-3C). 
While the physical damage and failure mechanisms were reported for the present condition of the steel, in most cases it was difficult to conclude which extreme loading event may have led to the condition. Observed damage may have been a result of the aircraft impact, the pre-collapse fires, the ensuing collapse of the buildings, post-collapse fires, or the subsequent handling related to the recovery efforts. In particular, it was difficult to separate degradation from the relatively brief fire exposure experienced prior to the collapse of the buildings from the fire exposure in the debris pile at the WTC site, which for some samples was as long as 4 months.

\subsection{OBSERVABLE PRE-COLLAPSE DAMAGE OF EXTERIOR COLUMN PANELS}

Photographic images, video images, engineering drawings, and other relevant resources were used to determine pre-collapse damage to the exterior column panels. Through this analysis, impact damage, failure modcs, and possible exposure to fire of the panels prior to the collapse of the towers was established. The analysis focused primarily on the perimeter panels since damage to the core columns and floor trusses prior to collapse could not be discerned from pre-collapse images.

\subsubsection{Photographic Analysis of Pre-Collapse Damage to Exterior Panels}

Multiple photographs were meshed together, with extensive image processing, to produce detailed images of impact damage for both WTC 1 and WTC 2. Figure 6-1 (top) shows a resulting image of WTC 1. An outline of a Boeing 767 aircraft was superimposed and distorted to approximately match the outline of the hole in the building, Fig. 6-1 (bottom). Further, markers denote observable failure modes in the exterior columns. The specific failure modes identified include bolt failure, weld failure, and tearing of the steel plates. For visualization purposes, the black lines on the image indicate the location of the bolted column splices. Of the 42 recovered panels with known as-built locations, five from WTC 1 had been directly impacted by the airplane or had damage as a result of the impact. These are the NIST labeled panels M-30, S-9, M-27, M-2, and N-7 shown in Fig. 6-1 (bottom). Damage features and failure modes of these five panels and individual components of the panels have been documented in NIST NCSTAR 1-3C.

The availability of images with details of the impact hole in WTC 2 was much more limited than for WTC 1 (refer to NIST NCSTAR 1-5A). This was primarily due to gcography, where the land area south of the WTC complex was much less extensive than to the north, and tall buildings to the south made it difficult to get clear views. In addition, most of the professional and amateur photographers who moved toward the area came from the north and did not try to go south of the WTC complex. Fig. 6-2 (top) shows one of the few images where smoke shrouded only a portion of the damage to WTC 2 caused by the airplane impact. In Fig. 6-2 (bottom), markers were again added to identify observable failure modes in the exterior columns. The damaged region encompassing the starboard wing tip area (outlined roughly in yellow) was unobservable in all available photographs and video footage due to the large and persistent volume of smoke emitted from those floors. For visualization purposes, the black lines indicate the location of the bolted column joints in the exterior wall. Detailed post-collapse analysis of the failures was not possible around the impact hole in WTC 2 because no identified panels in NIST's possession came from this area. 

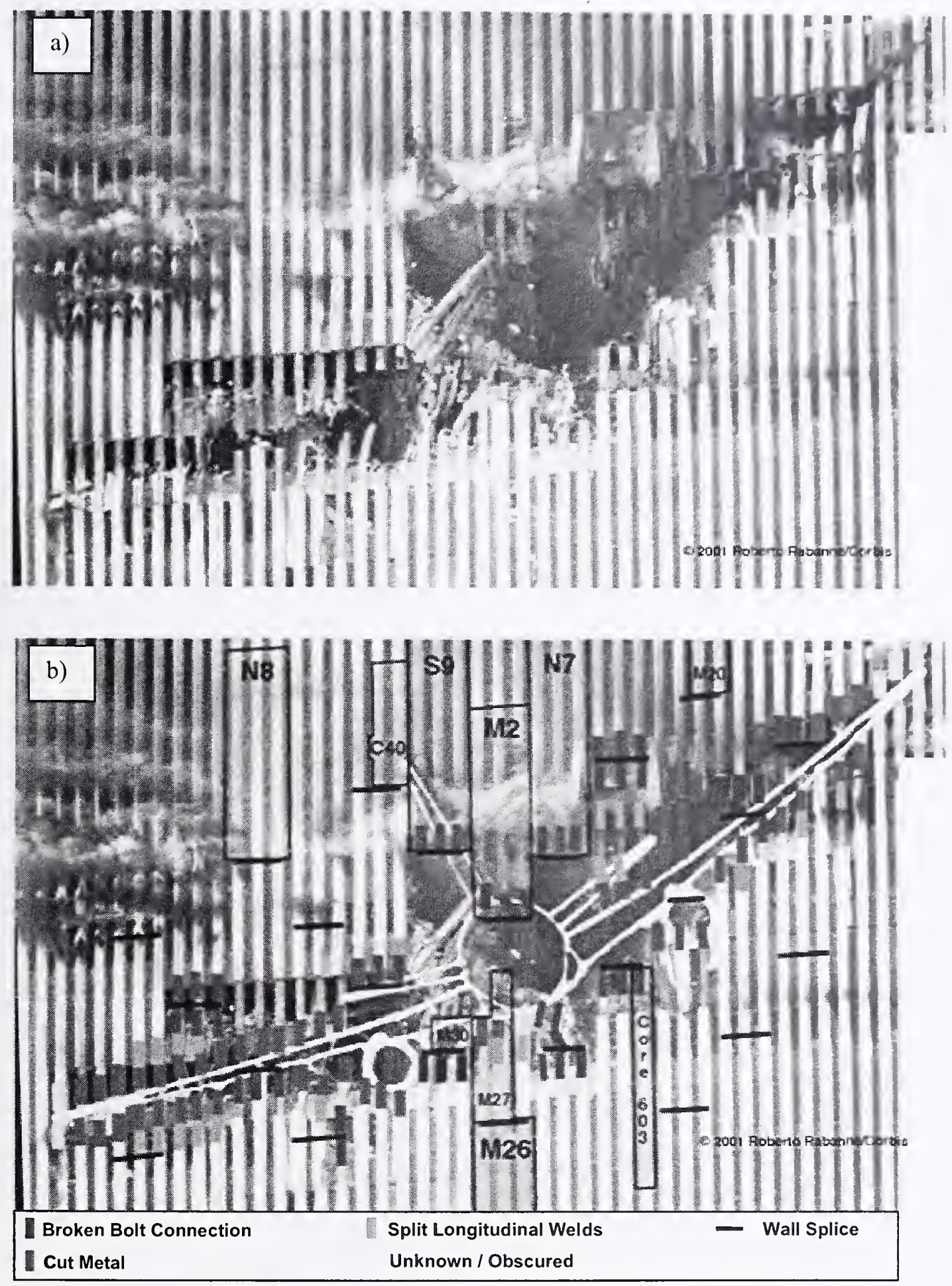

Figure 6-1. (top) Enhanced image showing the impact hole in the north face of WTC 1, and (bottom) overlay of an outline of a Boeing 767 that has been distorted to get a best approximate fit with damage to WTC 1 . The location and type of localized damage has been indicated. 


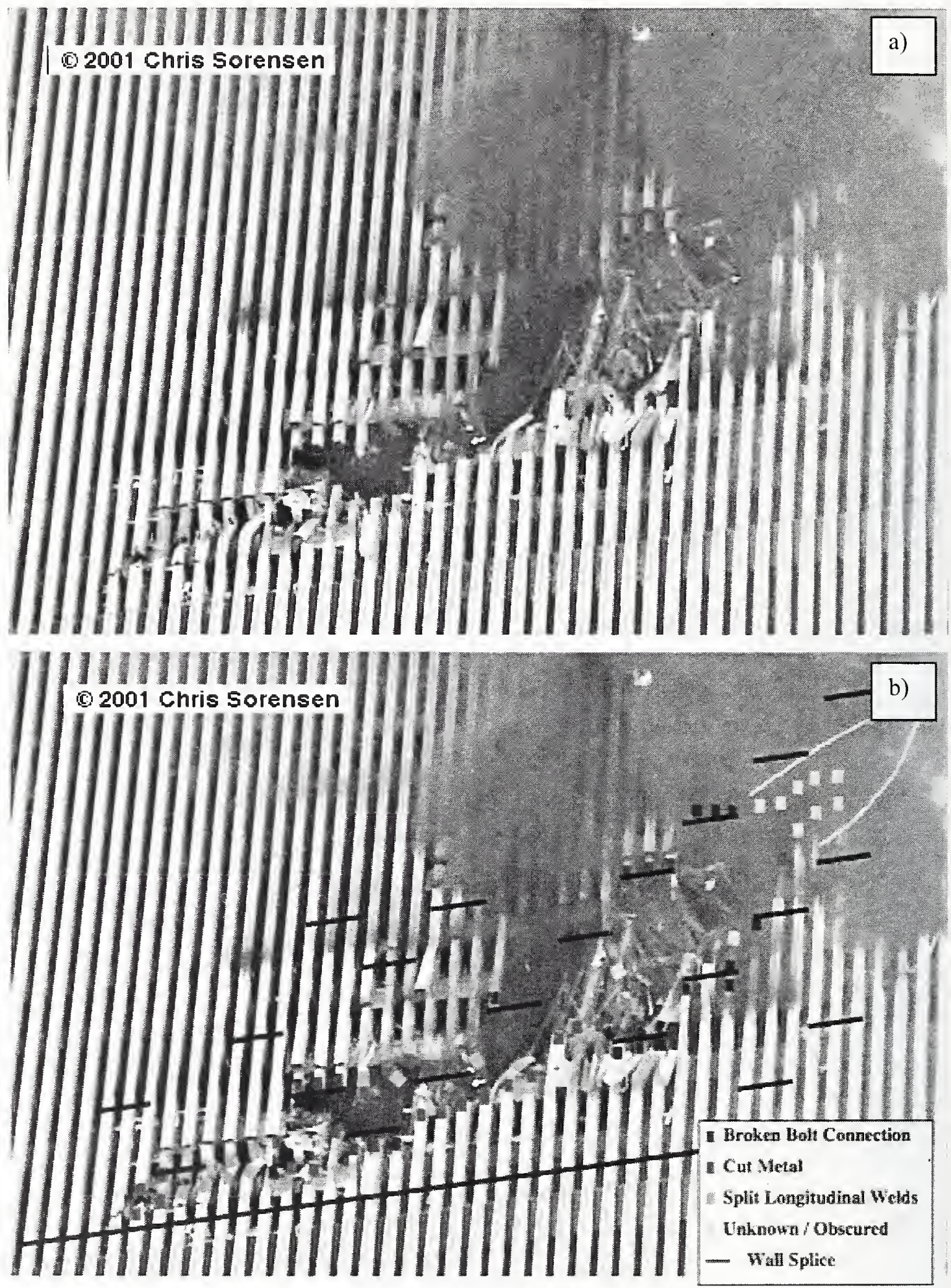

Figure 6-2. (top) Enhanced image showing the impact hole in the south face of WTC 2 and (bottom) overlay of the location and type of localized damage. 
Parts of the aireraft that impacted the south facc of WTC 2 exited the building on the north facc and landed some distanee from the building. In particular, it was believed that an cnginc cxitcd the northeast corner of the building on floor 81 , and a landing gear strut componcnt eut through the wall on the north face near the northeast corner on the same floor. Images werc examined to determinc damage causcd by these piees in order to feed this information back to the impact damage and building stability models.

Several images taken from different angles and with different smoke and lighting conditions werc examined to characterize the damage. Fig. 6-3 is a view of the northeast corner of WTC 2 centered on approximately the $82 \mathrm{nd}$ floor. The 81 st floor, where the engine exited, was pilcd full of burning dcbris. The corners of the buildings were designed such that every other floor had a column in this space, an example of which ean be seen above the hole, indicated by the arrow. The plans of the building show that the 81 st floor was one without a column, consistent with the image, so that the exiting enginc did not remove one as it exited the hole. Also, examination of this and two other images showed that the columns that border the hole to the left and right appear undamaged, so that the engine appears to have not damaged the building structurally as it exited.

On the right side of the image in Fig. 6-3 is the north face of WTC 2. It was believed that a large component of a landing gear exited the building on this face near the northeast corner in the region of the 80th floor. On Fig. 6-4, the arrows indicate where the columns have been cut (regions of missing column denoted by blue arrows) or where a bolted connection has broken and bent the column ends outward slightly (green arrows). The bolted connections were broken at the 81st floor in columns 257 and 258. The entire column was eut through at columns number 254 and 255, also at the 81 st floor. (Column 254 retained an intact outer web, however [red arrows]. The web had fractured free of the rest of the column over a distance of slightly more than two floors. Since the flange tips can be seen on either side of the outer web, the fractures occurred within the flange plates.) These exterior columns were no longer load bearing.

\subsubsection{Photographic Evidence of Damage to the Flooring System of WTC 2}

Several images, such as Fig. 6-5, showed what appear to be sagging or hanging floor slabs in the windows on the east and north faces of WTC 2. The thickness and color of the feature indicated by arrows in Fig. 6-5 are consistent with that of the concrete slab of the floor assembly (see NIST NCSTAR 1-6C). The floor slab in Fig. 6-5 appeared in the windows bounded by columns 241 and 248 on the 80th floor, and in earlier images was bounded by columns 245 and 248, indicating that the floor slabs moved over time.

The details and implications of the presence and locations of these floor slabs are discussed in greater detail in NIST NCSTAR 1-6E:

\subsubsection{Damage to Sprayed Fire Resistive Material in WTC 1}

According to construction documents (Feld 1971), the sprayed fire-resistive materials (SFRM) (i.e., fireproofing) applied to the exterior of the outer columns within the impact regions of both towers was the same material and application process used for core columns and floor trusses. One of the parameters in the impact and fire analysis was the condition of the SFRM, so available photographs were examined for evidence of its condition after impact. 

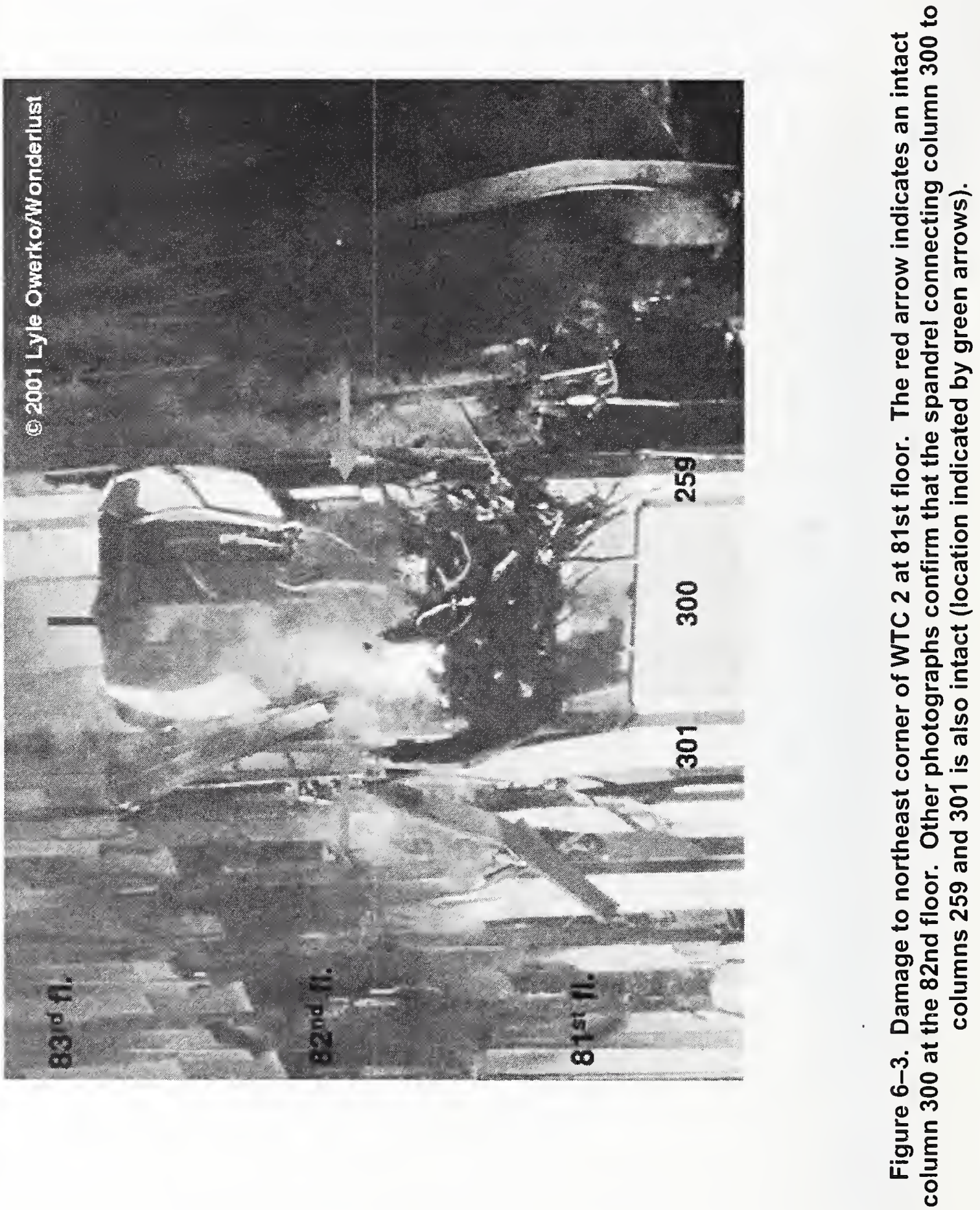


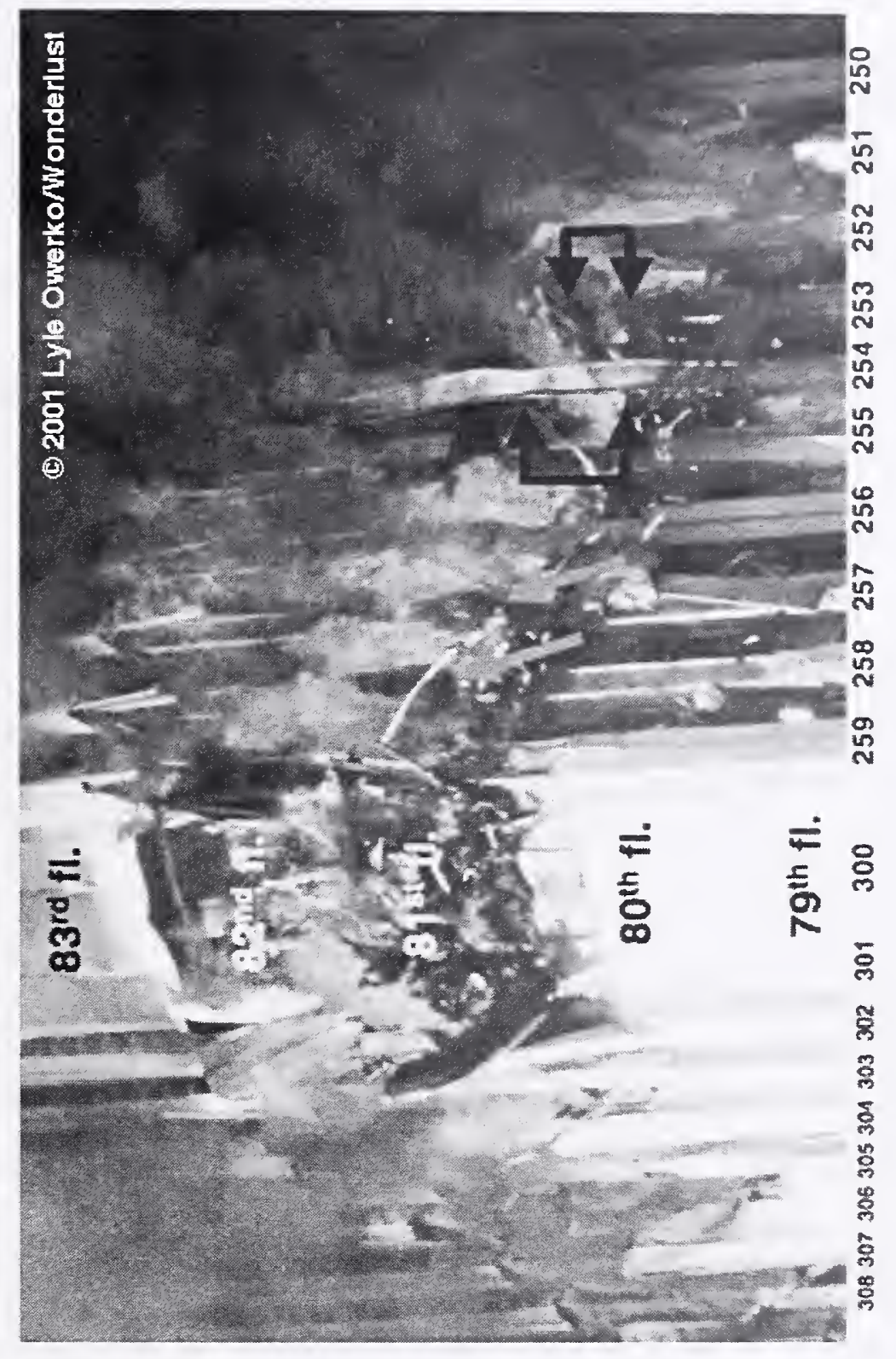

جิ

范 0

은 눈

E

สำ

는

踥

은 은

$\stackrel{0}{\frac{2}{0}} \frac{1}{0} \stackrel{0}{\frac{0}{2}}$

ฮ)

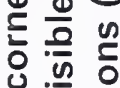

$0 \cdot \frac{n}{>}$

แ

ब

क

일

เั

$\$$ ㅇ

ㅎำ

느믐ำ

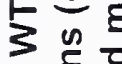

흐을

\&

约 至

든 은

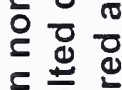

은

들 눈

ह $\frac{\mathrm{E}}{\mathrm{O}} \mathrm{E}$

$00 \frac{2}{0}$

응

๑등

ช

$\frac{E}{\sigma}$

๑ั

ரீ

는 은 응 


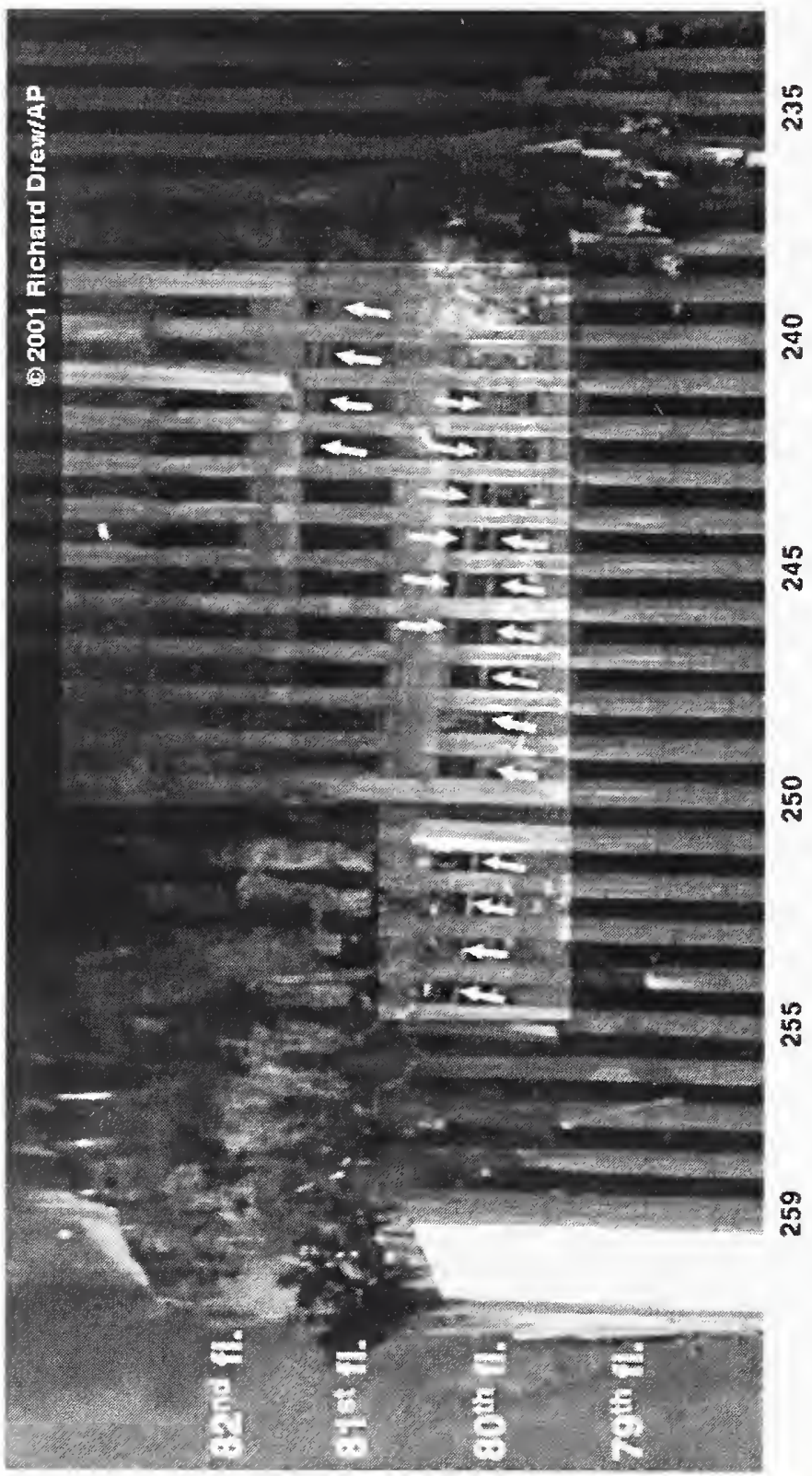

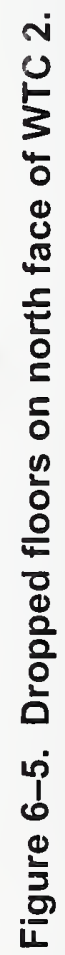


Areas of particular interest were around the impact holes in cach tower, as well as regions where the exterior walls were impacted from the inside by debris, causing the extcrior facade to be damaged. The photos were enhanced digitally to reveal the condition of the SFRM. The image processing techniques involve changing the range of displayed levels and cffective gamma, the application of filters such as unsharp mask and edge sharpcning, and subtracting filtercd images from the original to highlight specific features. For an explanation of thesc imagc processing tcchniques, the rcader is referred to Russ (1995).

Figure 6-6 schematically shows how the SFRM was to be applicd to the exterior columns, with a relatively even thickness coating to all exterior portions of the column. In practicc (Fig. 6-7), it appcars the SFRM was sprayed so as to fill the depression formed by the outer web of the column and the protrusions of the two column flanges, so that the outer face of the column appeared flat (Fig. 6-7). Figure 6-6 shows details of the architectural aluminum panel attachment to the window frames, suggesting how the blowout of windows and frames could possibly pull off the aluminum panels as well.

There was extensive photographic evidence of SFRM damage around the impact hole on the north facc of WTC 1. This was not surprising considering the energy of the impact. However, some of the damage was a considerable distance from the impact site.

Figure 6-8 shows the east side of the impact hole in the north facc of WTC 1. Arrows indicatc where the SFRM was damaged, and in several locations the underlying paint showed through. Examining these images further, it was possible to view the trusses on the undersidc of the floors that collapsed into the impact hole (Fig. 6-9). In the two instances indicated on the figure, the details of the structure and the paint color of the lower chord of the trusses were quite visible, indicating that most if not all of the SFRM had been dislodged.

\subsubsection{Damage to Sprayed Fire-Resistive Material in WTC 2}

In WTC 2, there was substantial damage to perimeter wall SFRM due to impact of debris from inside the building, as discussed below.

\section{North Face Near Northeast Corner}

The north face of WTC 2 contained the exit holes for some of the debris from the collision of the aircraft. This debris consisted of aircraft components, building contents, and possibly structural parts of the building. This debris impacted the interior of the north wall, blowing out windows, damaging exterior columns and removing aluminum exterior panels and SFRM from the columns.

A broad region of the north face of WTC 2, spanning columns 230 through 259 and the 79 th through 82nd floors, had the exterior aluminum panels and SFRM damaged or removed due to debris impact from within the building. In particular, a rectangular region consisting of columns 239 through 249 on floors 79 through 81 was found to be completely free of aluminum panels, and the bcst observations of SFRM damage were made here (Fig. 6-10). Red arrows indicate where the SFRM was dislodged from the outer web between the protruding tips of the flanges. This determination was made using this image and other higher resolution images. The appearance of white linear features on the edge of the columns, at this angle of solar illumination, shows the absence of at least some, if not most SFRM from the center region of the outer web of the column. In contrast, column 246 (green arrow) shows bright contrast 


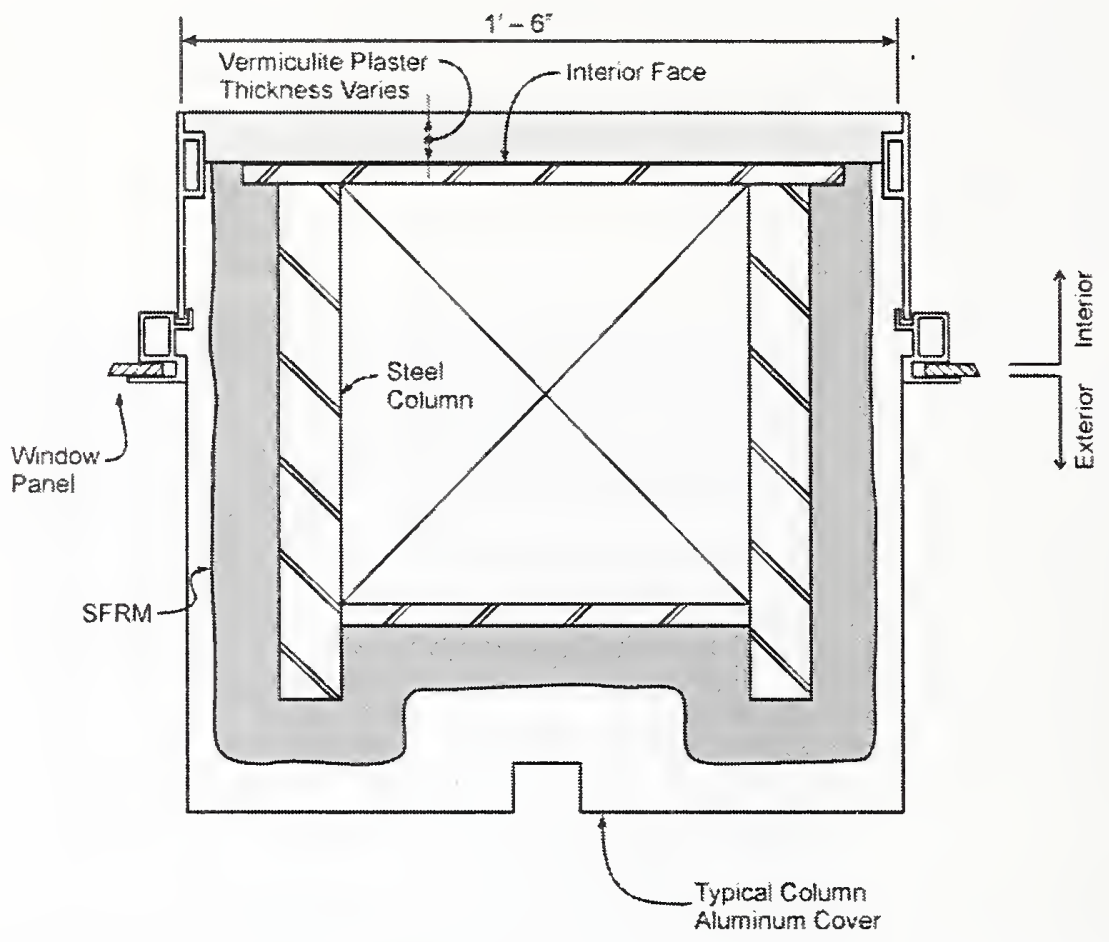

Figure 6-6. Diagrams showing how the fireproofing was to be applied to the exterior columns, and the exterior aluminum panels were attached to the window frames. 


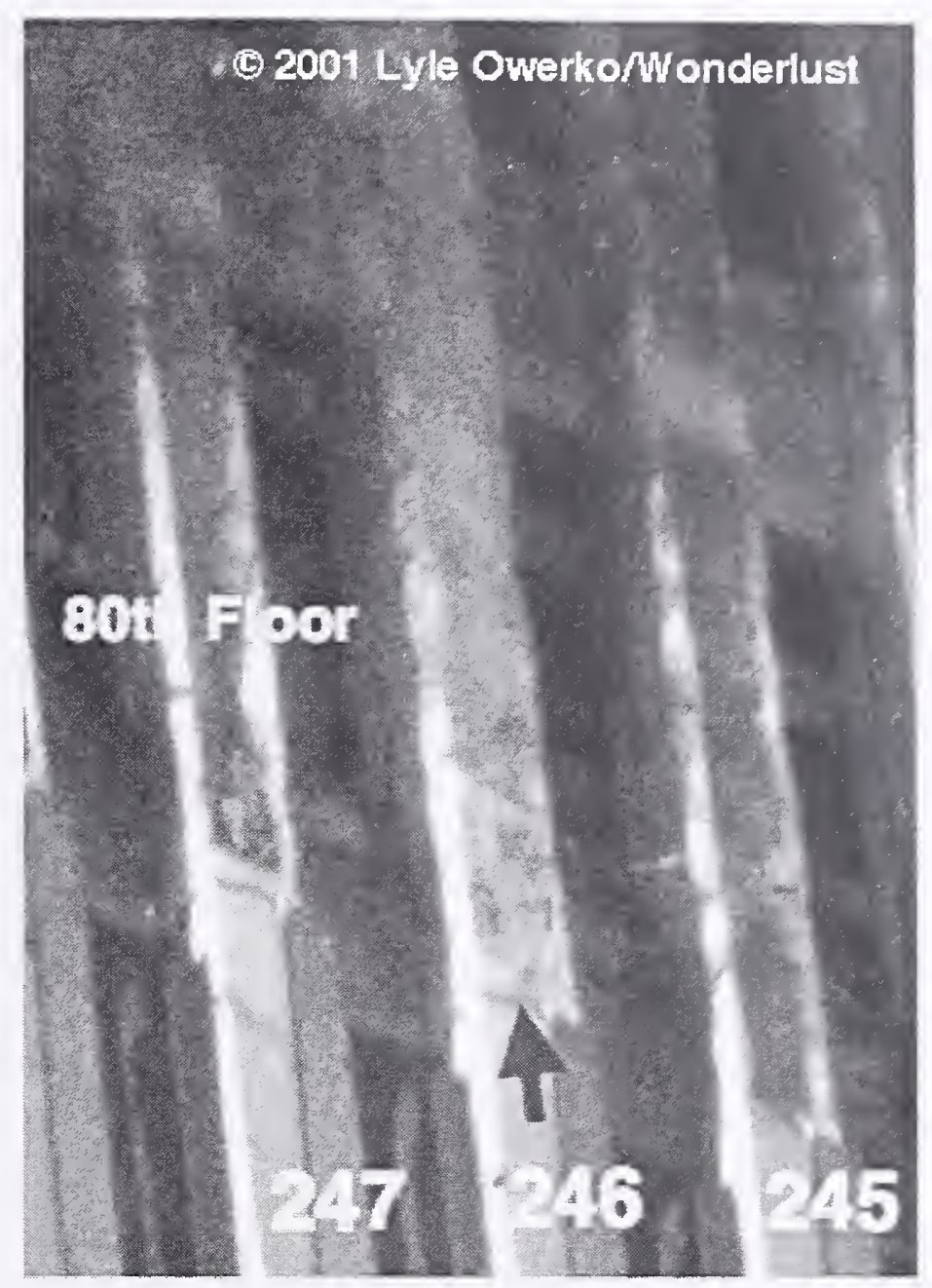

Figure 6-7. Fireproofing that had been applied to the exterior columns. The depression formed by the outer web and the flange tips are completely filled in with fireproofing at the arrow. North face of WTC 2. 

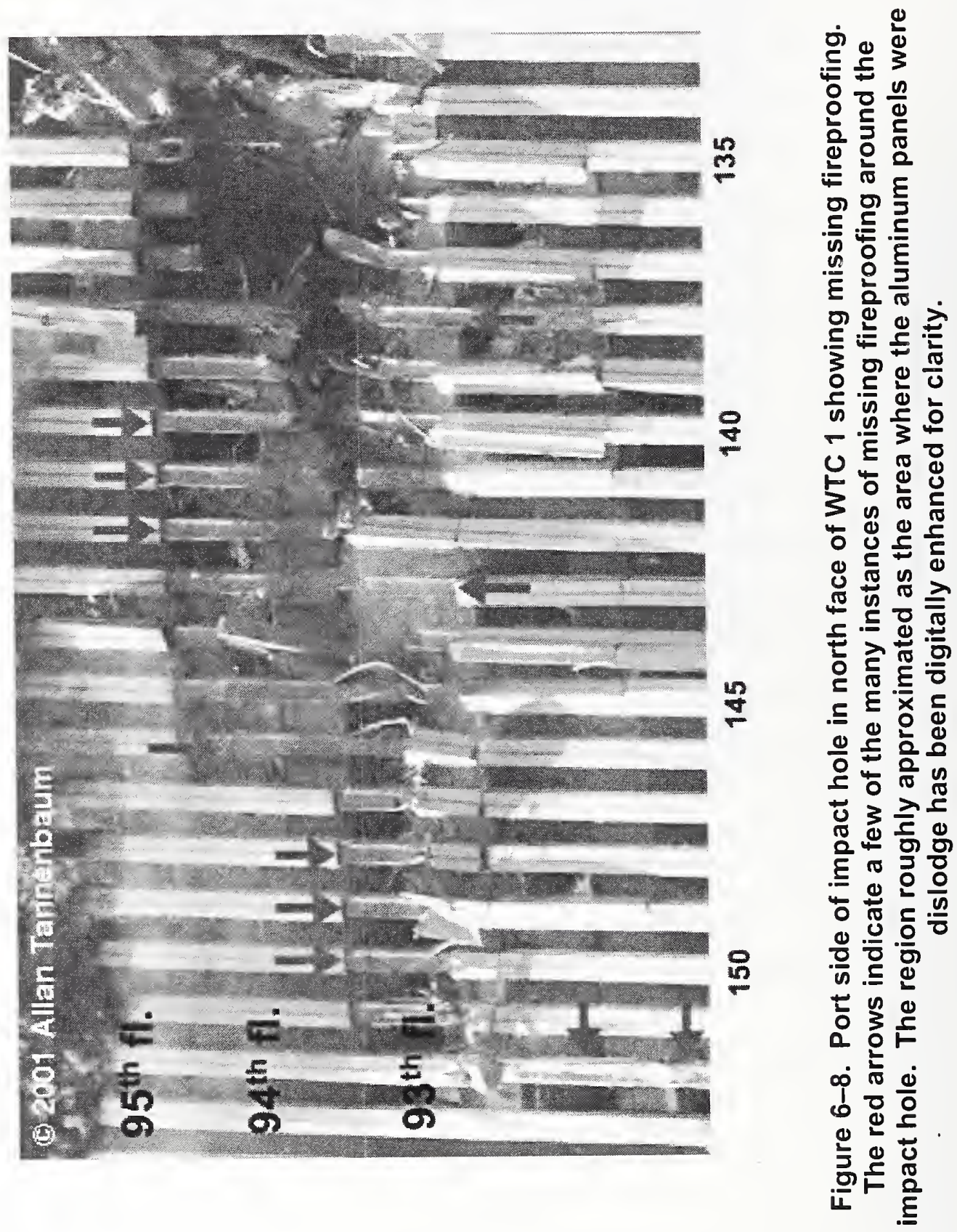

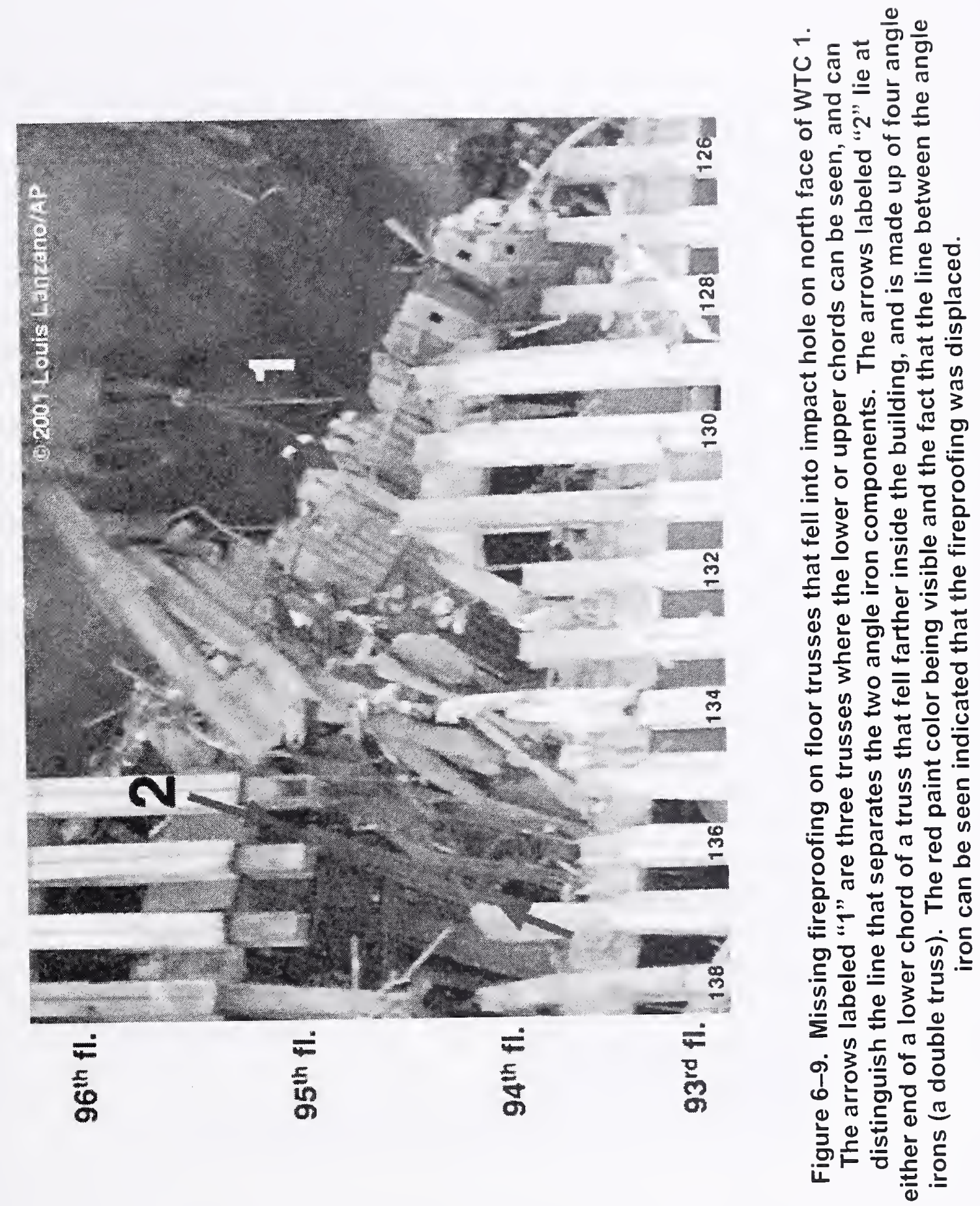

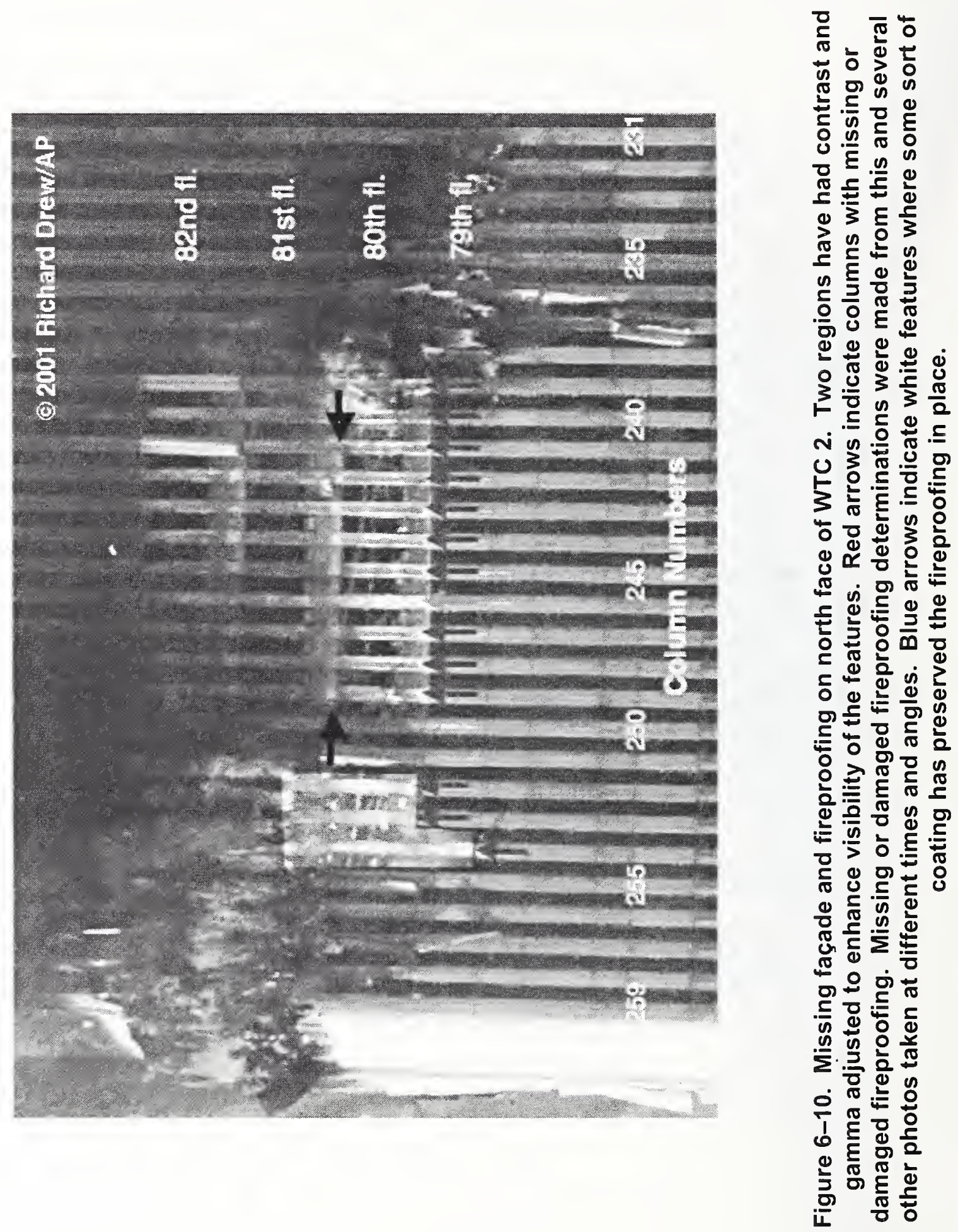
across the entire face, and this and other photos confirm that the SFRM was nearly intact along this column for the entire exposed three floors, despite the fact that the aluminum facade has been dislodged.

Additional images taken of the region at higher resolution (Fig. 6-11) showed more subtle details about the SFRM damage. The red arrows indicate where the SFRM has been dislodged completely from the flanges, as evidenced by the exposed red Tnemec paint on the columns. It was not possible to make an unambiguous determination as to whether the insulation on the exteriors of the spandrels was damaged in any of the photographs. This photo also reveals details about the loss of the SFRM. The blue arrow in Fig. 6-11 points to an example of a band of white features that appear wherever two aluminum panels met on the exterior of the building, the white feature becoming visible when the panels were dislodged. This appears to be a coating applied to protect the SFRM from moisture infiltration at the aluminum panel joints. This coating appears to have prevented the loss of SFRM in a great many locations where the SFRM was knocked off both above and below this location.

\section{East Face of WTC 2}

The interior of the east face of the tower was not impacted as directly as the north face, but nevertheless experienced damage to both aluminum exterior panels and SFRM. The damage was scattered across a large fraction of the east face on the 79th through 82nd floors (Fig. 6-12), including areas where the SFRM has been damaged or removed to the level of the paint (red arrows). Loss of SFRM was not found south of column 316 on this face of WTC 2, but since dislodged SFRM can only be seen if the aluminum panels were also dislodged, and the panels south of column 316 were intact, this does not mean that the insulation was necessarily undamaged.

\subsubsection{Photographic Analysis of Pre-Collapse Fire Exposure to Exterior Panels}

The NIST Investigation Team used photographic images, video images, and other relevant information to develop detailed time lines for the spread and growth of fires in the towers (NIST NCSTAR 1-5A). This data was utilized to ascertain the location and extent of fire exposure for the recovered exterior panels. The methodology used to develop the information below is described in (NIST NCSTAR 1-3C).

In WTC 1, the 89th through 110 th floors were analyzed for fire exposure. From the 26 recovered panels identified from WTC 1, 22 panels fall within this range. In general, fire was observed on floors 92 through 99 as well as the 104th floor. Sixteen of the 22 panels were exposed to fire during the $1 \mathrm{~h}$ and 42 min that WTC 1 stood after the impact. For WTC 2, the 77th through the 110th floors were analyzed for visual observations of fire. Nine of the 15 panels recovered from WTC 2 were from this region. In general, fire was observed from floors 78 through 83. No visual evidence of fire was observed near any of the recovered panels prior to the collapse of WTC 2.

Figure 6-13 displays a time-fire exposure map for panel K-2 (WTC 1, center column line 236, floors 92 to 95). On the right-hand side is a schematic showing the recovered portion of the panel, drawn as if viewed from outside of the building, with the floors and column lines labeled. The "grayed-out" sections of the panel were not recovered, resulting in portions of only six different windows available for inspection. On the left-hand side of the figure, the time line analysis for exposure to fire can be observed for that given panel, along with the color-coded, numerical key. The location of each window for a given 

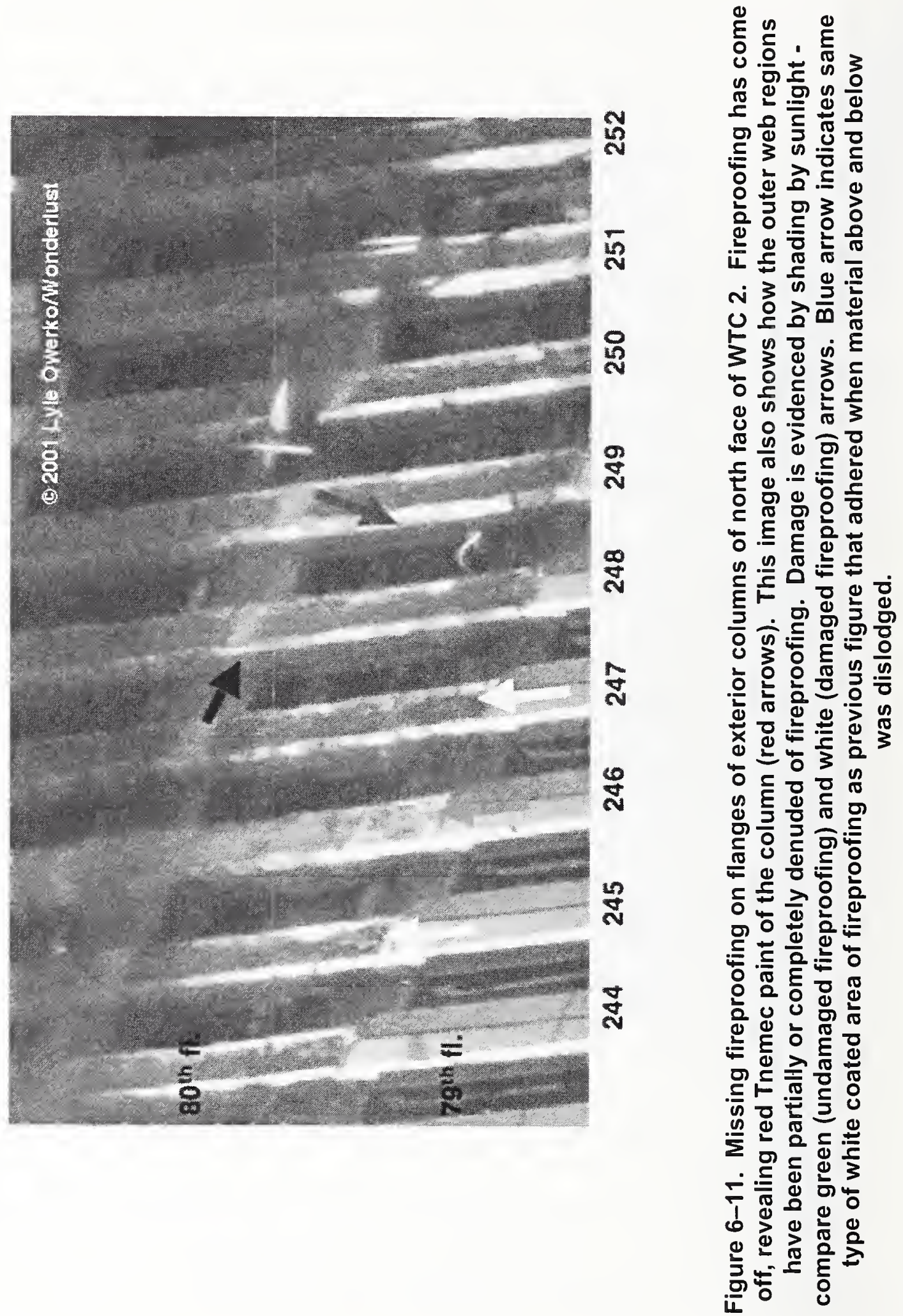


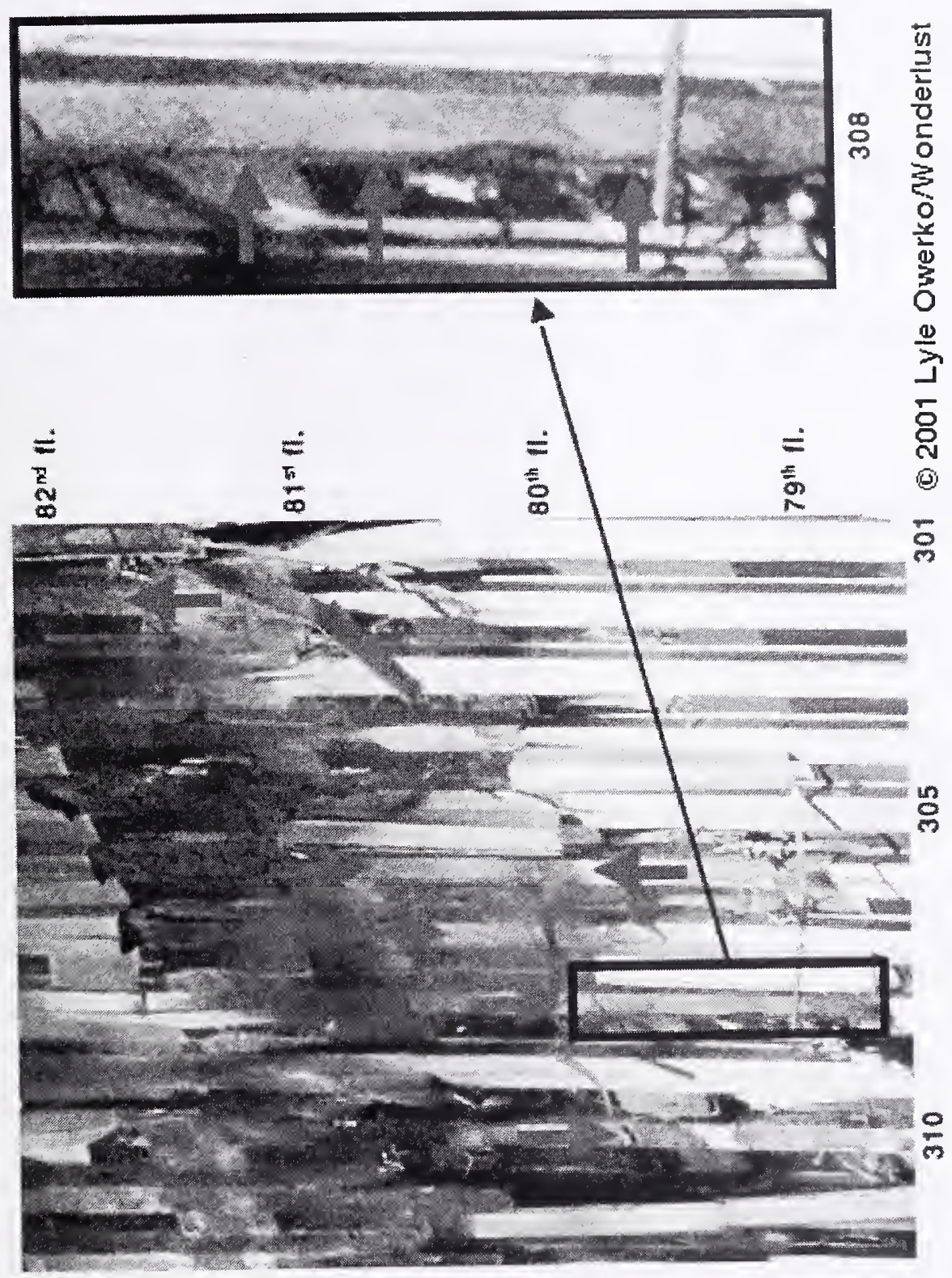

我 $\frac{5}{3}$

\%

¿ $\sum_{3}^{n}$

눈 음

点苛

$\bar{\pi}$

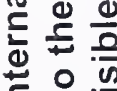

.$\pm \frac{10}{>}$

울을 느

ํํㅇ 응

N

$0=0$

$\sum$ -

宁 峞。

ब

苋岳

in 0

농

ᄃ ฏ

ำ

oा

든 응

잉 인

은 응

는 인

证

온 는 $\frac{5}{3}$

崩

完

旋 $\frac{2}{3}$

0 in

ํํํํำ

है

$0 \pm$

을 을

흔 $\frac{\bar{g}}{2}$ 


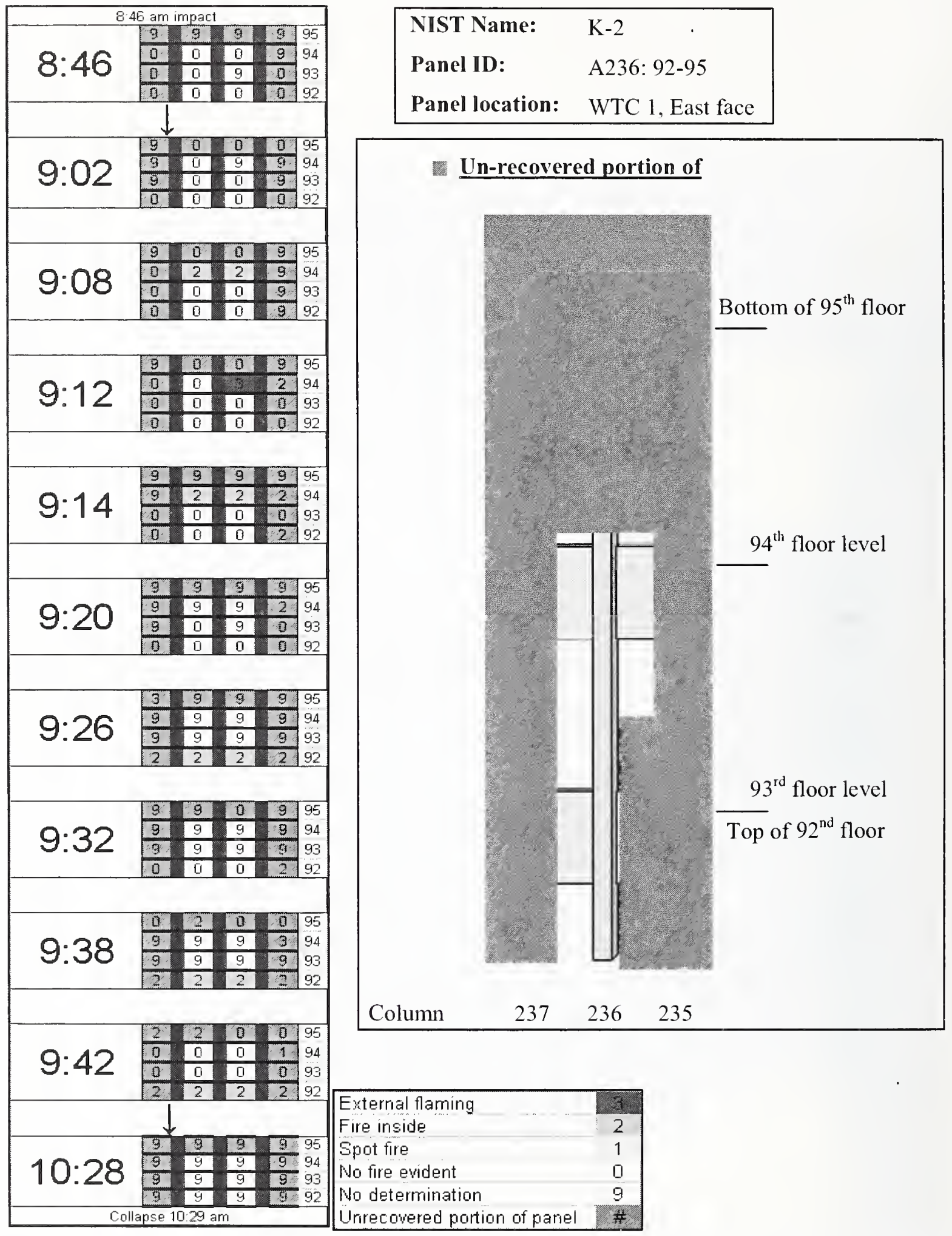

Figure 6-13. Time-fire exposure map for panel K-2 (A236: 92-95). Fire can be observed on the $92 \mathrm{nd}$ and 94 th floors of the panel. 
time is consistent with the recovercd panel diagram. Similar to the "graying-out" of the pancl schematic, the corresponding windows wcre "grayed-out" in the time scquence, however, the numcric key is still visible. In the analysis, the windows were numbercd for a given floor (similar to the original column lines of the perimeter panels) and the determination was made from the resources (photographic and video images) as to which catcgory each individual window fell into for the given time framc. The categories were labeled as:

0 : No firc was visible

1: Spot fire or small isolated fire

2: Fire visible insidc

3: External flaming

9: Unable to be determined (typically as a result of smoke obscuring the window).

For the recovered portion of panel K-2, fires were observed on the 92nd and 94th floors around column 236. This information was correlated with the visual cvidence for fire exposure on the recovered panels as well as the paint mapping study discussed in Sec. 1.6.

Table 6-1 lists the panels recovered from the floors involved in fire and a description of the extent of direct fire exposure based on the pre-collapse images.

\subsubsection{Photographic Evidence of Pre-Collapse Distortion of Exterior Wall: South Face of WTC 1}

As a result of the fires and load redistribution, exterior walls in each tower bowed inward well before the initiation of global collapse. Approximately 6 min before collapse, a New York City Police Department (NYPD) helicopter image captured such bowing in the south face of WTC 1. The image is shown in nearly its entirety in Fig. 6-14, and the analysis is shown in Fig. 6-15.

The magnitude of the bowing on the south face was calibrated using column spacing on the west wall as follows. A true vertical column line in the bowcd region was established by extending the column lines along 20 floors below the damaged region. This was extended along the same line through the smoke filled regions. The distance the columns were deformed into the building perpendicular to the south face was established by measuring angles and distances on the west face at the southwest corner of the building (see Fig. 6-15, lower left). This established the angle (167 degrees from right horizontal) and base magnitude ( $120 \mathrm{ft}$ pcr 88 pixels) of the inward bowing vector. The foreshortening of the south face due to perspective was calculated and applied to the distances measured on the south face, and increased the measurements by a maximum of approximately 15 percent over the physical distance measured on the image.

The region over which the exterior columns appear to bow inward spans nearly the entire face, and extends vertically over at least four floors, if we assume continuity between the inwardly bowed sections on the east and west sides of the south face. The maximum inward bowing at this time is $55 \mathrm{in}$. $+/-6$ in. near column 316 on the 97 th floor. Note that this is the maximum that is visible, but a large portion of the south face is obscured by smoke. An earlier image taken at 9:44 a.m., or 58 min after aircraft impact, shows that the columns were straight, indicating that the inward bowing developed quite some time after impact. 


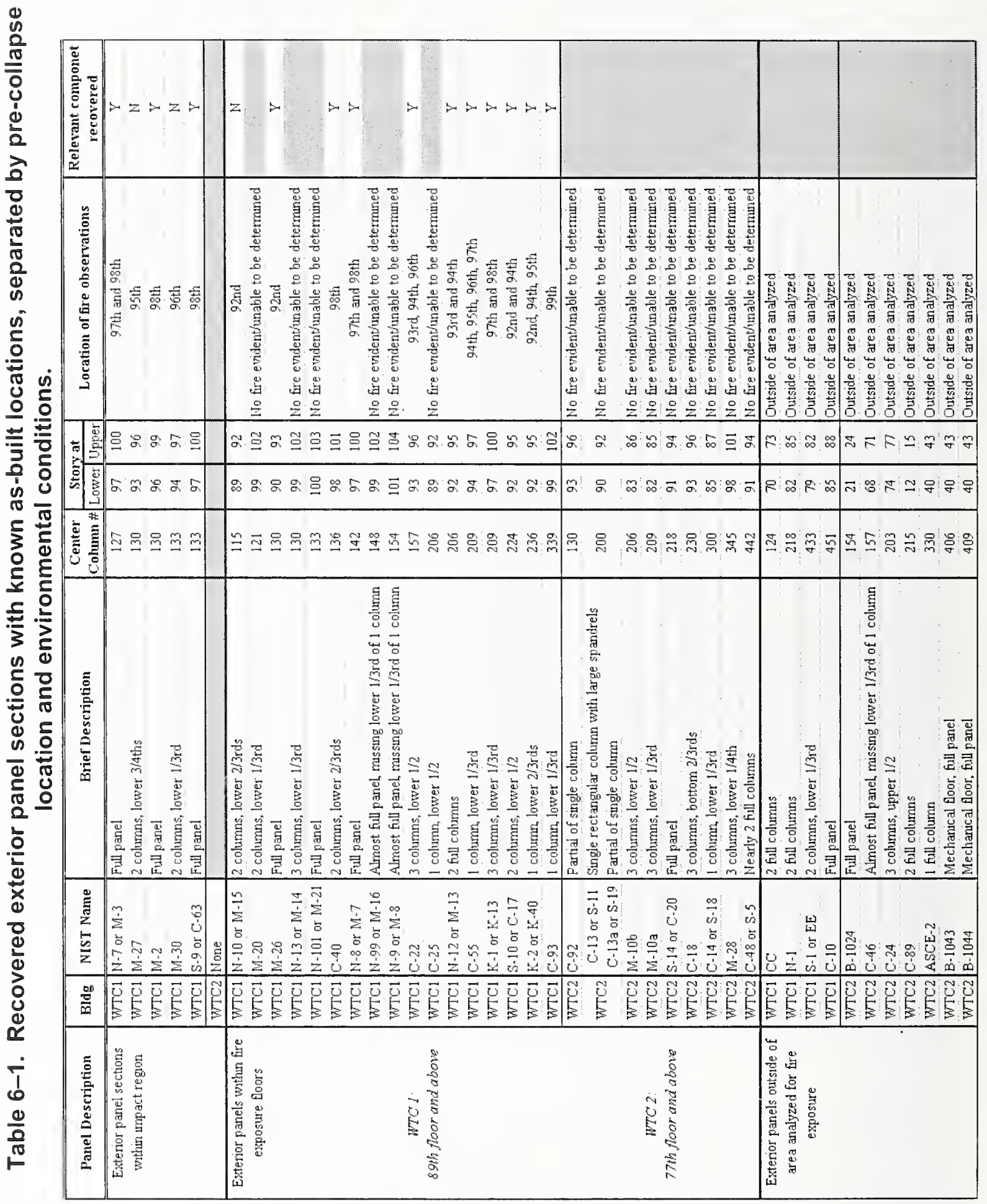




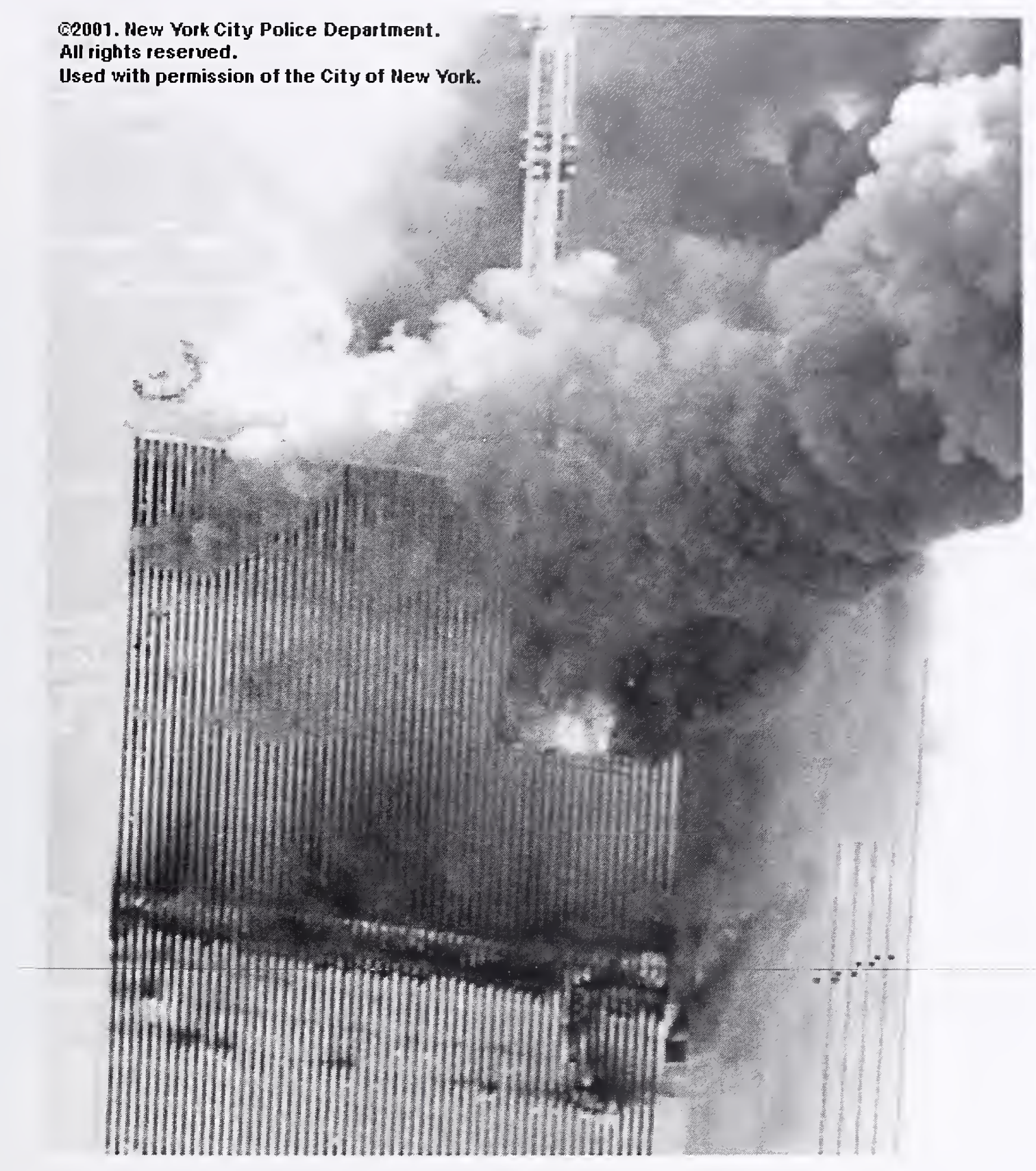

Figure 6-14. Inward bowing of south face (at right, with dark lines overdrawn) of WTC 1. Taken at 10:23 a.m. from an NYPD helicopter. 


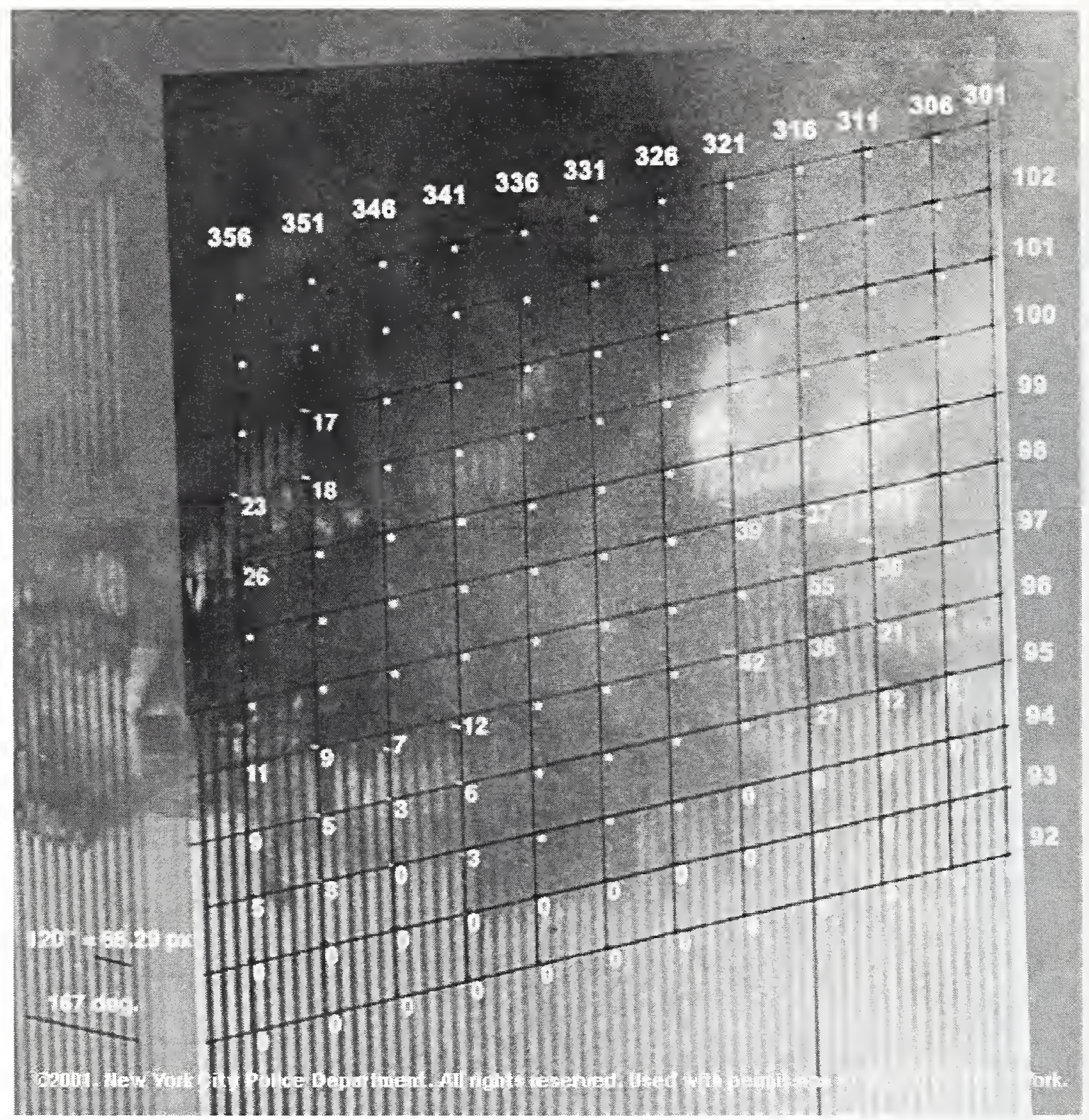

Figure 6-15. Pull in of south face of WTC 1 at 10:23 a.m. showing considerable displacements of outer columns into the building. Faint white vertical features are the aluminum façade of the exterior. Maximum visible inward displacement of the columns is 55 in. + +/ 6 in. Poor resolution leads to large uncertainties in measurements; a large fraction of the south face of the building is obscured by smoke. 


\subsubsection{Photographic Evidence of Pre-Collapse Distortion of Exterior Walls: East Face of WTC 2}

Several high-resolution photographs taken of the east face of WTC 2 in the region of the 80th floor show inward bowing of the exterior columns. Three photographs wcre of sufficicntly high resolution to cnablc measurement of the inward bowing over the surface of the face of the building.

As for the north tower images, vertical lines to establish original alignment of the columns werc drawn by tracing from unbowed sections well above and below the bowed scetion. However, for the south tower images, because of the high resolution of the images and the more normal viewing angle, the calibration for extent of bowing was based on the $11 \mathrm{in.} \mathrm{depth} \mathrm{of} \mathrm{the} \mathrm{aluminum} \mathrm{façade} \mathrm{(NIST} \mathrm{NCSTAR} \mathrm{1-3C} \mathrm{for}$ details). Corrections were made for barrel distortion of the camera lens. The estimated crror in each measurement was approximately 1 in. to 2 in.

One image was taken at 9:21:29 a.m., or 18.5 min after impact, and the other two images were taken by the same photographer at nearly the same location $10 \mathrm{~s}$ apart beginning at 9:52:54 a.m., or roughly 6 min before collapse of WTC 2 (Fig. 6-16 shows one of these images). The images were analyzed extensivcly to spatially map the inward bowing of the exterior columns across the face of the building to provide insight into when this bowing occurred and how it changed with time. (Additional figures with much lower resolution were examined to determine the amount of deflection as close to the moment of collapse as possible. These did not produce any usable results, however, due to the low resolution and obscurations.)

The resulting data are plotted in Figs. 6-17 and 6-18. (The results from the two images that went into Fig. 6-18 were combined because they were taken from the same location with the same camera only $10 \mathrm{~s}$ apart, and it was assumed that the inward bowing of the columns did not change appreciably in that time). It was clear that only $18.5 \mathrm{~min}$ after the impact of the plane, there was significant inward bowing of the east face of the building. After an additional $31.5 \mathrm{~min}$, the deflections nearly doubled in most locations.

\subsubsection{Photographic Evidence of Details of the Collapse of WTC 2}

Some details of the early stages of collapse of WTC 2 were found in the photographic record and analyzed for validation of the models of collapse. The image in Fig. 6-19 was taken about one second after the tower began to collapse, and shows the east face of the building. A noticeable kink was visible along the southeast corner of the building in the region of the 106th floor (arrow).

A more detailed analysis of the geometry has been made of this distortion, shown in Fig. 6-20. The kink was in fact a double-kink, and the directions of the axes of bending are shown in the figure. It was believed that this distortion was formed by the sideways shift of loads transmitted via the hat truss and rigid, beam-framed floors of floors 107 to 110 , and a more detailed structural analysis can be found in NIST NCSTAR 1-6E. Examination of the right side of the image, after considerable image processing. shows that the NE corner of the building bent, but had no sharp discontinuity. Thus, the sharp kink had not propagated across the face of the building. An image taken approximately $2 \mathrm{~s}$ before collapse (Fig. 6-21) shows no bending, so it is believed that the kink developed at either the moment of collapse initiation or during the earliest moments of the collapse process. 


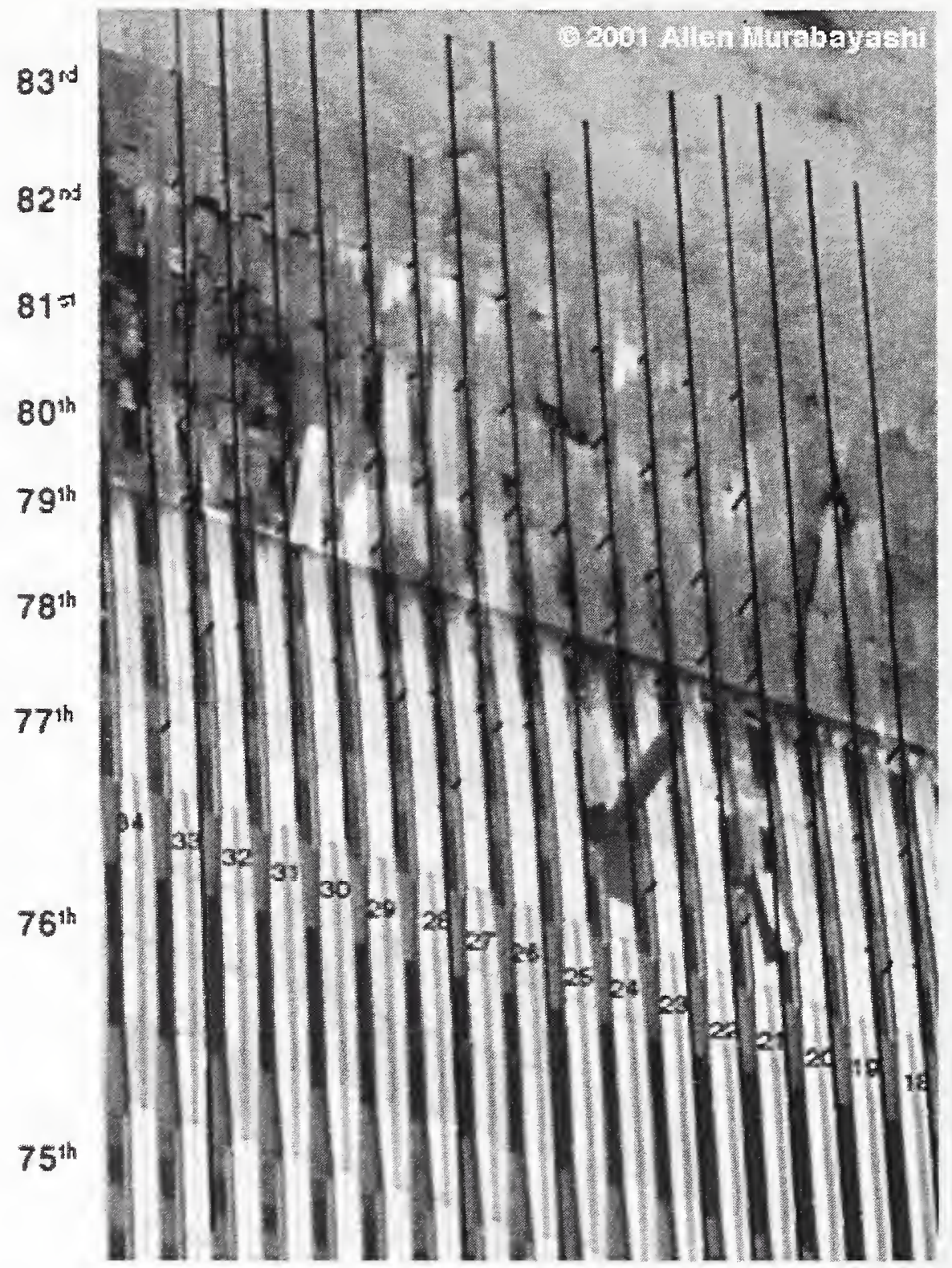

Figure 6-16. East face of WTC 2 at 9:53:04 a.m. showing a larger amount of pull in. The vertical black lines were drawn to establish the original line of the exterior wall columns, and the shorter line segments are drawn at the same angle as the nearest observable joint in the exterior aluminum panels to establish the inward bowing distance. For actual column numbers, add a " 3 " to the front of the two-digit designations in the image. 


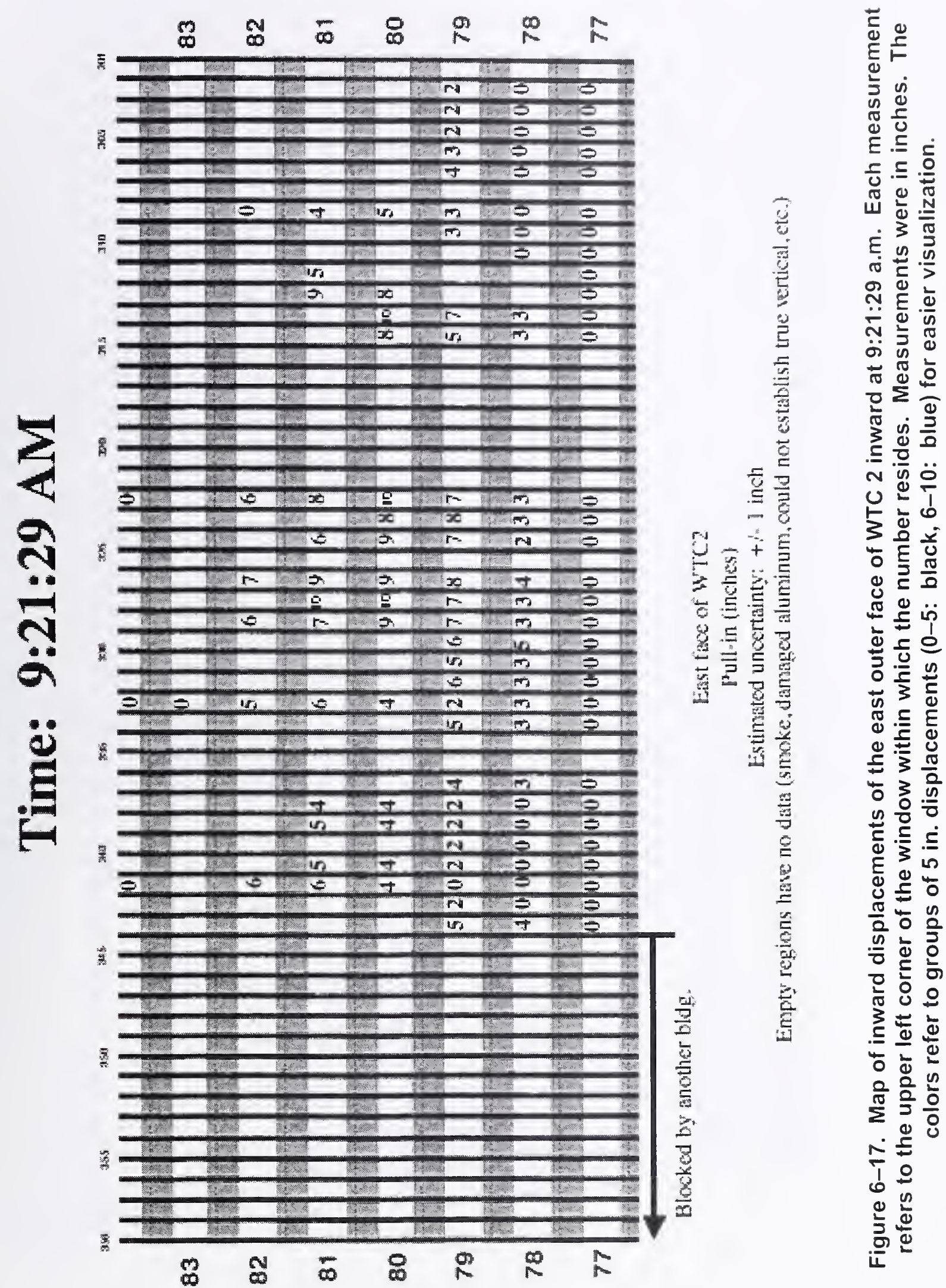




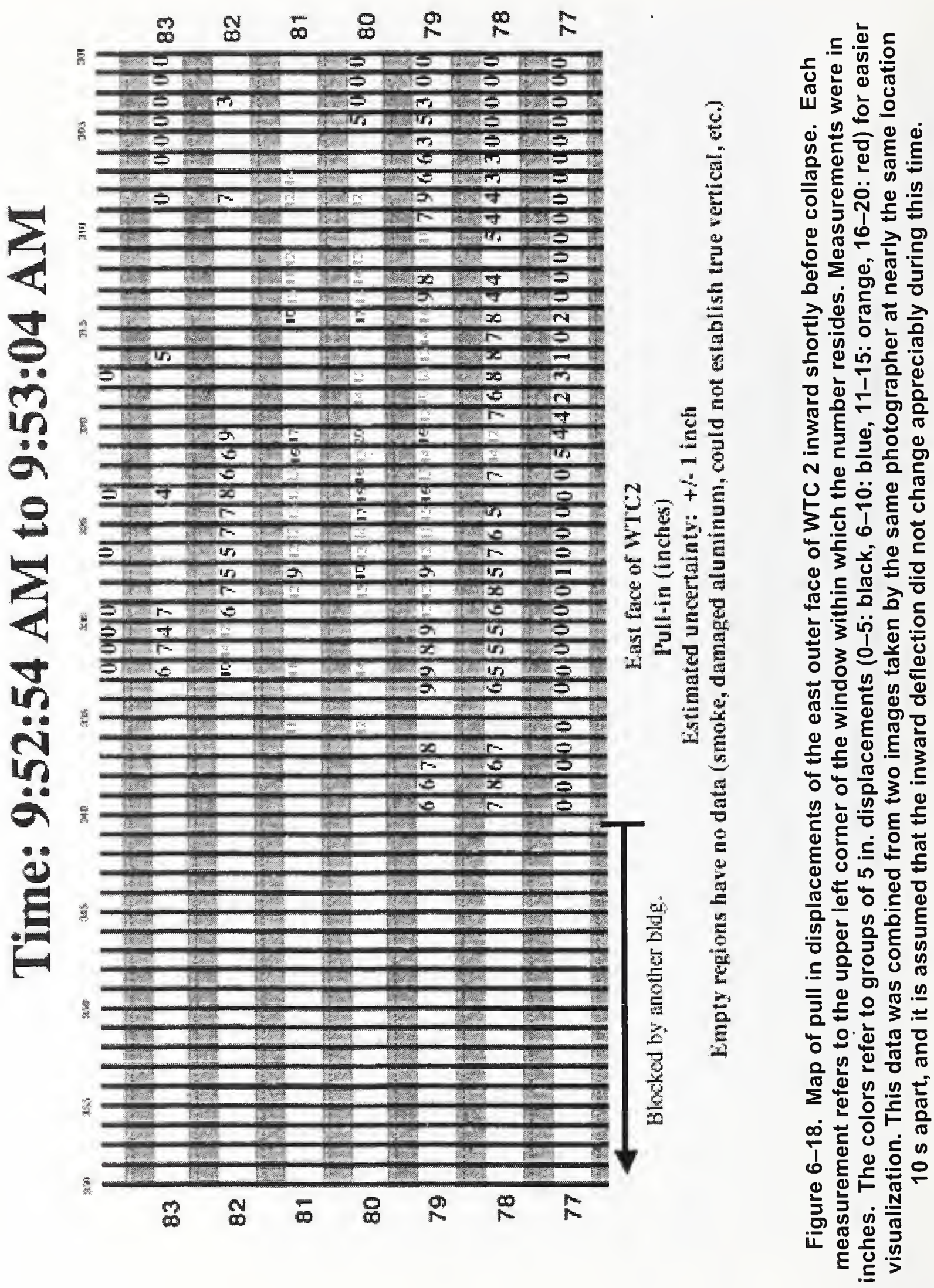




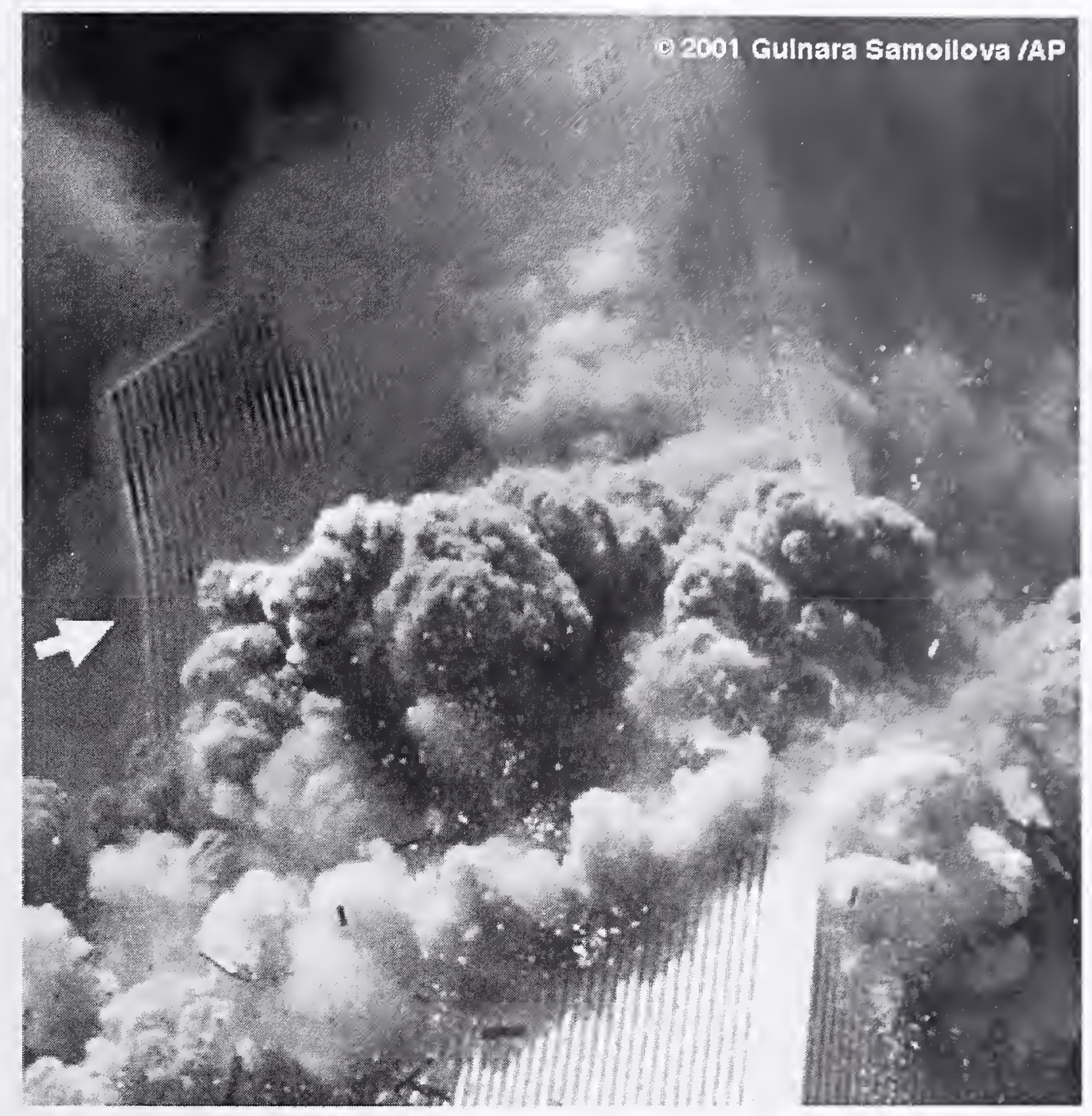

Figure 6-19. Initial seconds of collapse of WTC 2 viewed from the east-northeast, and kink in the southeast edge of the building near the 106th floor (arrow). 


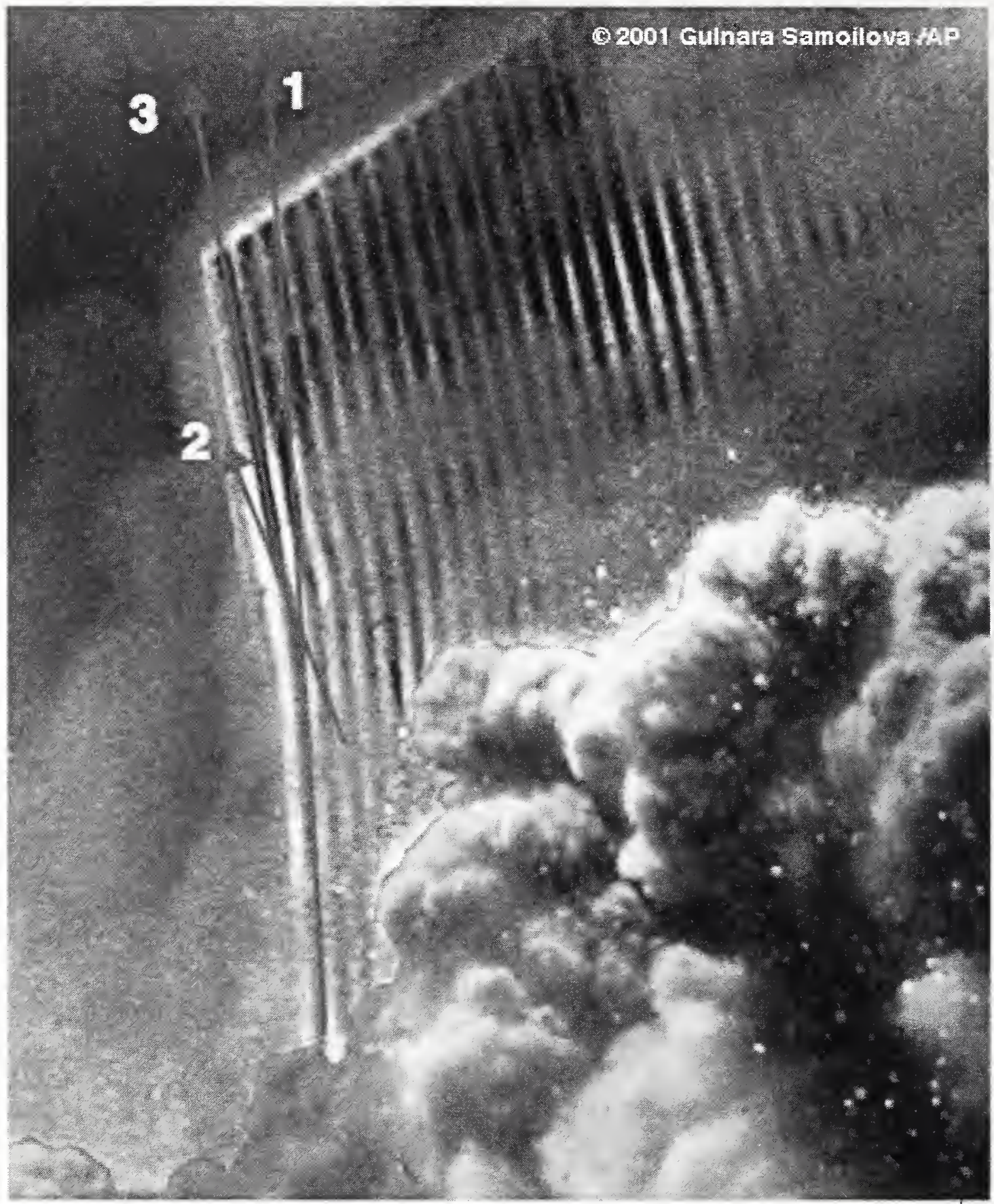

Figure 6-20. A close-up of the kink area in the previous figure (southeast corner, WTC 2), with overlaid lines to highlight the details of the kink geometry. The edge of the building (1) bends an angle to another direction (2), then bends back somewhat toward the original direction (3). 


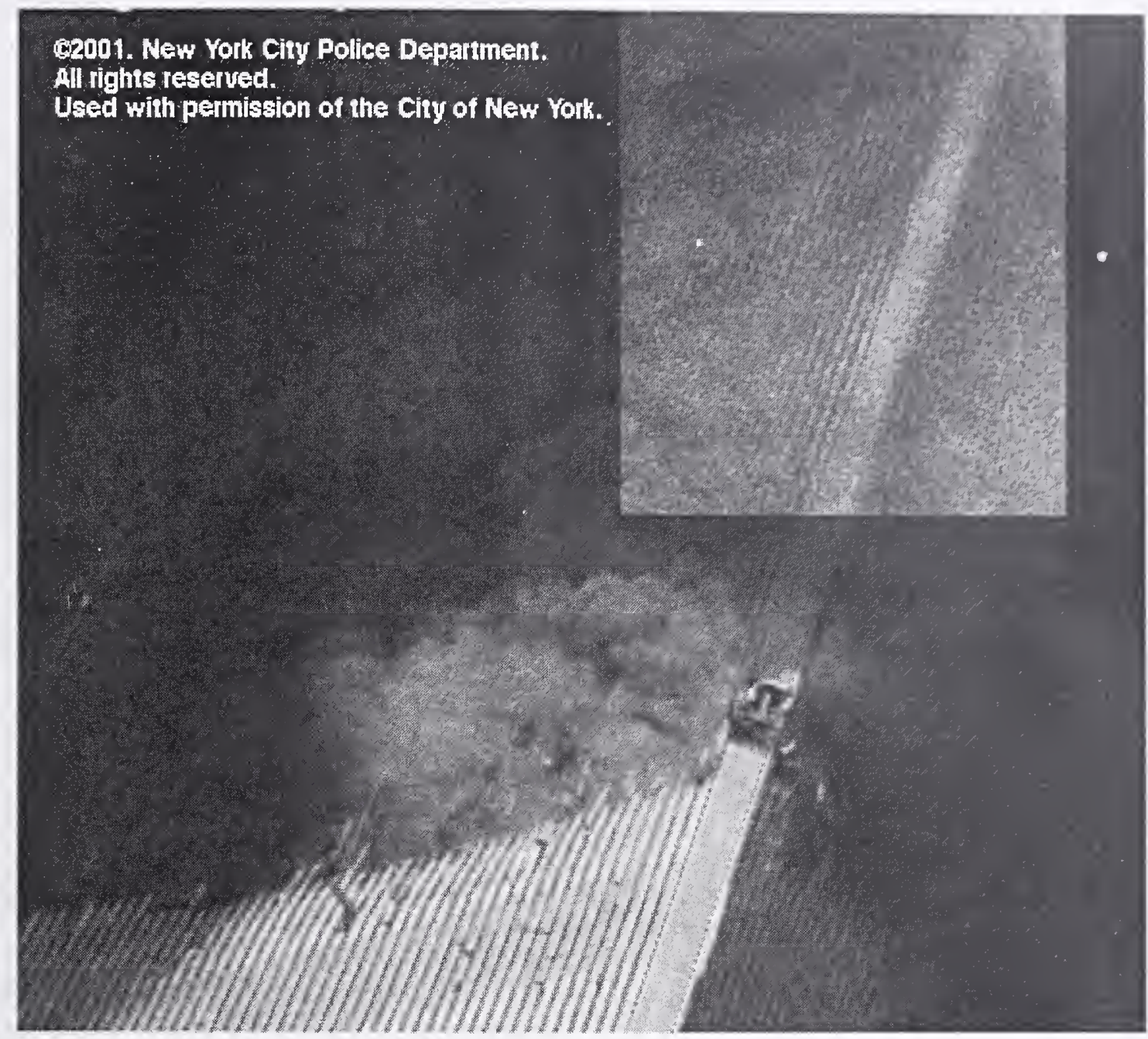

Figure 6-21. Northeast corner of WTC 2, several seconds before collapse. The corner shows no distortion of the type in the previous figure, implying that the distortion accompanied the collapse and did not precede it. The region in the upper right is enhanced for visibility.

\subsection{PHYSICAL DAMAGE OF RECOVERED EXTERIOR WALL PANELS}

Damage surveys were conducted of the recovered exterior wall panels to identify and inventory the various failure modes associated with impact and collapse of the building. The individual columns, spandrel plates, weld connections, panel splice connections (column end plate and spandrel splices), and floor truss connections were examined. In this overview, the damage to one WTC 1 panel which was hit by the airplane fuselage is shown as an example, followed by a summary of findings for all panels. As only five of the recovered panels were directly hit or otherwise sustained damage as a result of the impact, damage to the other recovered exterior panel sections was a result of events that occurred during or after the collapse of the buildings. 


\subsubsection{Overall Damage Patterns of Exterior Wall Panel Sections}

Panel M-2 (WTC 1, column line 130, floors 96 to 99) was struck by the upper part of the airplane's fuselage and the vertical stabilizer of its tail. In the photographic images (Fig. 6-1 [top]), the condition of the panel appeared remarkably similar to its as-recovered condition, Fig. 6-22a. The damage observed on the recovered panel was largely a result of the impact. The lower part of all three columns was bent into the building with the 97 th floor concrete slab acting as a fulcrum point, Fig. 6-22b. Also, the lower end plates of columns 129 and 130 were ripped off with column plate fracture occurring near welds with to the butt plates, Fig 6-22c. This gave the columns a "splayed" appearance. The end plate for column 131 was still intact, and the lower portion of the column was relatively undeformed. In the pre-collapse images, the lower portion of this column is also bent inward just below the 97th floor spandrel; however, it was bent back out sometime during or after the collapse.

Comparison of the four recovered panels that were directly impacted with pre-collapse photographs showed that two panels (M-2 and M-30) remained in a condition similar to just after impact. Some of the extraneous damage can be attributed to the events during and after the collapse, but the general shape and appearance of the recovered pieccs agree with the damage observed in the photographs. Due to the lack of detailed pre-collapse visual evidence of impact damage sustained by panels M-27 and S-9, the same assertion could not be made. Finally, the lower portion of N-7 incurred some damage; however, it could not be positively correlated with pre-collapse images.

\subsubsection{Damage and Failure Modes of Exterior Wall Columns}

Damage to the lower portion of panel M-2 (WTC 1, column line 130, floors 96 to 99) was clearly associated with impact, which led to the missing endplates for columns 129 and 130. The inner and outer web plates of both columns have thinned in this area due to plastic deformation, Fig. 6-23a. The fracturing of the plates propagated as a 45 degree slant crack, oscillating between positive and negative 45 degrees with respect to the normal of the plate. The necking (thinning) of the outer web plate, plotted in Fig. 6-23b, indicates significant ductility, even at the high-strain rates associated with impact. Large buckles were observed on both flanges for columns 129 and 130 with some splitting occurring in the base material of the flanges (Figs. 6-24a and 6-24b) and spandrels (Fig. 6-24c). However, the welds found near this bending point remained intact (Fig. 6-24d).

The five panels located in the airplane impact zone had greater damage than those outside of this region. There did not appear to be any difference in failure modes or damage characteristics whether the panels were exposed to fire or not, with the exception of the buckling phenomenon observed for the inner web plates. For the fractures that occurred near fillet welds, metallographic evaluation showed that the primary mode of fracture was initiation of a crack in the heat affected zone (HAZ) followed by propagation that was restricted to the HAZ of the base plates. Based on visual observations of all the recovered exterior panel columns, this was the dominant mode of fracture that occurred near the welds. In one case, the fracture initiated in the HAZ and subsequently propagated into the unaffected base material, although this was a rare occurrence. 

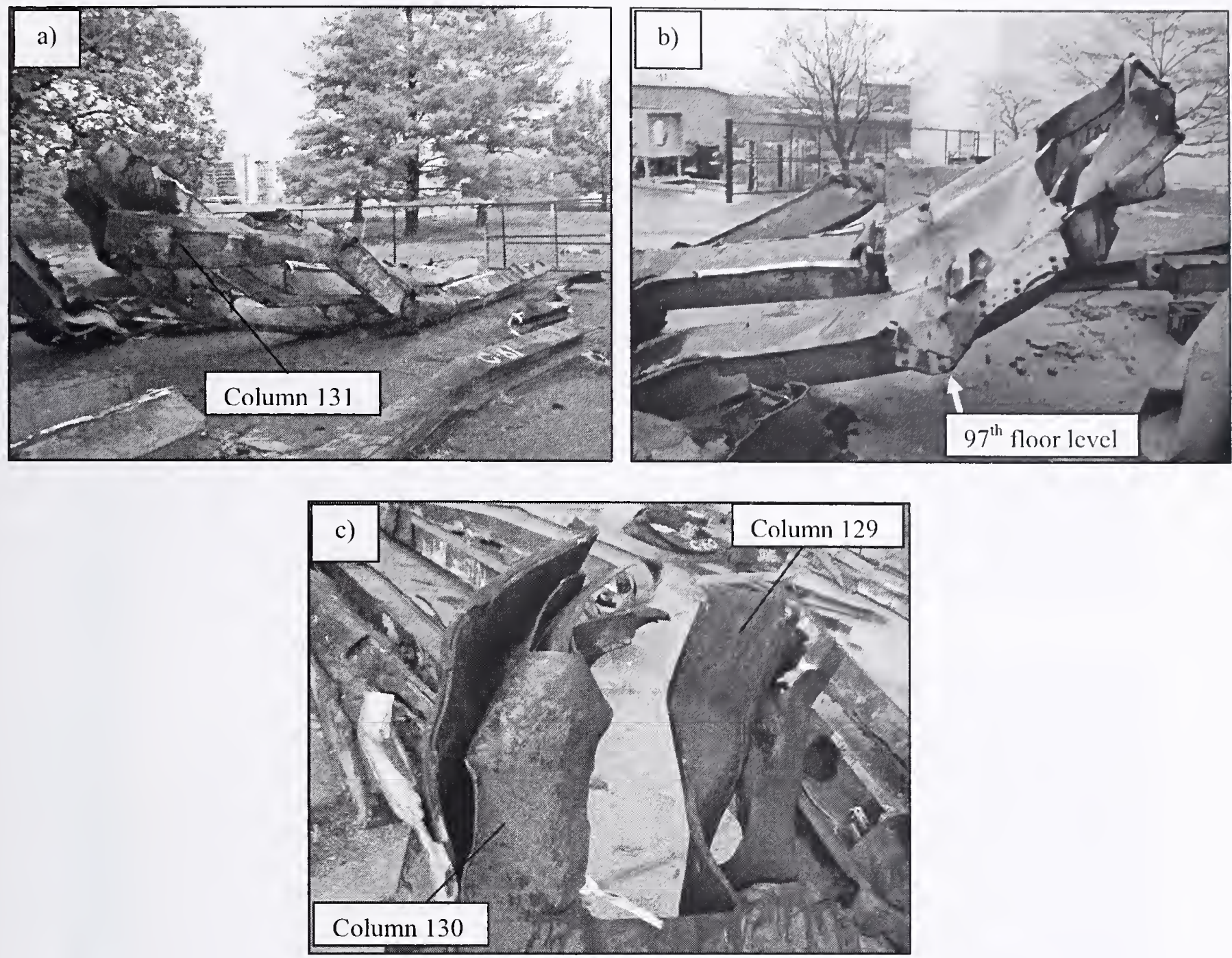

Source: NIST.

Figure 6-22. a) Overall view of panel M-2 (A130: 94-97). Bottom of panel is on the lefthand side of the picture and the outside of the panel is facing down, b) major bend in panel located at the 97th floor level, and c) splayed bottoms of columns 129 and 130. 


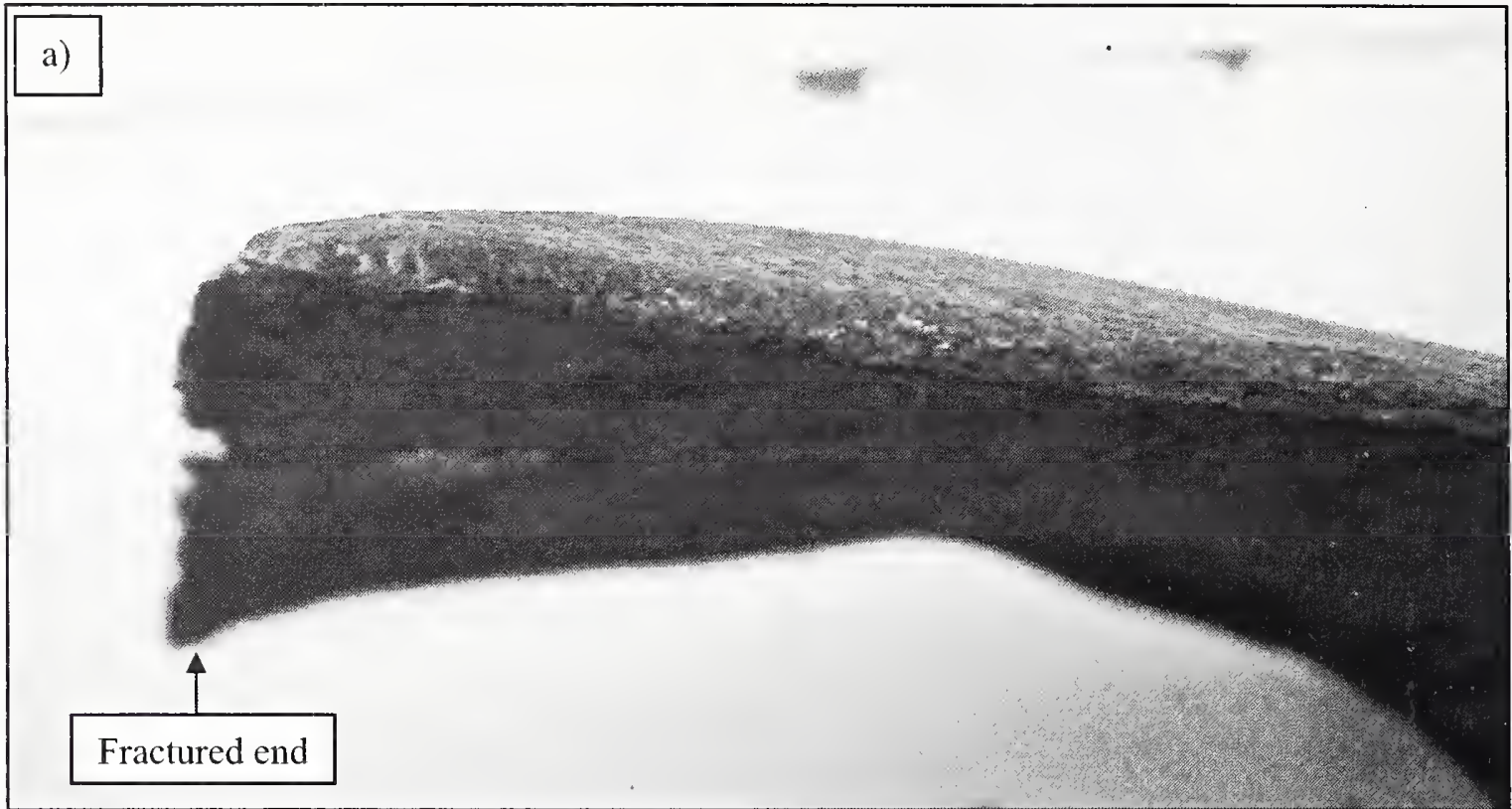

Source: NIST.

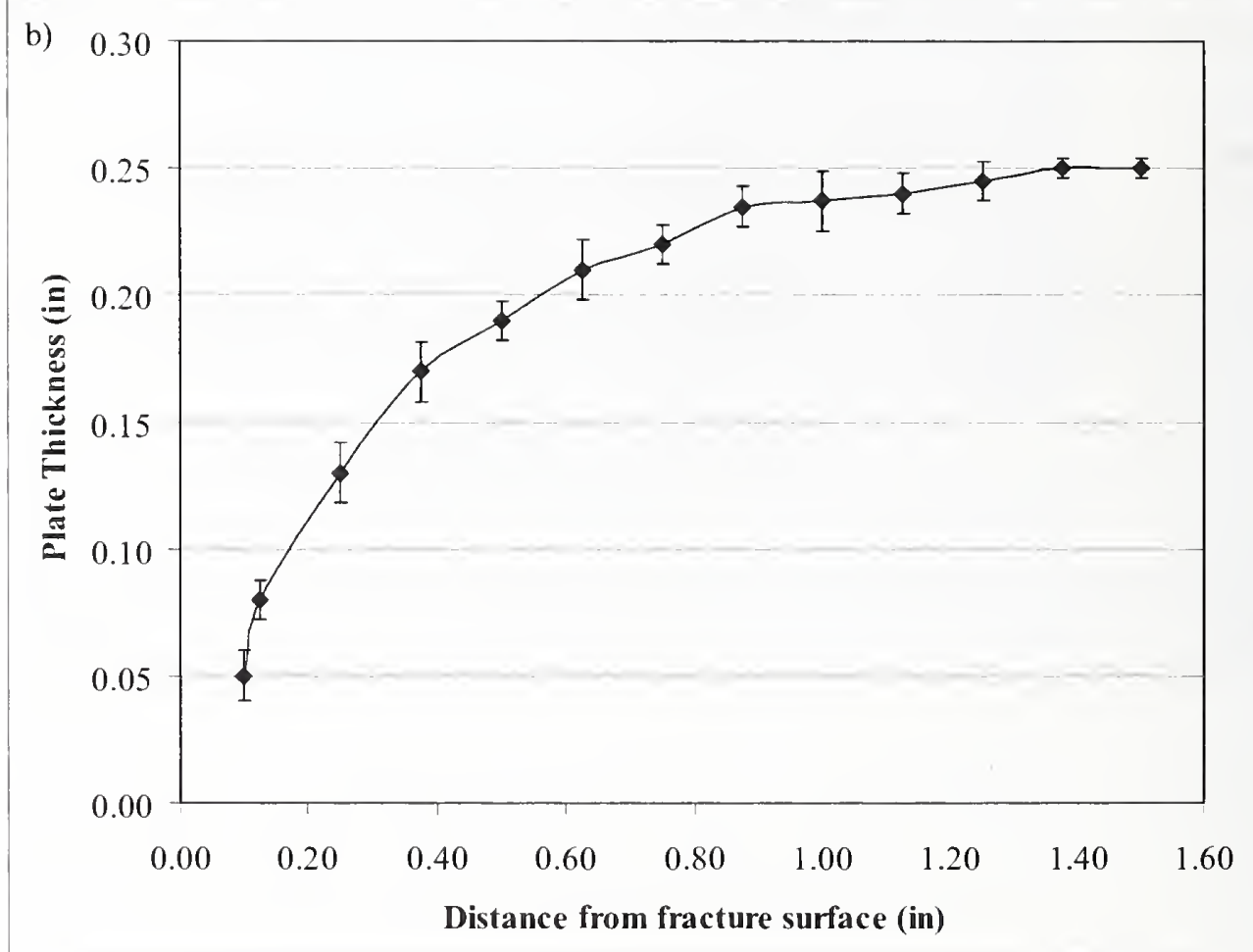

Figure 6-23. Thinning of outer web from column 130 of panel M-2 (A130: 96-99). a) Photograph showing thinning, b) graph indicating plate thinning near fracture surface. 

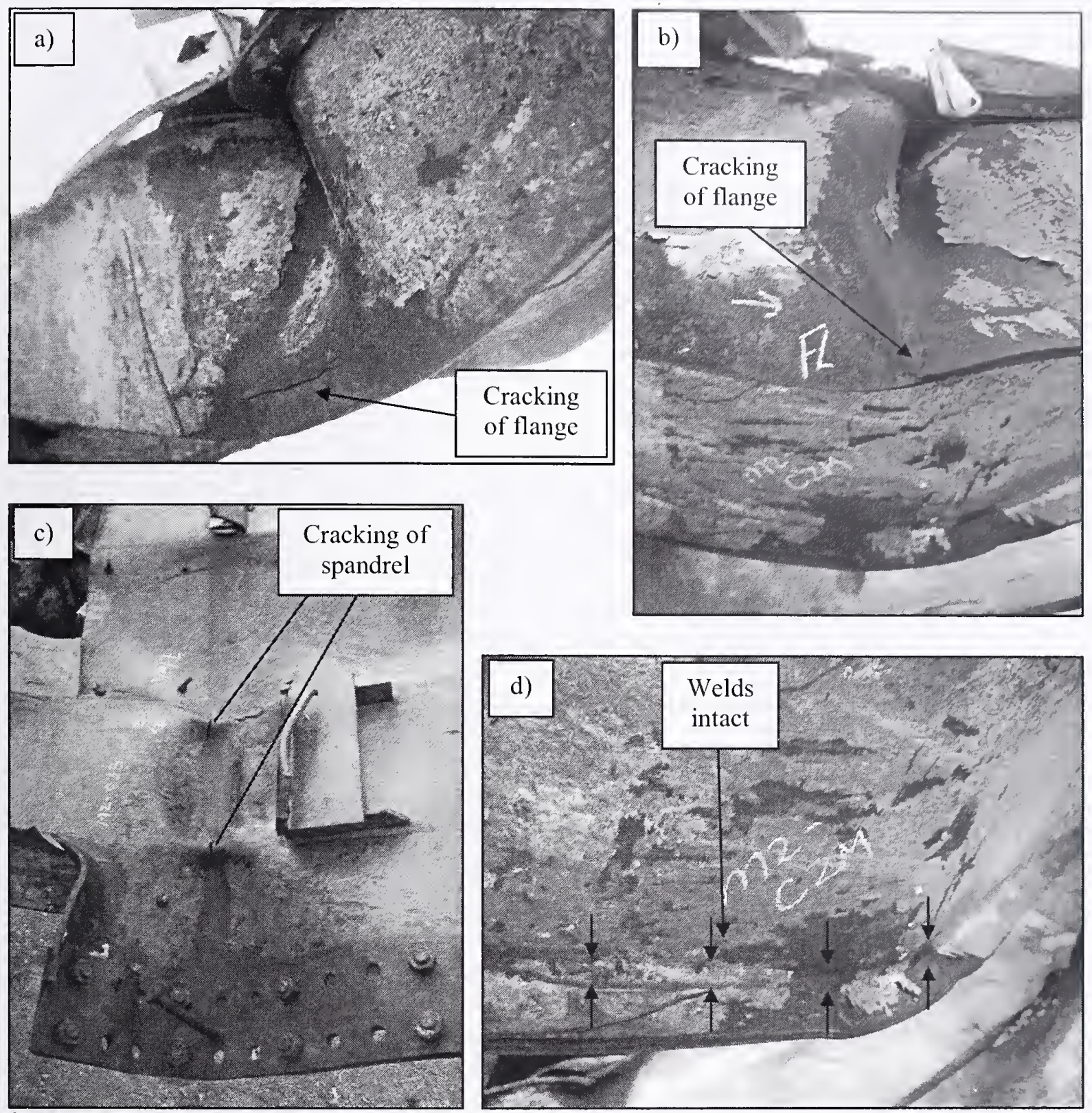

Source: NIST.

Figure 6-24. Damage images from sample M-2 (A130: 96-99). a) Large buckles observed on the flange plates of column $130, b)$ cracking of the flange plates on column 130 ,

c) cracking of spandrel at 97th floor level, and d) no cracking of the welds in this area on column 130. 
Of particular interest was the fracture behavior of the plates composing the columns that were directly impacted by the airplane. Fractures of the plates in areas away from a welded joint (e.g., fracture occurring perpendicular to the rolling direction of the outer webs of panels M-30 and S-9) exhibited ductile behavior, including necking and thinning away from the fracture, despite the high-strain ratcs.

Conversely, fractures occurring parallel and directly next to a welded joint exhibit little or no ductile characteristics. Diminished properties of the heat affected zone in the base plate, the geometry of the joint with respect to the direction of impact, stress concentrations due to the geometry, and the orientation of the crack propagation with respect to the rolling direction of the plate are expected to contribute to the lack of ductility.

\subsubsection{Exterior Wall Spandrel Connections}

As the entire panel M-2 (A130: 96-99) was recovered, all six spandrel connections were available for inspection. From pre-collapse photographs, it appears that both connections located on floor 97 failed upon impact of the airplane. Both failures were associated with tearing of the bolt holes (Fig. 6-25); the connection associated with column 131 had bolt hole tear out, and the connection nearest column 129 still retained the splice plate without the neighboring spandrel plate. The connections associated with floor 99 appeared intact, and failure may have occurred upon collapse. Those connections located on the 98th floor were obstructed by smoke, and the condition could not be determined prior to collapse. Their failures were associated with bolt hole failure, as well as fracture of the spandrel plate.

From the observations made of the spandrel connections on recovered panels, there was no difference in failure mode whether or not the panels were exposed to pre-collapse fires. There was a statistical difference in the failure modes when the location of the panels was considered. For panels at or above the impact zone, bolt hole tear out was a more common failure mode. For those samples below the impact zone, there was a higher propensity for the spandrels to be ripped off from the panels.

\subsubsection{Exterior Wali Column Splices (End Plate/Butt Plate Connections)}

The state of the recovered bottom portion of columns 129 and 130 was nearly identical to the condition after the impact for panel M-2 (A130: 96-99). Both end plates were ripped completely out of the column, Fig. 6-26. Failure was a mixture of fracture in the base plates (portion of the flange/web still attached to the end plate) and clean separation of the end plate from the flange/web (complete flange/web recovered with internal weld bead visible). Bolt hole deformation for column 131 indicated that the connection was broken by bending inward of the lower column of the connection. Finally, while bolt failure was observed at the 99th floor splice of column 129, it can be noted that some separation existed between the flange plates of the column and the endplate.

The major failure mechanism for the column splices was fracture of the bolts. Considering the 120 connections that were exclusively bolted, there were only six samples where the end plate was ripped either partially or wholly out from the column. Two of these were a direct result of the impact. For samples where the connections were welded as well as bolted (mechanical floors of the towers), fracture of the flange and web plates of the columns was the predominant mode of failure. 


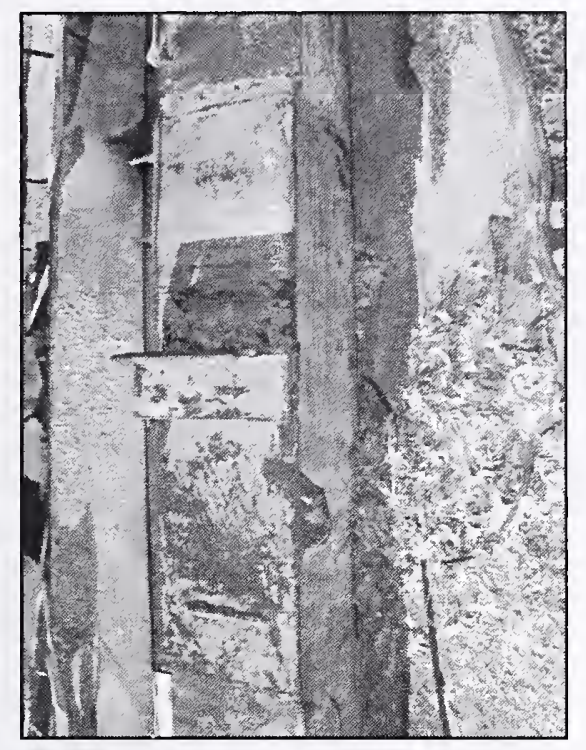

\section{M2-C1M}

Column $131,98^{\text {th }}$ floor

Spandrel Detail: 101

Failure mode: Type 3, mixed mode of fracture and bolt hole tear out, portion of spandrel from S9-C3B still attached

Orientation of image: From inside building looking out.

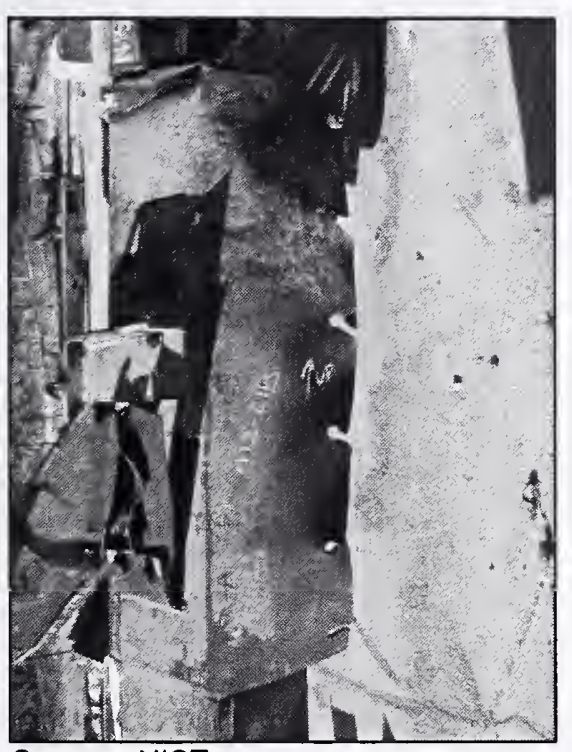

\section{M2-C1B}

Column $131,97^{\text {th }}$ floor

Spandrel Detail: 101

Failure mode: Type 1a, bolt hole tear out

Orientation of image: From inside building looking out.

Source: NIST.

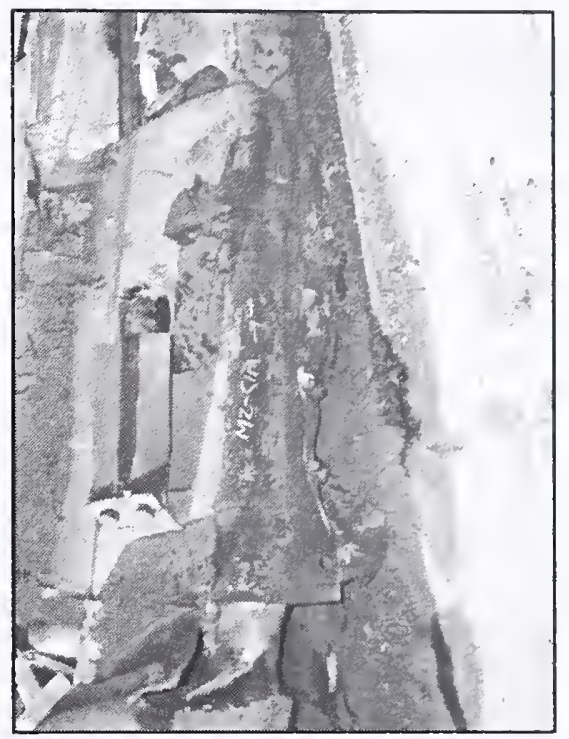

Figure 6-25. Photographs of recovered spandrel connections from sample M-2 (A130: 96-99). 


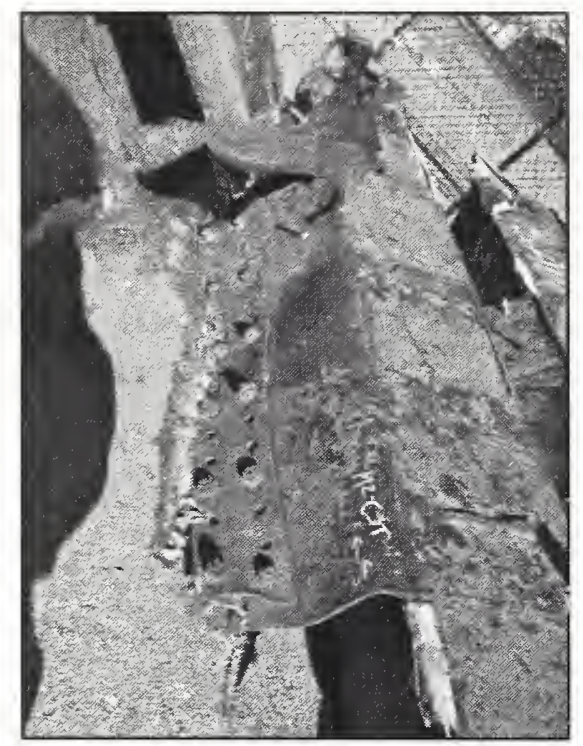

\section{M2-C3T}

Column $129,99^{\text {th }}$ floor

Spandrel Detail: 101

Failure mode: Type 1b, bolt hole tear out

Orientation of image: From inside building looking out.

\section{M2-C3M}

Column $129,98^{\text {th }}$ floor

Spandrel Detail: 101

Failure mode: Type 1a, bolt hole tear out

Orientation of image: From inside building looking out.
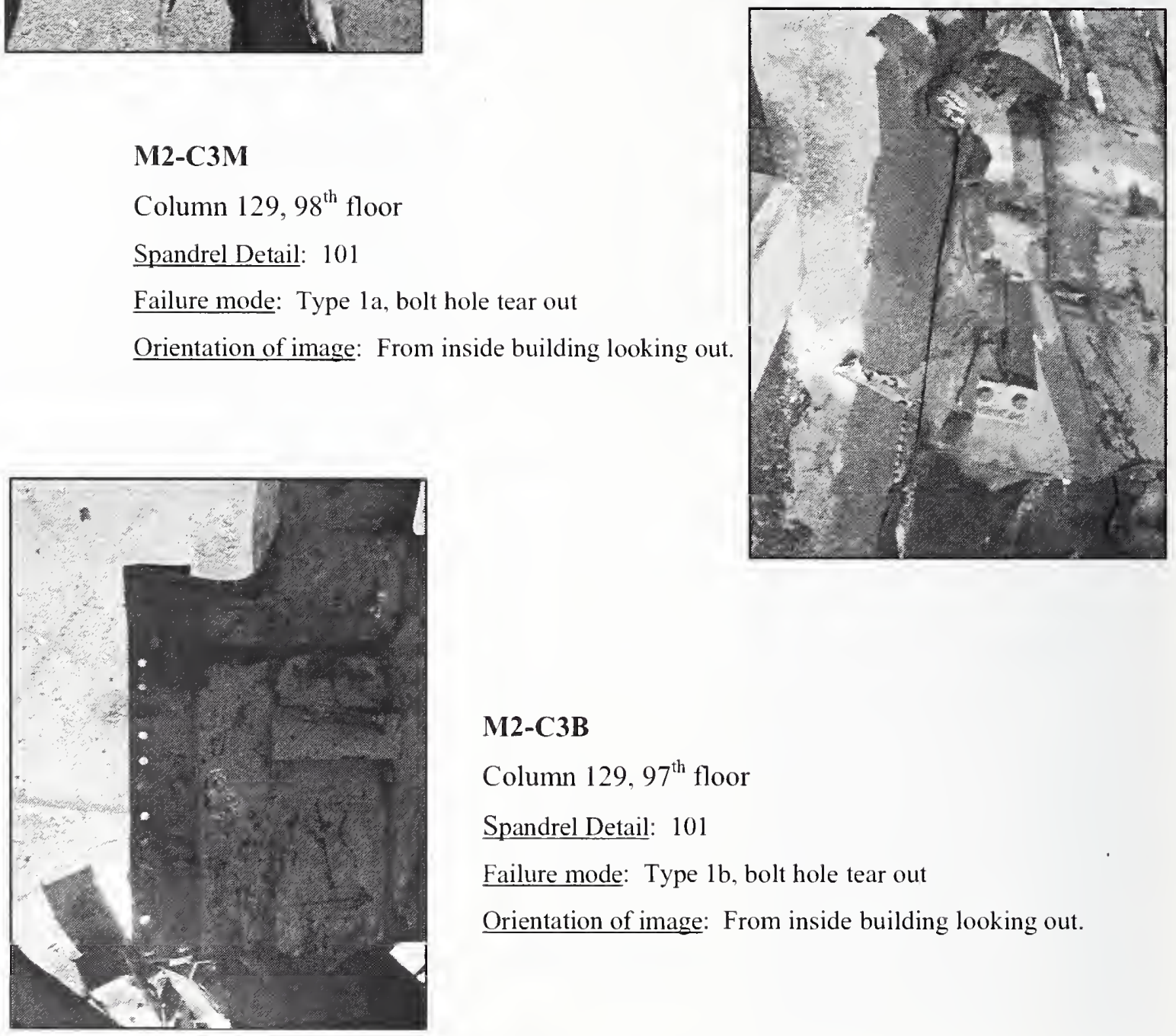

M2-C3B

Column $129,97^{\text {th }}$ floor

Spandrel Detail: 101

Failure mode: Type $1 \mathrm{~b}$, bolt hole tear out

Orientation of image: From inside building looking out.

Source: NIST

Figure 6-25. Photographs of recovered spandrel connections from sample M-2 (A130: 96-99) (continued). 

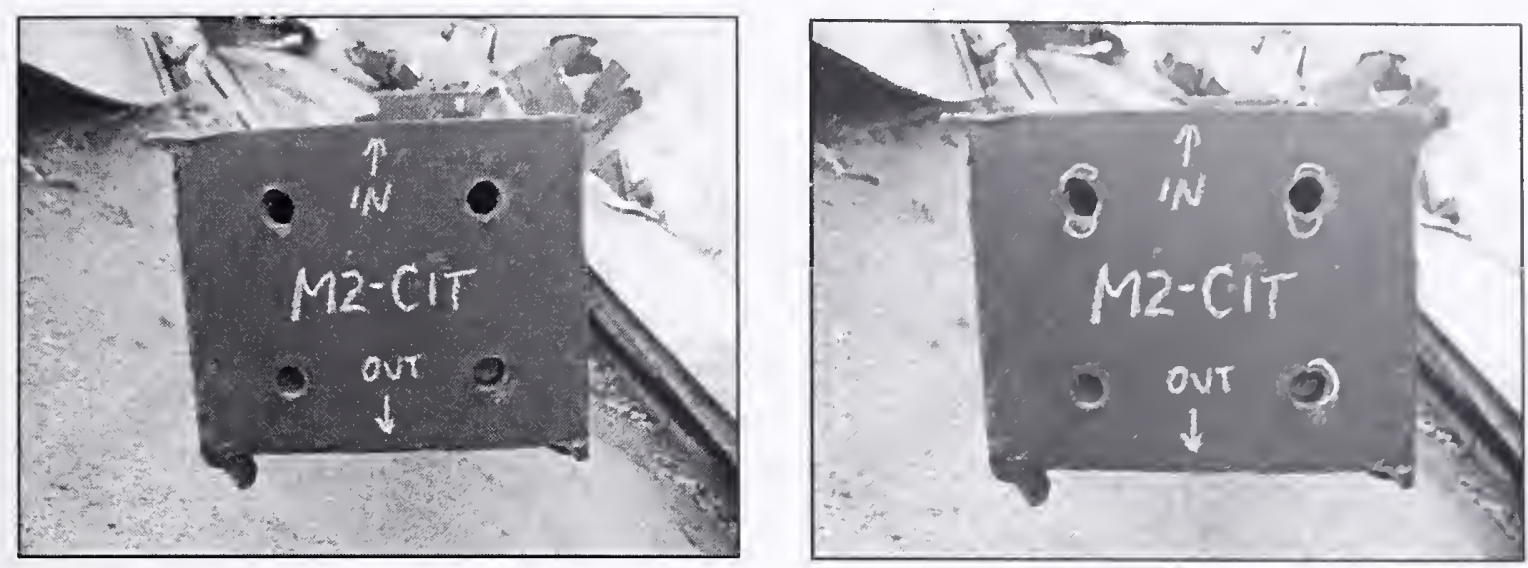

M2-C1T

\section{WTC1}

Col 131

F1 99
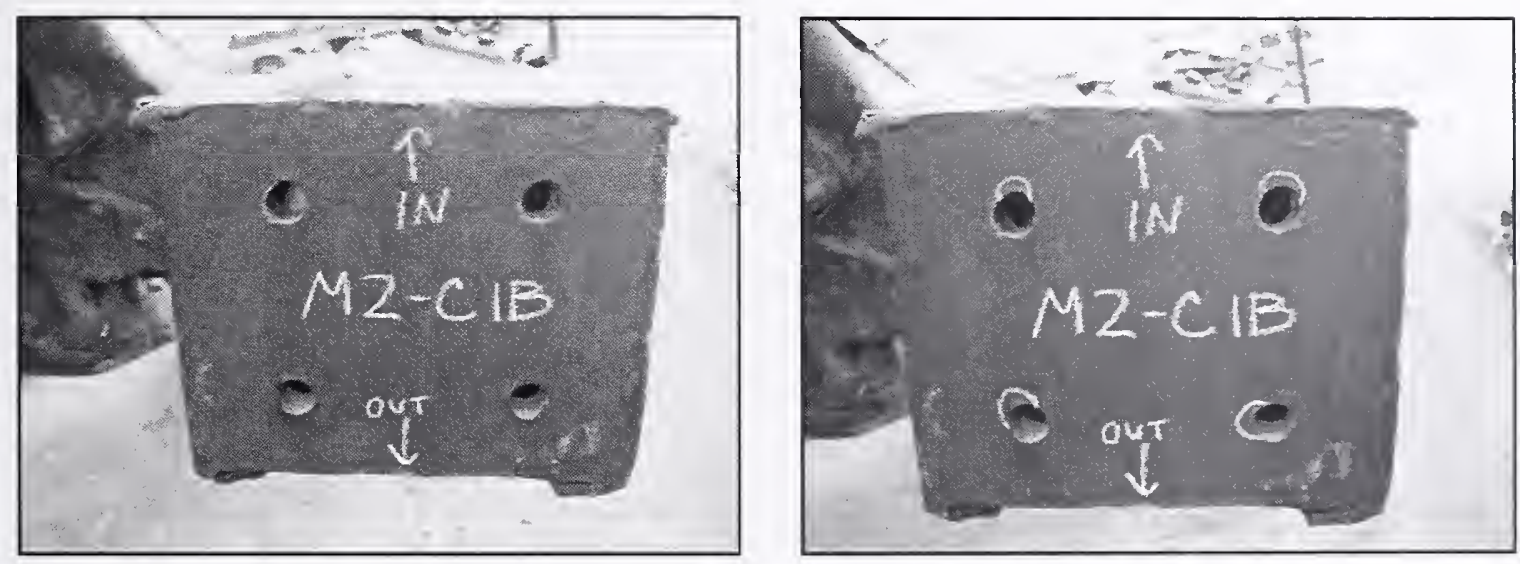

M2-C1B

WTC1

Col 131

F1 96

Source: NIST.

Figure 6-26. Photographs of recovered end plate connections from sample M-2 (A127: 97-100). Both ends of column 131 had bolt failure that resulted in deformation of the bolt holes in the end plates. 


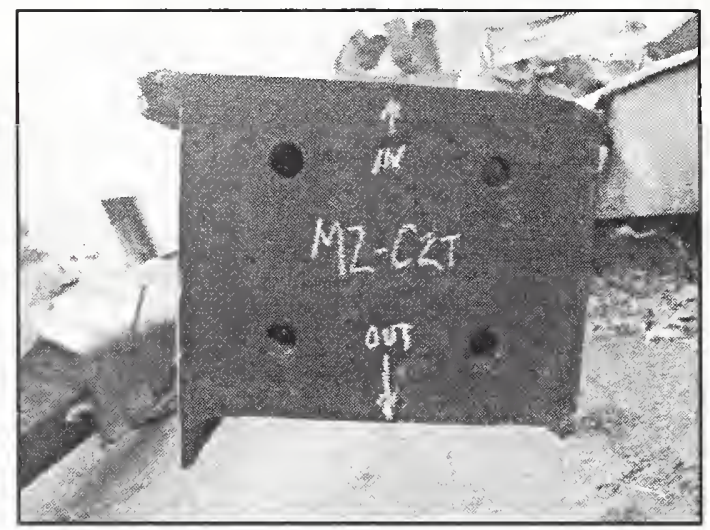

\section{No change in bolt hole shape}

M2-C2T

WTC1

Col 130

F1 99
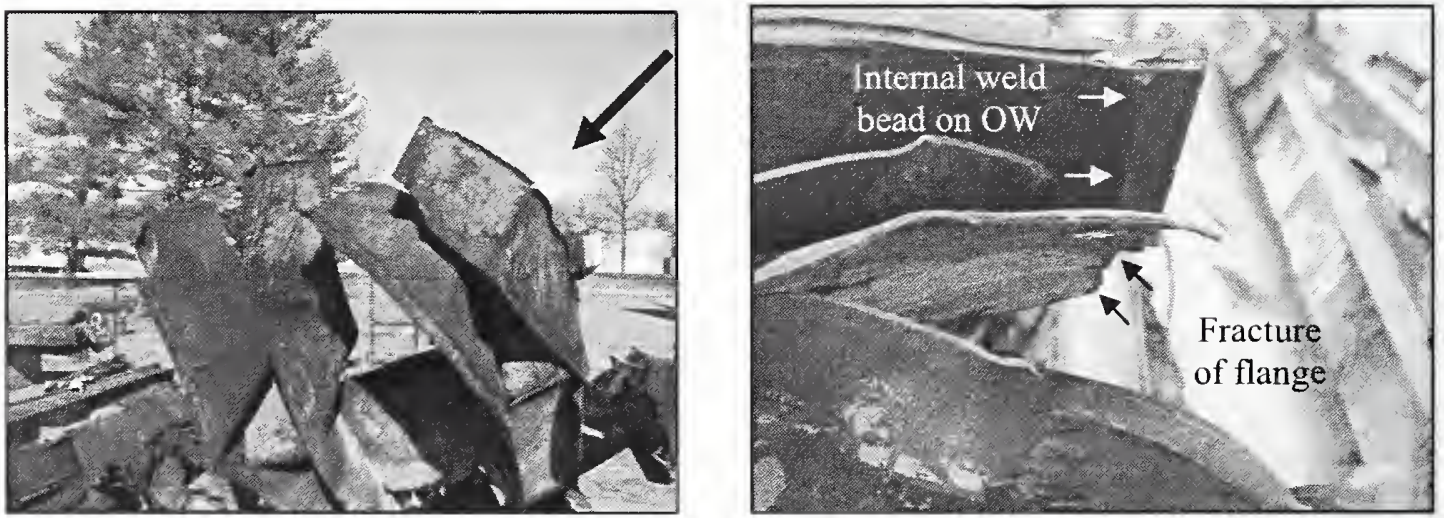

M2-C2B

\section{WTC1}

Col 130

F] 96

Source: NIST.

Figure 6-26. Photographs of recovered end plate connections from sample $\mathbf{M}-2$ (A127: 97-100). The upper end plate experienced bolt hole failure. The bottom end plate of column 130 was ripped out upon impact of the airplane. Failure was found to be a mixture of fracture in the base plates (portion of the flange/web still attached to the end plate) and clean separation of the end plate from the flange/web (complete flange/web recovered with internal weld bead visible) (continued). 

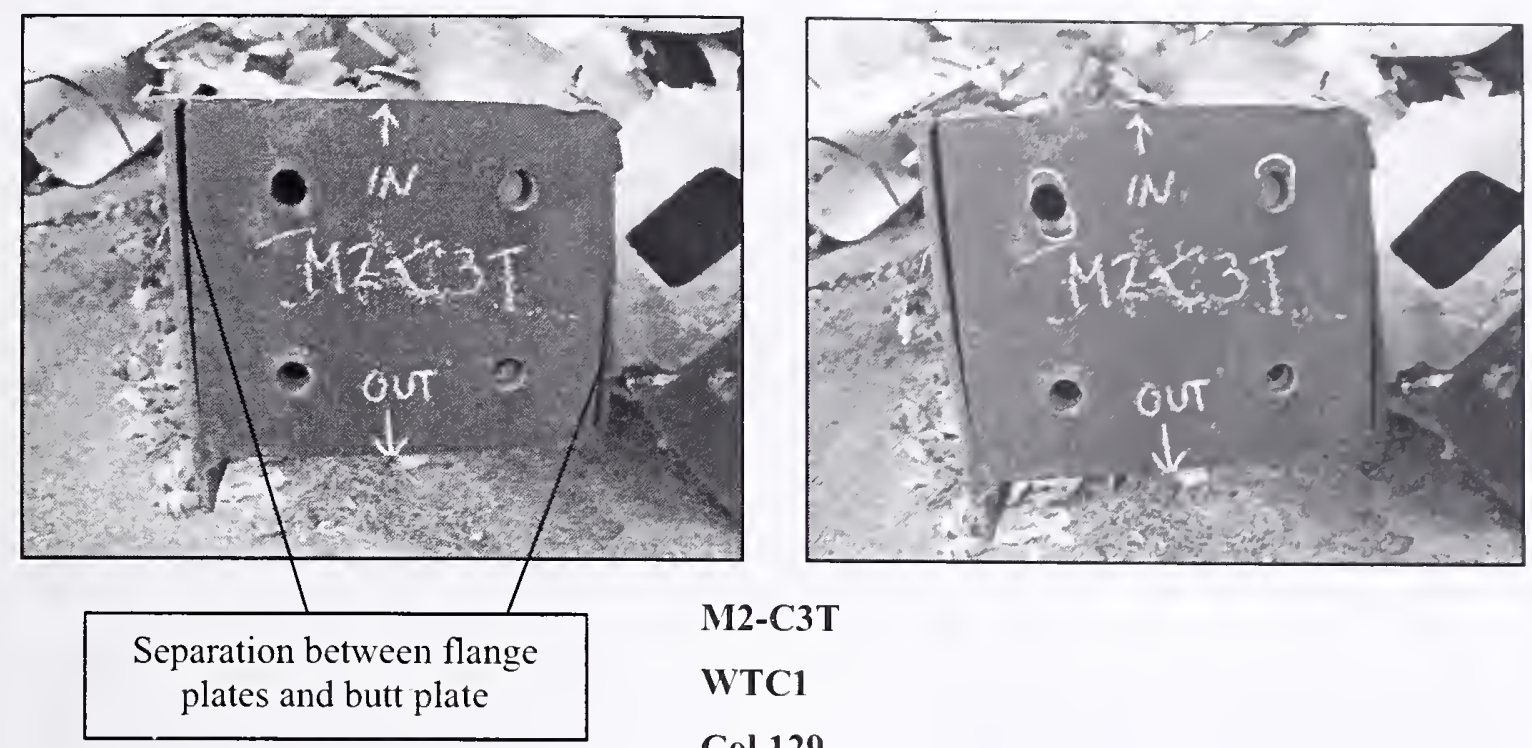

M2-C3T

WTC1

Col 129

F1 99

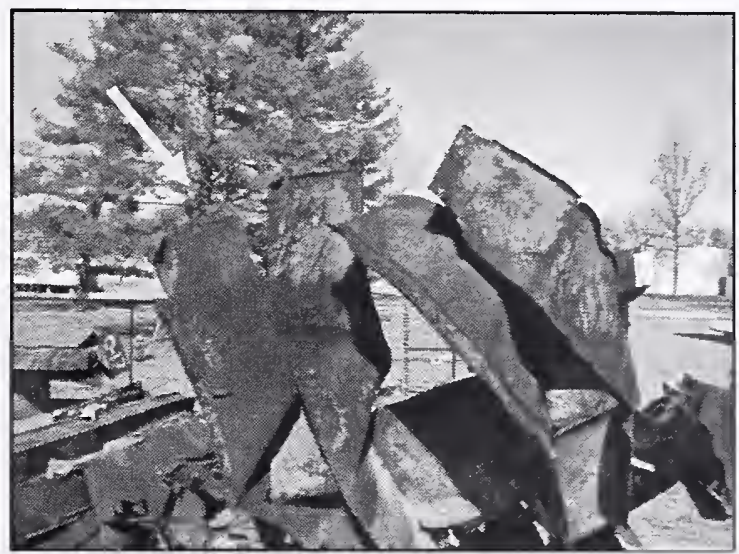

M2-C3B

WTC1

Col 129

FI 96

Source: NIST.

Figure 6-26. Photographs of recovered end plate connections from sample M-2 (A127: 97-100). The upper end plate experienced bolt hole failure. The bottom end plate of column 129 was also ripped out upon impact of the airplane. Failure was found to be a mixture of fracture in the base plates (portion of the flange/web still attached to the end plate) and clean separation of the end plate from the flange/web (complete flange/web recovered with internal weld bead visible) (continued). 


\subsubsection{Exterior Wall Seats or Floor Truss Connectors}

Panel M-2 (A130: 96-99), Fig. 6-27, is shown as an example of perimeter wall truss connections. Of the six truss seats on the panel, four were damaged but intact (e.g., bending up/down, bolt hole failure), and the other two were completely ripped off of the column. The center column of this panel also had three gusset plates, used to anchor diagonal bracing straps to provide horizontal shear transfer between the floor slab and exterior wall, as well as out-of-plane bracing for the perimeter columns not directly supporting the floor trusses. Only portions of the gusset plates remained on the middle column of the panel with the diagonal bracing straps ripped from these plates.

The most significant observations were made when the panels were categorized by their as-built elevation within the building, Fig. 6-28. Of the 28 floor truss connectors at or below the impact floors for WTC 1, 93 percent were either missing or bent downwards. Only 37 percent of the 38 floor truss connectors above the impact floors had similar characteristics. Comparable results were found for WTC 2 where 88 percent of the floor truss connectors below the impact floors were bent down or missing, while only 55 percent of the floor truss connectors above this region had such damage characteristics. This occurrence was most likely a result of the overloading of the lower floors ("pancaking" mechanism) during collapse of the building.

Missing seats were typically a result of fracture near a welded joint associated with the standoff plates. Inspection of the failures associated with the floor truss connectors showed that failure typically occurred in the component with the lowest cross-sectional area with respect to the high loading forces of the collapse. This was usually located near a welded joint. However, there was no evidence to indicate that the type of joining method chosen was improper, that the materials chosen wcre inadequate, or that inappropriate welding procedures were used.

\subsection{PHYSICAL DAMAGE OF CORE ELEMENTS (COLUMNS AND CHANNELS)}

Damage surveys were conducted on the core elements to identify and inventory the various failure modes. The identified core columns, channel material that connected the trusses to the core, and floor truss connectors (truss seats welded to the channels) wcre examined. A full discussion of these results can be found in NIST NCSTAR 1-3C.

\subsubsection{Core Columns}

Table 6-2 lists the 12 identified core columns, including as-built locations and possible conditions to which they may have been exposed prior to the collapse of the buildings. Due to the small number of samples, statistical data analysis of the damage features and failure modes would be of little use. Therefore, in-depth descriptions of the four significant pieces (C-80, C-88a, C-88b, and HH) that were located within the fire zone floors are provided below. For reference, Fig. 6-29 displays the position of the columns within the core and with respect to the perimeter panel damage. 


\section{Exterior Column Panel: M-2, Column 1}

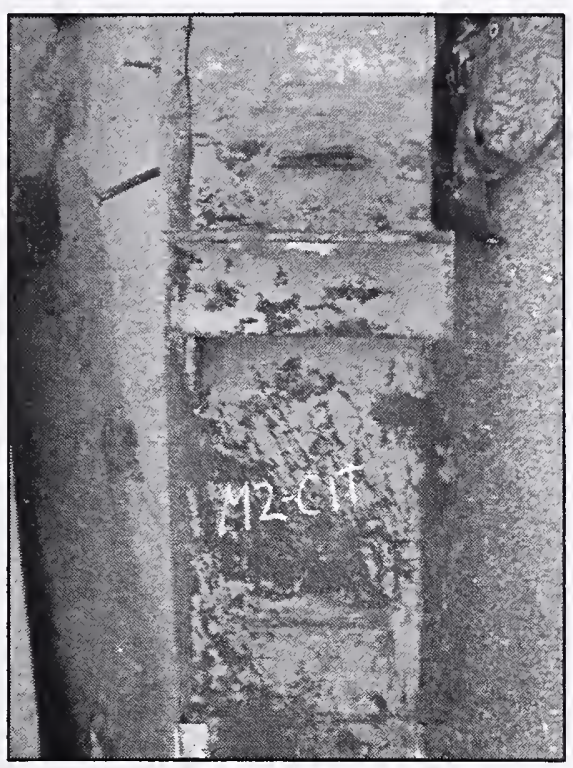

M2-C1'T (Co 131, F1 99)

Type A

Seat Detail: 1411

Tab plate remains;

Seat intact, 1 bolt hole remains intact, other ripped out;

Gusset plate for damper unit ripped off at weld.

M2-C1M (Co 131, F1 98)

Type A

Seat Detail: 1411

Tab plate intact;

1 standoff plate remains, seat and other standoff plate ripped off at welds;

Gusset plate with damper unit intact, bent up.
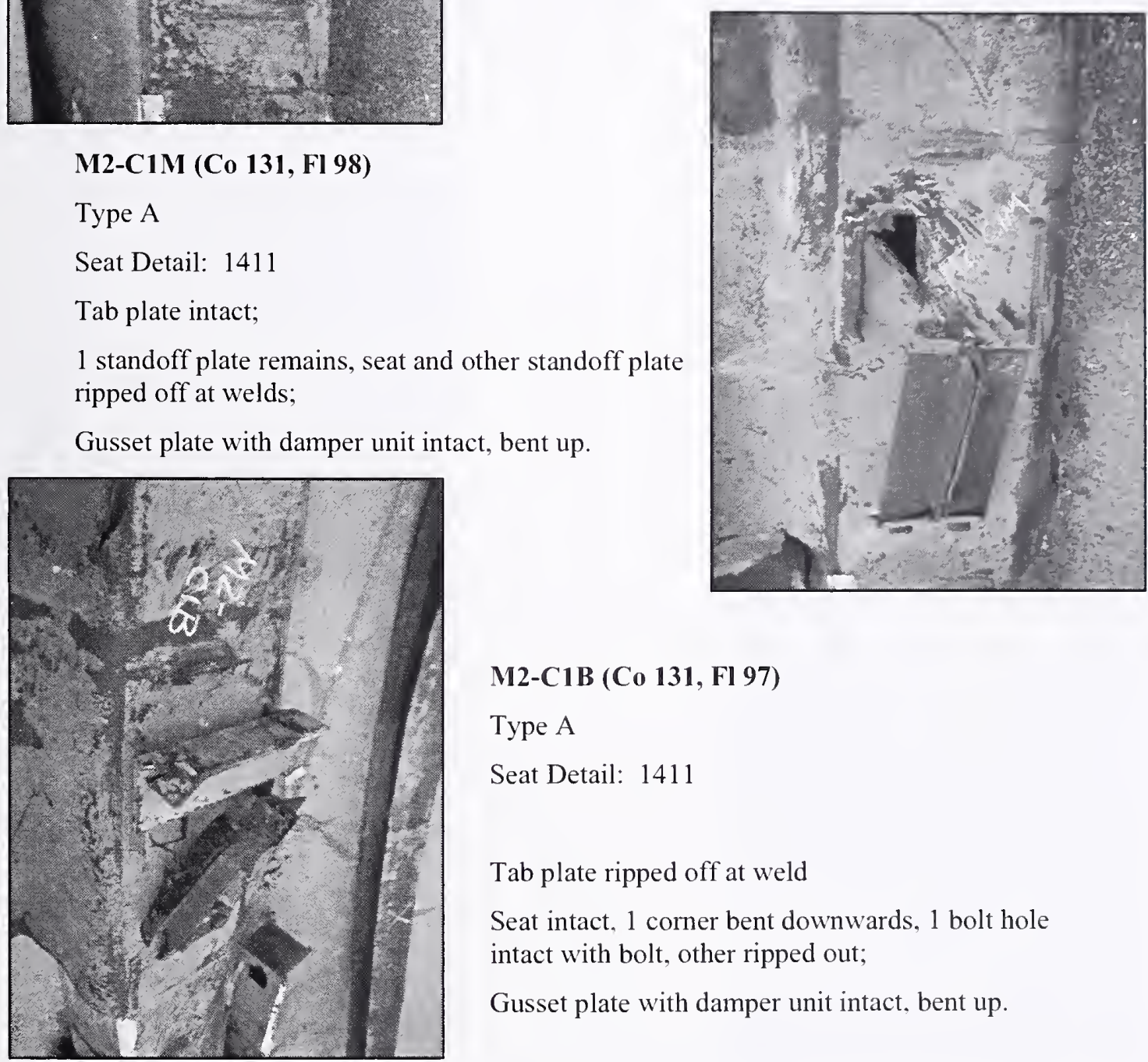

M2-C1B (Co 131, F1 97)

Type A

Seat Detail: 1411

Tab plate ripped off at weld

Seat intact, 1 corner bent downwards, 1 bolt hole intact with bolt, other ripped out;

Gusset plate with damper unit intact, bent up.

Figure 6-27. Floor truss connectors for panel M-2 (A130: 96-99). 


\section{Exterior Column Panel: M-2, Column 2}

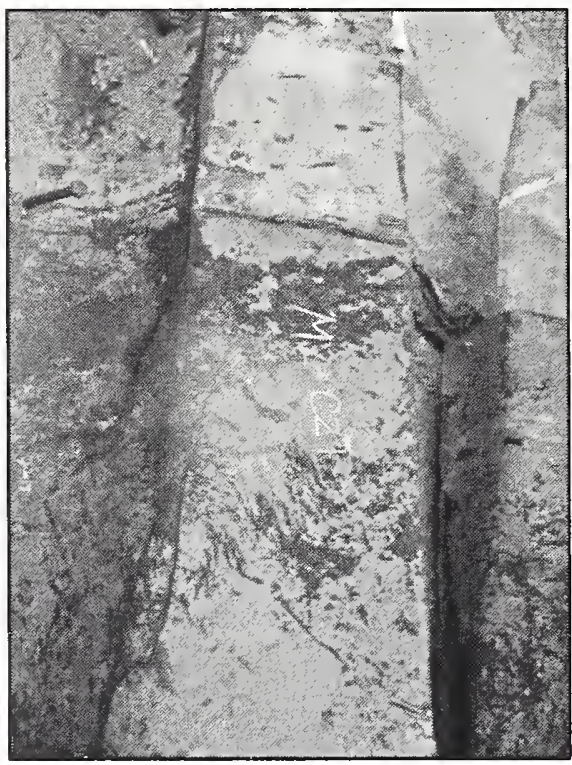

M2-C2M (Co 130, Fl 98)

Type C

Seat Detail: 5210

Portion of tab plate remains, bent up.

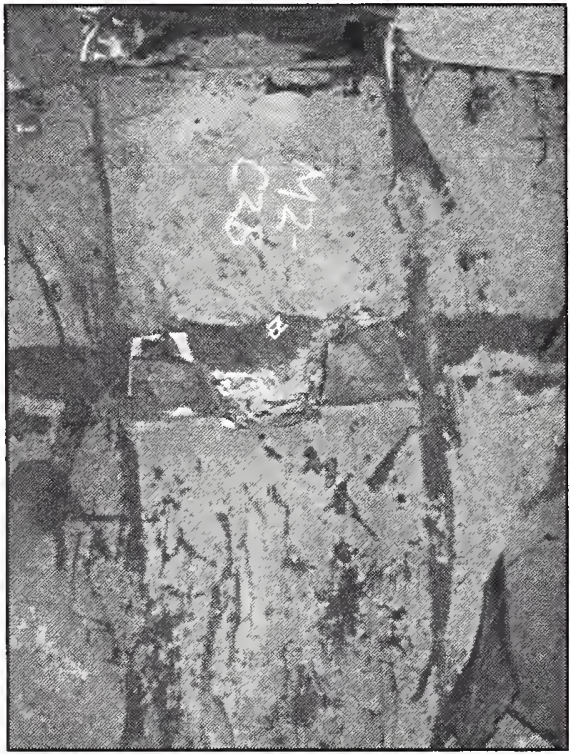

Source: NIST
M2-C2T (Co 130, F1 99)

Type C

Seat Detail: 5210

Tab plate ripped off at weld.

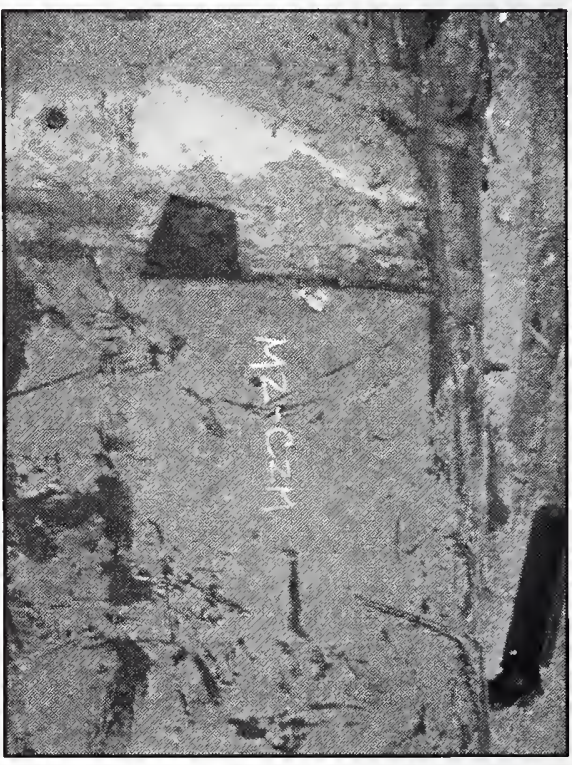

M2-C2B (Co 130, 97)

Type C

Seat Detail: 5210

Tab plate remains, bent up.

Figure 6-27. Floor truss connectors for panel M-2 (A130: 96-99) (continued). 


\section{Exterior Column Panel: M-2, Column 3}

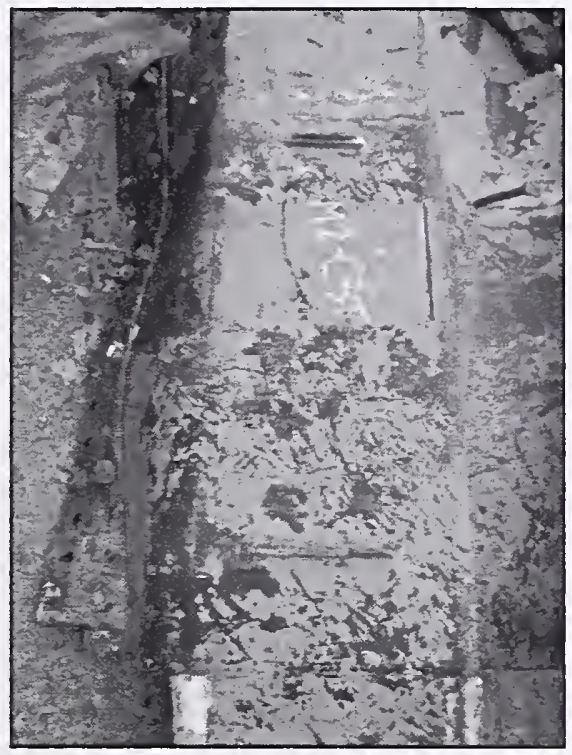

M2-C3T (Co 129, Fl 99)

Type A

Seat Detail: 1411

Tab plate ripped off at weld;

Standoff plates ripped off at welds;

M2-C3M (Co 129, F1 98)

Type A

Seat Detail: 1411

Tab plate remains;

Seat intact, bent down, 1 bolt hole remains intact with bolt, other ripped out;

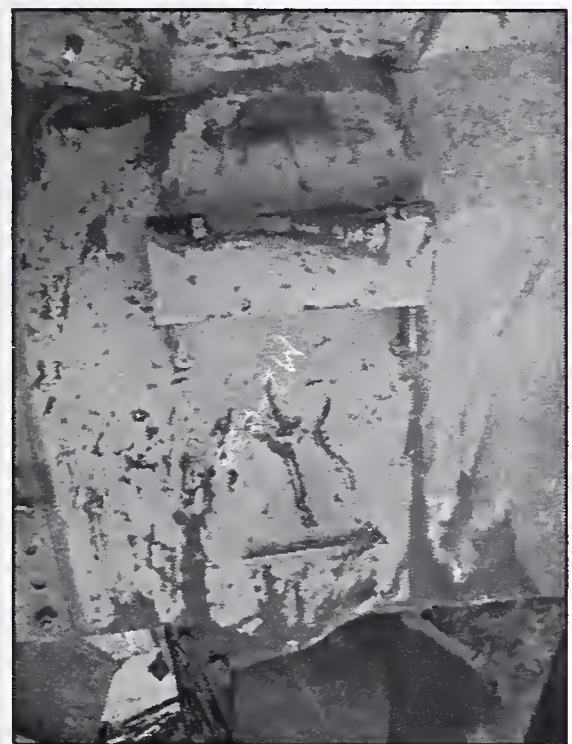

Source: NIST.

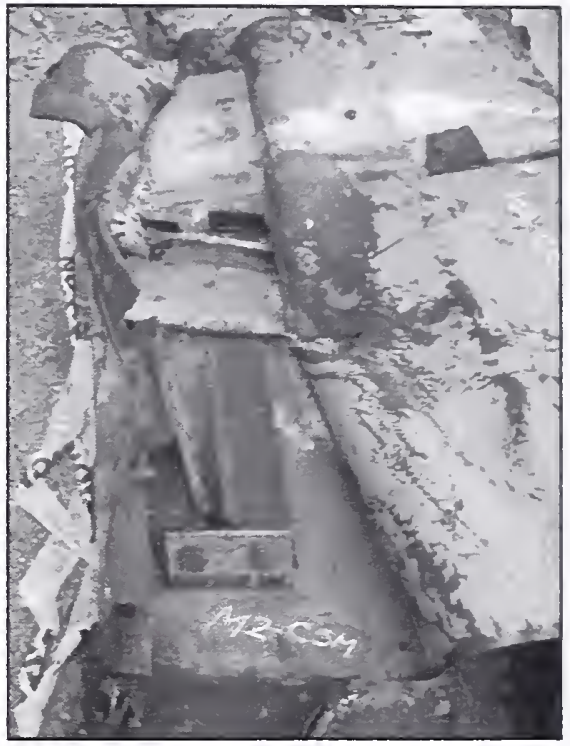

N12-C3B (Co 129, F1 97)

Type A

Seat Detail: 1411

Tab plate ripped off at weld;

Seat intact, bent down. 1 bolt hole remains intact. other ripped out;

Figure 6-27. Floor truss connectors for panel M-2 (A130: 96-99) (continued). 


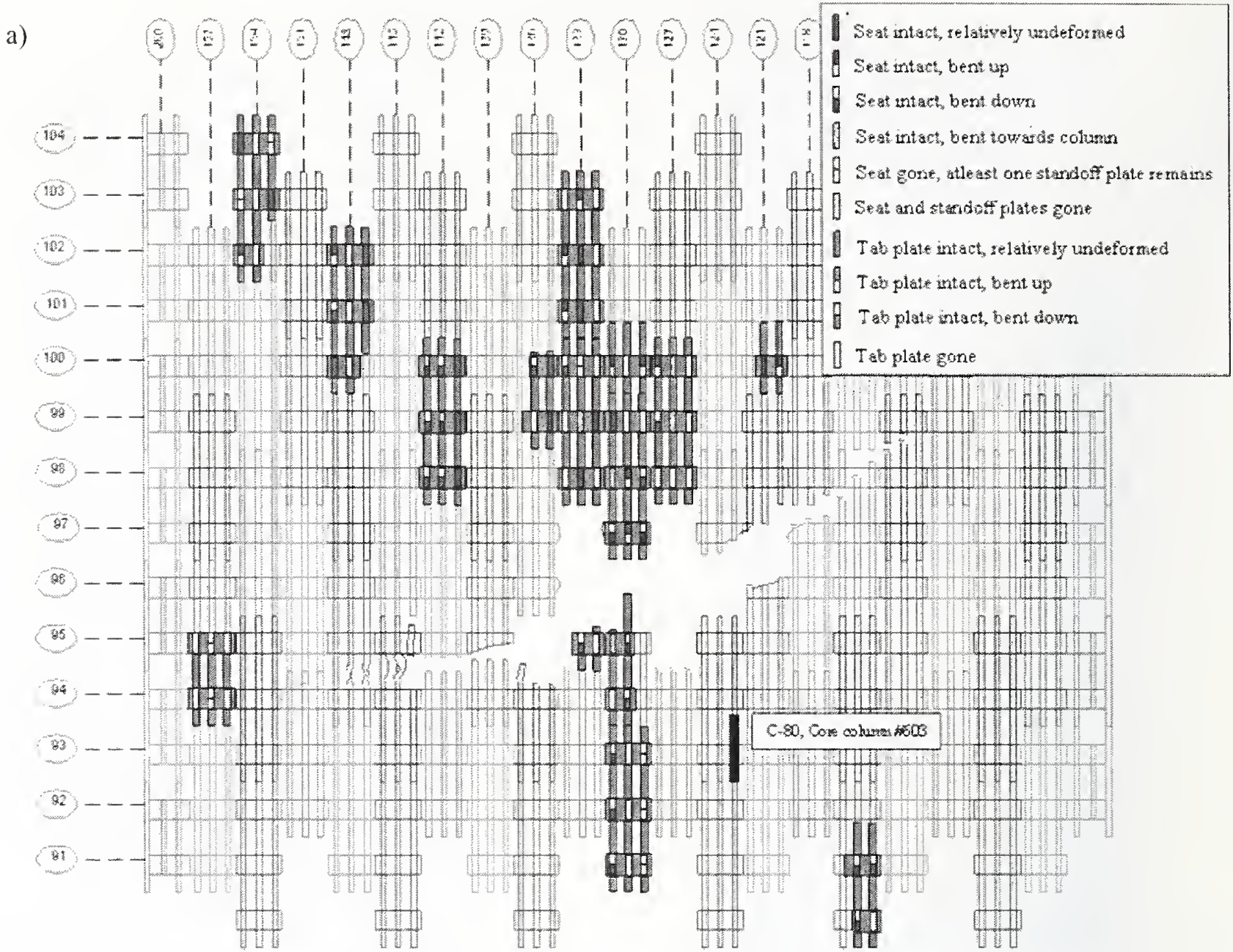

Figure 6-28a. Damage diagram overlaid with recovered samples and damage of connectors. 
b)

108

801

Bd

$\begin{array}{ll}801 & \\ 801 & \\ 10 & 801 \\ & 800 \\ 801\end{array}$

\section{0}

비는

110

1080000880

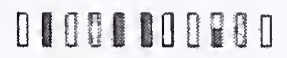

01008000

\section{明是}

Seat intact, $x \in$ latively urideformed

S Seat wact, ben: up

D Seal sntact, bent dour

Seat aritact, bert iowards colurtor

B Seat gore, atleast one staridoff plate $1 \in$ mains

I Seat und studioff pilates zore

T Tab plate intuct, relatively undefor med

G Tab plate initact, bent up

I Iat plate intact, bert coum

Tab plate gone

$95^{\text {th }}$ floor level

OQ]

0日勺

Figure 6-28b. Damage of connectors. At or below the 95th floor, all connectors are
either bent down or missing.
80日

[1日

80日

日0日

B日B
目口

88 
Table 6-2. Recovered core columns with known as-built locations, separated by pre-collapse conditions.

\begin{tabular}{|c|c|c|c|c|c|c|c|}
\hline \multirow{2}{*}{ Column Description } & \multirow{2}{*}{ Bldg } & \multirow{2}{*}{ NIST Name } & \multirow{2}{*}{ Brief Description } & \multirow{2}{*}{ Column \# } & \multicolumn{2}{|c|}{ Story at Splice } & \multirow{2}{*}{ Fy } \\
\hline & & & & & Lower & Upper & \\
\hline \multirow{3}{*}{$\begin{array}{l}\text { Core columns within } \\
\text { impact region }\end{array}$} & WTC 1 & C-80 & Wide flange & 603 & 92 & 95 & 36 \\
\hline & WTC 2 & C-88b & Built-up box beam & 801 & 77 & 80 & 42 \\
\hline & WTC 2 & $C-88 a$ & Euilt-up box beam & 801 & 80 & 83 & 42 \\
\hline \multirow{2}{*}{$\begin{array}{c}\text { Core columns within fire } \\
\text { exposure zone }\end{array}$} & WTC 1 & $\mathrm{HH}$ or $\mathrm{S}-2$ & Wide flange & 605 & 98 & 101 & 42 \\
\hline & WTC 2 & none & & & & & \\
\hline \multirow{8}{*}{$\begin{array}{l}\text { Core columns outside of } \\
\text { fire exposure zone }\end{array}$} & WTC 1 & B-6152-2 & Built-up box beam & 504 & 33 & 36 & 36 \\
\hline & WTC 1 & B-1011 & Built-up box beam & 508 & 51. & 54 & 36 \\
\hline & WTC 1 & B-6152-1 & Built-up box beam & 803 & 15 & 18 & 36 \\
\hline & WTC 1 & C. 71 & Wide flange & 904 & 77 & 80 & 36 \\
\hline & WTC 1 & $C-155$ & Wide flange & 9014 & 83 & 86 & 36 \\
\hline & WTC 1 & C-65 or $\mathrm{S}-8$ & Wide flange & 904 & 86 & 89 & 36 \\
\hline & WTC 2 & C-90 & Built-up box beam & 701 & 12 & 15 & 36 \\
\hline & WTC 2 & $\mathrm{C}-30$ or $\mathrm{S}-12$ & Wide flange & 1008 & 104 & 106 & 36 \\
\hline
\end{tabular}

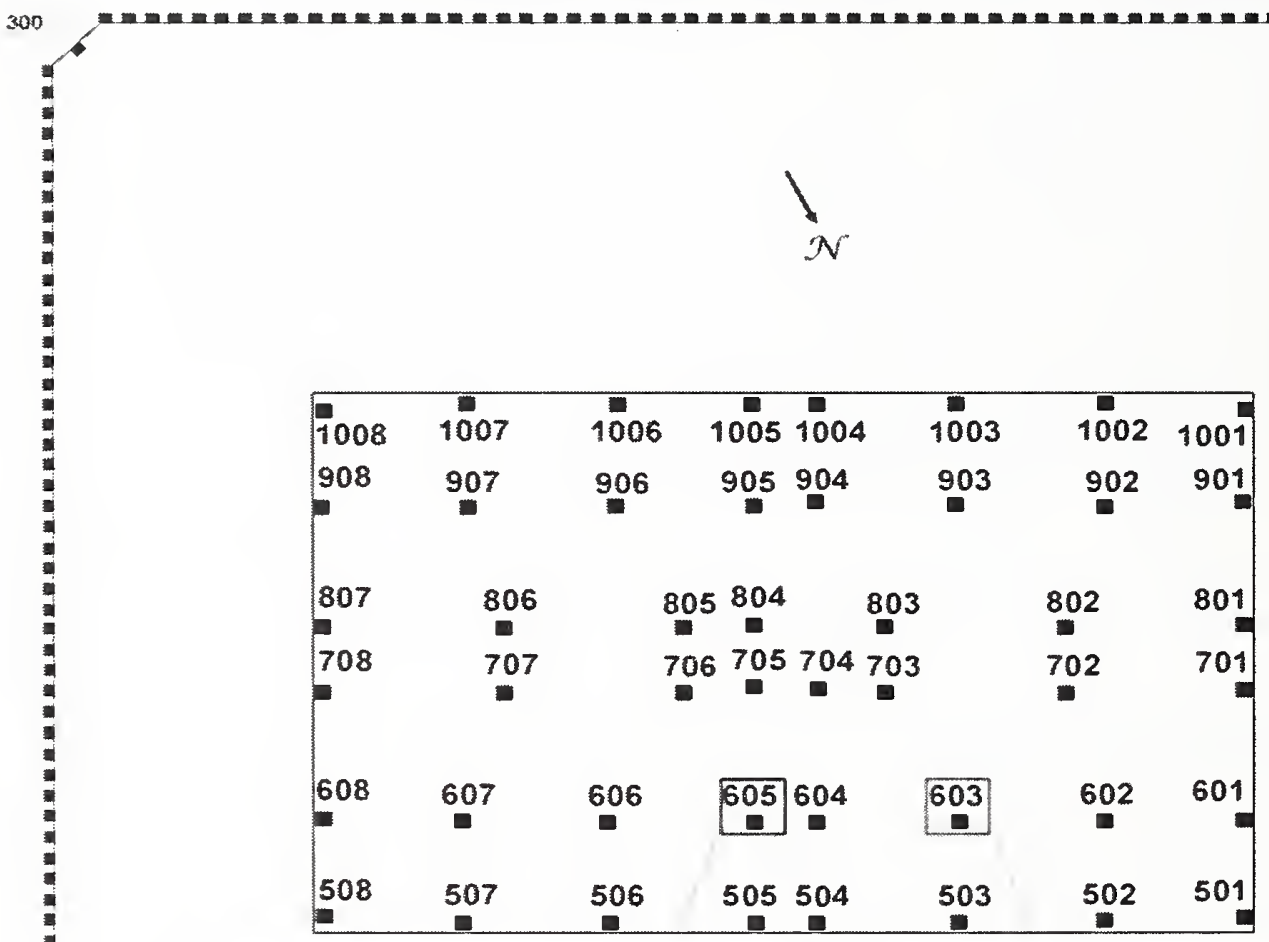

HH, 605A: 98-101 (wide flange)

C-80, 603A: 92-95 (wide flange)

Estimated impact damage to exterior wall 200

$\begin{array}{llllllllllllllllllllll}159 & 157 & 154 & 151 & 148 & 945 & 142 & 139 & 136 & 133 & 130 & 127 & 124 & 121 & 118 & 115 & 112 & 109 & 106 & 103 & 101\end{array}$

Figure 6-29a. Positioning of the recovered core columns with the core area for WTC 1. 


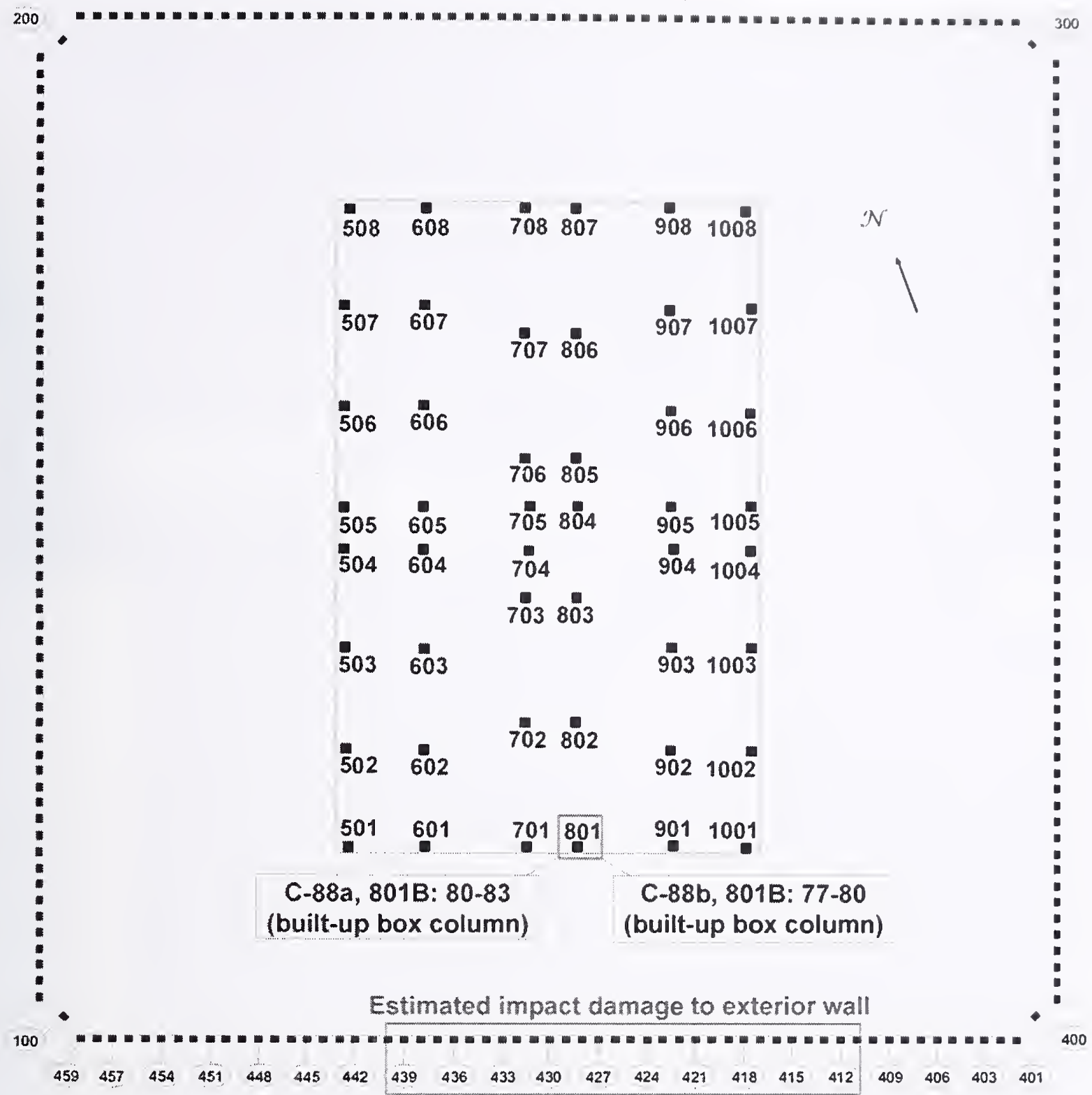

Figure 6-29b. Positioning of the recovered core columns with the core area for WTC 2.

Sample C-80 (Fig. 6-30a), from WTC 1, was a 36 ksi wide-flange located in the middle of the second row of core columns along the north face. Only the lower third of the column was recovered (approximately $13 \mathrm{ft}$ ). The location of the column indicated that it did not sustain impact damage.

Consistent with the column's position, modeling results indicated that this column was not in the path of the aircraft debris (NIST NCSTAR 1-2). Different failure modes were observed for each end (Figs. 6-30b and 6-30c). Bolt fracture occurred at the lower portion of the column (92nd floor region). while the upper portion of the wide-flange was torn through its section (near the 93rd floor region). No visible necking (localized reduction in area) was observed in the immediate vicinity of the fracture. 

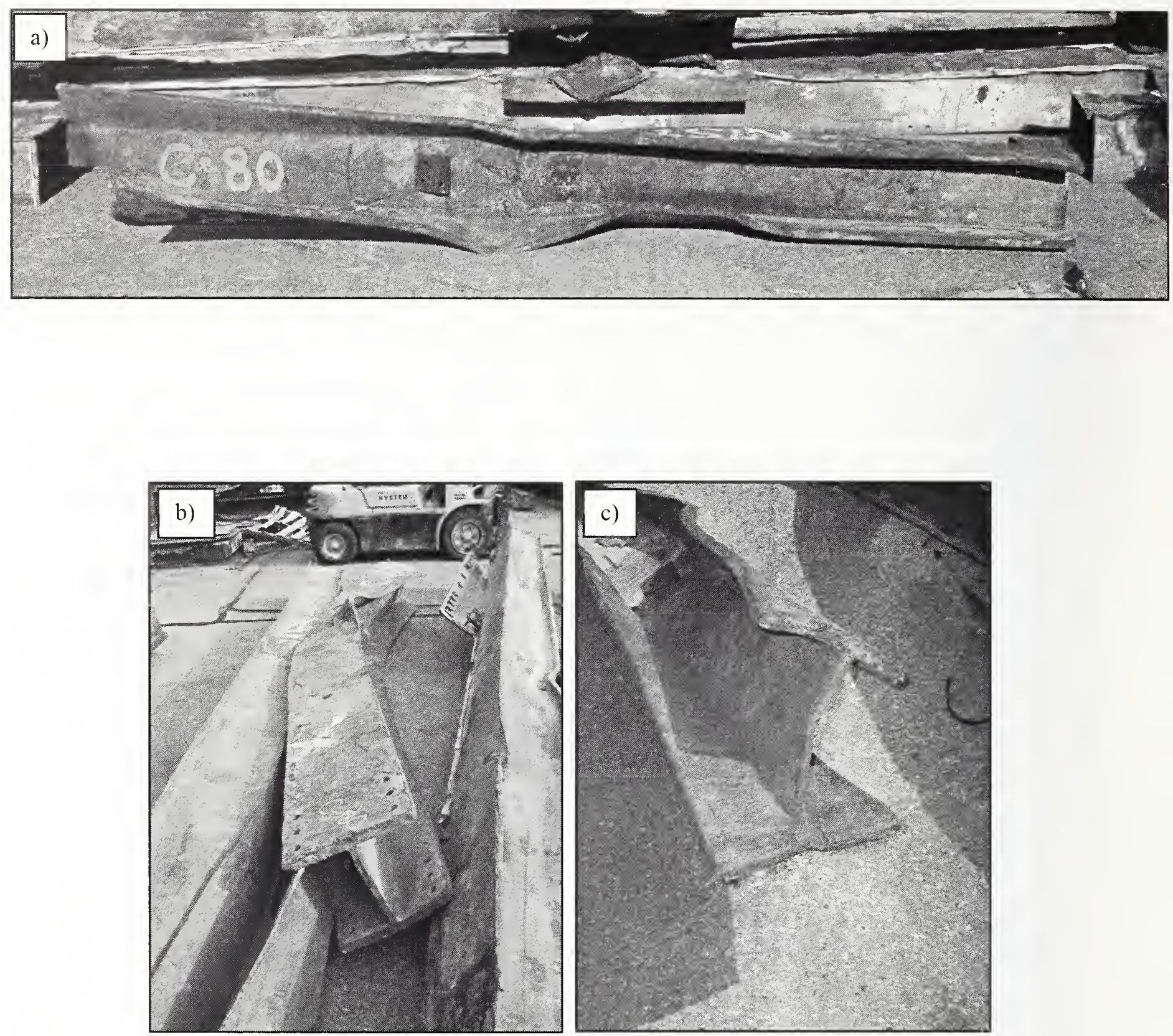

Source: NIST.

Figure 6-30. Core column C-80 (603A: 92-95). a) Overall view of recovered column, b) view of connection in the 92 nd floor region, failure as a result of bolt fracture, and c) torn end of column near the 94 th floor region.

Core columns C-88a and C-88b, from WTC 2, were unique among the recovered core elements in that the columns were still connected at the welded column splice, Fig. 6-31. Both columns were 42 ksi built-up box columns with their shared splice in the 80 th floor level. The lower $16 \mathrm{ft}$ of C-88a was recovered (floors 80 through 82 ), whereas the upper $8 \mathrm{ft}$ of $\mathrm{C}-88 \mathrm{~b}$ was still attached (primarily within the 80 th floor). The location of the column C-88b suggested that impact damage may have been sustained. Both webs and the "south" flange were severely bent to the east and had flame cut ends, Fig. 6-32. The bends occurred just below the connector for the channel associated with the 80 th floor. The "north" 


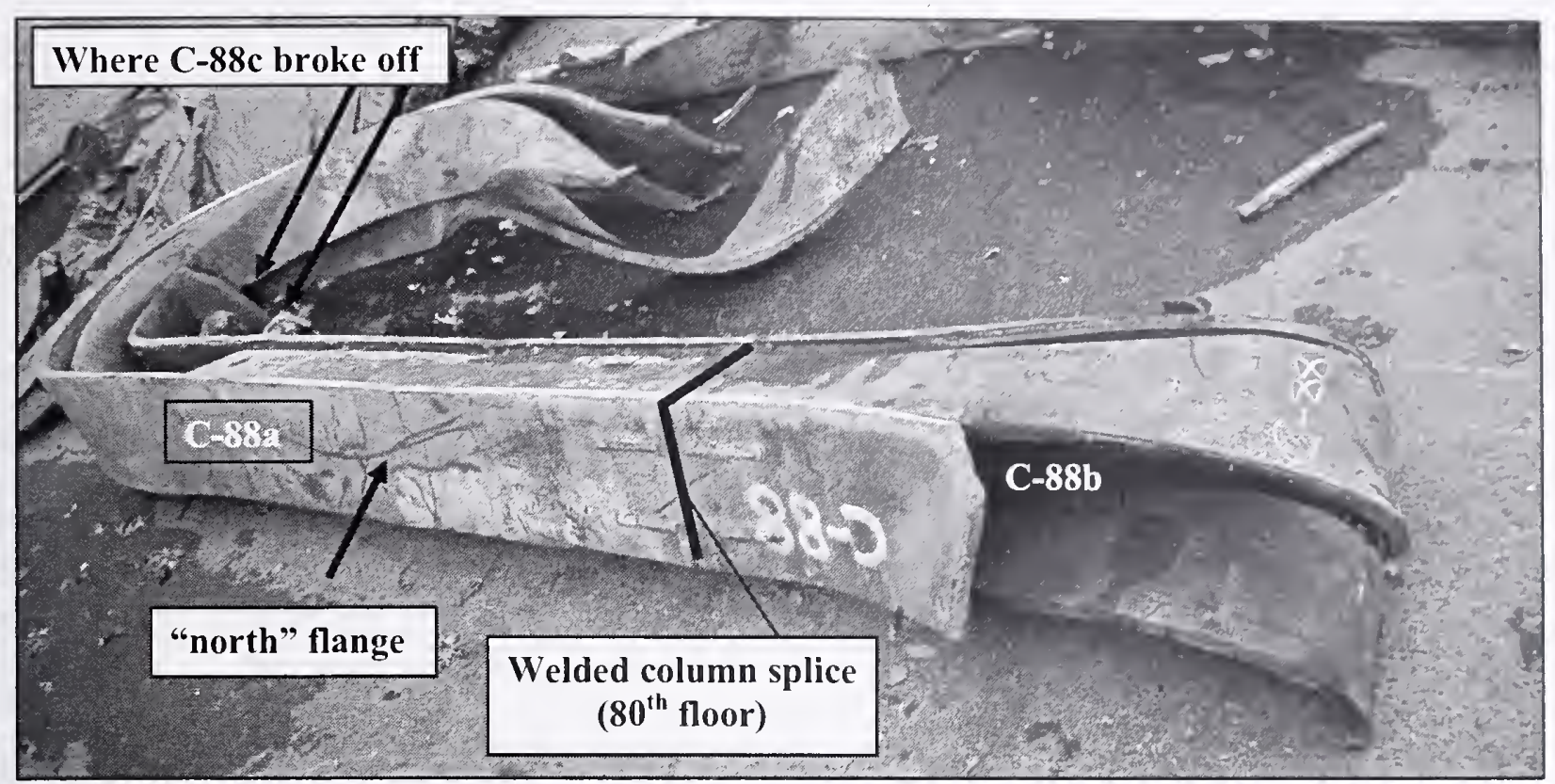

Source: NIST.

Figure 6-31. Overall view of recovered core columns C-88a (801B: $80-83)$ and C-88b (801B: 77-80). 

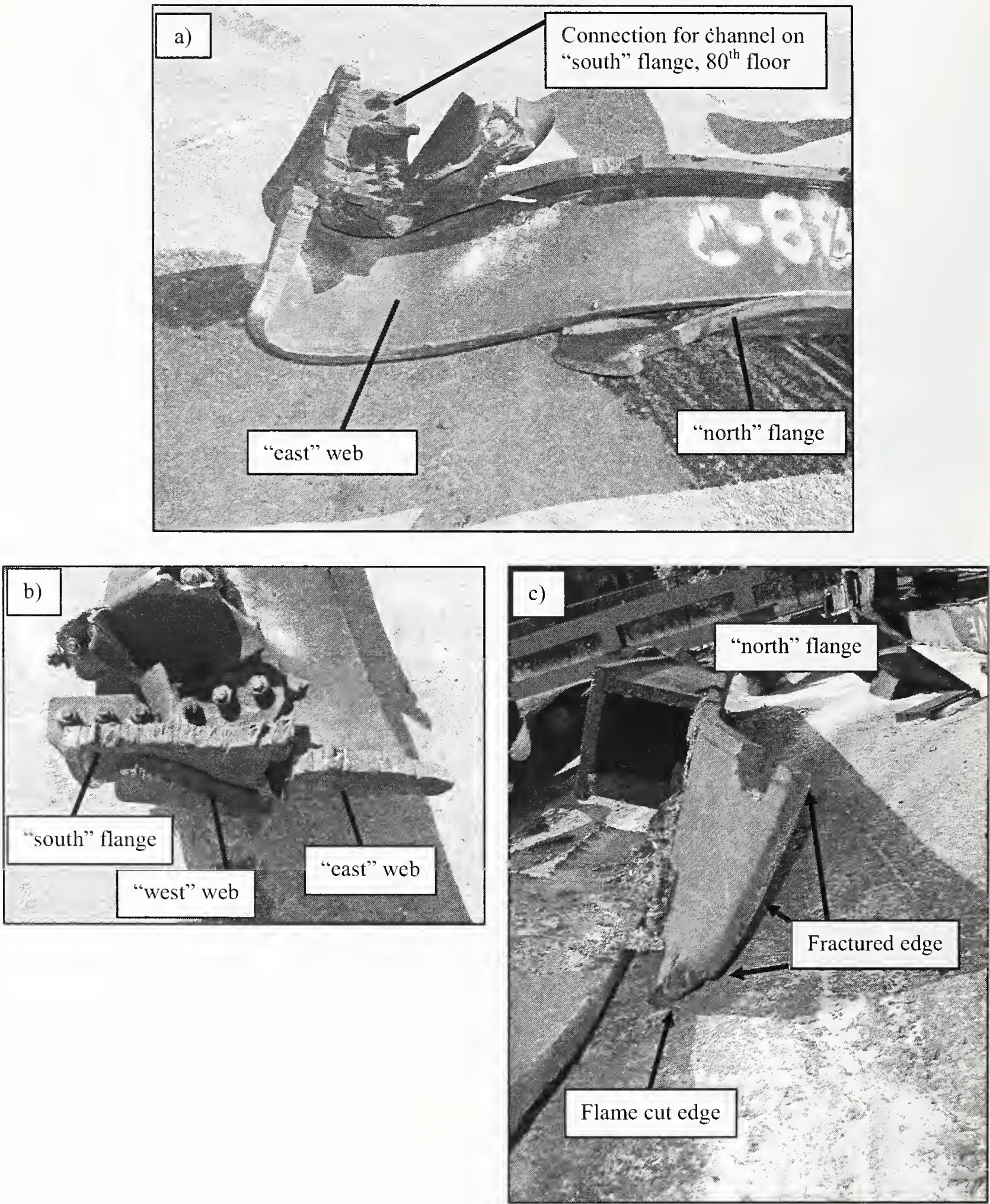

Source: NIST.

Figure 6-32. Damage associated with core column C-88b (801B: 77-80). a) Overall view of failed end, b) bottoms of "south" flange and both webs bent towards the east just below the 80th floor level, ends were flame cut, and c) "north" flange bent towards the north, majority of plate was fractured with some flame cutting. 
flange had a less significant bend toward the north, with approximately 80 perecnt of the failed cnd of the plate as a fracture. There was no visible nccking of the platc in the arca of failure, with the remaining portion of the plate having been flame cut during the rccovcry cffort. This flange was fracturcd roughly $2 \mathrm{ft}$ below the splice in the 80th floor lcvel. The fracture surfaces wcre too corroded for analysis. It was believed that the damagc of the south flange and the two webs occurred during collapse of the building as the direction of bending was not consistent with the travel of the airplane. Howcver, the damage to the north flange may have been a rcsult of impact damagc, as the scverity and location of the platc failurc was different from the other thrce platcs of the column, and the dircetion of the bend was consistent with the travel of the airplane. The baseline analysis of the damage model indicatcd that this corc column was not damaged as a result of the impact (NIST NCSTAR 1-2). Howcver, another analysis with paramctcrs sct to increase the amount of damagc indicated that impact damage was sustaincd. Corc column C-88a did not sustain impact damage as (1) the damage (81st floor lcvel) was above the floors of impact in this region (79th floor lcvel), (2) the columns were bent downward indicating ovcrloading of the column from above, and (3) the bending direction of the plates was opposite to the direction of the travcl of the planc. This is also consistent with the modeling results (NIST NCSTAR 1-2).

Aside from the three columns discusscd above, only one other corc column was recovered from within the fire region. Sample HH from WTC 1, Fig. 6-33, was a $42 \mathrm{ksi}$ wide-flange positioned near the middle of the second row of core columns along the north facc. The bottom half of the column was recovered (approximately $16 \mathrm{ft}$ ). The location of the column was such that damage could not have occurred during the impact. This was corroborated by the modeling results that indicated the core column was not hit during the impact (NIST NCSTAR 1-2). The failure modc of each end was different (Fig. 6-33a). Fracture of the plates used in the bolted connection occurred at the lower portion of the column (98th floor region), while the upper portion was torn through the material (100th floor region). Additionally, the sample was nearly bent in half (99th floor region), with completc fracture of one flange. Figure 6-33b shows that the flanges have become separated from the web in the region of the bcnd.

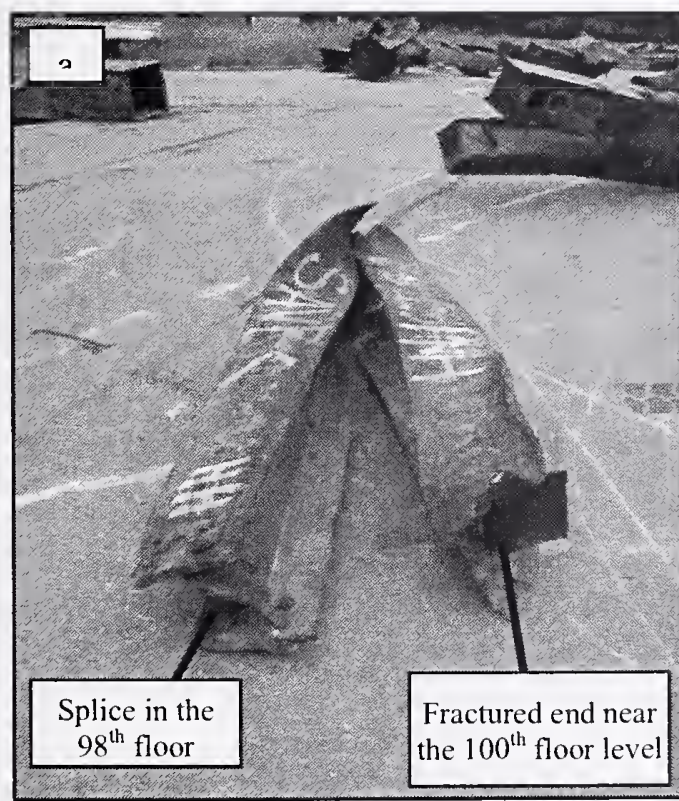

Source: NIST.

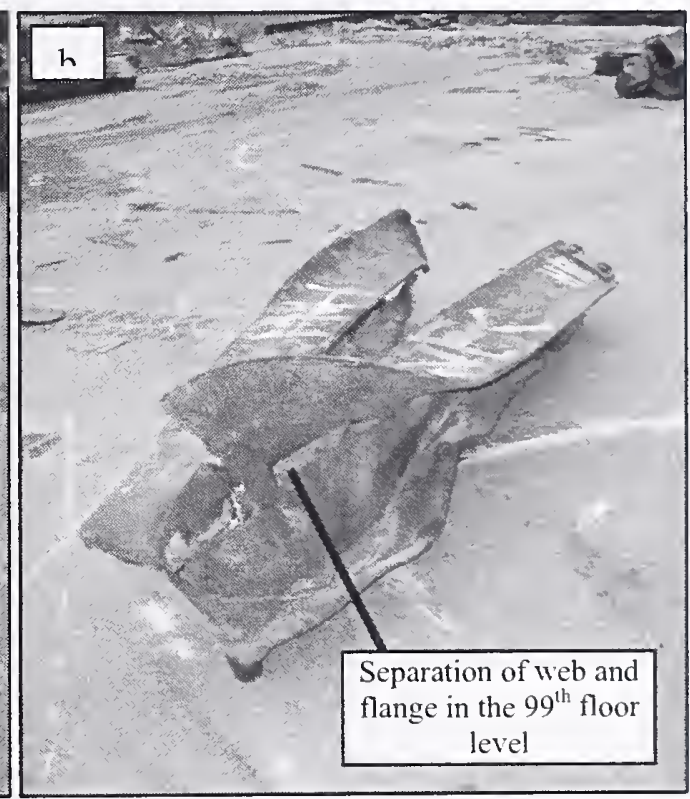

Separation of web and level

Figure 6-33. Core column HH (605A: 98-101). a) Fracture at both ends and b) separation between flange and web in the 99th floor region. 


\subsubsection{Core Channels and Truss Seats}

An analysis was conducted to evaluate the failure modes of the recovered channel material and the condition of the core truss seats. Of the 24 channels used to support the floor trusses, half failed at both ends within the channel itself, Fig. 6-34a, while the others failed at one or both of the end connectors, Fig. 6-34b. Twenty-one pieces of channel had seats or remnants of seats attached. Over 90 percent of the seats (31 total) were still intact with the majority of these somewhat deformed. Only two seats had been ripped completely from the channel at the welded joint between the seat and the channel, as shown in Fig. 6-34c. Half of the retained seats were observed to have both bolt holes still intact, while the other half had at least one bolt hole ripped out.
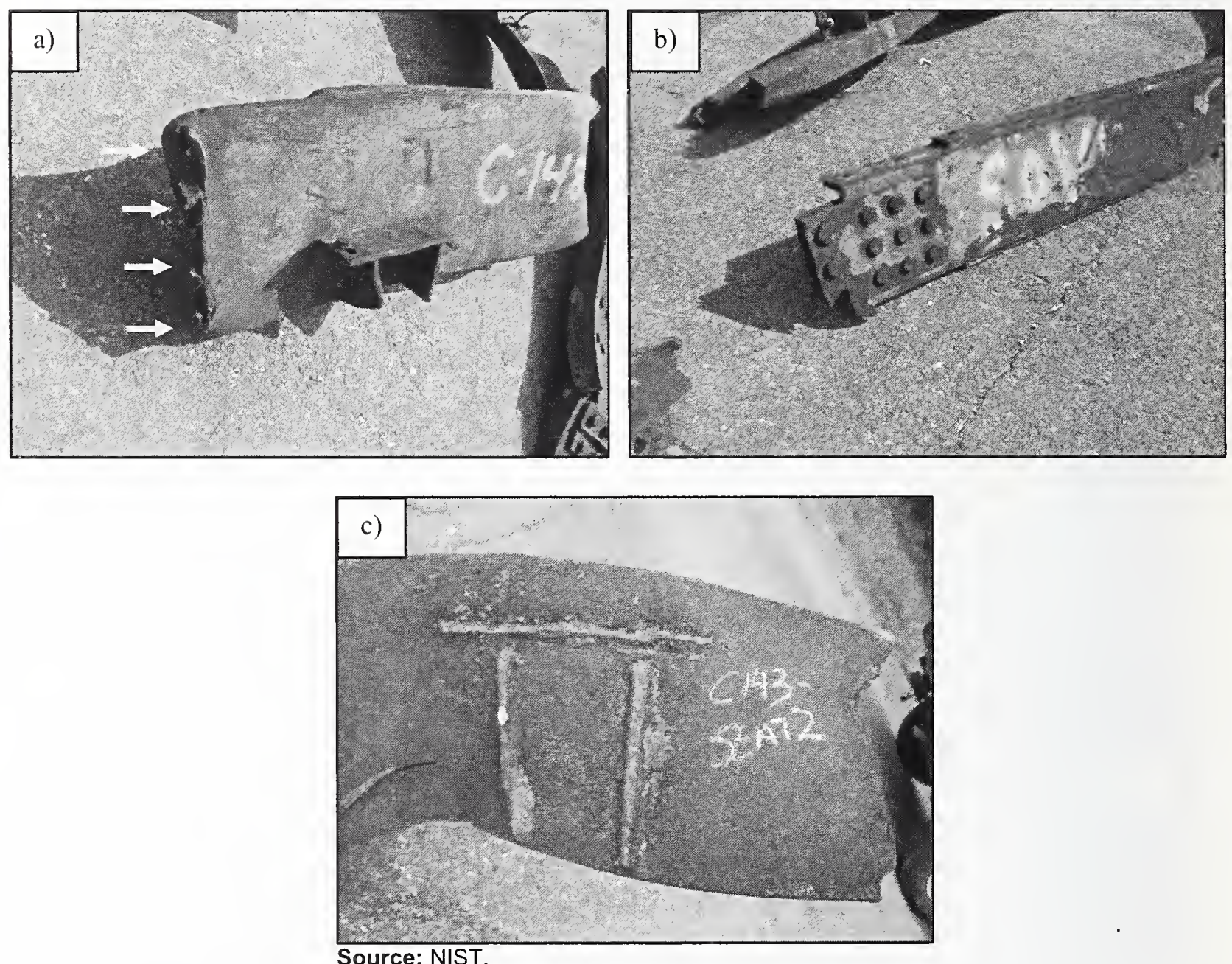

Figure 6-34. Failure modes of core channels. a) Fracture through channel as indicated by arrows, b) failure associated with end connector, and c) seat ripped off at welded connection to channel. 


\section{5 PHYSICAL DAMAGE OF FLOOR TRUSS MATERIAL}

A damage survey was conducted of the floor truss material to identify and inventory the various failure modes. A full discussion of these results can be found in NIST NCSTAR 1-3C.

Samples received at NIST were cithcr small sections (less than $3 \mathrm{ft}$ to $4 \mathrm{ft}$ in length) of chord and rod material (Fig. 6-35a) or large, entangled masses in the form secn in Fig. 6-35b. According to Structural Engineers Association of New York (SEAoNY) volunteer members involved in the recovery effort, it was necessary to "ball up" any truss pieccs of significant size to facilitate removal from the WTC sitc and subsequent handling in the recovery yards. This was neccssary since the primary and bridging trusses for a given floor were welded together into huge grids. During the collapse, these lightweight floor scctions were severely damaged and could not be casily removed. Thus, it is unknown when specific damage features occurred. Further, it is likely that sections of multiple trusses werc "ballcd" togcther and labelcd as a single unit rather than that NIST labeled samples consisting of just one pre-fabricatcd truss unit.
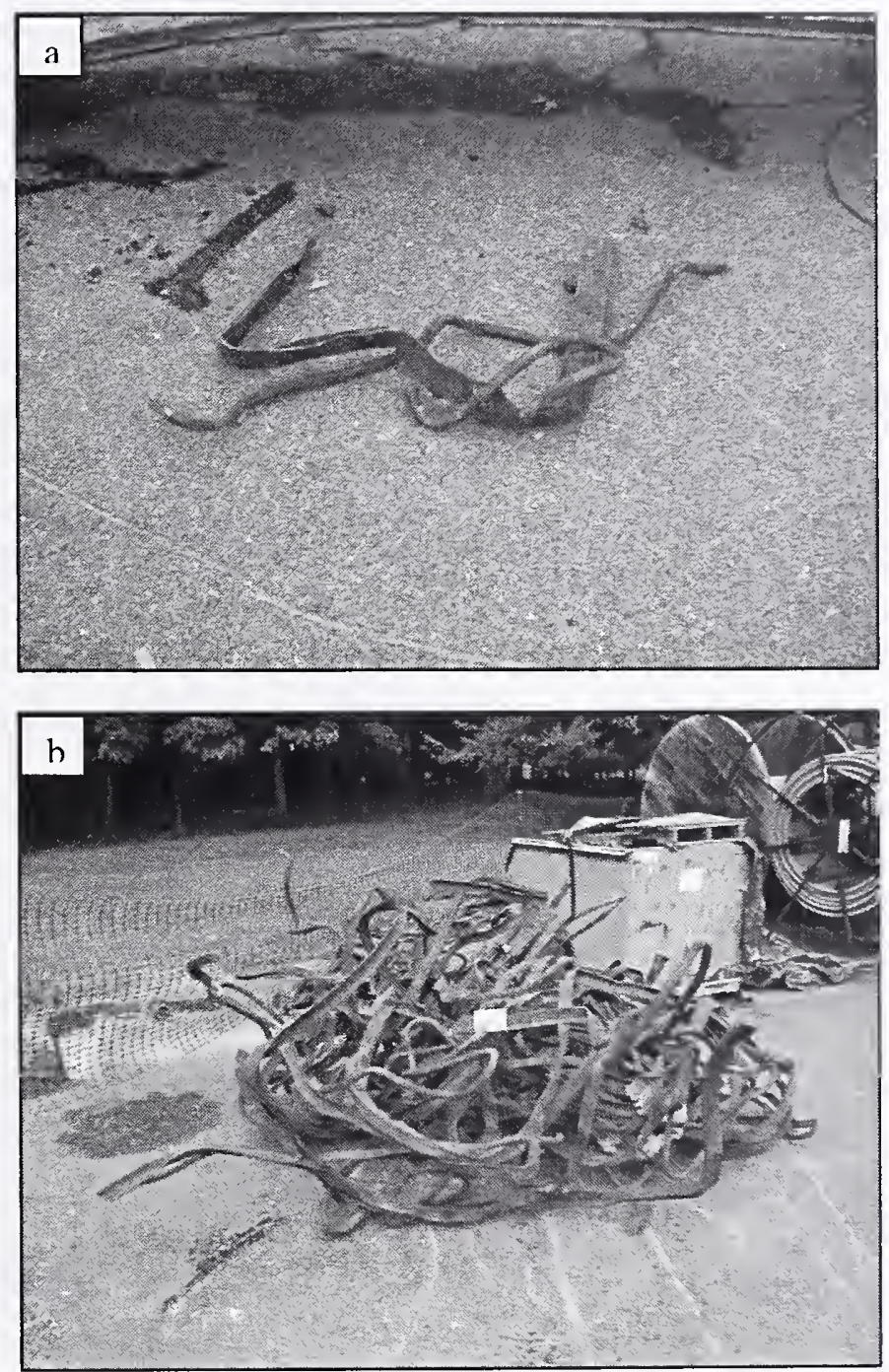

Source: NIST.

Figure 6-35. Examples of recovered floor truss material. a) Small sections of rod and chord (sample C-53) and b) "balled-up" sections of rod and chord (C-137f). 
Attempts were made to identify the as-built location of the truss material, but unlike the other major structural elements, identifying marks could not be found on the trusses. Difficulty was also encountered in trying to measure the length of the truss members to determine if they were of the $35 \mathrm{ft}$ or $60 \mathrm{ft}$ variety. It appears that no whole length sections were recovered. A large majority of the compressive resistance welds between the chords and rods were observed to have failed. This was evident from the large amount of chord material recovered without rods attached and vice versa. It is unknown when these failures occurred or what caused them.

\subsection{FIRE EXPOSURE OF THE STRUCTURAL ELEMENTS}

Examination of the structural steel components for indications of fire damage is important to provide an indication of the location and intensity of the pre-collapse fires in the towers, as well as the effect of the fires on mechanical properties of the structural steel. This portion of the analysis attempts to (1) determine the temperature excursions experienced by the steel components, (2) determine when the excursion occurred (pre- or post-collapse), (3) determine if pre-collapse fires significantly affected the mechanical properties of the structural elements such that the structural integrity (load bearing capabilities) of the component may have bcen compromised, and (4) provide this information for input/validation of the fire and thcrmal models of the reconstruction of thermal and tenability environment (NIST NCSTAR 1-5). Analytical techniques used to carry out these tasks involved assessment of the condition of the primer paint, microstructure, chemistry, and hardness of the steel. A full discussion of these results can be found in Chapter 6 of NIST NCSTAR 1-3C.

\subsubsection{Visual Inspection of Recovered Structural Components}

NIST has developed a novel approach to evaluating the primer paint on the structural components for evidence of exposure to high-temperature excursions (see Appendix D of NIST NCSTAR 1-3C). This method was found to be relatively easy to implement and robust enough to examine an entire component in the field. Calibration tests in the laboratory showed that, although there was little or no change in color, the primer paint used on the WTC steels that reached temperatures over $250{ }^{\circ} \mathrm{C}$ cracked (similar to a "mud cracking" pattern) from the difference in thermal expansion between the paint and the steel. Since deformation and environmental effects can also cause mud-cracking, the absence of mud-cracking indicates the steel has not exceeded $250{ }^{\circ} \mathrm{C}$, but the prescnce of mud cracks cannot be assumed to be caused by high temperature.

Visual inspection for the fire effects on recovered steel was conducted solely on the perimeter panels and core columns, as these were the only structural elements that had known as-built locations. Twenty-one pancls were selected with numerous locations on the inner webs, flanges, spandrels, and floor truss connectors for each floor lcvel analyzed, providing that sufficient paint was available for the analysis. Core columns C-80 and HH from WTC 1 wcre examined while C-88a and C-88b were tested from WTC 2; these columns resided within the fire floors for their respective buildings. The entire length of each core column was examined, and evaluations of the primer paint were made when sufficient paint was available for inspection.

Over 170 areas associated with the 21 exterior panels were analyzed, and the results may be found in Appendix E of NIST NCSTAR 1-3C. These 21 panels represent only 3 percent of the panels on floors 
involved with fire and cannot be considered representative of other columns on these floors. Only threc locations showed evidence of paint mud cracking:

1. Panel K-1, WTC 1, column 210, flange and inner web of 98th floor region. Prior to the collapse of WTC 1, the panel was observed to have expcricnced varying degrees of firc exposure for a minimum of 31 cumulative minutes in this area. A unique featurc of this pancl is that the upper portion of the column was crushed whilc generally maintaining concentric axial alignment with the lower portion of the column, Fig. 6--36. This suggests that deformation occurred at the onset of collapse, whilc the lower portion of the column was still constrained due to the bolted splice (cndplates).

2. Panel K-2, WTC 1, column 236, 93rd floor spandrcl. This area was obscrved to have firc exposure for nine cumulative minutes prior to collapse, Fig. 6-13. A positive reading was made directly below the truss seat while above the seat in the same location a negative result was obtained, Fig. 6-37. This suggests that the concrete floor may have shielded the upper portion of the column from the high-tempcraturc exposure experienced by the lower portion.

3. Panel N-8, WTC 1, column 143, seat and standoff plates of the 99th floor. This seat (Fig. 6-38) was exposed to fire for a minimum of 18 cumulative minutes before collapse. Mud cracking was not observed on the spandrcl plate to which the seat was welded.

\subsubsection{Core Columns Exposed to Fire}

Four of the core columns with known as-built locations were examined for mud cracking of the paint. For columns C-88a and C-88b, sufficient paint for analysis was not available. For columns HH and C-80, few areas of paint were observed (thrce to five spots per column) with no indication of temperatures over $250{ }^{\circ} \mathrm{C}$. Note that these core columns represent less than 1 percent of the core columns on floors involved with fire and cannot be considered representative of any other core columns.

\subsubsection{Metallographic Analysis of Elements Exposed to Fire}

Some aspects of the thermo-mechanical history of a structural steel element may be revealed through a careful assessment of the component's microstructure. Identification of phases, whether stable or metastable, and their characteristics (e.g., size, morphology, distribution) can help lead to an understanding of the possible rolling conditions and/or cooling rates used during fabrication. These factors are directly related to the room temperature mechanical properties of the component. Likewise, high-temperature excursions due to fire can also alter the microstructure and the mechanical properties. Therefore, if knowledge of the as-fabricated microstructure is available, then a review of the "affected" microstructure may give an indication of the level of elevated temperature exposure while in service. Thus, an assessment was made to determine if information could be compiled on the extent and effect of fire exposure through changes in the microstructure. When appropriate, chemical analysis and hardness evaluations were used to supplement the results. A full discussion of these results can be found in NIST NCSTAR 1-3C.

Samples for analysis were chosen based upon the panel exposure to pre-collapse fires. These included floor truss connectors (seats) and the lower portion of spandrels where external flaming was observed in 
the window directly beneath the location of sample removal. The microstructural results were compared with the paint mapping analysis, to confirm the apparent dissonance between the results of the paint mapping study and those from the pre-collapse fire exposure results reported in Sec. 1.2.5.

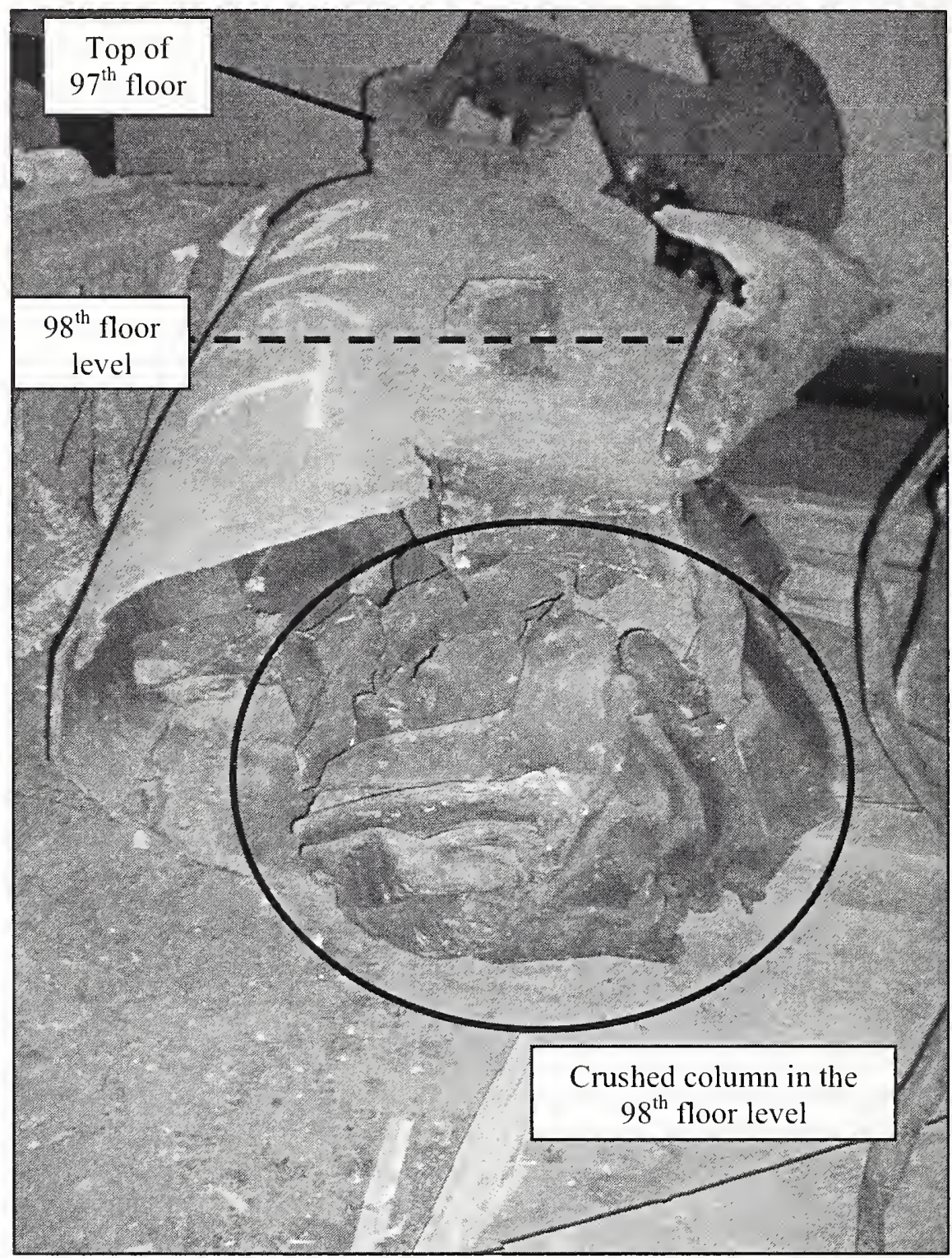

Source: NIST.

Figure 6-36. Crushed portion of column 210 in the area of the 98th floor (from sample K-1, A209: 97-100). Paint had mud cracking characteristic in this region. 


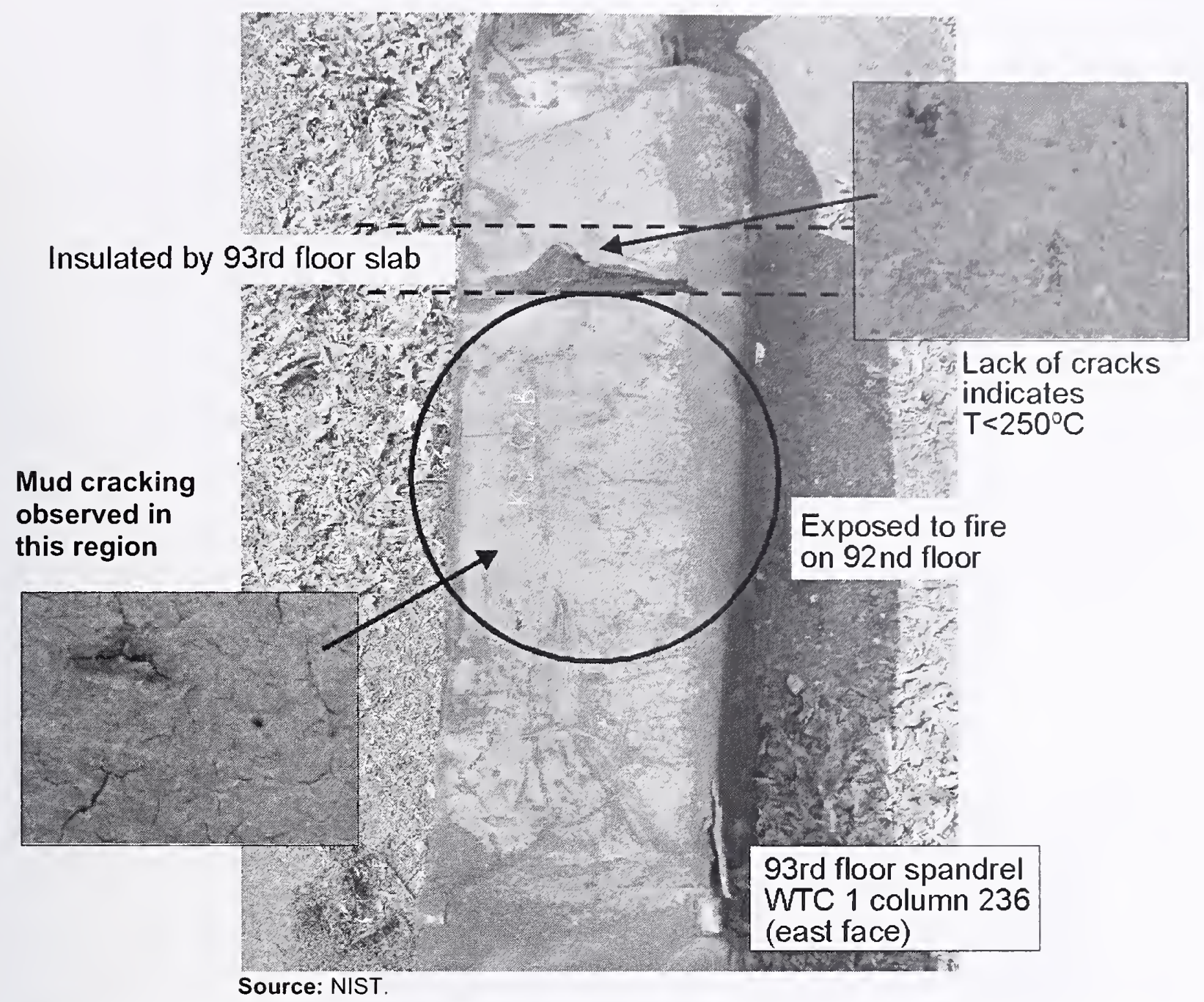

Figure 6-37. Spandrel at the 93rd floor of column 236 from sample K-2 (A236: 92-95). Paint mud cracking was found below the 93rd floor line, no evidence of paint mud cracking was found above floor line. 

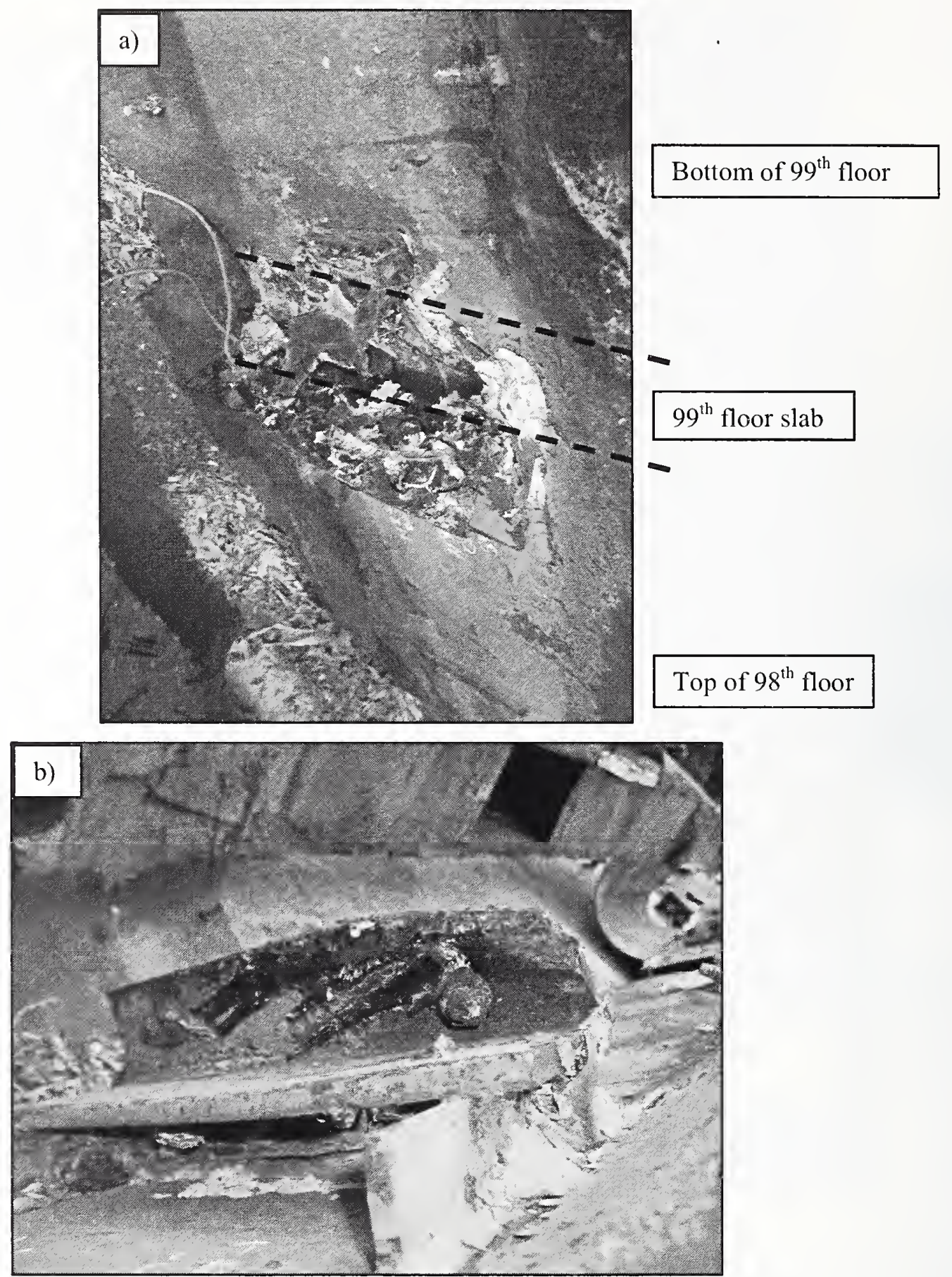

Source: NIST.

Figure 6-38. Truss seat of the 99th floor on column 143 of sample N-8 (A142: 97-100). a) Top view showing the re-solidified black plastic with embedded papers, most likely a binder of some type and b) bottom view showing the drip pattern. It was unknown when the high-temperature excursion may have occurred. 
The spandrcl stecls identificd as having bcen exposed to firc prior to the collapsc of the building showed no microstructural evidence of change. Similar results indicated that threc of the four scats obscrved to bc exposed to severe pre-collapse firc conditions did not experience significant microstructural changes as a result of the exposurc. However, the seat with the mcltcd binder (Fig. 6-38) did show signs of microstructural alteration as a result of elevated tempcraturc exposure, though it was unknown when this exposure occurred. Finally, in the several columns with known pre-collapse firc cxposure, mctallographic analysis provided no conclusive evidence that the stcel cxceeded $625^{\circ} \mathrm{C}$, based on calibrations in furnacc exposurc studies of WTC stecl reported in NIST NCSTAR 1-3E.

\subsection{COMMENTS CONCERNING CONTRACT TO WISS, JANNEY, ELSTNER}

Consulting engineers from Wiss, Janney, Elstner Associates, Inc. (WJE) provided NIST investigators with an independent evaluation of the stcel recovered from the WTC sitc. This report, concentrating on failure mode observations and indications of fire exposure to the structural stcel, is appended to NIST NCSTAR 1-3C. The conclusions drawn by the WJE team were in general agrecment with the findings of the NIST Investigation team, with a few specific examples of disagrcement that are discusscd in NIST NCSTAR 1-3C in light of additional forensic evidence developed by NIST and not available to the WJE team at the time of their examinations.

\section{8 $\quad$ FINDINGS}

The following findings have been made bascd on pre-collapse photographic analysis and observations of the recovered steel. It should be noted that observations were made of a small fraction of the structural steel in the towers and that pieces were selected focusing on apparent fire and impact damage.

\subsubsection{Structural Damage of Exterior Panel Sections}

Observations of pre-collapse photographs and the recovered panels from the impact zone indicated that two of the four recovcred impact-damaged panels (M-2 and M-30) appear to be in a condition similar to their condition just prior to building collapse. Some damage can be attributed to the events during and after collapse, but the general shape/appearance of the recovered pieces agree with the damage photographs.

In general, severing of the perimeter columns occurred at an internal stiffener plate or diaphragm plate (associated with the spandrel connection to column).

There was a greater tendency for perimcter columns impacted by the airplane to have experienced base plate fracture near welds than for those outside of the impact zone.

There was no evidence to indicate that the type of joining method, materials, or welding procedures used to fabricate the perimeter columns was improper. The welds appeared to perform as intended during service.

With the exception of the mechanical floors, the major failure mechanism for perimeter panel column splices was fracture of the bolts. At mechanical floors, where splices were welded in addition to being bolted, the majority of the splices did not fail. 
Spandrel connections on cxterior panels at or above the impact zone were more likely than those below this region to experience bolt hole tear out as a failure mode. For those exterior panels below the impact zone, there was a higher propensity for the spandrels to be ripped off from the panels.

There did not appear to be any difference in failure mode for the spandrel connections whether the exterior panels were exposed to fire or not.

\subsubsection{Structural Damage of Core Columns}

Failure of core columns was a result of both splice connection failures and fracture of the columns themselves.

Core column C-88b (801B: 77-80) may have sustained damage as a result of the airplane impact; however, the welded splice to the column above survived intact.

\subsubsection{Structural Damage of Floor Trusses and Seats}

The majority of perimeter panel floor truss connectors (perimeter seats) below the impact floors were either missing or bent downward. Above this level, the failure modes were randomly distributed. This trend was observed for both towers.

Failure of perimetcr panel floor truss connectors (truss seats) typically occurred in the component that had the lowest cross-sectional area with respect to the high loading forces experienced during the collapse of the buildings. Fracture of the standoff plates was typical. There was no evidence to indicate that type of joining method, materials, or wclding procedures used to fabricate the truss seats was improper. The truss seats and associated welds appeared to have performed as intended during service.

Failure of the connection between the floor truss and the perimeter panel floor truss connectors was typically a result of tab plate and bolt failure.

Of the 31 core floor truss connectors (core seats) recovered, 90 percent were still intact, though extensive damage may have occurred. Only two were observed to have been completely tom from the channel. (This distribution may have resulted from the selection process at the salvage yards).

In the floor trusses, failure of a large majority of the electric resistance welds at the web-to-chord connections was observed.

\subsubsection{Damage to Sprayed Fire-Resistive Material}

Pre-collapse photographs indicated that, as expected, fire-proofing was removed from pieces struck by the incoming aircraft or debris exiting the far side of the buildings. In addition, the impact caused fireproofing and aluminum facade panels to spall off many perimeter columns which were not directly struck nor severed, but apparently suffered strong accelerations and forces otherwise transmitted through the structure. This indirect damage to the SFRM was observed on the north and east faces of WTC 2.

A coating on the SFRM prevented the loss of the SFRM in some locations on the perimeter columns. This coating appears as a band of white features on the SFRM wherever two aluminum panels met on the 
exterior columns of the buildings, becoming visible when the panels were dislodged. This may be a coating applied to protect the SFRM from moisture infiltration at the aluminum panel joints, acting to preserve the SFRM even when the SFRM was knocked off both above and below those locations.

\subsubsection{Fire Exposure of Exterior Panel Sections}

Portions of 16 recovercd exterior panels were observed to have been exposed to fire prior to the collapse of WTC 1. This was determined using video and photographic images. None of the nine panels from within the fire floors of WTC 2 were observed to have been directly exposed to fire.

It is difficult or impossible to determine if high-tempcrature exposure occurred prior to or after the collapse. Of the more than 170 areas cxamined on 21 exterior panels, only three locations had mudcracking of the paint, indicating that the steel may have reached temperatures in excess of $250{ }^{\circ} \mathrm{C}$. The 21 panels represent only 3 percent of all panels on the fire floors, however, and cannot be considered representative of other columns on these floors.

Based on microstructural analysis of the recovered structural steel, there was no evidence indicating that the pre-collapse fires were severe enough to affect the steel microstructure of these pieces. Based upon this evidence, it is believed that no steel was recovered which experienced temperature excursions above $600{ }^{\circ} \mathrm{C}$ for any significant length of time as a result of the pre-collapse fircs.

Perimeter columns exposed to fire had a great tendency for local buckling of the inner web; a similar correlation did not exist for weld failure.

\subsubsection{Fire Exposure of Core Columns}

Two of the core columns with as-built locations in the fire-affected floors were examined for paint cracking. The few areas with sufficient paint for analysis did not show mud cracking patterns, indicating the columns did not exceed $250^{\circ} \mathrm{C}$. (It must be recognized that the examined locations represent less than one percent of the core columns located in the fire-exposed region, and thus these temperatures cannot be considered representative of general conditions in the core).

\subsubsection{Time-Dependent Deformation of Perimeter Walls due to Fire and Load Redistribution}

Images of WTC 1 showed gross deformations of the south exterior wall prior to final collapse. Images of the south face of the tower taken approximately 5 min prior to collapse showed inward bowing of the exterior columns, reaching an observable maximum of about 55 in. near column 316 on the 96 th floor. The inward deflection appears to extend over the entire south face of the building at this time, and is visible vertically between the 94 th and 100 th floors. Photographs taken approximately 30 min prior to this time do not show any inward bowing of the south face of WTC 1.

Approximately 18 min after the impact of the aircraft, the east face of WTC 2 exhibited inward bowing of up to $10 \mathrm{in}$. in the region of the 79 th to 83 rd floors. This inward bowing increased to $20 \mathrm{in}$. at a time $5 \mathrm{~min}$. before collapse of the tower. 
Hanging floor slabs at the 82nd and 83rd floors were visible in window openings on the east and north faces, respectively, of WTC 2 and the positions of these slabs changed over time. This suggests a progression of failure of certain parts of the flooring in this area of the tower.

At the moment of collapse of WTC 2, the top portion of the building was found to have moved to the west as it tilted to the southeast. During this tilting, a complex kink developed at the southeast corner of the top of the building, in the region of the 106th floor. In addition, the portion of the building above the aircraft impact site twisted slightly clockwise (as viewed from above) as the collapse progressed.

\subsubsection{Other}

In general, the observations made by an outside contractor concerning possible local failure mechanisms of the WTC steel were in agreement with those found by NIST. 


\section{Chapter 7 \\ Mechanical Properties of Structural Steels}

\section{$7.1 \quad$ INTRODUCTION}

National Institute of Standards and Technology (NIST) had three goals in charactcrizing the mechanical properties of the steels, bolts, and wclds. The first was to compare the measured properties of the stccls with the requirements of the specifications that they werc purchased under. The second was to determinc whether their properties were consistent with the properties and quality of structural stcel from the World Trade Center (WTC) construction era. The third was to determine the constitutive bchavior for input into finite element models of the response of the building components to the aircraft impact and to the high temperatures that the subsequent fires produced.

In support of these three goals, the steel was characterized in five main areas:

1. Elastic properties as a function of temperature,

2. Room temperature tensile stress-strain behavior measurcd using conventional tensile tests,

3. Impact properties measured using Charpy tests,

4. High-strain rate stress-strain behavior measured using conventional, high-rate tensile tests as well as compressive Kolsky bar tests, and

5. Elevated-temperature stress-strain behavior of perimeter, core, and truss steels, as well as creep behavior of truss steels.

\section{$7.2 \quad$ ELASTIC MODULUS}

Figure 7-1 shows the dependence of elastic modulus, $E$, as a function of temperature along with other determinations reported in the literature. The NIST data were determined from three different perimeter column steels using a dynamic mechanical analyzer in flexure at a frequency of $1 \mathrm{~Hz}$. The maximum deviation of the experimental data from the fit to the modulus in Fig. 7-1 is 1.5 percent. The enormous scatter in the literature data arises primarily from the test methods employed. The literature values greater than the NIST determination generally come from ultrasonic measurements, which are inappropriate for modeling the building, while those less than the NIST value generally come from the loading portions of tensile tests. At high temperatures, such values include significant plastic deformation and are thus not appropriate for elastic calculations. The modulus curve in Fig. 7-1 is a third-order polynomial fit to the data for $0{ }^{\circ} \mathrm{C}<T<600{ }^{\circ} \mathrm{C}$ and extrapolated to $723{ }^{\circ} \mathrm{C}$.

Other elastic properties needed for modeling (Poisson's ratio and shear modulus) have also been calculated as a function of temperature and are reported in NIST NCSTAR 1-3D. 


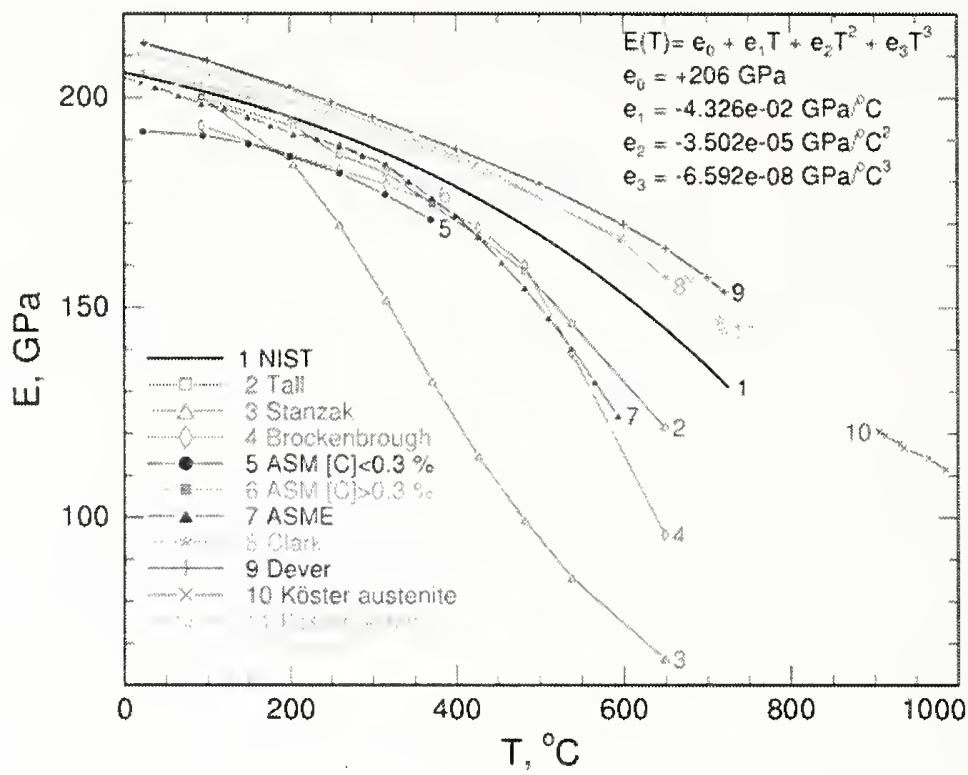

Figure 7-1. Elastic modulus as a function of temperature determined by NIST compared with literature data for structural steel.

\subsection{ROOM TEMPERATURE TENSILE PROPERTIES}

\subsubsection{Measured Tensile Properties}

To characterize the room temperature stress-strain bchavior of the steels in the fire and impact zones of the buildings, NIST tested specimens from 52 different steel plates and shapcs: 31 from perimeter columns and spandrels, 11 from core columns, 5 from truss components, 3 from perimeter truss seats, and 2 from core truss seats. Tests generally followed the ASTM International (ASTM) E 8 protocol.

Figure 7-2 is an example set of room-temperature, stress-strain curves for a perimeter column spandrel plate from WTC 2. All test results are given in NIST NCSTAR 1-3D. Figures 7-3 and 7-4 graphically present measured yield strength as a function of specified minimum yield strength for perimeter and core columns.

\subsubsection{Measured Properties and Specifications}

Assessing the mcasured tensile properties in relation to the requirements of the various specifications was not straightforward in many cases. NIST was able to quantify the mechanical properties and chemical composition of the steel pieces in their recovered state. These "product" tension tests on representative specimens of the 52 different recovered steels established their yield and tensile strengths and elongations to failure. Chcmical characterization established whether the composition of the recovered steel lay within the limits set by the various standards. 


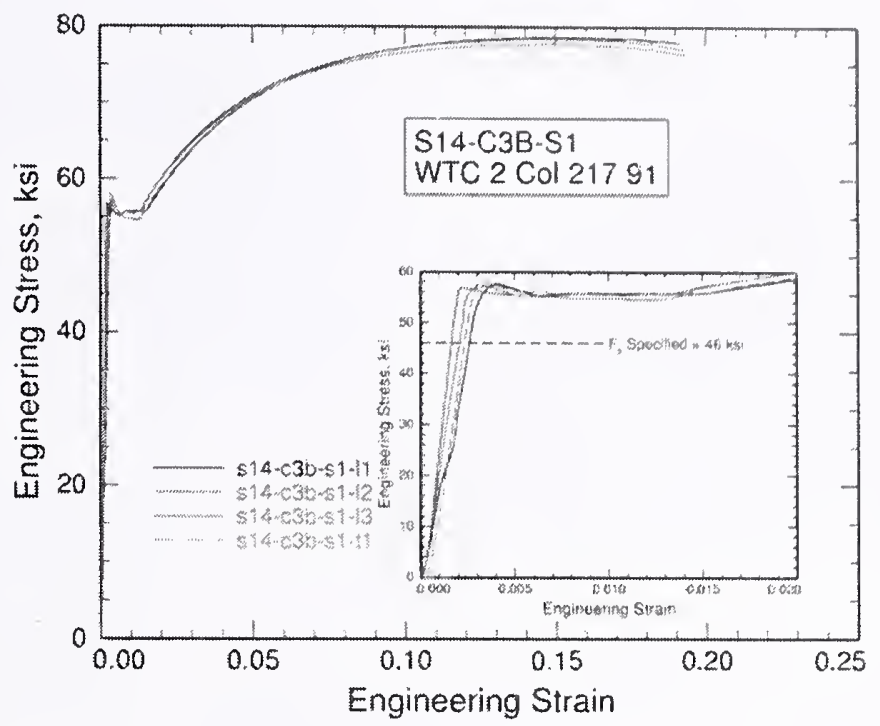

Figure 7-2. Examples of longitudinal $(11,12$, and 13$)$ and transverse (t1) room-temperature, stress-strain curves for a $F_{y}=46 \mathrm{ksi}$ perimeter column spandrel plate.

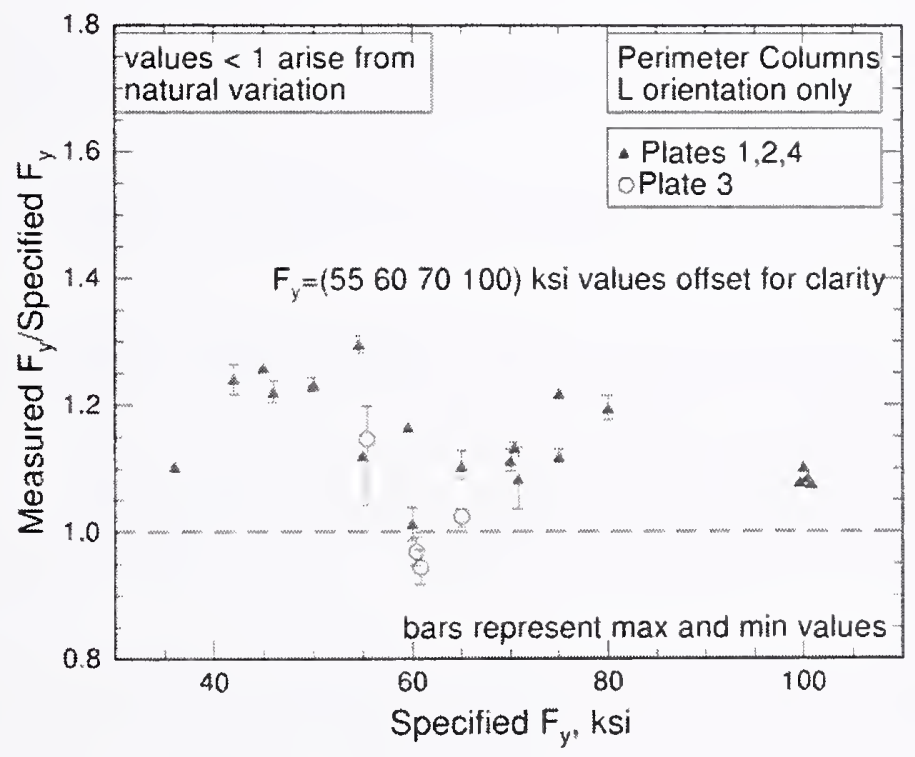

Figure 7-3. Ratio of measured yield strength or yield point to specified minimum yield point for WTC perimeter column steels. 


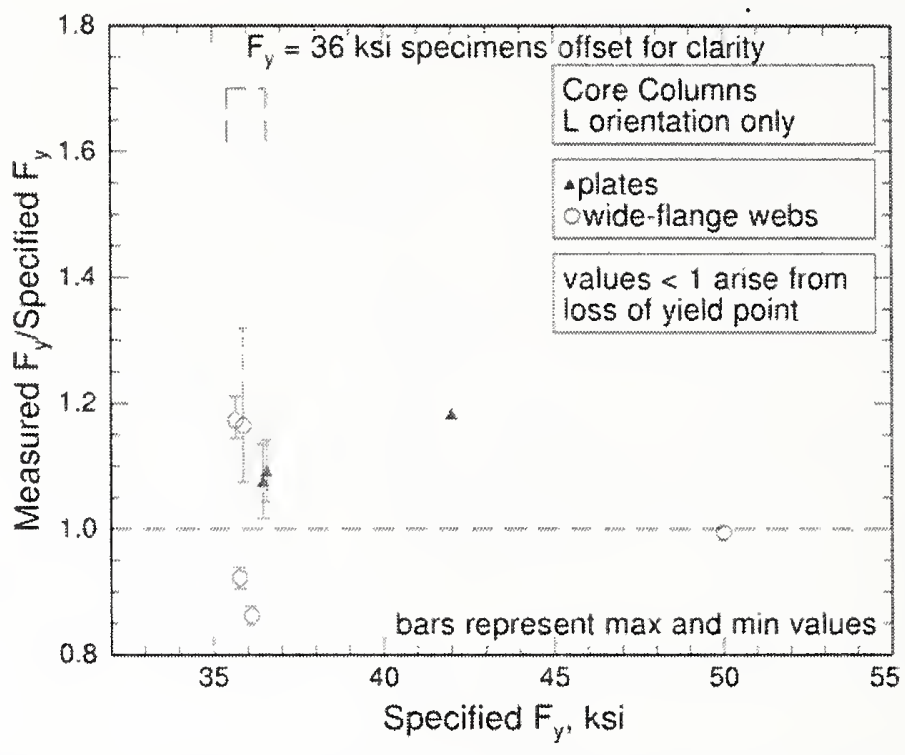

\section{Figure 7-4. Ratio of measured yield strength or yield point to specified minimum yield point for WTC core column steels.}

Four issues complicated the task of positively assessing the likelihood that the properties of the recovered steel were consistent with the requirements of the relevant specifications. The first was that the WTC steels could be supplied to many different, overlapping specifications. No documents exist that identify the ASTM specification for a given column. Only the specified minimum yield strength was known. Secondly, differences between the NIST test procedures and the mill test procedures that originally qualified the steel, including testing rates, specimen sizes, and test locations, could result in values for the NIST-measured yield strengths that were less than the requirements of the relevant specification. Thirdly, the natural variability of steel properties within a heat can cause some locations to have yield strengths that are lower than the minimum required by the relevant standard. Finally, even slight damage to the steel, caused by the collapse of the WTC towers or subsequent recovery efforts, could remove the yield point behavior in the tensile test. Most low- and medium-strength steels are qualified using the stress measured at the yield point, rather than the 0.2 percent offset yield strength. For standards that define the yield strength as the yield point, the absence of yield point behavior in a NIST-conducted test can lead to values of yield strength that are less than the minimum required by the specification.

The investigation made several findings regarding the quality of the recovered steel. The yield and tensile strength, Fig. 7-3, of the perimeter columns, with only a few exceptions, easily exceeded the strength requirements intended, typically by 10 percent to 15 percent. The number of slightly under-strength plates and the amount by which they fall short were consistent with expected values for the average strength and coefficient of variation of plate steels from the WTC era. The ratio of measured yield strength to specified yield strength, Fig. 7-3, was also consistent with literature estimates from the WTC era. The chemistries of the individual perimeter column steels, lay within the ranges specified in the relevant Yawata Steel proprietary compositions.

The NIST-measured yield strengths of several of the wide-flange shapes recovered from the core were less than specified in A 36, Fig. 7-4. It is likely that these low values arose from a combination of 
damage to the column and differenees between the protocol NIST used for determining yicld strength and the protocol under which the steels wcre originally qualified. Bccause these effects are testing artifaets, they do not indicate that the steel was of insufficient quality. The recovered core wide-flange columns were more heavily distorted than the core and pcrimeter box columns; in most eases, it was not possible to find undeformed seetions to test. Low strength steels, like the core wide-flange columns are qualified based on the yield point, or the maximum stress reached before permancnt deformation. After yielding, the stress drops immediately by as much as $5 \mathrm{ksi}$. Small strains ean remove this yield point behavior entirely, and result in yicld strengths that are less than the specified minimums. In each case where tensile test specimens from the wide-flange columns did not exhibit a definite yicld point, the measured distortion of the column was sufficient to induce a strain that could remove that yicld point. A second confounding factor that could have further reduced the reported yicld strength arose because NIST tests employed a slightly lower testing rate than would have been uscd in the mill test. Because the strength of steel increases slightly with the testing rate, this difference could further rcduce the NIST-measured yield strength by several ksi.

The ratio of measured yield strength to specified yicld strength in Fig. 7-4 was also lower than some literature estimates from the WTC era. Those historieal estimates, however, were based on measurements of shapes with much smaller dimensions, in contrast to the massive wide-flange shapes in the core of the towers. Because of their size, the strengths of those massive shapes might be expected to exeed the specified minimums by less than those for the more heavily rolled, lighter shapes from the literature.

Many of the steels in the floor trusses were high-strength, low-alloy (HSLA) steels, with yield strengths above $50 \mathrm{ksi}$, even when they were specified to conform to the lower-strength A 36.

Recovered and tested bolts not only met the A 325 specification, but also were much stronger than expected based on reports from the contemporaneous (1960s) literature.

The welds in the perimeter and core columns and floor trusses had properties consistent with the intended specifications.

\subsubsection{Representative Steel Stress-Strain Curves}

To satisfy the third objective of the room temperature tensile testing program, NIST produced models of stress-strain curves for each of the grades of steel in the fire and impact zones of the towers, for a total of 29 different steels. The modeling groups associated with the investigation required complete stress-strain behavior, rather than just yield and tensile strengths and total elongations. Figure 7-5 shows examples of representative stress-strain behavior provided for the perimeter column steels. For the perimeter column and truss steels, the yield strengths were corrected for dynamic effects during testing and, where possible, experimental data were combined with surviving WTC mill test reports. Experimentally derived stressstrain curves, modeled using the Voce work-hardening law, were used to describe the plastic deformation of each steel. For the core columns, the yield strength was assumed to be the historical average from the literature of the WTC era, corrected for dynamic effects. Actual tests on WTC core column steels, modeled using Voce work-hardening, supplied the plastic behavior. For the A 325 bolts, NIST supplied load-displacement curves measured on recovered bolts. 


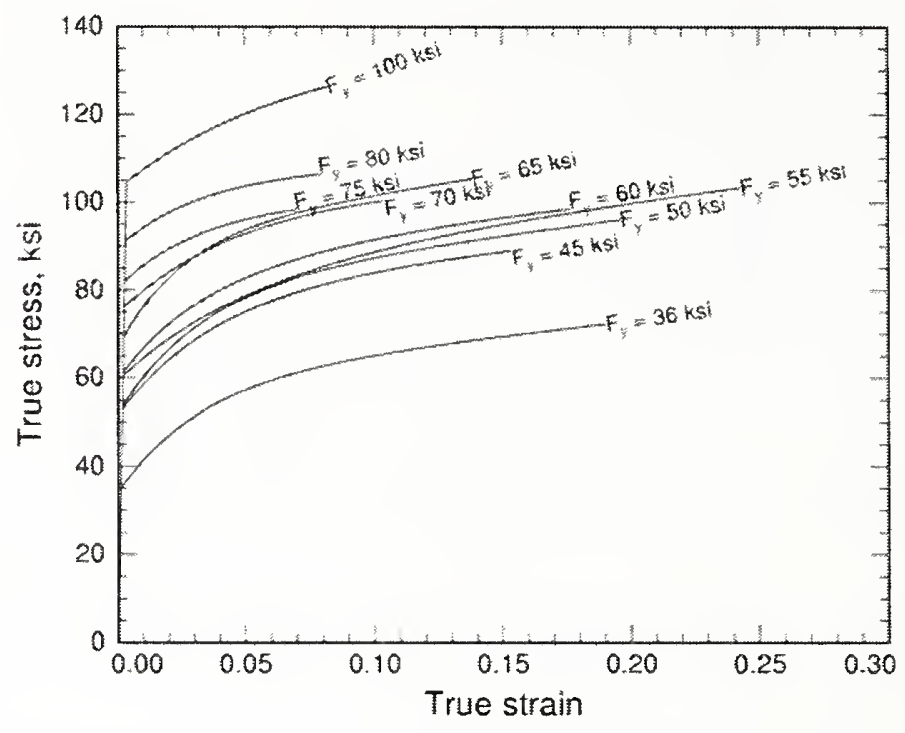

Figure 7-5. Examples of representative true-stress true-strain curves for perimeter column steels.

\subsection{HIGH-STRAIN RATE TESTS}

Because the strength of steel depends on the rate at which it is deformed, it is necessary to quantify the relation between stress and strain rate for the steels in the impact zone. Failing to properly account for the increased strength with deformation rate could lead to incorrect estimates of the internal damage to the buildings caused by the airplane impact.

In support of this goal, the investigation employed two different types of high-strain rate tests. Tests at rates in the range $50 \mathrm{~s}^{-1}<\dot{\varepsilon}<500 \mathrm{~s}^{-1}$, used a servohydraulic tensile test machine and special flat tensile specimens. Tests at higher rates employed a Kolsky bar test machine in which the test specimen is a cylinder loaded in compression.

The sensitivity of the flow stress to strain rate is expressed in a simple manner from which all other strain rate effect relations can be calculated. The strain rate sensitivity, $m$, is calculated from the slope of a $\log _{\mathrm{e}}(\sigma)-\log _{\mathrm{e}}(\dot{\mathcal{\varepsilon}})$ plot:

$$
\log _{e}\left(\frac{\sigma}{\sigma_{0}}\right)=m \log _{e}(\dot{\varepsilon})-m \log _{e}\left(\dot{\varepsilon}_{0}\right)
$$

where $\sigma_{0}=1 \mathrm{ksi}$, and the $\sigma$ in the numerator is either the yield or tensile strength.

Figure 7-6 compares the strain rate sensitivities for the WTC steels characterized to structural steels from other studies. The behavior of the WTC steels is entirely consistent with the literature data. The magnitudes of the strain rate sensitivities are similar and lie in the range $0.01<m<0.06$. The strain rate sensitivity also decreases with increasing yield strength. The total elongations, $E l_{l}$, of the WTC steels, not shown, are not a strong function of rate. The total elongation increased with rate in seven of the eight WTC steels characterized, but the increase was only 2 to 3 absolute percent. This behavior is similar to 
the behavior of structural steels reported in other studies. Kolsky bar testing demonstrated that the strength of the recovered A 325 bolts is insensitive to strain rate.
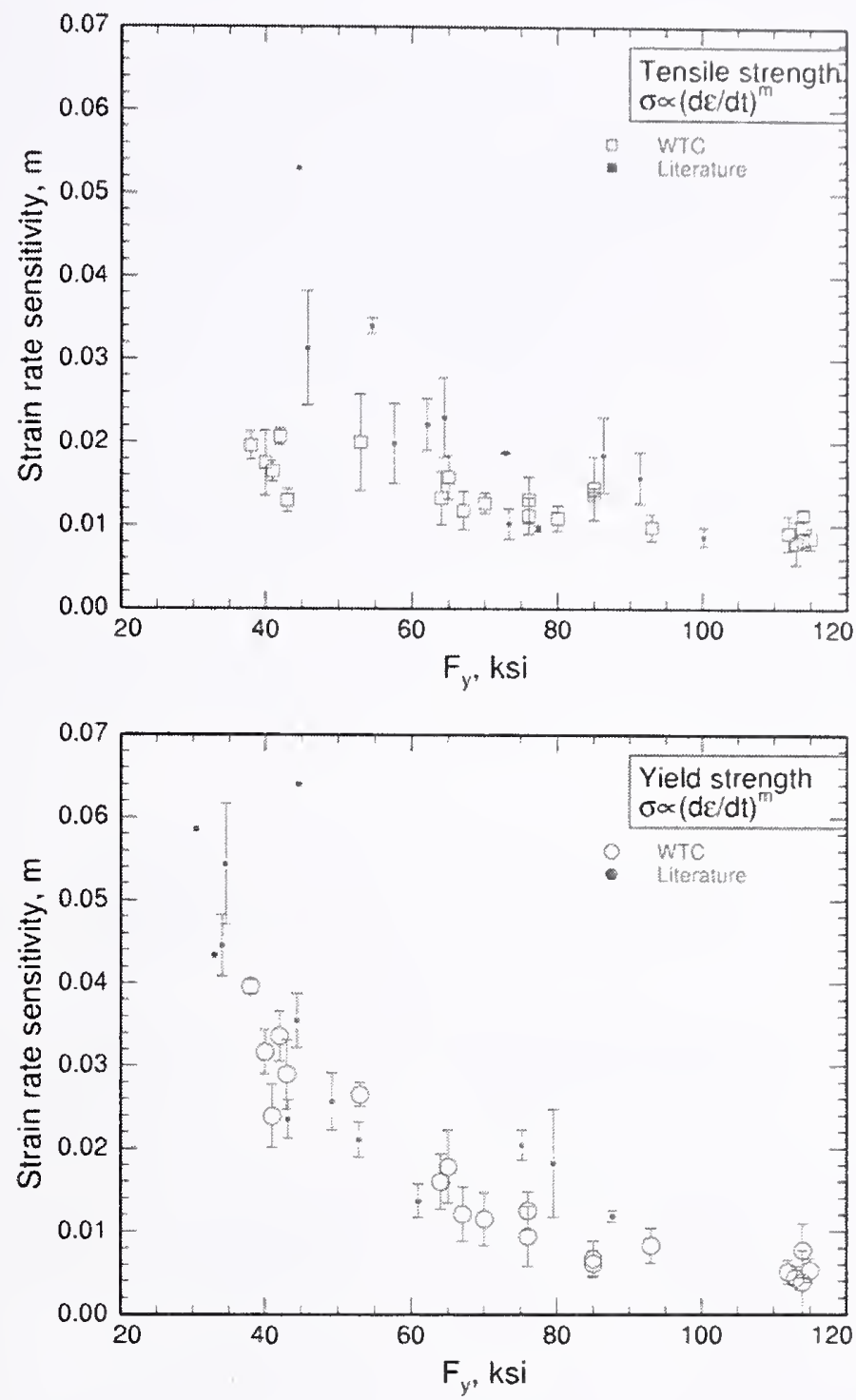

Figure 7-6. Strain rate sensitivity as a function of specified minimum yield strength for WTC steels.

\subsection{CHARPY TESTS}

The Charpy impact test is a type of dynamic fracture test that probes the ability of steels to absorb energy in the presence of notches before fracturing. As such, Charpy tests are particularly relevant to the airplane impact and complement the high-strain rate tests. In the Charpy test, the energy used to break a notched specimen is measured as a function of temperature. At the higher temperatures the absorbed energy is large and relatively constant, and forms what is called the "upper shelf." Failure on the upper 
shelf is ductile. At the lower temperatures the absorbed energy is small and again constant with temperature, and forms the lower shelf. Failure on the lower shelf is brittle.

Figure 7-7 summarizes the results of Charpy tests on perimeter and core column steels. All the perimeter column steels have large upper shelf energies and transition temperatures well below $0{ }^{\circ} \mathrm{F}$. The transition temperatures of the web of the wide-flange specimen, Fig. 7-7, and the truss rods and angles, not shown, are near room temperature, but they still possess adequate toughness for use as structural steels. The transition temperatures of the truss seat steels are above room temperature, and the absorbed energy of the steels even at room temperature is low, indicating a propensity for low-energy failure.
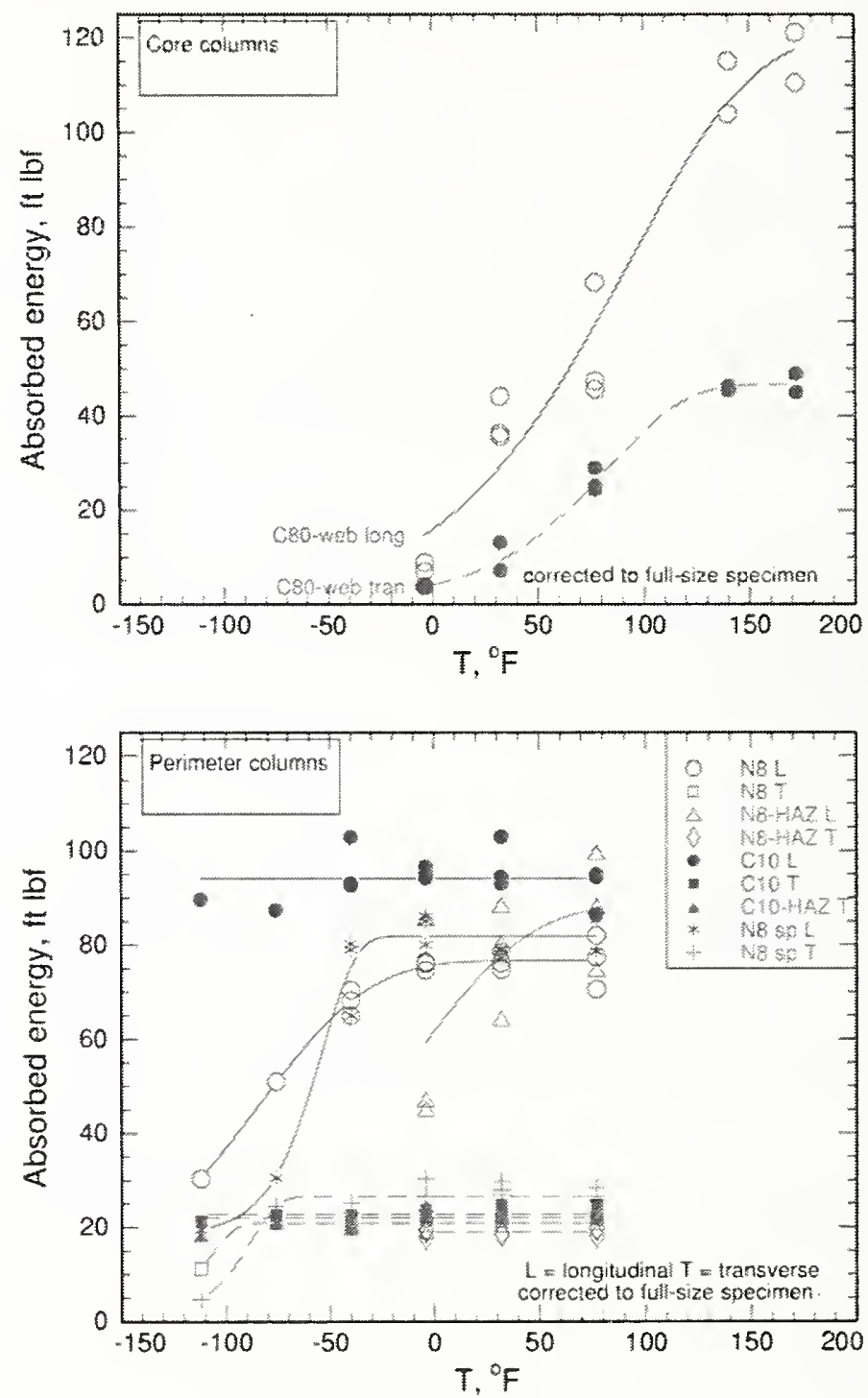

Figure 7-7. Summary data for Charpy tests. Lower figure: perimeter column steels; upper figure: core column steels.

Current building construction specifications, as well as those of the WTC construction era, do not generally specify minimum requirements for Charpy absorbed energies. The room temperature absorbed energy values of the WTC steels tested are similar to those of construction steels of the WTC era. 


\subsection{HIGH-TEMPERATURE TESTS}

The high-temperaturc testing program had two thrusts. One was to characterize the elevated tcmperature stress-strain behavior of the steels most likely to have been affected by the post-impact fires. The second was to characterize the creep, or time-dependent deformation, behavior of the steels from the floor trusses, which are the steels most likely to have been subject to the conditions where crecp deformation can be significant. In each of these two areas, in addition to the expcrimental characterization, NIST developed methodologies to predict the behavior of the untested stcels.

For the elevated temperature stress-strain behavior, the methodology recognizes that the yield and tensile strengths of structural steels, normalized to their room temperature values, follow a master curve with temperature. Figures 7-8 and 7-9 illustrate this behavior for the yicld and tensile strengths of a largc group of structural steels from the literature. The solid curves are the mathematical representations of the behavior. Overlaid on these are the data collected as part of the WTC investigation and the literature data used to develop the master-curve. At the highest temperatures the WTC data lie slightly below the master curve, which was developed by NIST early in the investigation, before significant testing was complete. Like some of the room-temperature data, this difference probably arises because tests in the investigation used a strain rate that was lower than the rate used to generate the literature data. Strain rate effects on the flow stress, which are small at room temperature, become increasingly significant with increasing temperature.

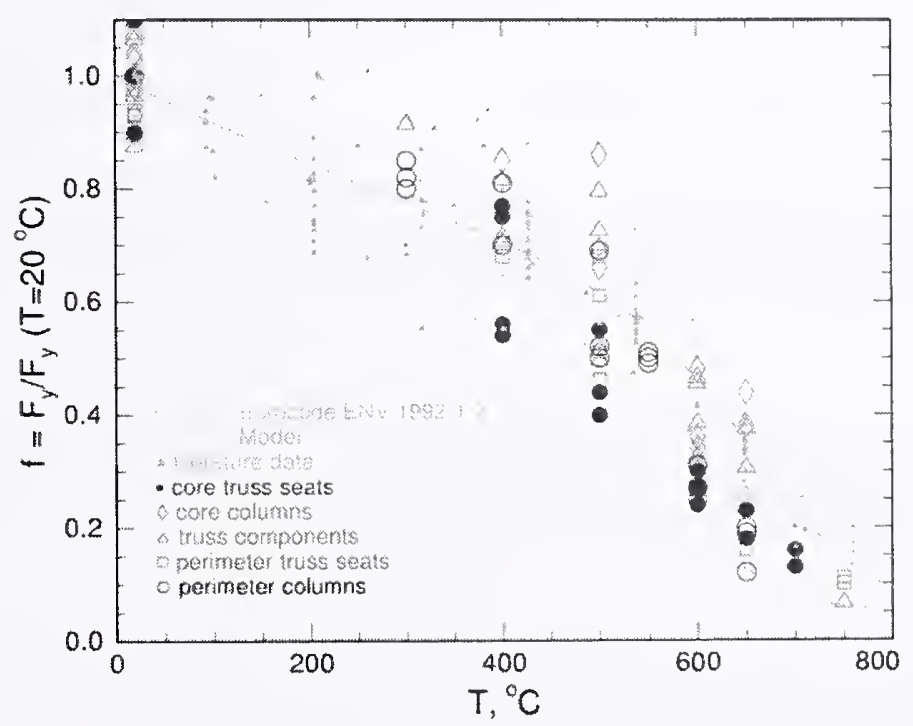

Figure 7-8. Normalized yield strength as a function of temperature for WTC steels, the recommended function to describe behavior (solid line), and the literature data used to develop that relation. 


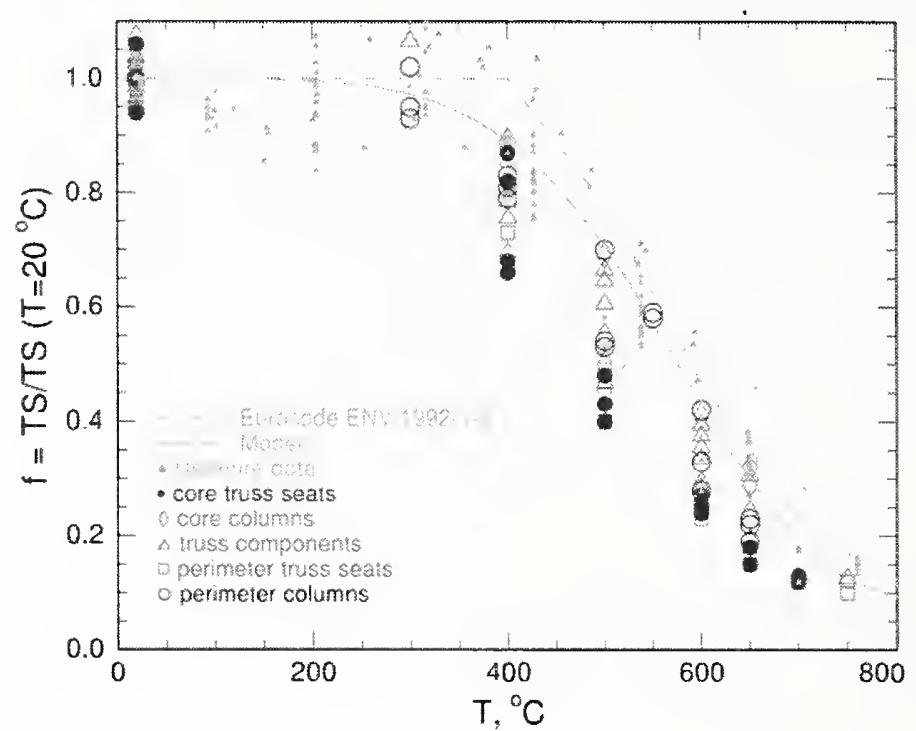

Figure 7-9. Normalized tensile strength as a function of temperature for WTC steels, the recommended function to describe behavior (solid line), and the literature data used to develop that relation.

A modified form of this master strength curve, developed using literature data on bolt steels, describes the strength degradation of the bolts with temperature.

NIST characterized the high-temperature tensile behavior deformation of 15 different steel specimens: three perimeter columns, four core columns, three truss components, and five truss seats. Figure 7-10 is an example of typical high-temperature tensile stress-strain curves from a wide-flange core column in the fire and impact zone of WTC 1.

To produce the elevated-temperature stress-strain curves of WTC steel, NIST developed a methodology for accounting for the change in the work-hardening behavior, using literature data for structural steels scaled by the ratio of room temperature tensile strengths.

Data exist for creep and failure of hundreds of different high-temperature alloy steels intended for use at high temperature. These studies typically focus, however, on the long-time, low-stress conditions these steels see in power-generation and chemical plant operation, rather than the short-time, high-stress conditions structural steels experience in building fires. Consequently, NIST also characterized the creep deformation behavior of the floor truss steels. Figure 7-11 illustrates a set of creep curves for the $F_{y}=50 \mathrm{ksi}$ floor truss steel from the truss chords. The dashed lines, which are not fits to the individual creep curves, represent the predicted creep strains from the global model for creep of the truss steel, which was developed for all stresses and $400{ }^{\circ} \mathrm{C}<T<650{ }^{\circ} \mathrm{C}$. The global model represents the creep strain, $\varepsilon_{l}$, as independent functions of time, $t$, and stress, $\sigma$ :

$$
\varepsilon_{c}=A t^{B} \sigma^{C}
$$


where $A, B$, and $C$ are all functions of temperature. For estimating the creep propertics of untested stccls, NIST developed a methodology to use either cxisting litcrature data or the investigation-gencratcd floor truss steel data after scaling by the ratios of room temperaturc tensile strength.

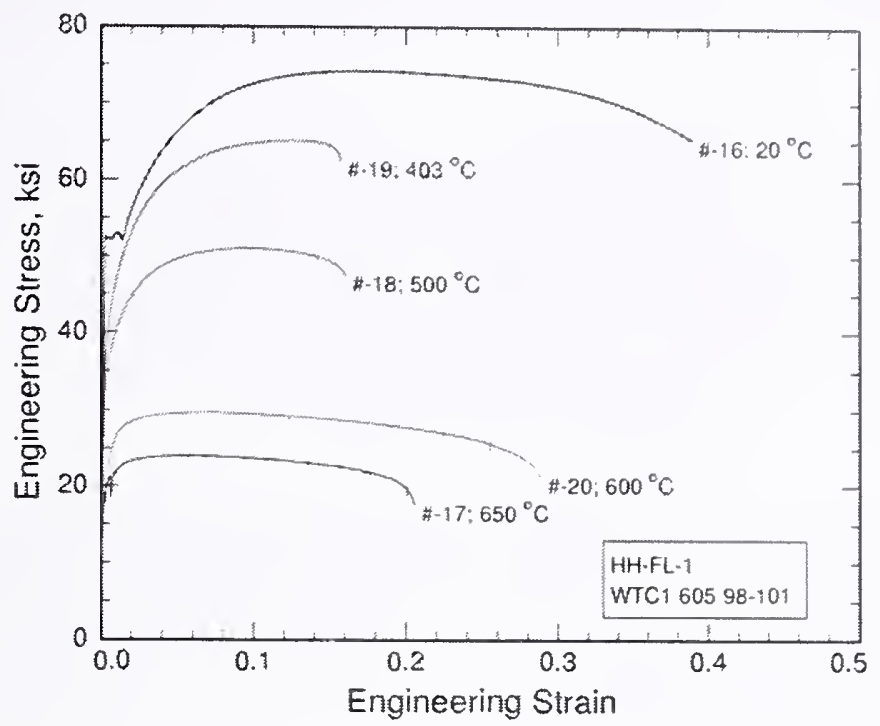

Figure 7-10. Typical high-temperature stress-strain curves for specimen $\mathrm{HH}$, a $F_{y}=\mathbf{4 2} \mathrm{ksi}$ wide-flange shape from near the fire and impact zone of WTC 1.

\subsection{STEELS USED IN WTC 7}

Unlike WTC 1 and WTC 2, no recovered steel in the NIST inventory can be unambiguously assigned to WTC 7. Therefore, properties of the steel were estimated completely from the literature.

\subsubsection{Steels Used in Construction of WTC 7}

Building plans called for rolled column shapes conforming to two ASTM grades: A 36 and A 572 Grade 50. The heaviest rolled columns were additionally built up with cover plates that were specified to several different ASTM specifications, including A 36, A 572 (Grade 42), and A 588 (Grades 42 and 50).

About 26,000 tons of steel went into WTC 7 (Salvarinas 1986). Construction documents in the NIST archives did not provide any information on steel suppliers, but a telephone interview with the former project manager for the construction of WTC 7 yielded some information (Salvarinas 2003).

TradeARBED supplied the jumbo columns for the base of the building to ASTM specifications. British Steel (now Corus) and Bethlehem Steel supplied A 36 and Grade 50 steel. Algoma Steel supplied most of the beams used for the floors. These were rolled to a proprietary Algoma shape that was approximately $41 \mathrm{lb} / \mathrm{ft}$ (Salvarinas 2003). They were supplied to meet Canadian Standard CSA G40.21 ("General Requirements for Rolled or Welded Structural Quality Steel/Structural Quality Steel") Grade 44W, an $F_{y}=44$ ksi steel, where the "W" designates "weldable." 


\subsubsection{Mechanical Properties of WTC 7 Steel}

NIST has found no evidence that the elastic modulus or Poisson's ratio differs between structural steels. Figure 7-1 describes elastic modulus for structural steel as a function of temperature.

Because NIST recovered no steel from WTC 7, it is not possible to make any statements about its quality.

The recommended values for the stress-strain behavior were estimated using the same methodology that was used for the WTC 1 and WTC 2 steels (NIST NCSTAR 1-3D). The static yield strengths were estimated from historical averages and corrected for testing rate effects.

Because, prior to collapse, WTC 7 did not suffer any high-strain rate events, NIST made no effort to estimate high-strain-rate or impact properties of the steel.

The elevated-temperature stress-strain curves were estimated using the same methodology as used for the steels in WTC 1 and WTC 2 (NIST NCSTAR 1-3D). The elevated temperature stress-strain curve is modeled using power-law work-hardening, where the degree of work-hardening depends on temperature and the calculated stress is scaled by the ratio of the estimated tensile strength of the WTC 7 steel to that of the reference steel used to develop the model.

Creep behavior was estimated using the same methodology that was used for the steels in WTC 1 and WTC 2, in which the creep strain as a function of time depends on stress and temperature (NIST NCSTAR 1-3D). The applied stress was scaled by the ratio of the tensile strength of the steel in question to that of the reference AS A149 steel used to develop the creep model.

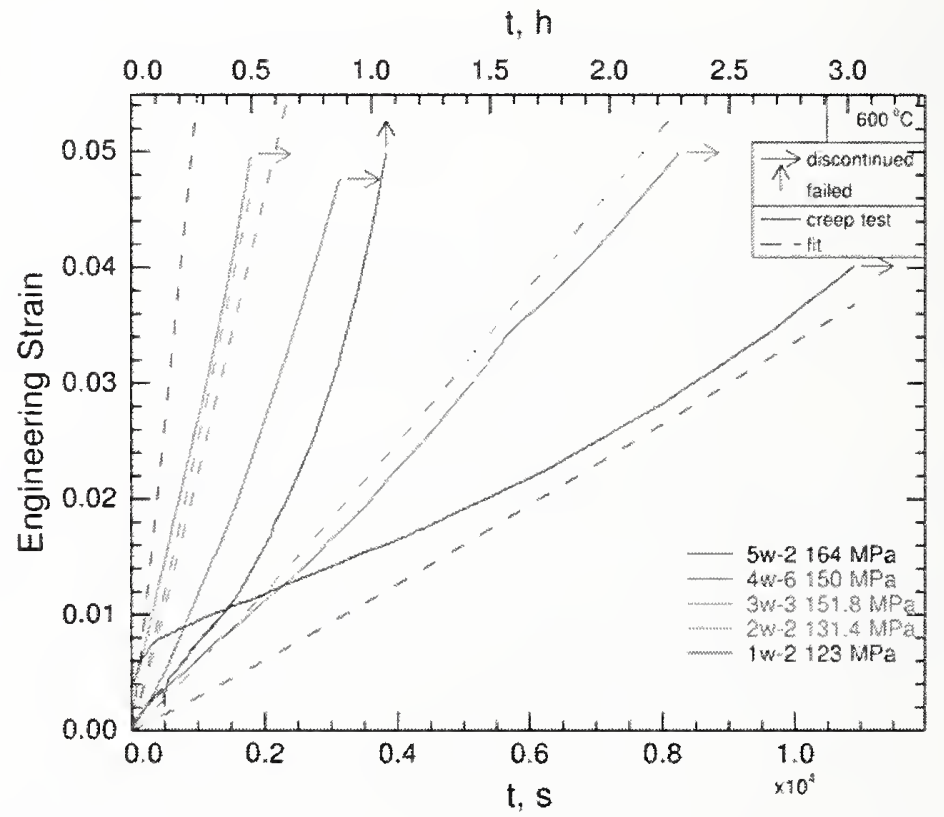

Figure 7-11. Typical creep curves for different stresses at $600{ }^{\circ} \mathrm{C}$ from truss steels specified as $\mathrm{A} 242$, from specimen C132-TA. 


\subsubsection{Physical Properties of WTC 7 Steel}

No metallography could be carried out because no steel was recovered from WTC 7. Other physical properties are the samc as those estimated in Chapter 8 for the WTC stecls.

\section{8 $\quad$ FINDINGS}

\subsubsection{Room Temperature Tensile Properties}

Steels of the same nominal strength supplicd by different steel producers often have different mechanical behavior. There were over 40 different stecls in the towers, based on the various combinations of suppliers and nominal strengths. Thirty-two steels were sufficiently different to require distinct models of constitutive behavior.

The steel used in the construction of the WTC generally met the expectations of the designers and the specifications called for in the steel contracts. Approximately 87 percent of all tested steel excecded the required minimum yield strengths specified in design documents; approximately 13 percent of test results on the damaged steel did not meet the required minimam yield strengths. The occurrence of test results below the specified minimum values is not unexpected since differences in test procedures from those in the qualifying mill tests could account for $2-3 \mathrm{ksi}$ lower values in the NIST tests, and the loss of a yield point due to damage to the steel accounts for 2-5 ksi lower values in the NIST tests in several cases.

The mechanical properties and chemistry of the perimeter column steels were consistent with the requirements of the intended specifications. Their yield strengths generally exceeded their specified minimums by more than 10 percent. Their tensile properties were also consistent with literature estimates for average properties of structural steel plate during the WTC construction era. The number of occurrences of plates with tensile properties at or slightly below the specified minimum is consistent with the historical variability of steel strength.

The mechanical properties and chemistry of the core column steels were generally consistent with the requirements of the intended specifications. Some, primarily wide-flange shapes, had NIST-measured strengths that were lower than called for in the specifications, but this may have arisen from mechanical damage that removed the yield point, the natural variability of structural stecl, and slight differences between the NIST and original mill test report testing protocols. However, the yield strengths of undamaged steels in the rolled core columns were lower than the historical literature indicates as typical. The observed distributions are accounted for in the typical design factor of safety for allowable stress design.

The mechanical properties and chemistry of the steels in the floor trusses were consistent with the requirements of the intended specifications. The strength of the steel in the floor trusses was higher than called for in the original specifications. Many of the truss steels specified as low strength A 36 were supplied as HSLA steels with much higher strengths. Laclede Steel Company's substitution of $50 \mathrm{ksi}$ yield strength steel for A 36 in the lower chord of the trusses is expected to have provided significantly improved performance at high temperature. 
Limited tests on recovered bolts indicated that their mechanical properties and chemistry were consistent with their intended specifications. Furthermore, the recovered bolts were stronger than contemporaneous literature suggests as typical.

Limited tests on recovered welds and weld material indicated that their mechanical properties and chemistry were consistent with their intended specifications.

In summary, the steel used in the construction of the WTC towers met the expectations of the designers and had properties consistent with the requirements of the specifications called for in the steel contracts. The observed distributions of yield strength are accounted for in the typical design factor of safety for allowable stress design. Material substitutions of higher strength steels were common in the perimeter columns and floor trusses. The safety of the WTC towers on September 11,2001, was most likely not affected by the fraction of steel that, according to NIST testing, did not meet the required minimum yield strength. The typical factors of safety in allowable stress design can accommodate the measured property variations below the minimum.

\subsubsection{High-Strain Rate Properties}

The strain rate sensitivity and high-strain rate ductility of the perimeter and core column steels were similar to other structural steels of the WTC era.

\subsubsection{Impact Properties}

The impact toughness of steels from the perimeter and core columns, and floor trusses was consistent with literature values for the WTC construction era.

\subsubsection{High-Temperature Properties}

The high-temperature yield and tensile strength behavior of WTC steels was similar to behavior of structural steels from the WTC construction era literature.

The creep behavior of WTC steels was modeled by scaling WTC-era literature data using room temperature tensile strength ratios.

Laclede Steel Company's substitution of 50 ksi yield strength steel for A 36 in the lower chord of the trusses is expected to have provided significantly improved performance at high temperature.

\subsection{REFERENCES}

ASM (American Society of Metals) International. 1978. Properties and Selection: Irons and Steels. Metals Park, $\mathrm{OH}$.

Clark, C.L. 1953. High-Temperature Alloys. Pitman, NY.

Cooke, G.M.E. 1988. An Introduction to the Mechanical Properties of Structural Steel at Elevated Temperatures. Fire Safety Journal, 13, 45-54. 
Dever, D.J. 1972. Temperature Dependence of the Elastic Constants in a-Iron Single Crystals: Relationship to Spin Order and Diffusion Anomalies. J. Appl. Phys., 43(8). 3293-3301.

Fields, R.J., T. Weerasooriya, and M. F. Ashby. 1980. Fracture-Mechanisms in Pure Iron, Two Austenitic Stainless Steels, and One Ferritic Stcel. Met. Trans. A. 11 A, 333-347.

Köster, W. 1948. Die Temperaturabhängigkeit des Elastizitätsmoduls reiner Metalle, Z. Metallkd., 39(1). $1-9$.

Salvarinas, John J. 2003. Telephone interview with William Luecke, National Institute of Standards and Technology, Gaithersburg, MD. Salvarinas was the projeet manager for Frankel Steel during the erection of WTC 7. May 16.

Salvarinas, John J. 1986. Seven World Trade Center, New York, Fabrication and Construction Aspects. Canadian Structural Engineering Conference-1986 Proceedings. Canadian Struetural Stcel Council, Willowdale, Ontario, Canada. ISBN 0-88811-062-6, pages 11-1 to 11-44.

Uddin T., and C. G. Culver. 1975. Effects of Elevated Temperature on Structural Members. J. Struct. Div. ASCE. 101(7). 1531-1549. 
This page intentionally left blank. 


\section{Chapter 8 \\ Physical Properties of Structural Steels}

\section{$8.1 \quad$ INTRODUCTION}

A number of physical propertics of the structural stcel from the towers werc cither measurcd or cstimatcd. Of thesc, composition and microstructure were characterized for many of the recovered pieces in order to identify the specifications to which the stecl was fabricated, enabling a better characterization of the mechanical properties of the steel. In addition, various thcrmal properties were cstimatcd as a function of temperature based on litcrature data in order to provide input to models of the steel thermal responsc to the fires.

\subsection{CHEMICAL ANALYSIS OF RECOVERED STEEL}

In addition to mechanical propertics, steel specifications give chemical composition limits for particular steels. Thus knowledge of the composition can help identify the specification to which the steel was produced. In addition, individual steel producers often have favored composition ranges which arc a subset of those allowed by the steel spccification, and a narrow range of analyzed compositions for a given group of steel products suggests that they were produccd by the same stecl mill.

The most common elements in modern steels include the base iron $(\mathrm{Fe})$, carbon $(\mathrm{C})$, mangancse $(\mathrm{Mn})$, silicon $(\mathrm{Si})$, niobium $(\mathrm{Nb})$, vanadium $(\mathrm{V})$, nickel $(\mathrm{Ni})$, chromium $(\mathrm{Cr})$, molybdenum $(\mathrm{Mo})$, coppcr $(\mathrm{Cu})$, aluminum $(\mathrm{Al})$, boron $(\mathrm{B})$, and nitrogen $(\mathrm{N})$. In addition, steels contain the undesirable tramp elements sulfur $(\mathrm{S})$ and phosphorus $(\mathrm{P})$.

Chemical analysis of the recovered World Trade Center (WTC) structural stcel was conducted to help identify the various types and fabricators of the steel. The complete analysis, found in the report Physical Properties of Structural Steels (NIST NCSTAR 1-3E), is summarized below. Nearly every important component of the recovered structural elements was analyzed ( 385 chemical analyses). Since many of the structural elements had stampings indicating the yield strength $\left(F_{y}\right)$ of the steel, grouping of the different strength levels for comparison was possible. Tests were conductcd in accordance with ASTM International (ASTM) E415 for all elements except carbon; ASTM E 1019 was used for this element. The company through which the analysis was done has an annually renewed accreditation with the American Association of Analytical Laboratories.

Additionally, two independent laboratories were sent samples from nearby locations on perimeter column plates. This was done as an independent check on accuracy. Both laboratories obtained similar results. Further, two samples from this group were also analyzed at National Institute of Standards and Technology (NIST) in the Analytical Chemistry Division using X-ray fluorescence (XRF) and Glow Discharge Optical Emission Spectroscopy (GDOES). Both instruments were calibratcd with NIST standard reference materials for steel. Again similar results were observed. 
The analyses of the flange, outer web, and spandrel plates of the exterior panel sections (all Yawata steel) were found to be nearly identical for a given plate grade $\left(F_{y}\right)$ and gauge. In contrast, inner web plates with $F_{y}$ less than $80 \mathrm{ksi}$ were found to be chemically distinguishable from the other plates. For $F_{y}$ equal to $80 \mathrm{ksi}$ and $100 \mathrm{ksi}$, the inner web plates were consistent with the flange compositions, and these plates are therefore believed to be Yawata steel. These results support the contemporaneous documents stating the flange, outer web, and spandrel plates were produced by the Yawata Steel Co., and the inner web plates were primarily supplied domestically. Regardless of supplier, Mn and Si were the primary strengthening additive of the lower strength components. Higher strength components contained $\mathrm{Cr}$ and Mo additions. $\mathrm{Nb}$ and $\mathrm{V}$ additions were used in most of the steels with $45 \mathrm{ksi}$ to $80 \mathrm{ksi}$ specified yield strengths. These alloying practices were typical for steels of this era.

For the limited number of recovered core columns available for evaluation, the chemistry results varied for any given $F_{y}$ and shape (built-up box, rolled wide-flange), consistent with the contemporaneous documents stating that numerous suppliers produced the steel used for these structural components. All tested core columns met chemistry specifications for one of the numerous ASTM structural steel grades available during the construction era.

Floor truss rods and chords, manufactured by Laclede Steel Co., met chemistry specifications for ASTM A 242; the Mn contents were typically too high to meet ASTM A 36 specifications. Contemporaneous construction documents indicated that Laclede Steel Co. routinely upgraded A 36 components to A 242 steel.

A majority of the other structural components (floor truss seats, diagonal bracing straps, gusset plates, core channels, etc.) met chemistry specifications for ASTM A 36 grade steel, which was the default steel when strengths were not specified on the design drawings.

Two types of bolts were specified for construction of the towers, A 325 and A 490 bolts. Stampings on the bolt heads clearly indicated the bolt type. Only one A 325 bolt was tested for chemistry with the results indicating that it met the A 325 Type 1 chemistry specifications.

A piece of the aluminum façade was analyzed and found to be consistent with the non-heat treatable aluminum-manganese alloy AA 3003.

\subsection{METALLOGRAPHY}

Metallography, or study of the microstructure (details of the distribution of elements and phases), can be used to identify how a piece of steel was processed. This information can be useful in identifying the type of steel, certain expected properties, and in a few special cases, help identify the producer. In addition, metallography can be used to identify exposure to extreme temperatures (see Chapter 6).

Thus, in addition to the chemical analysis, metallography of the recovered WTC structural steels was used to confirm the identity of the types of steels. This information is summarized below, with the complete analysis found in the report Physical Properties of Structural Steels (NIST NCSTAR 1-3E). The microstructure of every sample removed from the structural elements was evaluated (862 metallographic samples). This number included base material, viewed in two different orientations, and welded connections. Standard metallographic procedures for grinding, polishing, and etching were used to prepare the samples for examination with light optical microscopy. 
For the exterior panel sections, two different microstructural types werc observed. Flange, web, and spandrel plates with specified minimum yield strengths lcss than $70 \mathrm{ksi}$ were ferritc-pearlitc (Fig. 8-1). Additionally, inner webs with $F_{y}$ of $70 \mathrm{ksi}$ and $75 \mathrm{ksi}$ were ferrite-pearlite. For the Yawata produced plates (flange, outer web, and spandrcl), this type of microstructure was expected given the mcasured plate thickness and speeificd minimum yield strength (refer to NIST NCSTAR 1-3A). Plates with $F$, less than $70 \mathrm{ksi}$ were typically hot rolled unless the following sizes werc cxeecded for a given $F_{y}: 0.5$ " for $65 \mathrm{ksi}, 1.25$ " for $60 \mathrm{ksi}$, and 1.5" for $55 \mathrm{ksi}$. For these specified plates, as well as those with minimum yield strengths equal to or greatcr than $70 \mathrm{ksi}$, "quenchcd-and-tempcred" mierostructures werc obscrved (Fig. 8-2).
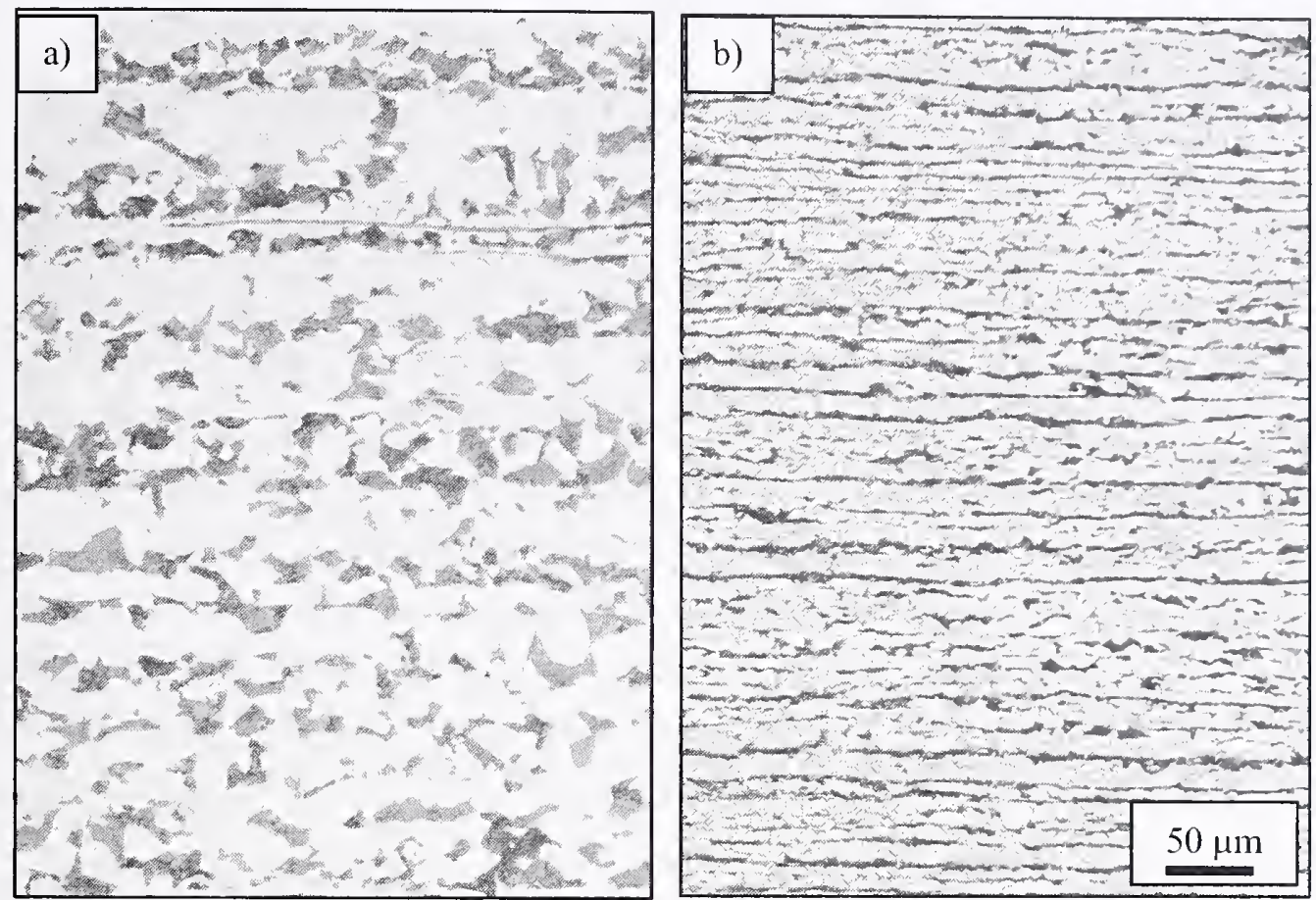

Figure 8-1. Microstructure of ferritic-pearlitic WTC perimeter column flange plate steels. a) $F_{y}=45 \mathrm{ksi}$ (unidentified perimeter column with " 45 " flange stamping) and b) $F_{y}=60 \mathrm{ksi}$ (WTC 1, column 126, 97th floor).

Microstructure varied within each of the two structure types, depending on produet type, gauge, and strength level. Ferrite-pearlite steels had variations in ferrite grain size, ferrite grain shape, pearlite lamellar spaeing, and banding of microstructural constituents with a change in specified $F_{y}$ and gauge of the plate. Examples of these microstructures are shown in Fig. 8-1. Similarly, the quenched and tempered steels had variations with $F_{y}$. Plates with $F_{y}=70 \mathrm{ksi}$ had a coarse Widmanstatten morphology of ferrite with coarse eementite precipitates while the higher strength plates had what appeared to be a tempered martensitie structure, as shown in Fig. 8-2.

With the exception of the column end plates and construetion bolts, all other struetural elements evaluated had ferrite-pcarlite mierostruetures. These inelude the core columns, floor truss connectors, floor truss rods and ehords, and the core channels. The end plates and bolts had quenehed-and-tempered microstructures. 

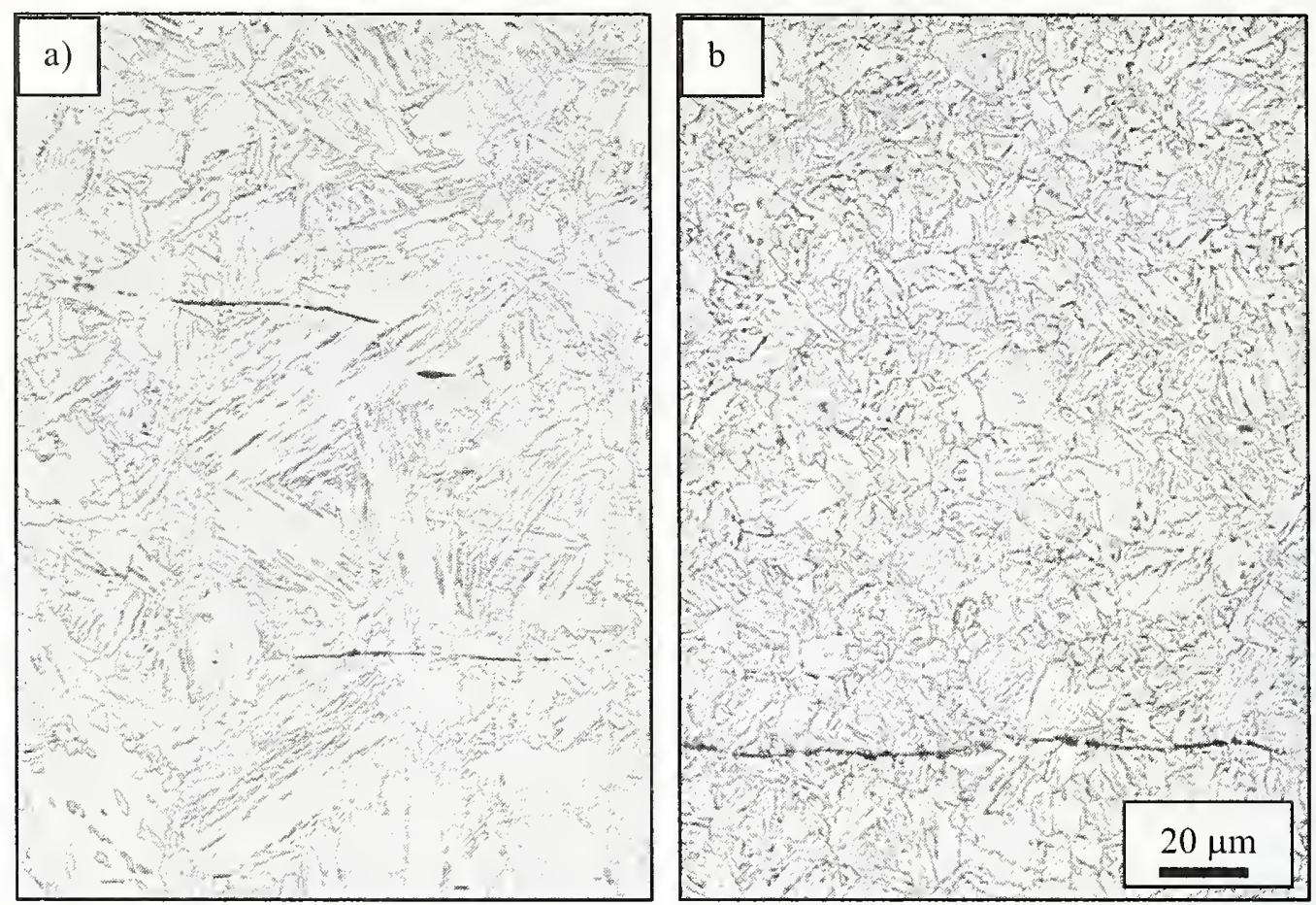

Figure 8-2. Examples of "quenched and tempered" WTC perimeter column flange steel. a) $F_{y}=70 \mathrm{ksi}$ (WTC 1, column 224, 94th floor) and b) $F_{y}=80 \mathrm{ksi}$ (WTC 1, column 207, 89th floor).

For each of the designated minimum yield strengths, the type of structures observed was expected for steels of that era. While the microstructural features may have varied from plate to plate, there was no indication that the practices followed to produce the plates were improper.

\subsection{THERMAL PROPERTIES}

The following thermal properties as a function of temperature were determined, based on literature data, as needed for modeling of the building response to the fires.

- Specific heat $\left(C_{p}\right)$

- Coefficient of thermal expansion $(\alpha)$

- Thermal conductivity, $k$,

Of these, only the thermal conductivity varies by more than a few percent among the different steels used in the building.

In general, properties are reported from room temperature up to $600^{\circ} \mathrm{C}$ or $700{ }^{\circ} \mathrm{C}$. Near $720^{\circ} \mathrm{C}$ ironcarbon alloys such as structural steel transform from a mixture of $\alpha$-phase (ferrite) and cementite $\left(\mathrm{Fe}_{3} \mathrm{C}\right.$ ) to a mixture of $\alpha$ and $\gamma$ (austenite). Most thermostructural properties are discontinuous at this transition, and the heat capacity becomes infinite. Furthermore the literature contains much less information on properties at temperatures higher than the phase transformation. Generally, though, the strength of steel above the phase transformation is reduced to 10 percent or less of the room-temperature value. 
The specific heat at constant pressurc is defincd as

$$
C_{p}=\left(\frac{d q}{d T}\right)_{p}
$$

where $q$ is the heat added per unit mass. Bccausc structural stecls gencrally contain very low fractions of alloying elements it is possible to use the heat capacity as a function of tempcraturc for purc iron without introducing an error of morc than 3 percent.

Of the many expcrimental determinations, that of Wallace (1960) spans the tempcrature range of interest, is relatively recent, and has an uncertainty statement. To represent the data we fit a third-order polynomial to the data in the rangc $0{ }^{\circ} \mathrm{C}<T<650{ }^{\circ} \mathrm{C}$ :

$$
\begin{aligned}
& C_{p}(T)=c_{0}+c_{1} T+c_{2} T^{2}+c_{3} T^{3} \\
& \text { where } \\
& c_{0}=51.11 \pm 33.39 \\
& c_{1}=2.019 \pm 0.185 \\
& c_{2}=(-3.0135 \pm 0.320) \times 10^{-3} \\
& c_{3}=(1.829 \pm 0.175) \times 10^{-6}
\end{aligned}
$$

where $C_{p}$ is expressed in $\mathrm{J} /(\mathrm{kg} \mathrm{K})$ and $T$ in kelvins.

The coefficient of thermal expansion (CTE), $\alpha$, is used to predict the length of a member, $L$, as a function of temperature, $T$. Therc arc two common definitions. The mean CTE, $\alpha_{M}$, is simply the two point slope of the length of the specimen at two temperatures. As such, it ignores any changes in slope between the two fixed points.

$$
\alpha_{M}=\frac{L_{2}-L_{1}}{L_{1}\left(T_{2}-T_{1}\right)}
$$

The instantaneous CTE, $\alpha$, which permits integration along the temperature path to find the length of a member at any temperature is defined as

$$
\alpha=\frac{1}{L}\left(\frac{\partial L}{\partial T}\right)
$$

Because the litcrature provides no evidence of a relation between stecl chemistry and thermal expansion coefficient, the recommended value is that for pure iron (Touloukian 1977)

$$
\begin{aligned}
& \alpha(T)=\alpha_{0}+\alpha_{1} T+\alpha_{2} T^{2}+\alpha_{3} T^{3} \\
& \text { where } \\
& \alpha_{0}=7.3633 \times 10^{-6} \\
& \alpha_{1}=1.8723 \times 10^{-8} \\
& \alpha_{2}=-9.8382 \times 10^{-12} \\
& \alpha_{3}=1.6718 \times 10^{-16}
\end{aligned}
$$

and $T$ is measured in kelvins, for $300 \mathrm{~K}<T<900 \mathrm{~K}$. 
For one-dimensional heat flow, the thermal conductivity, $k$, relates the quantity of heat per unit time, $Q$, transported per unit area, $A$, to the temperature gradient $\partial T / \partial x$ :

$$
\frac{Q}{A}=k\left(\frac{\partial T}{\partial x}\right)
$$

and has units of $W /(m \cdot K)$. For one-dimensional situations where the temperature depends on time, the thermal diffusivity, $\alpha$, is appropriate

$$
\frac{\partial T}{\partial t}=\alpha \frac{d^{2} T}{d x^{2}}
$$

The thermal diffusivity, $\alpha$,

$$
\alpha=\frac{k}{\rho C_{p}}
$$

is the ratio of the thermal conductivity, $k$, to the density, $\rho$, and specific heat $C_{p}$. Thermal diffusivity has units of a diffusion coefficient: $\mathrm{m}^{2} / \mathrm{s}$.

Unlike the other thermal properties (modulus, CTE, specific heat), thermal conductivity is affected by the microstructure of the steel: identical compositions processed differently will yield steels with different thermal conductivities. Because the various alloying elements and processing steps modify the microstructure, there is no generic relation between grade of steel and thermal conductivity. For instance, the plot in Fig. 8-3 shows the thermal conductivity as a function of temperature for 12 low-alloy steels. Even near room temperature, the data span 40 percent of the mean value.

Using literature data from a statistically planned experiment, it was possible to develop an expression for the thermal conductivity that attempts to account for chemical variations. This expression is only partially useful because it requires that the chemistry of the steel be known, which is not possible for a generic construction element in the WTC towers. Using the specified minimum values for chemistries in the steels does not help, because the unspecified elements can make a contribution equal to or greater than the ones in the specification.

\subsection{SUMMARY}

\subsubsection{Chemistry of WTC Steels}

Chemical analyses of the flange, outer web, and spandrel plates of the exterior panel sections were found to be nearly identical for a given plate gauge and yield strength. In contrast, inner web plates with yield strengths less than $80 \mathrm{ksi}$ were found to be chemically distinct from the other plates; inner webs with strengths equal to $80 \mathrm{ksi}$ and $100 \mathrm{ksi}$ were the same steel as used for the flanges. These results support the contemporaneous documents stating that the flange, outer web, and spandrel plates were produced by a single company (Yawata Iron and Steel Co.), and the inner web plates were primarily supplied domestically. End plates of the perimeter panel met chemistry specifications for Yawata steels, as well. The alloying practices observed were typical for steels of this era. 


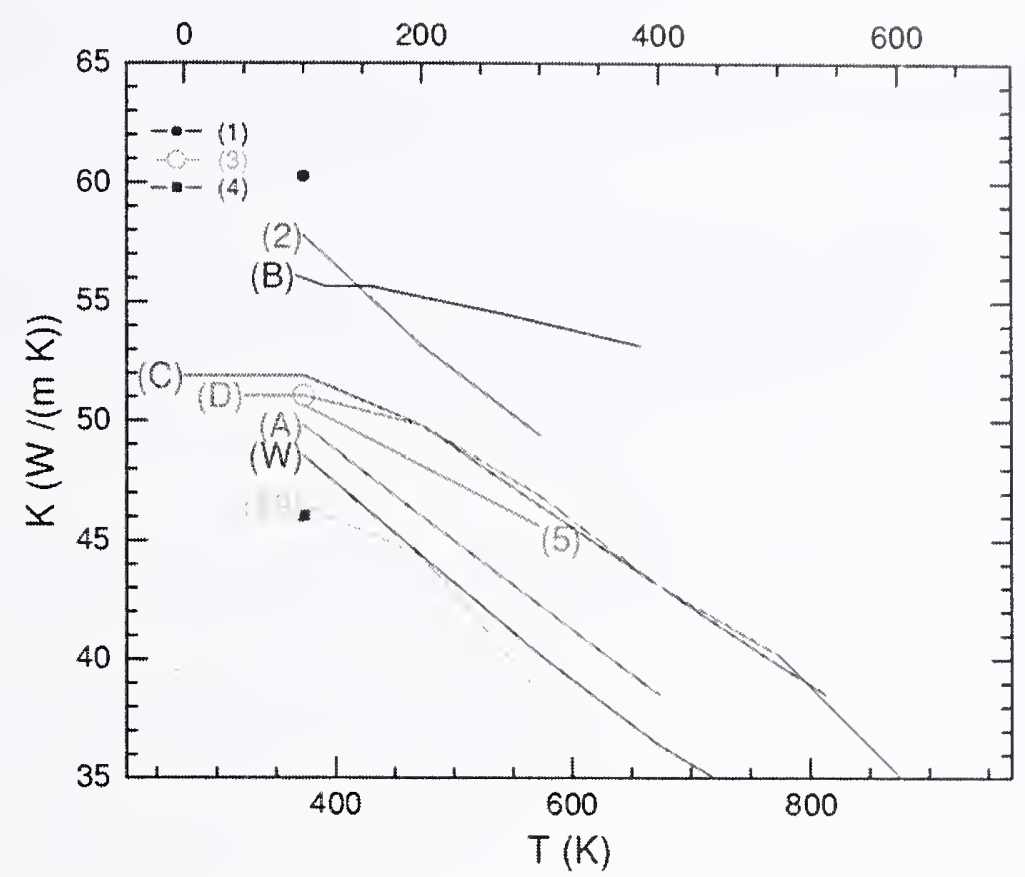

Source: Numbered curves correspond to steels in a report from the National Physical Laboratory (NPL 1946). Curves A-C correspond to curves 22, 24, and 79 of Specification Table 334 in Touloukian (1970b). Curve D appears in Specification Table 335 in Touloukian (1970b); the original data are from Powell (1956). Curve $W$ comes from a data sheet for WEL-TEN 80. (Yawata 1969).

Figure 8-3. Thermal conductivity as a function of temperature for twelve low-alloy steels.

The recovered core columns were found to vary in composition for a given strength and shape (built-up box, rolled wide flange). This result supports the contemporaneous documents stating that numerous suppliers produced the steel to be used for these structural components.

Construction bolts were either A 325 or A 490 bolts. Bolt types were identified by stampings on the head. Chemical analysis indicated the A 325 bolts met the Type 1 chemistry specifications.

Chords and rods that composed the floor trusses were either ASTM A 36 or ASTM A 242. Laclede Steel Co., the truss fabricator, supplied these materials.

Other structural elements (floor truss connectors, core channels, spandrel splice plates, etc.) met specifications for ASTM A 36. Compositions varied significantly, and it appears that numerous suppliers completed the steel orders for these components.

\subsubsection{Microstructure of WTC Steels}

Two different microstructural types were observed for the recovered WTC steels: ferrite-pearlite for low strength components and quenched-and-tempered for high-strength components.

Discernible changes to the microstructure of furnace exposed WTC steel were observed when exposed to a temperature of $625^{\circ} \mathrm{C}$ for as little as $0.25 \mathrm{~h}$. At or below $500^{\circ} \mathrm{C}$, no microstructural change was 
apparent using light optical microscopy. The hardncss of these samples varied for a given temperature and material type, but correlated well with microstructural observations.

\subsubsection{Thermal Property Values of WTC Steels}

Thermal property values as a function of temperature were provided for modeling the structural steel rcsponse to fire. These properties include specific heat $\left(\mathrm{C}_{\mathrm{p}}\right)$, coefficient of thermal expansion $(\alpha)$, and thermal conductivity $(\mathrm{k})$.

\subsubsection{Other}

A piece of the aluminum façade was analyzed and found to be consistent with the non-heat treatable aluminum-manganese alloy AA 3003.

A sample of fireproofing material was chemically analyzed. While the chemical composition of the material was proprietary, the results were found to be consistent, on a qualitative basis, with the information presently available on the manufacturer's website.

\subsection{REFERENCES}

American Institute of Steel Construction. 1973. Mannal of Steel Construction, American Institute of Steel Construction, New York, p. 6-11.

ASM (American Society of Metals) International. 1978. Properties and Selection: Irons and Steels, ASM International, Metals Park, OH.

Clark, C.L. 1953. High-Temperature Alloys, Pitman, NY.

Cooke, G. M. E. 1988. An Introduction to the Mechanical Properties of Structural Steel at Elevated Temperatures, Fire Safety Journal, 13, 45-54.

Dever, C.J. 1972. Temperature Dependence of the Elastic Constants in a-Iron Single Crystals: Relationship to Spin Order and Diffusion Anomalies, J. Appl. Phys., 43 (8), 3293-3301.

Fields, R.J., T. Weerasooriya, and M. F. Ashby. 1980. Fracture-Mechanisms in Pure Iron, Two Austenitic Stainless Stcels, and One Ferritic Steel, Met. Trans., A 11A, 333-347.

Harmathy, T.Z., and W. W. Stanzak. 1970. Elevated-Temperature Tensile and Creep Properties of Some Structural and Prcstressing Steels, Fire Test Performance, vol. ASTM STP 464, American Society for Testing and Materials, 186-208.

Köster, W. 1948. Die Temperaturabhängigkeit des Elastizitätsmoduls reiner Metalle, Z.Metallkd. 39 (1), $1-9$.

Ludwigson, D. C., and F. C. Schwerer. 1971. The Effect of Composition on the Resistivity of Carbon Steel Sheet, Metall. Trans., 2, 3500-3501. 
NPL. 1946. The Physical Properties of a Series of Steels.-Part II, J. Iron Steel Inst., 154, 83P-121P.

Powell, R. W., and R. P. Tye. 1956. Thermal Conduetivity and Eleetrical Resistivity of a $0.4-0.5 \%$ Manganese Steel, J. Iron Steel Inst., 184, 286-288.

Schwerer, F. C., and R. M. Fisher. 1986. Steels: Electrical Resistivity and Thermal Conductivity, The MIT Press, Cambridge, MA, p. 4601.

Souder, W., and P. Hidnert. 1922. Thermal Expansion of a Few Steels, Sci. Pap. Bur. Stand., 17 , 611-626.

Touloukian, Y. S., and Buyeo, E. H. 1970a. Specific Heat Metallic Elements and Alloys, IFI/Plenum, NY.

Touloukian, Y. S., Powell, R. W., Ho, C. Y, and Klemens, P. G. 1970b. Thermal Conductivity Metallic Elements and Alloys, IFI/Plenum, NY.

Touloukian, Y. S., Kirby, R. K., Taylor, R. E., and Desai, P. D. 1977. Thermal Expansion Metallic Elements and Alloys, IFI/Plenum, NY.

Uddin, T., and C. G. Culver. 1975. Effeets of Elevated Temperature on Struetural Members, J. Struct. Div. ASCE 101 (7), 1531-1549.

Wallaee, D.C., P. H. Sidles, and G. C. Danielson. 1960. Speeifie Heat of High Purity Iron by a Pulse Heating Method, J. Appl. Phys., 31 (1), 168-176.

Yawata Iron and Steel Co. 1969. WEL-TEN 80, Japan, 142-164. 
This page intentionally left blank. 


\section{Chapter 9 \\ FINDINGS AND ISSUES}

\section{$9.1 \quad$ INTRODUCTION}

This chapter summarizes the findings and conclusions from the NIST mcchanical and mctallurgical analysis of the WTC structural stccl.

\subsection{FINDINGS - STEEL SPECIFICATIONS, STANDARDS, AND SOURCES}

Fourteen nominal strengths of steel were specified in the structural engineering plans, but only 12 strengths of steel (minimum yicld strengths of $[36,42,45,46,50,55,60,65,70,75,80$, and 100] ksi) were actually used in construction due to an upgradc of two steels ( $85 \mathrm{ksi}$ and $90 \mathrm{ksi}$ stccl upgraded to $100 \mathrm{ksi})$.

Ten different steel companies fabricated structural elements for the towcrs, using steel supplicd from at least eight different suppliers. Four fabricators supplied the major structural elements of the 9th to 107 th floors: Laclede Steel (floor trusses), Pacific Car \& Foundry (perimeter column panels), Stanray Pacific (welded core box columns), and Montague-Betts (rolled core columns).

Although ASTM International structural steel standards have evolved since the construction of the towers, the changes have been minor and do not represent changes to the basic mechanical properties of the steels.

\subsection{FINDINGS - INVENTORY OF RECOVERED STRUCTURAL STEEL}

National Institute of Standards and Technology (NIST) has 236 samples from the World Trade Center (WTC) buildings, the majority belonging to WTC 1 and WTC 2. These samplcs represent roughly 0.25 percent to 0.5 percent of the 200,000 tons of structural steel used in the construction of the two towers.

The collection of steel from the WTC towers was sufficient for determining the quality of the steel and, in combination with published data, for providing mechanical propertics as input to models of building performance.

The original as-built locations of 42 recovered perimeter panels and 12 recovered core columns were determined. Representative samples exist for all 12 grades of perimeter panel material, two grades of the core column material (reprcsenting 99 percent of the total number of columns), and both grades for the floor truss material.

A number of structural pieces were recovered from locations in or near the impact and fire damaged regions of the towers, including four exterior panels directly hit by the airplane and three core columns located within these areas. 
Material substitutions of higher strength steels were not uncommon in the perimeter columns and floor trusses.

\subsection{FINDINGS - DAMAGE AND FAILURE ANALYSIS}

Damage and failure analysis findings were made based on pre-collapse photographs of the recovered steel. It should be noted that the recovered steel represents only a small fraction of the structural steel in the towers and that the recovery effort focused on apparent fire and impact damage.

\subsubsection{Structural Impact Damage - Perimeter Panels}

Damage modes due to direct aircraft impact were documented based on pre-collapse photographs.

Correlation between pre-collapse photographs and the recovered panels from the impact zone indicates that two of the four recovered impact-damaged panels (M-2 and M-30) are in a condition similar to that just prior to building collapse. Some damage can be attributed to the events during and after collapse, but the general shape and appearance of the recovered pieces match with the damage photographs.

Of particular interest was the fracture behavior of the plates composing the recovered columns that were directly impacted by the airplane. Fractures of the plates in areas away from a welded joint (e.g., fracture occurring perpendicular to the rolling direction of the outer webs of panels M-30 and S-9) exhibited ductile behavior, including necking and thinning away from the fracture, indicating that the steel behaved ductilely under very high-strain rates.

Conversely, fractures occurring parallel and directly next to a welded joint exhibit little or no ductile characteristics. Diminished properties of the heat affected zone in the base plate, the geometry of the joint with respect to the direction of impact, stress concentrations due to the geometry, and the orientation of the crack propagation with respect to the rolling direction of the plate are expected to contribute to the lack of ductility. There was no evidence to indicate that the type of joining method, materials, or welding procedures were improper. The welds appeared to perform as intended.

In general, severing of the perimeter columns hit by an aircraft wing occurred at an internal stiffener plate or diaphragm plate (associated with the spandrel connection to column). There was a tendency for the columns hit by the plane to have experienced metal fracture paths along heat-affected zones adjacent to welds. This behavior was not observed for columns outside of the impact zone.

The failure mode of spandrel connections on perimeter panels differed above and below the impact zone. Spandrel connections on exterior panels at or above the impact zone were more likely to experience bolt hole tear out as a failure mode. For those exterior panels below the impact zone, there was a higher propensity for the spandrels to be ripped off from the panels. This may be due to shear failures as the weight of the building came down on these lower panels. There did not appear to be any difference in failure mode for the spandrel connections whether the exterior panels were exposed to fire or not.

With the exception of the mechanical floors, the major failure mechanism concerning perimeter panel column splices was fracture of the bolts. At mechanical floors, where splices were welded in addition to being bolted, the majority of the splices did not fail. 


\subsubsection{Structural Impact Damage - Core Columns}

Failure of core columns was a result of both spliee conneetion failures and fraeture of the columns themselves. One reeovered core eolumn (WTC 2, eolumn line 801, floors 77-80) may have sustained damage as a direet result of the airplane impaet, however the welded spliee to the column above survived intaet.

\subsubsection{Impact Damage to Sprayed Fire-Resistive Material}

Pre-eollapse photographs indieated that, as expeeted, fire-proofing was removed from piees struck by the incoming aireraft or debris exiting the far side of the buildings. In addition, the impact eaused fire-proofing and aluminum faeade panels to spall off many perimeter eolumns which were not direetly struek, but apparently suffered only strong accelerations and forees otherwise transmitted through the structure. This indireet damage to the sprayed fire-resistive materials (SFRM) was observed on the north and east faces of WTC 2.

A coating on the SFRM prevented the loss of the SFRM in some loeations on the perimeter eolumns. This eoating appears as a band of white features on the SFRM wherever two aluminum panels met on the exterior columns of the buildings, beeoming visible when the panels were dislodged. This may have been a coating applied to proteet the SFRM from moisture infiltration at the aluminum panel joints, aeting to preserve the SFRM even when the SFRM was knoeked off both above and below those loeations.

\subsubsection{Structural Damage - Floor Trusses and Seats}

The damage to truss seats on perimeter panels differed above and below the impaet zone. The majority of perimeter panel floor truss connectors (perimeter seats) below the impaet floors were either missing or bent downwards. Above this level, the failure modes were more randomly distributed. This trend was observed for both towers, presumably resulting from the building eollapse sequenee.

Failure of the welds assoeiated with the perimeter panel floor truss conneetors (perimeter seats) typieally oeeurred as a result of the weld geometry (i.e., in the eomponent with the lowest eross-seetional area) with respeet to the high loading forees of the eollapse. These areas with the lowest cross-sectional area were typically the standoff plates. However, there was no evidenee to indieate that the type of joining method, materials, or welding proeedures were improper.

Of the 31 eore floor truss eonneetors (core seats) reeovered, about 90 pereent were still intaet though extensive damage may have oceurred. Only two were observed to have been completely torn from the ehannel. (This distribution may have resulted from the seleetion proeess at the salvage yards).

In the floor trusses, failure of a large majority of the eleetrie resistance welds at the web-to-ehord eonnections was observed. Failure of the eonneetion between the floor truss and the perimeter panel floor truss connectors was typieally a result of tab plate weld and bolt failure.

In general, the observations eoncerning possible loeal failure meehanisms viewed on the WTC steel from an outside eontraetor were in agreement with those found by NIST. 


\subsubsection{Fire Exposure and Temperatures Reached by the Steel}

The pre-collapse photographic analysis showed that 16 of the 33 exterior panels recovered from WTC 1 were exposed to fire prior to building collapse. None of the nine recovered panels from within the fire floors of WTC 2 were observed to have been directly exposed.

It is difficult or impossible to determine if high-temperature exposure occurred prior to or after the collapse. Of the more than 170 areas examined on 21 exterior panels, only three locations had mudcracking of the paint, indicating that the steel may have reached temperatures in excess of $250{ }^{\circ} \mathrm{C}$. The 21 panels represent only 3 percent of all panels on the fire floors, however, and cannot be considered representative of other columns on these floors.

Annealing studies on recovered steels established the set of time and temperature conditions necessary to alter the steel microstructure. Based on the pre-collapse photographic evidence, the microstructures of steels known to have been exposed to fire were characterized. These microstructures show no evidence of exposure to temperatures above $600{ }^{\circ} \mathrm{C}$ for any significant time for the recovered pieces.

Perimeter columns exposed to fire had a great tendency for local buckling of the inner web; a similar correlation did not exist for weld failure.

Two of the core columns with as-built locations in the fire-affected floors were examined for paint cracking. The few areas with sufficient paint for analysis did not show mud cracking patterns, indicating the columns did not exceed $250^{\circ} \mathrm{C}$. (It must be recognized that the examined locations represent less than about one percent of the core columns located in the fire-exposed region, and thus these temperatures cannot be considered representative of general conditions in the core).

\subsubsection{Time-Dependent Deformation of Perimeter Walls Due to Fire and Load Redistribution}

Images of WTC 1 showed gross deformations of an exterior wall prior to final collapse. Images of the south face of the tower taken approximately $5 \mathrm{~min}$ prior to collapse showed inward bowing of the exterior columns, reaching an observable maximum of about 55 in. near column 316 on the 96 th floor. The inward deflection appears to extend over the entire south face of the building at this time, and is visible between the 94th and 100th floors. Photographs taken approximately $35 \mathrm{~min}$ prior to collapse do not show any inward bowing of the south face of WTC 1 .

Approximately $18 \mathrm{~min}$ after the impact of the aircraft, the east face of WTC 2 exhibited inward bowing of up to $10 \mathrm{in}$. in the region of the 79th to 83 rd floors. This inward bowing increased to $20 \mathrm{in}$. at a time 5 min before collapse of the tower.

Hanging floor slabs at the 82nd and 83rd floors were visible in window openings on the east and north faces, respectively, of WTC 2 and the positions of these slabs changed over time. This suggests a progression of failure of certain parts of the flooring in this area of the tower.

At the moment of collapse of WTC 2, the top portion of the building was found to have moved to the west as it tilted to the southeast. During this tilting, a complex kink developed at the southeast corner of 
the top of the building, in the region of the 106th floor. In addition, the portion of the building above the aircraft impact site twisted slightly clockwise (as vicwed from above) as the collapse progressed.

\subsection{FINDINGS - MECHANICAL PROPERTIES}

\subsubsection{Room Temperature Tensile Properties}

There were over 40 different stecls in the towers, based on the various combinations of suppliers and nominal strengths. Thirty-two steels were sufficiently distinct to require distinct models of constitutive behavior.

The steel used in the construction of the WTC generally met the expectations of the designers and the specifications called for in the stccl contracts. Approximatcly 87 pcrecnt of all tested steel excceded the required minimum yield strengths specified in design documents; approximately 13 percent of test results on the damaged steel did not meet the required minimum yield strengths. The occurrence of test results below the specified minimum values is not unexpected since differences in test procedures from those in the qualifying mill tests could account for 2-3 ksi lower values in the NIST tests, and the loss of a yield point due to damage to the steel accounts for $2-4 \mathrm{ksi}$ lower values in the NIST tests in several cases.

The steels in the perimeter columns met their intended specifications for both chemistry and mechanical properties. The yield strengths of the perimetcr column steels generally exceed their specified minimums by 10 percent to 15 percent. The tensile properties of the perimeter columns are consistent with literature estimates for average properties of construction stcel plate during the WTC construction era. The number of occurrences of plates with tensile properties at or slightly below the spccified minimum is consistent with the historical variability of steel strength.

The steels in the core columns generally met their intended specifications for both chemical and mechanical properties. Some, primarily wide-flange shapes, had NIST-measured strengths that were lower than called for in the specifications, but this may have arisen from mechanical damage that removed the yield point, the natural variability of structural steel, and slight differences between the NIST and original mill test report testing protocols. Regardless of the source, the observed distributions are accounted for in the typical design factor of safety for allowable stress design. However, the yield strengths of undamaged steels in the rolled core columns are lower than the historical literature indicates as typical.

The steels in the floor trusses met their intended specifications. The strength of the steel in the floor trusses is higher than called for in the original specifications. Many of the truss steels that were specified as low strength A 36 were supplied as high-strength, low-alloy steels with much higher strengths. Laclede Steel Company's substitution of $50 \mathrm{ksi}$ yield strength stecl for A 36 in the lower chord of the trusses is expected to have provided significantly improved performance at high temperature.

Limited tests on bolts indicated that they met spccifications. The recovered bolts were stronger than contemporaneous literature would suggest as typical.

Limited tests on recovered welds and wcld material indicated that their mechanical properties and chemistry were consistent with their intended specifications. 
In summary, the steel used in the construction of the WTC towers met the expectations of the designers and the specifications called for in the steel contracts. Material substitutions of higher strength steels were common in the perimeter columns and floor trusses. The safety of the WTC towers on September 11, 2001, was most likely not affected by the fraction of steel that, according to NIST testing, did not meet the required minimum yield strength. The typical factors of safety in allowable stress design can accommodate the measured property variations below the minimum.

\subsubsection{High-Strain-Rate Properties}

The strain rate sensitivity of the perimeter and core column steels was similar to other construction steels of the WTC era.

\subsubsection{Impact Properties}

The impact toughness of steels from the perimeter and core columns, and floor trusses was consistent with literature values for the WTC construction era.

\subsubsection{High-Temperature Properties}

The measured high-temperature yield and tensile strength behavior of WTC steels is similar to behavior of construction steels from the WTC construction era literature.

The creep behavior of WTC steels can be modeled by scaling WTC-era literature data using room temperature tensile strength ratios.

Laclede Steel Company's substitution of 50 ksi yield strength steel for A 36 in the lower chord of the trusses is expected to have provided significantly improved performance at high temperature.

\subsubsection{Conclusions - Mechanical Properties}

In general, the steel used in the construction of the WTC met the expectations of the designers and the specifications called for in the steel contracts.

\section{$9.6 \quad$ ISSUES}

Based on the Investigation findings, NIST identified a detailed set of issues related to practice, standards, and codes that provided the basis for formulating the Investigation's draft recommendations. The Investigation team has studied practices ranging from those used during construction of the towers to newly available practices which could improve the safety and performance of high-rise buildings. The recent development and use of "fire-resistant" steel in Europe and Japan falls in the latter category.

Fire-resistant steels are reported to retain a higher fraction of their room temperature strength at temperatures expected in building fires, and are used either with or without fire protection depending on the application. If fire-resistant steels do indeed retain improved high-temperature properties, then improved fire resistance would be expected even in cases where conventional fire protection has been 
damaged, whether during normal construction and modifieations, or due to intentional damage as in the attaek on the WTC towers.

Each issue identified by NIST was divided into three levels with between two and five categories eaeh:

- Categories in Level 1: praetiees; standards, eodes, and regulations; adoption and enforcemcnt; research and development or requiring further study; and edueation and training.

- Categories in Level 2: all tall buildings (buildings over 20 storics in height); seleeted tall buildings (buildings over 20 stories in height that are at risk due to design, loeation, use, iconie status, eontents, etc.); seleeted other buildings (buildings that are at risk due to design, location, use, historie/iconie status, contents, ete.).

- Categories in Level 3: related to the outeome on September 11, 2001 (i.e., eould have ehanged the outeome); or unrelated to the outeome on September 11, 2001 (i.e., would not have ehanged the outeome yet is an important building and fire safety issue that was identified during the eourse of the Investigation).

Under Level 1, the fire-resistant steel issue is considered to inelude praetiees and researeh and development or requiring further study. The issue, under Level 2, applies to all tall buildings and seleeted other buildings. Under Level 3, the use of fire-resistant steel in the WTC towers may have inereased the time to collapse of the towers.

- Diseussion of this issue is not intended to suggest that fire-resistant steels should have been used in the construetion of the WTC towers, or even that fire-resistant steels were available eommereially at the time of the eonstruetion. 
This page intentionally left blank. 


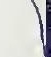

